JAMES HANNAY

His Life and Works

by

George J. Worth

UNIVERSITY OF KANSAS PUBLICATIONS HUMANISTIC STUDIES, NO. 37

LAWRENCE, KANSAS 


\section{2}

University of Kansas Publications

Humanistic Studies, No. 37

\section{James Hannay: His Life and Works}




\title{
James Hannay: His Life and Works
}

\author{
by \\ George J. Worth
}


(C) Copyright 1964 by the University of Kansas Press

L.C.C.C. Number 64-63414 


\section{Preface}

Though each year sees the publication of more and still more books on a few of the major figures of Victorian literature (Dickens, the Brontës, and, lately, George Eliot are examples that come readily to mind), some of the lesser writers of that rich period remain strangely neglected. No one would argue, surely, that the subject of the present volume played a central role in the literary life of his age, but the role he did play has seemed sufficiently important and interesting to make his name and reputation worth redeeming from the obscurity into which they have fallen.

Soon after his death in 1873, two of James Hannay's friends, Annie Thomas Cudlip and Dr. James Steele, projected biographies, neither of which, unfortunately, came off. A number of his other contemporaries, most notably Francis Espinasse, set down accounts of Hannay in their memoirs; but these recollections, usually committed to print many years after the events they record, are fragmentary and tend to be inaccurate. All the modern student of nineteenth century letters is likely to know about Hannay, then, consists of a few scraps of second-hand information in works about other men and perhaps a distorted anecdote or two about his biting wit, his devotion to "blood and culture," and his fondness for strong drink.

This is a pity and an injustice-a situation which this book will try to correct.

My debts of gratitude are many. I could not have written my study without the kind assistance and encouragement, throughout my work, of Mrs. Eleanor Witty of London, James Hannay's granddaughter. She generously made available to me all the materials in her possession pertaining to her grandfather-diaries, letters, and private papers-which were not only highly useful in themselves but which also led me to much other valuable information. For example, though the diaries do not begin till 1852, Hannay sets down in one of his retrospective notes the names of all the ships on which he served while he was in the Royal Navy from 1840 to 1845 . The existence of this list made it possible to consult the Muster Books of those vessels in the Public Record Office; and these and other official records of his service, together with the announcements of ship movements in the 
United Service Magazine and some lucky finds in O'Byrne's Naval Biographical Dictionary (1849), yield a clear and consistent, though regrettably incomplete, picture of his youthful career afloat. Because almost all Hannay's fiction is both naval and autobiographical, the significance of such discoveries, for biography and for criticism, is obvious. I trust, by the way, that I have not fallen into the familiar error of equating a man's fiction with his biography; I have tried, rather, wherever it seemed useful, to indicate what the proper connection between life and literature appeared to be.

I am indebted to the British Museum, the Public Record Office, the Ewart Public Library (Dumfries), the University of Illinois Library, the New York Public Library, the National Library of Scotland, and the Central Public Library (Edinburgh) for permission to consult, and in a very few instances to quote from, their manuscript holdings. Librarians in this country and in Britain have responded with almost heroic patience, kindness, and helpfulness to my many queries and requests for assistance; at the risk of seeming invidious, I should like to single out for special thanks Messrs. George Caldwell and L. E. J. Helyar and Mrs. Joyce MacLeod Quinsey of the University of Kansas Library and Mrs. M. D. McLean of the Ewart Public Library, whose services went far beyond the call of duty.

The University of Kansas has most generously supported my work with research grants, and timely awards from the American Philosophical Society and the Kansas University Endowment Association, as well as a sabbatical leave at full pay from my duties at the University of Kansas, made possible a trip to Great Britain in the spring of 1962 during which I completed my research. For all this help I am deeply grateful.

A number of friends, colleagues, and correspondents, too, have done much to make my work pleasant and to diminish the number of embarrassing errors which this study contains. Some have been good enough to read and comment on portions of the manuscript. Others have assisted in identifying some of Hannay's unsigned contributions to periodicals. I owe special thanks to Mrs. W. M. Ashton of Bradbury, Agnew \& Co., Ltd. and to Messrs. Ronald Freeman, Edward F. Grier, Gordon S. Haight, Walter E. Houghton, Clyde K. Hyder, Leslie A. Marchand, Oscar Maurer, W. D. Paden, Gordon N. 
Ray, Kenneth Shields, John Hazel Smith, Leslie C. Staples, and Robert K. Stone.

My wife has been remarkably good, all these years, about suffering through my numerous attempts to answer the inevitable cocktail party question: "But who is James Hannay?" I hope that the appearance of this book will appropriately reward that forbearance and answer that question. 


\section{Contents}

Preface v

INTRODUCTION: "A MAN OF REMARKABLE GifTs"

I Boyhood and The Navy,

1827-1845

II London: THE EARLy Years, $1845-1850$

III London: THE Successful DECADE, 1850-1860 65

IV Edinburgh: the Courant EDITORSHIP, 1860-1865 124

V London: Decline, 1865-1868 145

VI Barcelona: Exile, 1868-1873 156

$\begin{array}{ll}\text { NOTES } & 168\end{array}$

$\begin{array}{ll}\text { BibliograPhy } & 177\end{array}$

$\begin{array}{ll}\text { INDEX } & 187\end{array}$ 


\section{Abbreviations Used In the TeXT}

$$
\begin{aligned}
& B G-\text { Biscuits and Grog } \\
& C C-\text { A Claret-Cup } \\
& S F \text { - Singleton Fontenoy } \\
& P \text { - "Edgar Allan Poe" } \\
& \text { EC - Eustace Conyers }
\end{aligned}
$$

Page references are to first editions. See Bibliography, pp. 177 and 184. 


\section{Introduction: "A MAN of REMARKABLE GIFTs"}

On the evening of 8 January 1873, James Hannay, the British consul at Barcelona, settled down, as was his habit after the day's official routine had been disposed of, to a piece of literary labor. Sometimes he would work away at an ancient text; at other times, a volume of modern history or biography would engage his attention. He enjoyed rereading the great eighteenth century English novelists, and kept abreast of what was being done in his own age in fiction and poetry at home, in America, and on the Continent. But he was not exclusively a consumer of other men's writing. In his younger days, in London and in Edinburgh, he had been a prolific author himself, and he still wrote lively, graceful, well-informed essays and reviews which he sent back to the Cornhill Magazine and the Pall Mall Gazette. That particular evening he corrected the proofs of an article he had done for the Cornhill on one of his favorite authors, Captain Marryat-an author with whom he had often been compared twenty years earlier, when he had owned a considerable reputation as a novelist of naval life.

Hannay had not been having a good winter. He was hopelessly in debt, at odds with his superiors in the Consular Service, and locked in a struggle with an old adversary-alcohol. When W. H. Wylde, the superintendent of the Consular Service, visited Barcelona on a tour of inspection just after Christmas he was shocked by what he found: Hannay had been drinking heavily, and the files of the consulate were in great disarray. Nevertheless, there was no reason to entertain any unusual fears for Hannay's health, and when he was discovered dead in his chair on the morning of the 9th the shock and surprise were great. Just under forty-six years of age, he had succumbed to a stroke.

The news reached England by telegraph several days later, and the leading papers, most of which were staffed by men who had known him well, were generous in the obituary notices which they devoted to him. Again and again, Hannay was praised as one who might have attained to the greatest distinction: "Mr. Hannay was one of the most brilliant men of letters of his time, though he never did justice to his great powers.... Admirable as his writings are, Mr. Hannay might have produced works which would have rendered his 


\section{JAMES HANNAY}

name not merely famous, as it was, but immortal" (Yorkshire Post). "MR. JAMES HANNAY was, in genius, almost the parallel of THACKERAY, but owing to the necessities of that splendid profession of letters which is a dedication to poverty, he buried himself in a consulship at Barcelona" (Evening Standard). "He was a man of remarkable gifts and of considerable culture. Indeed, his abilities and his acquirements were such that if they had only been wisely employed, and directed with vigour, they must have given him a high place in the history of his day... . There is no man in the House of Commons with anything like his faculty of speech,-nothing of the same kind, nothing which indicates a similar genius. . . C Criticism, indeed, was his strongest role; and if his powers of production had been permitted free play, we venture to think that he would have distanced every Englishman of his time, and have gained for himself the reputation enjoyed by one or two Frenchmen of similar literary character" (Pall Mall Gazette).

Tremendous promise; disappointing achievement; death in semiobscurity and half-exile. He had begun writing for publication as an eighteen-year-old, just out of the Navy; at twenty, he had edited his first magazine; at twenty-one, he had published his first books; two years after that, he had seen his best-known novel classed with Pickwick, Jane Eyre, and Vanity Fair. Still in his early twenties, he had been taken up by Carlyle and Thackeray, both of whom were shrewd enough to detect his weaknesses but nevertheless prophesied great things for him. Before he was thirty-five, he had made a solid reputation as a critic, an editor, and a lecturer on literary subjects. But in his forties he was struggling with a job for which he was unsuited in a foreign city which he hated, and when his life was cut short the temptation to speculate on what might have been must have struck those who knew him as irresistible.

To trace this curiously rich yet sad career will be the object of the following pages. 


\section{Chapter I: BoyHood AND ThE NAvy, 1827-1845}

James Hannay was born on 17 February 1827 in Dumfries, where his father, David, was a widely respected banker. The family was one of the oldest in Scotland, Hannays having been among the powerful chiefs of Galloway who swore fealty to Edward I in $1296 .{ }^{1}$ The main branch, from which James was descended, were the Hannays of Sorbie, in Wigtownshire; the ruins of Sorbie Castle, built in the sixteenth century, still stand.

Though James Hannay was to cherish a lifelong fascination for his family's past, his forebears had long ago put feudal glories behind them. His grandfather, James Hannay of Blairinnie, had been a prosperous landowner and lawyer, who had served as confidential political agent of the seventh Earl of Galloway, but by the time he died in 1820 his financial affairs were badly tangled and it took his son David several years to straighten them out. David Hannay himself was to become the victim of bad luck and poor judgment in 1837 when he got involved with one of the joint stock banking houses springing up in London at that time-one of the many that failed. Until then, however, he enjoyed success and prosperity in Dumfries, first as a lawyer and then as a banker. Like his father, David Hannay was drawn to politics, though, in company with many young men in the 1820's and early 1830 's, he advocated the reform of the institutions which James Hannay of Blairinnie had ardently supported; like his son James, he was a vigorous orator and debater. It was not unnatural, therefore, that David Hannay should contest the seat for the Five Burghs of Dumfries in the parliamentary elections of 1832 and 1835, unsuccessfully both times. "A keen sportsman, an able man of business, and generally popular" (as the Dumfries and Galloway Courier described him years later), David Hannay was also something of a man of letters, though his one published novel, Ned Allen; or the Past Age, did not appear till 1849, when he was fifty-five years old. He had married Elizabeth Affleck, a member of another ancient Scottish family, in 1822.

The Hannays lived at Carlinwark House, just outside Castle Douglas, until 1837, and it was on its grounds overlooking Carlinwark (now Carlingwark) Loch that young James had his first encounter with tragedy. In August 1833, when he was six and a half 


\section{JAMES HANNAY}

years old, his mother set out from home with her three oldest children in a phaeton driven by her husband. Something had been forgotten; intending to go back for it, Mrs. Hannay alighted from the halted carriage just as the horse started with fright and upset the vehicle. She was caught under the wheels and trampled on, and died within the hour-everything happening in the presence of the horrified James, who himself narrowly escaped death, since the seat from which he was thrown "was literally dashed and broken to pieces," as the account in the Dumfries and Galloway Courier put it. "And thus perished," in the words of the same article, "in the prime of life, a beloved spouse, the mother of five fine children, and one who was universally admired and esteemed,-not more for personal loveliness, in which she was almost peerless in the South of Scotland, than for polished manners" (28 August 1833, p. 4). The youngest of the children she left was just over a year old at the time of Elizabeth Hannay's death.

Two years later, a wife being a necessity to a man in his position with five young children to raise, David Hannay married again. The lady he chose was a Miss Harriet Stephenson, daughter of the Reverend John Stephenson, Vicar of Dacre in Cumberland, and she seems to have succeeded admirably in her difficult role of stepmother. To the children she was always "Mamma"; her stepson William, who died as a young man, cared for her enough to leave her his share of his maternal grandfather's inheritance; and a letter she wrote to James (who refers to her with great respect throughout his diary) survives which shows that she regarded her oldest stepson with warm affection. Harriet's management of the household, too, was everything David Hannay could have hoped for; according to family tradition, the remark was made at her husband's bankruptcy proceedings that if the books of his bank had been as scrupulously kept as her domestic accounts it would not have failed.

David Hannay's financial debacle resulted in the loss of his Dumfriesshire and Kircudbrightshire properties and he spent the remaining years of his life in London and at Ridge, near Barnet, in Hertfordshire. He dealt honorably with his creditors, salvaging just enough of his fortune to purchase a modest annuity on which he was able to live comfortably. All the evidence suggests that he was a kind 
and generous, if occasionally imprudent, man; certainly he seems to have been on excellent terms with his son James.

As to James himself, very little can be established with any certainty about the first thirteen years of his life. He received his earliest education at home from a private tutor and at a school in Westmorland kept by an English clergyman; after the family moved to London he was sent to another school, in Surrey.

Then, in 1840, he was entered into the Royal Navy as a volunteer of the first class, apparently with the intention that he would pursue a career in the service in which several members of his mother's family had achieved distinction. The normal course for such a thirteenyear-old lad would have been to absorb a rich dose of seamanship, along with a modicum of required book knowledge, afloat, to pass his midshipman's examination at fifteen and his lieutenant's examination four years later, and then, provided the proper opportunities and political patronage came along, to rise in the naval hierarchy to a solidly respectable position. Seemingly through a direct appeal to the Whig First Lord of the Admiralty, the Earl of Minto, who appears in Hannay's fiction as "Lord Muddle," David Hannay was able to secure for his son an appointment to H.M.S. Cambridge (called "Caliban" in Biscuits and Grog), which was fitting out at Sheerness in the late winter of 1840 prior to sailing for the Mediterranean. Before he could take up this appointment, however, James had to pass a preliminary examination, given aboard the Howe, ${ }^{3}$ which he described years later as "a farce." "You went on board the Guard-ship with your respectable parent or other persons; and full of the natural wonder of boyhood, found yourself in the ward-room. You were then asked to write a sentence or so of your mother-tongue, and if that was achieved respectably, you had 'passed." "4 This ordeal over, he spent his first night afloat on the Vengeur hulk, ${ }^{5}$ and presented himself aboard the line-of-battle ship Cambridge on 2 March.

The Navy which Hannay entered in 1840, as he was fond of pointing out in his fiction and essays, was in a period of transition. To his great regret, hero-admirals like Blake, Nelson, and Collingwood were no more to be found in positions of command, nor were old salts like the seventeenth century Admiral Benbow or the eighteenth century prototypes of Smollett's Commodore Hawser Trunnion any longer fashionable. The service had lost most of its martial rigor and a good 


\section{James Hannay}

deal of its professional pride, and was obviously changing to conform to the requirements of the placid era which the Congress of Vienna had ushered in. What form it would ultimately take no one could say, and in later years Hannay was full of misgivings on this subject;

what was clear was that it could not remain as it was. A Navy led by men like Admiral Sir Edward Owen (whom Hannay again and again lampoons in his fiction as "Sir Booby Booing"), chief commander in the Mediterranean during most of Hannay's period of service there, could not survive either as a fighting force or as the representative and protector of British interests the world over. Hannay's contrast between Owen and one of his particular naval heroes, Admiral Blake, is most revealing:

From Blake dying in his rude cabin in the English Channel-to Booing drawing table-money of 8001. a-year to feed friends-what a change! Of the mere physical changes in the service, in living, and so on, perhaps much complaint should not be made,- forms of living have altered everywhere. But from Blake and his officers, bent on doing God's work on the waters, and with a faith as strong as their oak ships, to Booing, with his belief in the dockyard, and reverence for the powers that are in, -Lieutenant Primby's dandyism, and Captain Praggles' piano,-there has been a change by no means for the better! (SF, III, 146-47)

If twenty-five years of peace had permitted men like Sir Edward to rise to the top, they had had their insidious effect on junior officers as well. A midshipman stationed in the Mediterranean in the 1840's was likely to spend a good deal of his time ashore, drinking and playing billiards in any one of a number of establishments redolent of cigar smoke along the Strada Reale in Valletta, or riding, hunting, going to the races, and pursuing the ladies. Every Mediterranean port contained its large and socially active English colony of commercial, diplomatic, and military gentlemen and their dependents, and English tourists were ubiquitous; the young officer was constantly being drawn into this society. The naval life was no longer lonely, hard, and dangerous, practically divorced from the amenities of English civilization. On the contrary, when he was not cruising, oras happened to Hannay and the Cambridge for a brief period in 1840 -taking part in punitive actions against woefully outclassed foes, the British naval officer, in the Mediterranean at least, was a fashionable man among fashionable people, living at least as well as he would have done at home. 


\section{BOYHOOD AND THE NAVY, 1827-1845}

It did not take young Hannay long to discover that the Royal Navy of the 1840's was far different from the service he had read and heard about and idealized. He learned quickly, for one thing, that the human and physical resources of the Navy were regarded as the playthings of politicians and bureaucrats, at least by certain men in the Admiralty. Not only had his own appointment been secured through political influence, but all his fellow cadets owed their presence aboard the Cambridge to their Whig connections. This earned them the enmity of the Tory mates, men who had long ago passed their lieutenant's examination but were not promoted because the relatively few vacancies that occurred were inevitably filled with Whig aspirants. The result, of course, was perpetual friction and much outright bullying of youngsters in the gunroom $(B G$, p. 15; $S F, \mathrm{I}, 266)$. The mutilated condition of the Cambridge herself was an excellent illustration of how bureaucratic whim could operate to the detriment of the service. "She was properly an 80 gun ship, but by a cunning manoeuvre two guns were removed, and she was thus brought down to the 3 rd rate-which took $£ 100$ per annum off the captain's pay" ( $B G$, p. 5).

If this could be regarded as a personal affront to the Cambridge's captain, a Trafalgar veteran of more than forty years' service named Edward Barnard ("Baggles"), Hannay would have argued that this officer was held of little account by the Admiralty because he did not possess either influence or family prestige. Certainly the fact that the Cambridge, once it had arrived in the Mediterranean, was "sent from port to port, wherever the most work was to be done and the least credit to be got for it" was attributed by Hannay to "the fact that Baggles was a nobody; sprung from no 'lofty lineage,' boasting no connections in the peerage (that bible of blockheads), and no relations at the 'board.' It should have been remembered by the commander-in-chief, that if the escutcheon of the Baggles family was humble, it was at least without a stain; that all his progenitors were decently married in the parish church by banns; and neither sold their consciences nor ruined their tailors" (BG, p. 61). ${ }^{6}$ Although Barnard was a victim of snobbish prejudice, he was not on that account a hero in Hannay's eyes. "He was a man of very narrow intellect, and large personal dimensions; a plethoric antithesis, who thought little, and ate much; a Justice Shallow on the quarterdeck, 


\section{James Hannay}

and a Hercules at the dinner-table" ( $B G$, p. 6). Barnard was entirely innocent of classical learning, and if he belonged to the "Benbow school," this was not so much by virtue of his qualities as a seaman or a fighter as because he eschewed the softening, civilizing qualities which were permeating the naval officer class in Hannay's day.

Even before the Cambridge left England, Hannay was amply exposed to the cumbersome and inefficient way affairs were managed in the service. There was no effective scheme for recruiting seamen in those days, ${ }^{7}$ and as a result the Cambridge was delayed for nearly five months, at Sheerness, Plymouth, and Portsmouth in turn, before even a minimal complement of men could be assembled. ${ }^{8}$ During most of this time, Hannay and the other cadets did little aboard ship because they were unable to do much. Such education as they received they absorbed ashore. While at Sheerness, for example, "I went ashore occasionally with my young comrade, Berkeley, and we made such admirable progress, that, in a few weeks, we were both of us able to discriminate judiciously between the ale at the Fountain, and that at the Ship; we held scientific discourse on the relative merits of Cubas and Havannahs; discussed the pretensions of two rival barmaids (one with dark-the other with blue eyes); and at last were both agreed in opinion that Peppercorn [Parkin, the "second-captain"] was a passionate humbug, and that it was more than probable that Baggles himself was a fool" ( $B G, \mathrm{p} .11)$. The two and a half months at Plymouth, from mid-April to early July, ${ }^{9}$ went off in much the same way; and while there he and some of his shipmates paid an occasional "morning visit to the magistrate which generally ended in our contributing a small amount to the revenue of our country" (BG, p. 22). The town itself Hannay found rather disagreeable: the climate was unpleasant, society clannish, and both vice and eccentric religious sects were powerfully established. At Portsmouth, where the Cambridge spent several weeks in July, she took on supplies and provisions for the British squadron in the Tagus, as well as a diplomat en route to Italy with his entourage..$^{10}$ Since Portsmouth, too, was an exceedingly dull place, ${ }^{11}$ especially to a boy of thirteen anxious to be off on his first voyage, it must have been a great relief to Hannay when the Cambridge weighed anchor at the end of the month, bound for the Mediterranean at last.

Malta, the chief British naval base in the Mediterranean, was the 


\section{BOYHOOD AND THE NAVY, 1827-1845}

Cambridge's destination, but she made several stops on the way. Lisbon, where his ship stayed a week, struck young Hannay as "a splendid and filthy town, which may be compared to a Venus with a dirty face, and by no means deserves so fine a river as the Tagus" (BG, p. 29). The boy was not much more favorably impressed by Gibraltar-"an enormous rock, the top of which is peopled by apes, and the bottom by soldiers"-or Barcelona ( $B G$, pp. 30 and 31).

On arrival at Malta, the Cambridge found orders to proceed at once to the eastern Mediterranean to join the allied fleet commanded by Sir Charles Napier which was waging war against the pasha of Egypt, Mehemet Ali. His deep incursions into the Ottoman empire were threatening the very existence of the Porte and raising the familiar specter of Russian intervention and hegemony in the Middle East. By the time the Cambridge joined Napier's fleet off Beirut, the heavy naval bombardment of the city and the revolt of the Syrians against the tyrannical rule of Mehemet Ali's son Ibrahim had assured allied victory in this engagement. "We, of the Caliban, soon found that we had come too late on the station, and execrated our ill-fortune" (BG, p. 39). But there was still work to be done: Mehemet Ali remained unsubdued. Instead of participating in the spectacular bombardment and capture of Mehemet Ali's bastion at Acre, however, the Cambridge was ordered to join the squadron blockading Alexandria, a considerably more monotonous occupation. One night there was a great flurry of excitement when the Cambridge gave chase to a ship which seemed to be trying to run the blockade. This offending vessel turned out to be the tender of the squadron, whose officer in command had gone to sleep. "We returned-like a dog with his tail between his legs-to our station in the order of sailing, and furnished food for the laughter of the whole fleet next morning at breakfast" ( $B G$, p. 44$)$.

Acre fell; the British, anxious to avoid a threatening conflict with the French, who felt considerable sympathy for Mehemet Ali, came to terms with the pasha and effected a settlement between him and the Turkish sultan. The Syrian war, and Hannay's limited experience of fighting, ended by the beginning of 1841 .

The boy's response to this experience was mixed. There was the exhilaration of participating in a great adventure when the Cambridge lay at anchor off Beirut. There was disappointment at the 
discovery that active service could be dull: nothing is more humdrum than an uneventful blockade. There was horror at the wanton cruelty of warfare, if Percival Plug's reaction, in Biscuits and Grog, to a yarn about an exploit of Captain Lawrence ("Laurie") of the Hastings ("Harold") is not entirely fictional.

"Why, sir, the Harold was lying within gunshot of the shore between Beyrout and Djouni and there was nobody in sight on the beach at all. Up came old Laurie, and ordered half-a-dozen maindeck guns to be got ready. It was done. 'Now send the band on the poop, and make them play a lively air.' That was done also; and the mountaineers, attracted from their shelter by the music-like serpents charmed from their holescame down on the beach. The guns were fired, and they were cut up right and left. Didn't they run!"...

"Not one of all those poor wild mountaineers," said I, "but had some dark-eyed girl to weep for him, most probably. Perhaps had a widowed mother, now lamenting him-desolate in the mountains of Lebanon!" (BG, p. 35)

Ten years later, by the time he wrote Singleton Fontenoy, Hannay was convinced that the whole war had been a ludicrous mistake. Strongly under the influence of Carlyle by 1850, Hannay considered Mehemet Ali "the greatest man the East has produced since Solyman the Magnificent" and held that his enforced surrender to the "effete Government" of the Sublime Porte was a tragedy. "If heroworship be true, it was false, and unless human nature change, it will be regretted" (SF, I, 304). Mehemet Ali had worked wonders in Egypt (he "was a second Nile"); he had brought the tottering Ottoman empire to its knees; but the doctrine of the balance of power had made allied intervention inevitable. "What is this balance of power? It is neutralisation of power! It is a propping up of two swords against each other, making both useless. It is an organized impotence. It keeps the East compulsorily stagnant, by preventing its development through the agency of such men as Mehemet" ( $S F, \mathrm{I}$, 306). To compare this contemptible action, fought on the sites of the Crusaders' battles, with the great and honorable wars of the past seemed to Hannay a mockery. It was

a grand, Common-place Crusade. We had marines eating beef in Sidon, and we inundated Lebanon with second-hand Birmingham muskets. We frightened merchants, destroyed mulberry trees, and killed camels. The 
Syrian war is the most memorable example of the employment of brute force, and the triumph of sheer material strength, that modern times can furnish. A sad want of dignity attends its history. Its operations were complicated by discordant orders, disgraced by petty jealousies between the commanders, and chronicled in dispatches redolent of slang. In a word, we did not conquer the great Pasha, we thrashed him (SF, I, 307).

Fontenoy "made the rocks ring with laughter" at the thought that he too was a crusader. "A crusader in the cause of Downing-street! Hurrah!-down with the Infidel, and up with-what?-the Funds! Up with the Sublime Porte!" (SF, II, 48) The devastating bombardment of Acre made use of modern refinements of warfare undreamed of by its earlier European attackers, men like Baldwin, Guy de Lusignan, and Richard Coeur de Lion. "It was the work of centuries condensed into an afternoon-the spectacle of ruins made in an hour. The poor Egyptians met death everywhere-death from shot-death leaping from their shattered walls-death glancing from their broken guns-death bursting from shells-death from above and below, and around-death in the air-death on the earth. The air was heavy with death! And the perfumed wind from the Syrian shore mixed with the foul smoke, and met death too' (SF, II, 73). The Syrian operation, Hannay wrote in 1850 , "occupies a singular position in history. It has not dignity sufficient for a war, and was too bloody for a farcel" (SF, II, 78)

After this initial period of relative excitement, the rest of Hannay's naval career settled into a fairly routine pattern. ${ }^{12}$ " $\mathrm{By}$ ' 41 ," he recalled eighteen years later, "the Mediterranean station had relapsed into its old, pleasant, gentlemanly, and dissipated dulness."13 From Gibraltar to Beirut the Cambridge and the ships on which Hannay served subsequently plied the Mediterranean waters, putting in at ports of call rich in historic and literary associations and spending much time in Malta harbor.

Hannay always retained vivid and, for the most part, pleasant recollections of that "white island lying set in the blue sea in a region of calm and beautiful air."14 Since Malta was the headquarters of the British Mediterranean fleet, Valletta became a great social and commercial center for naval men. A city of many charms for the young officer in search of diversion and excitement, its most typically Maltese attraction was probably the Strada Reale-"that imposing 
street where the pavement looks so white and hot in the summerwhere the Maltese girls go tripping along with their mantillas flowing-and his Excellency the Cardinal rolls by in a hideously ugly carriage-and military men saunter, and naval men walk, and Turks stroll, and priests glide monotonously in a pace different from all."15

Hannay's frequent visits to the Greek mainland and the islands of the Aegean did much to shape his political, literary, and philosophical views. The squalid state of modern Greece he found a disgrace and a mockery of its noble traditions. Ruled by an incompetent Bavarian king, "governing by rote, and fretting and strutting his hour upon the stage of government, like the king in a Haymarket burlesque" ( $B G$, p. 104), on whom a constitution had been forced by the revolt of 1843 , the semi-barbarous inhabitants were incapable of democracy and unworthy of their glorious past. A letter which the seventeen-year-old Hannay wrote his father from Patras deserves extended quotation to show the acuteness of his observations of the Greek scene and the degree to which his convictions regarding politics and culture had crystallized by this time.

We still remain on this part of the Station showing the flag along the Coast occasionally, as the Elections are going on-The Suffrage in Greece is almost universal, and would satisfy the most exorbitant Sturgeite for this little town inferior a good deal in size, and far \& far in cleanliness, comfort and respectability to Castle Douglas, has 3000 Electors and together with part of the country round about it, returns three members to the Senate... The polling place is a church, electors write their names on pieces of paper and put them in a box, from which they are afterwards taken, and counted, a clumsy way of doing business. ... The other day a man stabbed another in a quarrel, he was a voter on the government side, and they would not even imprison him till they were forced to do so to preserve his life from the relatives of the wounded man. A short time before that, two men in the country to revenge themselves on a farmer, killed his child, and divided it into quarters like a sheep-This is neither an invention nor a delusion of mine but a truth, and a horrible one too-Everything goes on, in the same way-They are fighting openly at Navarino-Men are murdered in coffee-houses frequently murder goes unpunished-robbery even unblamed-the one can be done without danger, the other without reproach-Blackwood talks of the Greeks being fit for a Constitution, but their state is almost barbarous-The boasted-of revolution was not the work of the many, as the many but of the few who wished liberty acting on the many who wanted bread-Their respect or 
fear of the Four Powers prevented bloodshed and scarcely did that-Pooh -Universal suffrage after centuries of Slavery, and years of misgovernment! The fact is this, there is in Greece no public feeling of right or wrong-no crowd would execrate a Greenacre-or attend a meeting to suppress slavery-Religion and Education are neglected or despisedThey have Bishops, priests, \&c who get contributions from the people meat \&c according to what they do, they are paid by the job. It is not Religion that makes them do this-but Superstition which flourishes among them though they differ considerably from Romish faith-The upper classes in Greece are well-educated at an Academy in Athens, headed by a Scotchman, with mostly foreign professors, but this $\mathrm{I}$ hear is going to the dogs since the foreigners are leaving it. As a specimen of the Greek Church "attendite quasi"-A week or two ago, a Greek Bishop dressed in dark garb of silk with Wellington Boots, (romantic eh?) holding in his hand a wand with golden top, like Prospero's or an English footmans, came on board with several others to see the Ship-As I respect religion and venerate learning I went to him and began to treat him with civility-Could he speak French I asked? no- (I dont speak Italian, myself) Latin? Yes. I made one or two remarks in Latin which I know pretty thoroughly now, as I carry Cicero in my pocket, and can read him as easy as I can the Chronicle-He bowed, I took him to the berth, and showed him a Horace, after looking at it, through his spectacles he pointed to it and said interrogatively "Inglese?" Fancy my disgust. No wonder he only bowed when I spoke to him! and the language of Cicero was thrown away on a Goth! Orem acerbam! To conclude-Greece is in a horrible state-No divisions of property, no respect for persons-no law, no honour, no feelings, drunkenness, poverty, misery, and crime, and what crime? The country here is mostly sown with currants which are now ripening. By way of preserving them from robbers what do they do? Every mile or so of the currant grounds little huts of straw are hoisted up on poles, in which, day and night, watchers sit with guns to shoot those who approach. Scaremen, they may be called-Greece is indeed "a nation meted out and scattered whose land the rivers have spoiled"! 16

(To remind us that this incipient journalist is still a naval cadet in his teens there is a postscript: "If I am compelled to draw a small bill on you before the time, recollect that it will be for something necessary.")

He compared the modern inhabitants of Athens, living as they did against the backdrop of the ruins of antiquity, to gypsy squatters at Stonehenge: "The contrast is just about as great; and the relation 


\section{JAMES HANNAY}

of modern to ancient there quite as respectable."17 The capital itself was exceedingly depressing. "There is a sort of tawdry semi-Turkish semi-French seediness about those narrow streets which inspires one with profound melancholy and disgust. There is a muddy palm-tree growing at the entrance of the main street in a consumptive manner, -a false life like the life round about. And there stand for ever and ever, brown and ghostly the temples of the old time, beside which this said life with its noise, falsity, and pettiness, goes bustling on: a kind of wake that life seems round the noble death there-a wretched wake over a dead queen."18

Wherever in the Mediterranean British ships sailed, there were always Englishmen to welcome their officers when they went ashore. Increasing acquaintance with these consuls, merchants, and other exiles inspired mixed emotions in Hannay, and his reflections on their bittersweet existence are especially interesting in view of the fact that he was to end his own days in much the same manner in Barcelona thirty years later. A benign climate, luxuriant scenery, an abundance of food and drink which can be obtained only with difficulty and at considerable expense in England: a life, in short, of ease and comfort-should this not entice the Englishman away from "the 'fog-Babylon,' taxes, and the influenza"? (BG, p. 65) But weigh these benefits of Mediterranean life against "political degradation, popular ignorance, and diseases that there is no science to check, and who does not prefer the north?" (CC, p. 50) Singleton Fontenoy has a chance to marry a beautiful young lady whose father is the British consul on an island in the Aegean. "He could go with them to Enupnion,-become Vice-Consul,-grow mulberry trees, and feed silkworms! It would be a beautiful exile-but to live amidst such people-to dwell in a land where new magazines never reached, and Hansard was unknown! He was too English for that!" (SF, II, 282. 83).

Hannay's life during these years, of course, was not all sightseeing and philosophizing. His naval career still occupied most of his timeand it was not without its tribulations, which increased as his period of service went on. Two years after joining the Navy, he passed his midshipman's examination and was promoted on 28 March 1842 in the normal way. ${ }^{19}$ That autumn, on 18 October, he was discharged to the Snake under circumstances which remain somewhat obscure; 
there seems, however, to have been no stigma attached to the transfer..$^{20}$

The Snake (which appears in Biscuits and Grog as the "Snob," in Singleton Fontenoy as the "Viper," and in Eustace Conyers as the "Lotus") was a graceful sixteen-gun brig designed by Sir William Symonds, a naval architect on whose work Hannay bestowed lyrical praise on every possible occasion in later life..$^{21} \mathrm{~A}$ number of factors combined to make his year's stay on the Snake more enjoyable than his sojourn aboard any other ship on which he served. There was, first of all, the "dreamlike, moonlit, oriental" beauty of the brig herself (EC, II, 38-39). Then too, as a small vessel the Snake was "more free and easy in regard to discipline, and besides, a small vessel in the Mediterranean moves about a great deal, and sees the best and most curious parts of the station" ( $B G$, p. 77). Finally, for the only time during his years in the Navy, Hannay served on the Snake under a captain whom he wholeheartedly admired, Walter Devereux ("Delamere" in Biscuits and Grog, "Montfichet" in Eustace Conyers). As an alert and sensitive student of human nature, a budding disciple of Carlyle, and a fervent believer in the worth of ancient and honorable pedigrees, Hannay found much to venerate in his captain. Second surviving son of the fourteenth Viscount Hereford, Devereux, unlike the modern upstarts with bogus pedigrees whom Hannay constantly ridiculed, belonged to a very old and noble family. He was a man of imposing physical appearance and reserved mien who exerted a firm but kindly control over his officers and men. Because he possessed the personality and authority of a true leader, and because both he and those under him knew it, Devereux did not need to play the capricious martinet and governed "less by discipline than tact, managing the ship more as the president of a republic than the despot of an empire" ( $B G$, p. 77). As Hannay pictured him in Eustace Conyers, Captain Devereux was a disappointed man with "a hereditary claim to be a great personage" who deserved better of the world and his country than an obscure naval command; yet he never voiced his grievances and did his duty with scrupulous fidelity ( $E C, \mathrm{II}, 42)$.

A marked contrast to Devereux was his first lieutenant, Henry Hire ("Hireling"), a stupid bully with whom Hannay seems to have had many skirmishes. "Our simious friend soon perceived that I was 


\section{JaMES HaNnAy}

not one of his sort; I am certain that he hated me for being a reading man to begin with, (he was himself more ignorant than a hound)and that he had a certain misgiving that I held him in profound contempt." ${ }^{22}$ The psychological wounds which Lieutenant Hire inflicted on the young midshipman must have been deep indeed: as long as a quarter-century later Hannay remembered him as "a great Naval Cad of the old school." "He ran about, barking at the men like a sheepdog, when work was going on, in language that would have caused a riot at Wapping. He pelted the men on the yards with filthy words; and, when exhausted, would refresh himself by caning a ship's boy with the master-at-arms' cane." ${ }^{23}$

Never again was Hannay to be as fortunate in his ship or his captain. His fiction does not tell us much about the Orestes, aboard which he served from October 1843 to July $1844,{ }^{24}$ or her captain, Edward St. Leger Cannon ("Gunne" of the "Orson"); in A ClaretCup the captain is described only as a uxorious incompetent who "knows no seamanship; nor has he one human accomplishment, except being able to mix a good salad" (CC, p. 32). It was by order of Cannon that Hannay was disrated to naval cadet while on the Orestes: his captain found him guilty of "insolence, insubordination, repeated negligence, inattention and disobedience of orders." ${ }^{25}$ This was not the last time that such charges were to be leveled against Hannay. Clearly, his naval fortunes began their decline during his service on the Orestes.

This decline continued on his next, and last active, berth, aboard the Formidable, Admiral Owen's flagship, which was commanded by Captain George Frederick Rich. (Rich is "Ricks" in Hannay's novels and stories, and the Formidable appears as the "Preposterous" and the "Cleopatra.") Life aboard the Formidable, which was anchored off Malta, was anything but arduous.

The hands were turned up to drill by daylight, when the midshipmen, in blanket trowsers and otherwise gay deshabille, ran about actively enough, -the watches were slept through with praiseworthy regularity, -general quarters were occasionally indulged in, when a newly-invented trumpet for summoning the boarders caused much fun, noise, and confusion. During the ship's company's dinner time, it was found necessary to partake of ices, which an old Frenchman brought off in a curious machine, nice and cool; plum-cake is not a very absurd concomitant of 
lemon ice-and after both, a cigar is refreshing. Besides, the gunroom mess did not dine till six, when they partook of some dozen of made dishes, \&cc., served in a really respectable style, upon china, adorned with the mess arms (a donkey rampant), and accompanied by iced wine. To live near the shore of a populous island without landing there, is at least tedious, which was probably the reason why the gentlemen of the "Cleopatra" were constantly landing ( $S F$, III, 148-49).

Under the circumstances, with little or no active duty to serve as a safety valve, it was probably inevitable that a hotheaded young cadet, in all likelihood still smarting from his treatment aboard his last ship, would soon run afoul of his captain, especially such a captain as Rich seems to have been. As Hannay (surely not a disinterested judge) described him, he was a hypocritical bully given to flogging his men with great relish. ${ }^{26}$

In a serialized story written in 1852, one of Hannay's spirited young fictional midshipmen, Herbert Flower, tongue-lashes a very similar captain, Bilboes of the Intolerable, after Bilboes has rebuked him for rowdiness: "Come sir, you are talking like a tyrant! You are a tyrant, with the heart of a flunkey, and the manners of a boor! You delight to inflict petty annoyances on the gentlemen whom accident has put under your power." Speechless with rage, Bilboes sends Flower off to Sir Booby Booing to be disciplined, which does not much discompose the exceedingly cool Flower. "A youth who has health, pluck, and hope, and loves his intellectual independence, feels no particular awe of an imbecile old gent. in a seedy blue coat; and Herbert Flower's interview with Sir B. B.-to whom he was introduced with awful ceremonies by flunkeys and flag-lieutenantsleft no permanent impression on his mind. (I have heard him regret that the admiral was not more particular in his toilette.) The upshot was, that Mr. Herbert Flower was discharged to the Kabob to await a passage to England...."27 Obviously there is a good deal of wishfulfillment mixed in with the autobiographical elements of this narrative, but known fact and reasonable inference suggest that the relationship between Hannay, Captain Rich, and Admiral Owen must have been very much like that between Herbert Flower, Captain Bilboes, and Admiral Booing. At any rate, the muster book of the Formidable records Hannay's dismissal from the service on 22 April 


\section{JAMES HANNAY}

1845 and his discharge to the Ceylon (which appears as the "Kabob" in a number of his stories) to wait for transport to England.

Although Hannay was now technically a "supernumerary," it was during his two months on the Ceylon, in Malta's Dockyard Creek all this time, that the ludicrous and yet dismal climax of his naval career occurred. As Hannay told his side of the case in a semi-autobiographical story called "The Court-Martial," the commanding officer of the Ceylon, Lieutenant Roger Curtis ("John Lumper") bore him a grudge from the very beginning of their association. Curtis was a man of little ability and less integrity who had attained his rank largely through the intervention of his father, Rear Admiral Sir Lucius Curtis, Admiral Owen's second in command and superintendent of the naval establishment at Malta. There was between young Lumper and Maxwell Adair, the hero of the story, ${ }^{28}$ the antagonism so familiar in Hannay's fiction between the ignorant boor and the man of culture and breeding. Hannay's reputation for independence and "insubordination" (which he defines in Singleton Fontenoy [III, 253] as "a disposition to resent offensive insolence from a harsh superior") had preceded him to the Ceylon and Curtis hoped to advance his own career by showing his superiors how effectively he could deal with such a troublesome character, "and by finally keeping his eye on Mr. Adair, to get for himself no end of laurels:-and plenty, too, he needed, if he wished in crowning himself to hide his ears!" First of all, Curtis "stopped my leave, though there was no charge against me, and I had been discharged to the 'Kabob' at my own request. There was no duty to do; I spent most of my time in reading; and as there were two or three other fellows waiting passages, I was contented enough." ${ }^{29}$ Then, determined to bring his victim to the supreme disgrace of a court-martial, Lieutenant Curtis began to collect evidence of his misbehavior, which he was able to do by systematically exaggerating and distorting the significance of the perfectly normal actions of a high-spirited young man kept in virtual confinement and enforced idleness. And Hannay obviously did not help his case by protesting to Admiral Curtis about his son's treatment of the supernumeraries aboard the Ceylon..$^{30}$

By 12 June 1845 Lieutenant Curtis had his wish: Hannay, along with two partners in alleged crime, was brought before a court-martial aboard the Formidable, presided over by Admiral Curtis himself, 
"who, of course, was just the man to judge equitably of a case brought forward by his son and heir." The court-martial furnished young Curtis with a great opportunity for self-glorification. "Nobody ... could be more unimportant than Lieutenant John Lumper in ordinary life; but Lieutenant John Lumper going on board in full uniform, as a 'prosecutor,' in a cocked-hat, was rather a formidable object. He looked two inches higher, and not much stupider, perched behind the chair of the president..." The whole occasion was marked by a self-conscious and strained dignity.

There is an inexhaustible delight to pompous and feeble intellects in ceremonial; and here is an affair full of ceremonial. . . . All very imposing, as far as the soldiers, cocked-hats, and noise go; and nothing unimpressive-except the men. By-and-by, as civilization proceeds, I make no doubt that courts-martial will be held by the cocked-hats only! and I throw out the suggestion, in this economical age, as likely to save expense. . . I I suppose there is some moral want in my composition; but I was a great deal less awed by all this, though I was only a youth of eighteen, than anybody might expect, and just as alive to the absurd and ludicrous pomposity of the affair, as I am at this moment. ${ }^{31}$

Hannay and his co-defendants, two supernumeraries named Cramer and Parker, were accused of having

conducted themselves with great impropriety on various occasions and more particularly,

$1^{\text {st }}$ In refusing payment to the Messman for articles supplied them in their mess according to an agreement made in that behalf.

$2^{\text {nd }}$ For having been guilty of rioting in the Middle Watch one night about a fortnight since and attempting at the same time to force the door and break into the Messman's Cabin, in which a quantity of wine and Porter was kept.

$3^{\text {rd }}$ That the said $\mathrm{M}^{\mathrm{r}}$ James Hannay had riotously beaten $\mathrm{M}^{\mathrm{r}}$ Peter $\mathrm{P}$. Parker late clerk of the Amazon, likewise a supernumerary in the Ceylon, the latter having come on board in a state of inebriety late in the evening of Sunday the $8^{\text {th }}$ of June.... $3^{32}$

With regard to the first charge, Hannay's cross-examination of the somewhat bewildered Maltese steward whom he was supposed to have cheated brought out that the messman had "no fault whatever to find" with his "conduct to him in money matters. Next, I draw out that he had been asked about the matter-had not voluntarily com- 


\section{James Hannay}

plained; which makes Mr. John Lumper look a little more foolish than usual." 33 In fairness to the members of the court-martial it should be pointed out that this charge was declared "not proved" against Hannay. ${ }^{34}$

The Ceylon's simple-minded gunner, Lieutenant Curtis' staunch ally, stated the prosecution's case on the second charge. He "deposes to some noise in the ward-room. (This, you observe, is the rioting.) He deposes to a key being put to a door. (This is the breaking-open.) $\mathrm{He}$ is asked his 'general opinion' about our character and conduct; for John Lumper feels he has us there, if his friend Gobb be allowed to expatiate on his 'general opinion.' Gobb mutters something about our 'lying in bed in the morning,' and then affirms that he has but a bad opinion of us altogether. Fancy asking a pot-boy's opinion of the character of one of the strangers at his hotel, and you have a notion of the value of Gobb's one." 35

And the third charge, according to Hannay, was an absurd and malicious distortion of a friendly scuffle in which he had engaged with a tipsy shipmate..$^{36}$

Hannay refused to throw himself on the mercy of the court, as he was advised to do, and conducted his own defense with vigorous cocksureness. First of all, the eighteen-year-old pointed out to the distinguished officers sitting in judgment on him, the whole trial was illegal: "The articles of war provide, I urged, for persons on 'active service and full pay.' I could not be so described while in the 'Ceylon' waiting a passage." After this initial objection, he "argued and ridiculed the charges away in turns." 37 As he had fully expected, however, all his oratory was to no avail. He was found guilty on the second and third charges and adjudged "to be discharged from Her Majesty's Service with disgrace and considered incapable of further serving Her Majesty Her Heirs or Successors." 38 This sonorous verdict did not in the least disconcert the young man. "I emerged into the beautiful air of the Mediterranean summer, as calm and cheerful as I ever was in my life! Thanks to my 'notes' [taken by Adair during the proceedings], the report of the trial went abroad, and the charges and sentence excited the ridicule of the whole profession in both hemispheres, and were laughed at from the North Sea to the Indian Ocean."39

Hannay's argument as to the illegality of the trial was no auda- 
cious bluff on his part. His and Cramer's sentences were ultimately reversed: "as they were not on full pay at the time they were tried it was illegal \& the sentence is null \& they are to be deemed in every respect in the position they were in before the trial viz. discharged for bad conduct. Acqt Adm. L Curtis with this decision \& he is to guard against the recurrence of such a case." 40 Nevertheless, "no amende, no apology, no reinstatement followed upon this decision of the Crown lawyers. Stultified in its intentions, and neutralized in its results, laughed at in the profession itself, and repudiated by the law of the land, the Court yet, we see, had a partial success." ${ }^{11}$

Hannay and his two fellow defendants were sent as far as Gibraltar on the Fantome (the "Sprite" in "Mr. Adair's Narrative"), but they had not yet passed out of the range of old Admiral Owen's vindictiveness. "The moment we joined her, we were informed, that, by special orders from Sir Booby Booing, Knight, Commander of the Tub, Grey-Goose of Hanover, we were not to be allowed to mess with the officers. That is to say, that, having been tried for a breach of military and technical laws, we were to be treated as if we had been found guilty of stealing spoons, cheating at cards, or some offence of that complexion." 42 At Gibraltar they were transferred to the Scout ("Sandpiper"), which arrived in Portsmouth on 27 July 1845. Hannay was discharged the next day, ashore in England for the first time in almost exactly five years. ${ }^{43}$

One way in which Hannay's service in the Royal Navy was useful to him is apparent from the number of quotations in the preceding pages. His naval experience furnished him with the raw material for all of his fiction, material which he transmuted in ways to be discussed later. In many of his best articles and reviews, too, he drew on the rich knowledge of seafaring in general and the Royal Navy in particular which he had acquired while afloat. But these years had other, less tangible but certainly not less important, effects on Hannay.

All his most cherished notions-about the dangerous inequities of the nineteenth century English class structure, the importance of firm leadership by men of impeccable breeding and unquestioned ability, the great value of the intellectual life-all these notions, as well as a certain impatient contempt for those who did not share them, were nurtured during these years. Sham leaders and political 
opportunists, he found, were rising to the top in every sphere of English society after the so-called reforms of 1832, and the Navy was profoundly affected by the increasing venality of public life. With an incompetent politician like "Muddle" as First Lord, it was small wonder that, as the veterans of the "Benbow school" used to mutter in disgust, "the service is not what it was." Abuses of all kinds flourished. Nepotism was rampant and it was fitting that "Muddle" himself should set an example as a particularly expert practitioner of this art: "He seemed to have an impression that the duty of a first lord was to fill the navy with his connexions and dependants. And it must be admitted that nobly he discharged that duty-persevering like a martyr in providing for his relatives, even at the expense of his reputation for honesty" ( $B G$, p. 4). According to Hannay, "The Family-Ship," as he called one of his stories, was "a very well-known naval phrase." In such a ship, all the officers were somehow related to each other. "Why, my dear Sir, the first Lieutenant's the Captain's cousin, and the assistant-surgeon's the first Lieutenant's brother-inlaw; and the second Lieutenant's aunt married the Captain's uncle; and two of the youngsters are the Captain's nephews! Then-let me see-the Purser comes in somehow. Ah!-the Purser's mother's maiden-name was Hackles. Yet, that's it! he's somehow related to the first Lieutenant." 44 As we have already seen, political kinship was also a frequent factor in appointments and promotions. A notorious case in point, whom Hannay mentions on a number of occasions in his fiction, is "Captain Kraggles, M.P.," commander of the "Dragon." $\mathrm{He}$ "stood with an oratorical air on his paddle-box, for he was a statesman on board ship, and a sailor in Parliament-as far, at least, as he was capable of being either, anywhere. The ministry, whose property he was, used him at home, or abroad, according to their convenience. 'A cap by night, a stocking all the day,' might have made his motto!" 45

Such buffoons were not true leaders, and as a result they could not impose their will on the men under them. Sailors, Hannay always felt, were exceptionally shrewd judges of human nature, and they were loath to do the bidding of quacks. ${ }^{46}$ Small wonder, then, that ships were inefficiently run. Hannay considered the prevalence of flogging, which he deplored, and other forms of senseless violence aboard ship as outgrowths of the impotent leadership of the modern Navy. A hero-admiral like Collingwood "maintained his ship in the 
most admirable order without a tithe of the flogging now carried on in any average vessel. And this was nearly half a century ago! What makes the difference? The difference is in the commanders! It is a known fact, that some officers can dispense with the lash altogether. The thing then can be done. Why is it not so, universally? Because the selection of officers is bad; because the education of officers is bad; because, if a man finds himself allowed to govern men as beasts, he will not take the trouble to try and govern them in any other way" (SF, I, 283-84).

The Navy was not the only segment of English society in which Hannay was able to observe the effects of increasing social mobility and democratization during these years. In his Mediterranean travels he saw a good deal of the boorish and ignorant English tourist, about whose twentieth century American counterpart we have been hearing so much. To Hannay, these travelers represented all that was worst about the great noveau riche class which the Industrial Revolution had spawned, and their odious existence brought him to some melancholy reflections about the new English social structure. Biscuits and Grog contains a long and devastating catalog of the various species of English tourists in the Mediterranean. Of all these, that which perhaps most aroused Hannay's ire was

the retired tradesman class, who, all the time they are abroad, are not only, virtually in England, but in a shop, or a villa, near London. When they meet you at a table d'hote, they express their joy to "see an Englishman once more," as if they were in the Desert of Sahara. They grumble at the bills, and the bedrooms, and think "that after all, there's no place like home." They live in the closest, most densely-furnished rooms they can get, which they say "are in the good old comfortable English style." They order up huge tea-pots of tea, at the same hour as they did when in Clapham, on system, but take a little brandy in it, "just because they're abroad." They walk up Vesuvius-the father with a cotton umbrellathe mother in pattens. The son John (whom they have great difficulty in keeping in order) goes about the town to see if there's no place like Evans's, where he can have a lark. On their return to England, they only remember that it was very hot abroad (BG, pp. 109-10).

Not much, if at all, better were the wealthy

yacht-travellers, who journey in large cutters, and schooners, with enormous quantities of luggage, fat men-servants, pretty nursery-maids, and 
chubby children. Their yachts are crammed as full of materials for a voyage as Noah's Ark. They travel partly to escape ennui, and partly because it is "proper" to do so. They bring hosts of introductions, to unfortunate ambassadors, and condemn everything that does not resemble what they saw in England. They live in the most expensive manner, in the finest hotels, which, however, they look down upon. They receive you in the most splendid style of luxury, but apologise for it, and remind you "that they are not in London now." If they encounter a foul wind, they run into the nearest port. They go mechanically to see antiquities, but are too dignified to be enthusiastic. They patronise the Parthenon, and say that "it's a pity it's in such a ruinous condition." They smile approvingly on the finest Claudes, in the gallery in the Bourbon Museum, at Naples; and think it "proper" to look very solemn at the Holy Sepulchre in Jerusalem. In short, though they should travel a thousand miles, they are never out of England-a characteristic of very many travellers of all ranks. They look at nature through an opera glass. Sometimes they write large books of travels, in which they try to be very fine in describing storms. .. . They take care also to tell you in their quartos what they had for dinner, and how much they enjoyed the society of Lord X, the Marquis of Y, and Baron Z (BG, 107-09).

Such people insisted on judging everything they saw by their narrow standards. Mr. Snigsby, a "retired tradesman," who is the type of the parvenu tourist in Hannay's fiction, recorded in his journal his view of Socrates, after a visit to the philosopher's prison and tomb: "Great man; opposed popular superstitions. Resemblance of to passers of Reform Bill."47 Snigsby naturally applauded the Greek revolution of 1843 , by which King Otto was forced to accept a constitution, as a sign of progress. "It was pleasant to him to see the regular old political business going forward in the old way. The king not being fit for a king, why, of course, he must have one or two more imbecile people to help him, and so everything would come right." 48 Everywhere these cockney tourists went (for Hannay, the term "cockney" was a good deal more inclusive than its usual meaning), they left traces of their enlightened presence: either in the form of autographs scrawled over the most hallowed monuments, or of inane sentiments inscribed into the guestbooks of hotels and inns. "What possible use can it be to a civilized creature to be made aware of the fact that 'Mr. Tomkins, of Clapham, had a good night's sleep here,' or that 'Mrs. Buggins' fowls worn't cooked properly?' " (BG, p. 65) 
If Muddle, Booing, and Snigsby, all incompetents or fools who had achieved great success in their respective professions, represented the best men England could produce in the political, military, and commercial spheres, the nation was indeed in dire straits.

Two other ways in which Hannay was permanently affected by his naval career remain to be recorded. First, there seems little doubt that his lifelong habits of assiduous reading and study were formed afloat. In the letter to his father from Patras from which I quoted earlier, Hannay mentions his familiarity with Latin as well as his study of "Languages, politics, and oratory." 49 Again and again he represents his fictional alter egos as immersed in a classical author in the long hours off duty, and he frequently refers to the great educational benefits of shipboard life.

The long watches below, the solitude of a cabin, even the quieter hours of a berth or gunroom, admit of ample converse with the books; and the hours quietly spent on deck in the presence, at once soothing and solemn, of the grand old sea itself, are equally encouraging to him who would digest and assimilate what books teach. But this is not all. A naval officer enjoys many other advantages favourable to his intellectual culture. $\mathrm{He}$ visits some of the most important and attractive cities of the world. $\mathrm{He}$ has access to the people best worth knowing in them all. ... Nothing but the stupidest misinterpretation of traditions can make out such a career to be anything but essentially intellectual, and worthy of all the culture and the grace which can be brought to it by the widest literary resources. ${ }^{50}$

Such naval heroes of his as Blake, Nelson, and Collingwood, Hannay was never tired of pointing out, were scholars as well as seamen and had ample time to indulgc their literary inclinations while at sea.

Less clear, but nevertheless clear enough, is the impression one gains from Hannay's writing that the alcoholism which was to cause him such acute distress had its beginnings during his years in the Navy. For the most part, the many gunroom drinking bouts which he records in his fiction seem to have been harmless enough affairs, in which sprightly wit was prominent and sottishness nowhere in evidence, but occasionally a darker note surprisingly creeps in. In Eustace Conyers a brother officer points out to the young protagonist the dangers of service in the Mediterranean: " 'It's the ruin of young fellows. It is still as it was in Homer's time. ... Why, the syrens are natives of it, and the lazy lotus-eaters; and the man-eating 


\section{JAMES HANNAY}

cannibal, the dun, is found there; and on its pleasant shores the satyr capers, and the drunken Silenus has his face daubed with mulberry stains,-which don't wash out always ..." (EC, I, 231-32). Or, later in the same novel, there is this observation:

Raleigh, sent off to the Mediterranean, as a youngster, in a line-of-battle ship, with nothing at hand to do, but routine, and temptation everywhere about, and such leaders to look up to, as some that we knowwould find, great as he might be, not such nutriment for his genius as he did find in the days in which God placed him. True, the individual is all but everything; true, it is cowardly of us to sit down and blame our "circumstances," when Heaven has given us free-will-the same access to its throne which our fathers had-and the inspiration of an heroic history. Yet we must, in common honesty, allow for men's conditions and circumstances; and admit that, if these are unfavourable, men have a right to plead them, in bar of too heavy a sentence. Idleness, increased luxury, the very horror of ennui which belongs to strong natures-these have tempted many a man, naturally good, into what sweet Ophelia calls, "the primrose path of dalliance." If a man has never been so tempted, let him thank God for it (EC, III, 28-29).

Written when "temptation" had become much more familiar to Hannay, these passages speak eloquently for themselves and their author. 


\section{Chapter II: London: THE EARLy YeARS, 1845-1850}

On his return to England in the summer of 1845, Hannay settled in London, where his father and stepmother were then living in the Mornington Road, St. Pancras. Having been disappointed at sea, he determined, like so many other young men, to make his way in the capital, and he succeeded better than most. During his first five years there he rose from obscurity as a young reporter, a contributor to short-lived comic magazines, and a denizen of Bohemia to a kind of renown as the author of sprightly novels of naval life whose work had attracted the favorable attention of Thackeray and Carlyle. But his rise was not an easy one, and his stint in Grub Street left permanent traces.

It was through his father's friend John Ramsay McCulloch, the Scottish political economist, that he secured his first journalistic employment, on the Morning Chronicle. That paper had once been the great Liberal rival of the Times, but by the time Hannay joined its staff in 1846 its prestige and prosperity had seriously diminished. ${ }^{1}$ It seems impossible to discover very much about his work on the Morning Chronicle: his diary tells us only that he "reported the Railway Department" during most of 1846 and that he was with the paper "from spring to autumn" of 1847. Reminiscing about Hannay nearly half a century later, Henry Vizetelly wrote that he "had parted with the proprietors of that moribund 'daily' on the reverse of friendly terms," 2 and it is a fact that, soon after he left its staff, Hannay attacked the Morning Chronicle ruthlessly in the pages of Pasquin, a penny comic magazine which he founded in 1847 with Henry Sutherland Edwards. With the impudence that was to be characteristic of much of his work as a young journalist, he relentlessly scoffed at the poverty-spiritual and intellectual as well as material-of his former employers and their increasingly unsuccessful attempts to compete with their recently founded Liberal rival, the Daily News.

"At this period," Hannay wrote some years later about the time which saw the birth of Pasquin, "the British public was rabid for comic literature. To do the B.P. justice, it is always willing to be amused, and liberal to its buffoons. But in those days it bought funny journals and little books with voracity; and funny journals and little books were showered on it accordingly.... And, once for 
all, the thing was thoroughly done: Every popular verse in the English language was parodied. Every familiar phrase was twisted into all the varieties of meaning possible. It was only with difficulty that some fellows were kept off the Book of Job."'3 The two young men-Hannay was only twenty and Edwards nineteen-attacked practically everything and everyone in sight in the public life of London in the pages of their "Satirical, Political, Critical, Theatrical, Whimsical, and Quizzical Chronicle." Chief among their targets, perhaps, were Punch, the acknowledged leader in the field, with which they obviously regarded their magazine as competing, and another of Punch's rivals, The Man in the Moon, started earlier in the same year, 1847, by Albert Smith and Angus B. Reach. The Man in the Moon regularly charged that most of the jokes in Punch were not funny and that those which were had been borrowed without acknowledgment from various sources. Pasquin hurled these same accusations at Punch, but claimed that The Man in the Moon was equally guilty of misdemeanors and that Punch itself was among its victims.

More often than not, Pasquin's attacks against its competitors were bitterly personal. Singled out for special abuse were Douglas Jerrold, one of Punch's most important contributors, and Smith and Reach, co-editors of The Man in the Moon. Hannay repeatedly ridiculed Jerrold as an ill-tempered, ill-bred democrat. ${ }^{4}$ In the second number of Pasquin, for instance, he was crowned "King of the Cockneys" to succeed Leigh Hunt, who was "attached to better things now." Jerrold supposedly owed his triumphant success over his rivals to an election address in which he pointed out his unique qualifications:

He defies any one to point out a quotation from Plato, Cicero, Bacon, or any old celebrated author in his works. He has laboured to prove that poor men are necessarily good, while the rich are of course bad: and that there is a deadly hatred between the rich and the poor, which he has done his best to increase. He was always a philanthropist, and has accordingly endeavoured, as far as it was in his power, to make everybody discontented with everything. He defies any one to point out anything like a useful suggestion or a mere kindly thought in his works. $\mathrm{He}$ thinks the present the most enlightened age ever known, and himself the most enlightened man in it (21 August 1847, p. 10). 
Jerrold was also attacked somewhat less directly through one of his favorite brain children, a club for working class Londoners appropriately named the Whittington. Hannay on numerous occasions expressed his scorn and indignation at the thought that the boorish clerks who belonged to the Whittington Club fancied themselves on a par with the members of the august establishments along St. James's Street and Pall Mall. Faring even worse than Jerrold was his fellow-radical and associate in the Whittington Club scheme, William Howitt, then editing Howitt's Journal. According to Pasquin, Howitt was a "mean and miserable" philanthropist, possessing "Jerrold's faults without his intellect," who lent his name to the Whittington cause merely to "puff" his own reputation (28 August 1847, p. 19). "Good News for the Readers of Howitt," Pasquin proclaimed at the head of one of its satiric paragraphs: "We perceive, by an article in Chambers' Journal, that attention is being paid to the education of Idiots" (18 September 1847, p. 44).

There are a few scattered instances of serious, temperate literary criticism in the columns of Pasquin. Dickens, for one, did not fare very well there. Dombey and Son, which was then appearing in monthly parts, seemed to one of the participants in the "Noctes Pasquinianae. No. 1" (the only number to appear: this was in the last issue of Pasquin) "an inferior work by a first rate man; a signboard by a Raphael. It has the 'made to order' stamp upon it, got up in a hurry, and not made to last long." Thackeray, on the contrary, was unfailingly treated with admiration. Algernon, another participant in the Noctes, complains that nowadays "one never sees Titmarsh in Fraser," and when he is asked about Vanity Fair, then also coming out in monthly parts, "You surely agree with all the world as to that work?" he retorts, "I'll listen to nothing against that. Scandalum magnatum is forbidden within these walls" (2 October 1847, p. 62).

Although Pasquin found most of its targets in London journalism and literature, the follies of the political and theatrical worlds were also within its range. The crudeness of the Chartist agitators, the antics of such laughable M.P.'s as the feuding Berkeley brothers, and the desperate competition between the great London theaters for singers and audiences-these were among the constant objects of Pasquin's satire. Most of its animosities, however, were parochial: 


\section{JAMES HANNAY}

one does not have the feeling in going through the few numbers of Pasquin that one is perusing a very special kind of gloss on history like that to be found, for example, in the early volumes of Punch. Needless to say, the two youngsters who were responsible for Pasquin lacked the experience, the tact, the genius of the men who sat around the Punch table; but for Hannay, at least, Pasquin proved an invaluable training ground for journalistic and critical ventures to come.

The eighth number of Pasquin, which appeared on 2 October 1847, contained a facetious paragraph "From our own Correspondent" in the style of the daily journalism of that period. Bearing the headline "EMEUTE IN THE CITY" and dated "Cornhill, September 25th.," it read:

I regret to inform you, that a disturbance which threatened to be attended with dangerous consequences, broke out here the other day. Some emissaries of the Man in the Moon went through the streets singing inflammatory songs, and telling everybody that Pasquin had been discontinued. The dreadful intelligence spread like wildfire. A mob assembled, and hurrying off to our publisher's, raised great shouts of Pasquin! Pasquin! Our Editor, who happened to be present, (reading our last letters from Lord John Russell,) addressed the meeting, in contradiction of the rumour, and distributed a large number of copies. The mob dispersed (2 October 1847, p. 64).

But this was in fact the last issue of Pasquin. Vizetelly speculated that the "clever and exceedingly pungent satirical journal ... had either frightened by its brute boldness, or tired out with its weekly losses, the timid capitalist who financed the speculation."' One of Hannay's friends, Joseph Crowe, a half century later vividly recalled the demise of the magazine: "One day, as we were taking the copy up to the printer's setting-room, what was our dismay to find the handpress descending the house steps in the grasp of a bailiff, and so an ending made to our pleasant venture of 'Pasquin!' "6

There is, alas, no record of mobs assembling to express their consternation at its death.

Within six months Hannay and Edwards had another opportunity to prove their prowess in the field of comic journalism. In March 1848, impressed by their spirited conduct of Pasquin, the brothers Vizetelly, who were at that time established in a printing business 
off Fleet Street, hired the two young men to found a new comic magazine, the Puppet-Show. ${ }^{7}$ Its objectives were set forth with surprising accuracy and completeness in an apparently facetious prospectus: "PUPPET SHOW: a pungent penny pictorial periodical, polishes popular politicians politely, punishes peevish prattling persons preaching pattern progress principles, pooh-poohs pompous presuming purse proud parvenus, puts-down paltry prolix publications, patronises playhouses pulling pointless performances to pieces, and publishes piquant pictures, playful puns, priceless poems, pleasing prose, popular parodies and political pasquinades. Princes, peers, and policemen, poets, players, and paupers, patriots, philanthropists, and puffed-up pretenders purchase the Puppet Show."s

As this masterpiece of intelligible alliteration suggests, the aims of the new satirical weekly were far more ambitious than those of Pasquin had been. The Puppet-Show commented on the public affairs of the day with a much stronger, more assured voice than its luckless predecessor had done. Also, whereas Pasquin had been almost entirely written by Hannay and Edwards themselves, ${ }^{9}$ their new publishers used the services of a number of other talented contributors in putting out the Puppet-Show. The work of such young writers as Shirley Brooks, Charles Mackay, Robert Brough, Edward Blanchard, Henry Vizetelly himself, and two old Pasquin butts, Angus Reach and a wild-eyed Bohemian scribbler named William North, appeared in the magazine at various times. ${ }^{10}$ And, unlike the pages of Pasquin, which had been bare of illustrations, the letterpress of the Puppet-Show was liberally interspersed with comic drawings by the Frenchman Gavarni and other masters of pictorial satire.

It may have been for any or all these reasons that the PuppetShow was an immediate success. Even if one regards the PuppetShow's frequent boasts about its own popularity with some skepticism, it is a fact that it survived for nearly a year and a half, in those days no mean achievement for a magazine of its class. Vizetelly later referred to the "temporary success" of the Puppet-Show and attributed it, in part at least, to the fact that the first number appeared just after the French revolution of February 1848: its writers, therefore, were able to capitalize on the English interest in the exciting events across the Channel. ${ }^{11}$ The early issues are full of scornful references to the flight of Louis-Philippe from his capital and his country, and 


\section{JAMES HANNAY}

the deposed king had the honor of being the first of the PuppetShow's many victims. But if the Puppet-Show was rather hard on the exiled monarch, it was not much more impressed with his successor as chief of state. Volume II of the magazine opens with an ironic dedication to Louis Napoleon, which is really an attack on the new president's incompetence. This same "plague-o'-both-your houses" attitude manifested itself in the Puppet-Show's approach to other public questions. Almost every issue, for instance, made cruel fun of the alleged ignorance, boorishness, and shiftlessness of the Chartists. According to the Puppet-Show, they were grimy buffoons who used devious means to further the noble ends in which they professed to believe. Nevertheless, the fact that Chartism was a reprehensible movement did not justify the measures which the Whigs took to suppress it or the severity with which the imprisoned Chartist leaders were treated. The Government, after all, was in the hands of men who sixteen years earlier had themselves "promoted the Reform Bill -which was a change in the Constitution-by violent language, tumultous meetings, and coarse threats" (29 April 1848, p. 51).

The Puppet-Show's distaste for the Whigs in general and Lord John Russell in particular, "the most dishonest and incompetent minister that ever pocketed a salary or made a stupid speech" (2 September 1848, p. 194), frequently sank to the level of scurrility, as in this dialogue between "The Showman and Friend":

SHowman. Now comes the hour when nature goes to rest,

Pigs to the sty and goslings to the nest,

To the dark heather flies the painted grouse,

Donkeys to sheds, but Russell to the House!

Why should this being such exception keep-

Go there to humbug when beasts go to sleep?

Why give us, when the peasant seeks his straw,

A booby's speeches and a tyrant's law?-

FRIEND. Night is the proper time for what is foul,

Night is the empire of the sombre owl,

At night, though lions sleep, still jackals howl!

At night, you find all cabbages exposed,

But the fair buds of fairest flowers are closed.

When darkness comes; its dreariness they shun,

And only ope to greet the rising sun. 
And shall not, then, Lord John his course pursue;

Quite undisturbed by justice or by you?

From useless virtue, friend, your mind exempt,

And, for your hatred, substitute contempt.

SHowman. When Bills and corn-crops both together fail,

When paupers seek for shelter in a jail,

When the Reform that Englishmen hold dear

Meets as opponents but a lie or sneer;

Cold as a corpse were he who did not hate

The worms that foul at once and hurt the state-

As insects on the trees in Eastern clime

Hurt by their bite, and dirty with their slime.

\section{List to their bray-}

Friend. But, friend, beware their hoof!

Statesmen who owe to threatening mobs position,

Are very strict indeed about sedition! (5 August 1948, p. 167)

Although such invective was the exception rather than the rule, any luckless miscreant who gave offense to the Puppet-Show took his public and private life in his hands. In June 1848, for instance, a French theatrical troupe, the Théâtre Historique, was prevented from putting on The Count of Monte Cristo at Drury Lane by a group of agitators who professed to believe that allowing foreigners to perform in London would deprive English actors of employment. A leader in this movement, which the Puppet-Show regarded as foolish and dangerous, was an actor named Cowell, who laid himself open to abuse of a particularly merciless sort. His personal qualities were attacked:

THE man Cowell makes a great fuss about his having supported the British drama, by driving away the French actors from Drury Lane. How unfortunate that the British drama cannot support Mr. Cowell, in which case he could be ridiculous on the stage without being obscene at the Cider Cellars.

The man Cowell is so perfectly intolerable, that even if the British drama could support him, it is more than the audience could!

While on the subject of Cowell, and his supporters, it may be asked who are his present supporters? We believe they consist entirely of some friends who support Cowell home when intoxicated (8 July 1848, p. 129).

And, in the same number of the Puppet-Show, a review of The 


\section{JAMES HANNAY}

Daughter of the Regiment was little more than a pretext for exposing his professional incompetence:

The man Cowell played the fool and the Steward in the performance. His conception of the comic appeared to be to kick up his legs behind every now and then, like an angry donkey, and to scream out his part like an ill-taught parrot, or a bull-frog with a cold. The person of an actor is a fair subject of criticism (vide the Rosciad and Hazlitt, passim), so we may state at once, that the person of Cowell is quite on a level (a very low one, by the way) with his mind. His face is mean and vulgar, and his figure awkward and ungainly; his features without expression, and his movements without grace; so that those who see him in the dock next sessions (previous to his going to "star" it at Brixton) will be little gratified by the view. This is severe treatment, we admit; but Cowell has brought it on himself. He who has tried to ruin others (men his superiors too) can expect no favour himself. The gentlemen of England must be expected to be indignant at having been deprived of an intellectual enjoyment by the violence of an obscene buffoon (8 July 1848, p. 131).

As Pasquin had done, the Puppet-Show repeatedly attacked such rival magazines as Punch and The Man in the Moon for dullness and plagiarism. ${ }^{12}$ Also in the manner of Pasquin, the Puppet-Show assailed some of the leading contributors to these magazines, especially Albert Smith (who had, however, severed his connection with The Man in the Moon about the time the Puppet-Show first appeared), Mark Lemon (the editor of Punch), and Douglas Jerrold. Lemon's pretensions to authorship were regularly ridiculed. " 'Is Mark Lemon,' writes a correspondent, 'one of "the most eminent writers of the day;" and if so, what does he write?' Yes, he is one 'of the most,' \&c., and he writes the Index to Punch" (25 March 1848, p. 11). And Jerrold was still King of the Cockneys.

The Petition of the Showman and His Contributors to Mr. Douglas Sheweth, JERROLD.

That Your Petrtioners have interests totally in opposition to those of Punch.

That the stupidity of Punch is the PUPPET-SHow's good fortune; and that anything which may contribute to the increase of the said stupidity of Punch, will be hailed with joy by Your Petitioners, and its authors duly honoured.

That Your Cockney Majesty has it in his power to contribute, and 
does in the most obliging manner contribute, to the said stupidity of Punch, though not to the extent which Your Petitioners would desire.

Your Petitioners, therefore, pray, That Your Cockney Majesty will, in his gracious kindness, write, and cause to be printed in the columns of Punch, as large an amount of Your Cockney Majesty's original articles as Your Cockney Majesty may in his merciful goodness think fit.

And Your Petitioners will ever pray, \&c. (4 November 1848, p. 85).

A number of the Puppet-Show's other constant targets-William Howitt, the Whittington Club, the Berkeley brothers-had also been objects of Pasquin's satire, but occasionally the Puppet-Show went after bigger game, the royal family itself. There were, for instance, some snide references in the spring and summer of 1848 to the fact that Prince Albert had rather ignominiously slipped off to the Isle of Wight when a Chartist uprising in London was feared, in spite of his position as Colonel of the Scotch Fusileers. ${ }^{13}$ Other mild gibes at Victoria and Albert are fairly represented by the following:

Nothing New.-The papers mention, as something worthy of note, that when Her Majesty and Prince Albert were in Scotland they visited the distillery of Messrs. Begg and Co. As for ourselves, bearing in mind the frequent occasions on which Her Majesty and Consort have recourse to her faithful Commons for grants for new palaces, dog-kennels, \&cc., it does not at all surprise us that these Royal personages should have gone to Begg (25 November 1848, p. 115).

In discussing the two most considerable novelists of the day, the Puppet-Show, like Pasquin before it, consistently praised Thackeray and condemned Dickens' work on those relatively few occasions when it was mentioned. For example, in its review of Dickens' 1848 Christmas book, The Haunted Man, the Puppet-Show pointed out that "his later Christmas works have been complete failures, and this last, which aims at being very supernatural, is chiefly so in this respect, that it is supernaturally dull" (30 December 1848, p. 155). But when David Copperfield began appearing the next year, the Puppet-Show claimed to see signs of improvement in Dickens. A letter from a supposed Cockney admirer "To Charles Dickens, Esquire" is significant because it indicates that in the opinion of the Puppet-Show Dickens' work was losing some of its appeal to his erstwhile lowbrow readers and becoming more like that of Thackeray. The author of the letter remarks that "I always like your 
style better than them quiet, puny writers, Cervantes, Goldsmith, Fielding, LeSage, and the like," but this is, alas, changing.

You're a falling into the werry same herrors I've just said you was exempt from! In yer Copperfield you've been imitating the wile himpostor. Thackeray that everybody cries up so; you've been following his simplicity as close as you can. My dear, sir, simplicity don't suit all minds. ... Mr. Thackeray is a scholar, I hear-you despise scholars, you know, Mr. D. (with good reason, no doubt,)-don't imitate him. A mere quiet homely writer, telling his story nat'rally, whose characters drop quiet tears, and not the dashing, spluttering, hot Geyser-spring ones of your characters, ought'nt to be imitated by the likes o' you. You're above him; keep so. I don't know what this "simplicity" will come to in literature. Here's Bulwer at it in the Caxtons; all you writers seem trying the quiet respectable dodge, and a selling your wares in a careful threadbare black coat, like some of the willainous beggars in the Strand.

Yours, (if you drop Thackeray,)

John Cute Bumprin (III, 216).

As this letter suggests, the Puppet-Show's attitude toward Thackeray was consistently friendly and admiring. In the listing of the starters in the "Literary Derby" of English comic writers, for instance, Thackeray's entry is the only one which reflects a favorable opinion of the author's merit: "Mr. Thackeray's Humour, by Observation, out of Society." Some of the other "horses," by contrast, are "Mr. Jerrold's Bitterness, by Bad Temper, out of respectability," "Mr. Mark Lemon's Dulness, by Himself, out of His own head," and "Mr. A. B. Reach's Imitation, by Man in the Moon, out of Punch" (27 May 1848, p. 81). From time to time, isolated paragraphs were devoted to praise of Thackeray. For example:

RESPICE Finem.-A friend of ours says, that he likes each succeeding number of Pendennis less than the one which preceded it-because it brings him nearer to the end (III, 3).

The author of Vanity Fair was recently introduced as a character in a serial of Charles Lever's. How remarkable that he should be in anybody's bad books! (III, 51).

\section{EPIGRAM ON "VANITY FaIR"}

Yes, 'tis a fact proved by the past,

That worms get at most books at last,

But be consoled-in that far age

They'll turn to glow-worms on thy page (III, 223). 
It is, of course, impossible to determine the authorship of the pieces in the Puppet-Show, all of which were published anonymously. Nevertheless, it seems clear that Hannay had a powerful hand in running the affairs of the magazine. Not only do its contents faithfully reflect his social, political, and literary tastes and prejudices, and such lifelong interests of his as heraldry ${ }^{14}$ and classical scholarship; ${ }^{15}$ but on a number of occasions he, alone of all the contributors except Edwards, was able to "puff" himself and his works in its columns. For example, two of Hannay's books, newly published, were mentioned favorably in an article on "Tempting Titles."

Some of our authors are very fond of appealing to the brutal appetites of the mob ... and on this principle call their productions "A Glass of Ale and a Sandwich," "A Pot of Porter and a Screw of Tobacco." Among these we must rank "Biscuits and Grog," which we confess contains far more intellectual nourishment than the majority of the works which are held out as something to be devoured by the multitude. A book is being now advertised under the very drinkable title of "A Claret Cup;" and we have no doubt that it will be shortly followed by "A Glass of Port Negus" (2 September 1848, p. 201).

Another discussion of literary nomenclature later in the year brought in, rather gratuitously, another new book by Hannay: "WE perceive that the publisher of the forthcoming work entitled King Dobbs, after entreating the public attention to the author in several sentences of great power and beauty, ends by calling him the 'Charles Dickens of the Ocean' " (23 December 1848, p. 148).16

Both Hannay and Edwards figured in a rather elaborate joke in the Puppet-Show of 2 September 1848. On 29 July there had appeared in the Lancet a letter, signed "Philologist," questioning the meaning of an ambiguous sentence in a medical treatise written in Latin. A fortnight later, the Lancet printed a letter from Hannay in which he gave his reading of the sentence and acknowledged "the kind and valuable assistance of Mr. Sutherland Edwards, whose acquirements in this branch of learning have long contributed to the instruction of his friends." 17 The Puppet Show's paragraph commenting on this second letter was headed, with more irony than most of its readers probably suspected, "Audacious Puff":

IN the Lancet, of two numbers ago, we perceived a letter containing what the writer intends for Latin criticism, signed by some person calling 
himself James Hannay, and introducing another equally obscure man, one Sutherland Edwards, as having assisted him in this absurd performance. We are not aware whether Hannay belongs to the firm of Hannay, Dietrichsen, and Co.; but we are afraid those respectable persons would disclaim the connexion with considerable alacrity. As for Edwards, we have no doubt that he is the well-known Henry Edwards of "egg-powder notoriety"-the "Sutherland" being merely introduced by way of blind. We trust that such a sensible man as the editor of the Lancet will not allow his paper to be made the vehicle of puffing two illiterate tradesmen, whose knowledge of Latinity is doubtless altogether due to the prescriptions perused by the first-named of these insignificant personages. Edwards, we suppose, had been "egged-on," as he would say, by some of those friends to whose amusement he is alleged to have contributed. . . Having performed our duty to society, by knocking these two fellows' heads together, we conclude by expressing a hope that some of their friends will muzzle them, to prevent similar extravagances (2 September 1848, p. 201).

It is probably not without significance that this paragraph follows immediately the "puff" of Biscuits and Grog and A Claret Cup referred to above.

Although little is known of the details of Hannay's private life in London during these early years, much can be inferred from scattered observations in his own writings and evidence in the memoirs of a number of his friends. First of all, he moved about a great deal. The retrospective notes in his diary record a dozen changes of residence between 1845 and 1850; almost always, however, he lived near the Bohemian haunts of Covent Garden, Fleet Street, and the Strand and within easy walking distance of the British Museum, whose Reading Room he began to frequent regularly in 1846. Some of these moves, at least, seem to have been involuntary: according to William Rossetti (not always a reliable witness), Hannay was perpetually in debt to his landlords. Dante Rossetti had told Ford Madox Brown that Hannay "used to be so hard up that he used never to be at home in the daytime because of his 'rent.' He used to go out before the people were up, and go home when they were in bed. This was constant with him, and he never apparently ate at all."18 It is probably significant that Hannay periodically returned to live with his father, first in the Mornington Road and later in Hertfordshire, after the elder Hannays had settled near Barnet. 
Convivial amusements formed a large part of his life. Francis Espinasse's sketch of Hannay referred to the "joyous though generally impecunious companions of his early days of authorship, their jovial tavern-life, with its flashes of merriment, their feasting alternating with fasting, their shifts for raising the wind, their occasional capture of a capitalist to be lured into floating a new journal when an old one had died of inanition." 19 Looking back a half-century in 1895, Joseph Crowe remembered Hannay as a youth "fresh from Malta"; "in the evening he would sally forth with as many congenial spirits as he could muster, drink drinks at the bars of public houses, make speeches at debating clubs, and end up at midnight by knocking at the doors of a railway station and ordering a special train to take him to Dover; or he would get his friends together and tail on at the pit entrance of Drury Lane, and pelt the foremost rows of people from behind with oranges; then, after witnessing half the performance, rise in the pit and describe the piece as rubbish, and get turned out by a friendly policeman." But, it is important to note, even Crowe concedes that "no amount of dissipation prevented him from work." ${ }^{20}$ For London's Bohemia at mid-century was not a Skid Row for aesthetes. Frederick Greenwood, who later gained distinction as editor of the Pall Mall Gazette, insisted on this as he recalled the "tavern life" of his and Hannay's youth. This Bohemia "was not a land of sojourn.... They who were drawn thither made the tour, came forth, threw off the loose cap of travel, donned the smooth and shining tile of civilisation, and thenceforth roamed no more. Young men who thenceforth became palaced artists, or high scribes and scholars, or grave judges and counsellors of the Queen, resorted there awhile for nothing more than a jovial clamour of wit and clash of word-a laughing jail-delivery of thoughts and sentiments which otherwise might never have got release." 21

There was, then, no irreconcilable conflict between Hannay's work and his really quite harmless carousing. Much of his energy as a writer was expended on the comic magazines to which he contributed, and, as Hannay pointed out in the slightly fictionalized account of his early career which appeared in the unfinished novel Bagot's Youth, "AMONG the ancients, the god of wine was also the god of the comic writer. This is a significant fact. Bagot was never so convivial and desultory in his habits as during these comic days." 


\section{JAMES Hannay}

The same passage also explains, in some measure, why young Hannay's political views were as difficult to classify as they were forthrightly expressed. "His set tilted at all comers. They had no particular politics,-or, rather, what they called their politics were determined by accident.... This is an age of hybrids; and if you weigh strictly what any man says or writes before five-and-twenty, you will find that in trying to prove other people scoundrels you have proved yourself an ass. Consistency is not always a virtue; and who respects MacFlunkey for having been a blockhead from the cradle, without swerving once?"22

His delight in public speaking, which had already manifested itself during the court martial, led him to vigorous participation in debating societies. The critic and journalist William Moy Thomas met him for the first time in 1846 when Hannay was "a handsome bright eyed lad...making a speech of a somewhat pugnacious character at a debating club and amidst loud cries of 'Oh! Oh!' was recommending his opponents not only to reconsider their politics but to 'pay decent regard to the rules of Lindley Murray.' "23 $\mathrm{He}$ was bold enough at the age of twenty to attempt the lecture platform: "I advertised a Lecture on the French Revolution and got Two hearers-who were personal friends, and with whom I afterwards spent the evening." 24

The gift of friendship with which Hannay seems to have been richly endowed attracted to him not only the boon companions of convivial club life and comic journalism, but also a very different "set"-the earnest young men who formed the Pre-Raphaelite Brotherhood, particularly D. G. Rossetti and his brother William. Just how Hannay and the P. R. B.'s happened to be drawn together remains something of a teasing minor mystery, though the Scottish sculptor Alexander Munro seems to have been involved, but by 1849, William Rossetti wrote in his Reminiscences, "and for some years afterward, we two were exceedingly intimate with Hannay." Rossetti draws a vivid contrast between the Brotherhood and Hannay's Bohemian cronies:

The P.R.B.'s were all high-thinking young men, assuredly not exempt from several of the infirmities of human nature, but bent upon working up to a true ideal in art, and marked by habits generally abstemious rather than otherwise. To deny themselves the good things of this life 
when forthcoming was not their notion, but, having next to no money to spend, they stuck to necessities and eschewed superfluities. Dante Gabriel, it is to be acknowledged, was by nature of an unthrifty turn; but, hard compulsion being now upon him, he only trifled with shillings when he would have dearly liked to disperse bank-notes. The Hannay set were equally impecunious, but not equally abstemious. They also may have laid out little money, having laid in still less; but they breathed the atmosphere of "devil-may-care," and were minded to jollify as best they could. ${ }^{25}$

Holman Hunt, the historian of the P. R. B., was impressed by the young Hannay: he "was not such a man as could be found every day, for he was of inexhaustible spirits and had a fund of recollections of ever living words from the lips of men who had gone otherwhere. The Queen Anne and Georgian writers he quoted with unceasing zest."'26

Perhaps the most important acquaintance Hannay made during these years of apprenticeship was that of Thackeray, whom he met in the spring of 1848. Again, we do not know what Thackeray, who was sixteen years Hannay's senior and the literary lion of London after the triumph of Vanity Fair, could have found in common with the obscure twenty-one year-old journalist, but the friendship that slowly ripened between them was to have a marked effect on Hannay's later successes, particularly in criticism.

If Hannay had confined himself to satirical and polemical journalism during these years, he almost surely would never have risen above the level of the scribblers who then formed the greater part of his circle of friends. But he continued his habit of serious, intensive private study, begun in the Navy and now encouraged by the proximity of the British Museum with its incomparable resources. He thus laid the foundation for the impressive body of solid, responsible criticism which he produced during the last twenty years of his life. Even in a lighter vein, he did not remain content with ephemeral jeux-d-esprit, but began working on an ever larger scale as a writer of naval stories, climaxing this phase of his career with his first (and in some ways greatest) popular success, Singleton Fontenoy, in 1850.

The earliest volumes in this series were two slim "Sketches of Mediterranean and Naval Life," published at a shilling apiece in 
1848, when Hannay was twenty-one: Biscuits and Grog and $A$ Claret-Cup. Neither of these little books pretended to be a fictional narrative in the ordinary nineteenth century sense. They were plotless: there is action, of course, but it is subordinated to description, character drawing, and, especially in A Claret-Cup, to polemics. Nor did Hannay attempt anything like structure. Such organization as the books possess is loosely chronological; when Hannay has finished what he has to say (or filled the agreed-on number of pages), he does not conclude: he stops. As to the people who crowd Biscuits and Grog and $A$ Claret-Cup, they are types rather than individualized human beings. Even Percival Plug, the protagonist of both sketches, is hardly explored with any more penetration than the other officers we meet: he is simply a reporter and recorder without any significant subjective complications of his own. Finally, these slender volumes contain little really original material. A comparison of the two books -the characters, events, places, and ships of which they treat-with Hannay's service record and retrospective diary notes shows that almost everything in them was directly suggested by his Mediterranean experiences of 1840-1845.

Nevertheless, there is a great deal of lively and interesting writing in both Biscuits and Grog and A Claret-Cup, and they remain surprisingly readable.

From the beginning of his career, Hannay at his best showed himself to be the master of a lucid and vigorous style, which was especially effective in descriptive passages. His vivid accounts of diverse aspects of naval life suggest why Hannay was later to be compared with Captain Marryat: there are knowledgeable but never pedantic explanations of shipboard practices and traditions; analyses of various kinds of officers and men; above all, perhaps, obviously authentic reports of the jollifications of midshipmen.

On the table glittered two bottles of sherry; but these were more for ornament than anything else. The great attraction, and chief pride of the banquet, was the mess soup-tureen, filled to the brim with whiskey punch. It glowed like a hot spring in Iceland; and the slices of lemon floated in it like the islands in the Archipelago. All had been made right outside. The quarter-master was left to take care of the watch. The captain was on shore, enjoying what some people call "society"that is to say, the company of a respectable family, with a snuffy old 
father; a pious mother; two young ladies playing on a piano out of tune; and a small quantity of mulled elder wine....

Our conversation turned first, of course, on "the ship." ... We then went on to talk of our friends on various parts of the "station." ...

"You know Davies, don't you?" said Dulcet.

"Yes," replied Julian, "as Churchill says,

What of him?"

That Davies hath a very pretty wife.

"He has bolted from Malta, with one of the singers at the opera, and gone to Palermo!"

"By Jove, what a windfall for Malta! Something to talk about for a week. What's become of his wife?"

"Oh!" said Dulcet, "I have reasons for not pitying her, which it is unnecessary to specify; but I pity his creditors most." ...

"Well," said Julian, "let us cut the service for a time. You brought 'Tancred' from Malta with you, Plug: what do you think of it?"

"Why, the general opinion seems to be, that the first volume is the best; and the part about the east, inferior. I think quite otherwise. The first volume would naturally please many people best, because it gives them a glimpse of what they call 'high life;' and there is a prurient snobbish curiosity, which is gratified by that kind of revelation. But, I apprehend that the artistic power of the writer is more shown in the description of eastern life and eastern scenery. . . But one great drawback is, that one cannot divest oneself of the idea, that the author is only playing a part-that this eastern enthusiasm is only an affectation of Mr. D'Israeli's; and that he simply assumes it, as one would an oriental dress at a fancy ball, for the sake of making an effect...."

"Come," cried Dulcet, "for God's sake don't spout literary articles! Another tumbler, and we shall be having Julian haranguing on the immortality of the soul. I know the gradation perfectly: an impeachment of the Whigs-tumbler first: quotations from Cicero's second philippictumbler second: criticisms on D'Israeli, Savage Landor, and Thackeraytumbler third: wholesale sarcasm-tumbler fourth: and so on, to drunkenness, stuttering, singing, and Pomponatius $D e$ immortalitate animarum!"

This burst of Dulcet's made us all laugh; and the ladle began to sink and rise in the soup (or rather punch) tureen, with the regularity of a piston.

When men get too tipsy to talk they take to singing, and this was the case now. The Scotch assistant-surgeon began the Laird of Cockpen, which, combined with the Poachers from Dulcet, the Pope from the clerk, the Lesbia semper hic et inde of Prout's from Julian, and $A$ white sail 


\section{JAMES HANNAY}

and a flowing sheet from myself, made rather a curious effect. So, the surgeon, who was in the adjoining gun-room, reading the Lancet, seemed to think, for he sent in a boy to remonstrate, and was informed in reply, that he had better put his head in a bag: this he declined, but one thing he did do-he complained to the captain....

The end of the evening was, that some of the party rolled over their hammocks in a most ridiculous manner in attempting to get into them; the clerk walked, or rather staggered into his office, and made an insane attempt to walk up the mainmast, which came down through the corner of it. Julian and I swore eternal friendship under the main hatchway, much to the annoyance of the boatswain, whose cabin was in the neighbourhood.

Next morning came, and the whole mess were brought up before Captain Troubadour, on the complaint of the doctor (CC, pp. 58-66).

Hannay's descriptive powers were frequently expended on Baedeker-like accounts of various places on the "station" visited by Plug and his friends. At their best, these are excellent; occasionally, however, they are marred by a certain self-conscious mawkishness, as in this passage describing the countryside near Smyrna. "[Let the traveler] pause on the camel's bridge, which the caravans cross in leaving the town; and turning to the right and left, contemplate on one side the magnificent cypress forest which forms the Turkish cemetery; and on the other, the bright expanse of the country. The first is the perfection of shade; the last of light; and if the one has a greater interest, as the last resting-place of the departed, the other, by its bright beauty, is calculated to dissipate the gloomy impression which the sight of a thousand tombs makes on the thoughtful mind." It is only fair to add that Hannay does not let this series of reflections run on unchecked; the "gloomy impression" is eradicated almost immediately by the appearance of a "merry party of midshipmen" who care nothing about such philosophical meditations, "each mounted on an extraordinary quadruped, which no man could ride in London without being mobbed immediately" ( $B G$, p. 66). And within two pages there follows a mock-reverent description of the plains of Troy which reminds the reader of Innocents Abroad. "Who can look unmoved, I ask, on those fields where the Hector and Achilles of his boyish days were wont to contend? Have we then been birched in vain? Did we then remain ignorant of science, and French, of modern history and modern discovery, of the mysteries of 
statistics, and the value of commerce, for the sake of knowing Priam better than George III; Hecuba better than Queen Anne; Achilles than Marlborough; the Scamander than the Thames; Mythology than Christianity; and shall we not be able to muster a decent show of classical enthusiasm on the very plains of Troy?" (BG, pp. 68-69) A strong vein of comic realism crops out in other descriptive passages, such as the following account of a typical performance at the shabby opera house at Valletta. After much unruliness in the theater,

the curtain rises, and discloses a shaky castle, trees with mysterious lights gleaming through the trunks, and a moon terribly in want of snuffing.

Perhaps we have Lucia, with the retainers intended for Lowland Scotch, of the era of Queen Anne, dressed in kilts, all of different patterns, and none of any recognized tartan; or an operatic version of Romeo and Juliet, in the concluding scene of which the two lovers are seen singing in a duet together, in the agonies of death, in the tomb; or, an opera founded on the tale of Sappho, in which that poetical heroine is represented by a stout, middle-aged woman, and her leap from "Lencadia's [sic] Rock," by a dirty-clothes-bag pitched from a pasteboard promontory -on which the curtain falls, amidst great applause, and "Rule Britannia" is played by the orchestra ( $B G$, p. 128).

This unevenness of style and treatment is one of the most disquieting aspects of these two early books. Hannay moves too easily from straightforward narration and description to evocative passages which tend to be maudlin to unashamed satire and farce. The reader winces at the appearance of such outrageously improbable names as Sir Beelzebub Windbag, Lord Caskobeer, Lady Ostrich, and Sir Gabble Cocktail in a volume of supposedly realistic sketches, but these and other lapses may be explained, if not forgiven, as vestiges of Hannay's career in satiric journalism.

Hannay's fondness for polemics further disrupts such consistency as the books display. He was only too ready to drop whatever he was doing in order to engage in pungent crusading against what he considered to be flagrant abuses: for example, the nepotism and political patronage involved in granting appointments and promotions to naval officers, the incompetence and brutality of many of those officers, the expensive futility of English attempts to suppress the slave trade, the injustice of naval courts-martial, and the savagery of flogging. 
One other significant aspect of Hannay's first two books remains to be noted: they contain abundant evidence that the two literary allegiances which were to have a marked effect on Hannay's career as a writer were already well formed at its outset. In the preface to Biscuits and Grog he pays tribute to Carlyle and Thackeray as the most serious and estimable writers of the day by expressing the hope that his modest book "may occupy a few moments of the time of the reading public, when the day's study of grave and high instructors is over-when Carlyle has been laid aside; and no fragment of Thackeray not already devoured, can be obtained..." (p. iv); this is only the first of several admiring references to the two authors in both Biscuits and Grog and A Claret-Cup.

Hearts Are Trumps (also 1848), Hannay's next book, is another brief narrative; but it represents an advance over its two predecessors in that this time he tried to graft a plot on to his semi-autobiographical account of naval life.

The hero is one Harley Sidmouth, the son of a successful merchant and descendant of an honorable old family. Harley runs away to sea because his father intends him for a commercial career. In Harley's absence, his wicked brother William intrigues against him; with the aid of the servant Gibbs, he tries to supplant Harley in the affections of his father and his sweetheart, Helen. William's plot to disgrace Harley by having him convicted of the theft of a diamond ring from Mr. Sidmouth fails because of Gibbs's unfortunate propensity to strong drink; Mr. Sidmouth's character, as well as his attitude toward Harley, softens; Harley is reconciled with his father and marries Helen. The subplot concerns a similar softening in the stern Captain Fairfax after he is indirectly involved in the death of his natural son, who is serving as a seaman under him on the Mammoth. As a result, Fairfax now consents to a match between his daughter and a young officer on his ship.

As may be seen from this summary, Hannay's first attempt at plotting makes rather painful reading. The structure of the little novel is shaky indeed; the book is full of stock situations and stereotyped characters. Hearts Are Trumps is at its best when Hannay, on familiar ground, recounts the banter of young naval officers, but it does not contain anything in this line which is not at least equally well done in Biscuits and Grog and A Claret-Cup. Nevertheless, he 
was groping his way toward something which more nearly resembled the usual novel of his day than his first two books had done, and his efforts soon met with a surprising degree of success, in King Dobbs (1849) and Singleton Fontenoy (1850).

In a sense, King Dobbs is no better unified than Hearts Are Trumps. It is really three novels in one: another series of sketches of naval life in the Mediterranean; a fairly complicated but conventional romantic story, with Gothic nuances in the characters of the consumptive young villain Limsdale and his mad uncle, the father of the heroine-in-distress, Flora Limsdale; and a Carlylean analysis of the condition of England. Nevertheless, though the seams show only too clearly, the book as a whole is far from a failure.

The naval sections of King Dobbs go over much the same ground as the earlier books, with no perceptible loss of vigor. A good deal of the material in these sections will strike the reader of Biscuits and Grog, A Claret-Cup, and Hearts Are Trumps as déjà vu: the reappearance, in minor roles, of characters like Percival Plug, Sir Booby Booing, and Captain Gunne of the Orson; the renewal of polemics on such subjects as the African slave trade; the Mediterranean and Near Eastern travel sketches. Also, Hannay appears to take delight in working in naval anecdotes which he has been unable to use elsewhere. We hear, for example, the story of Lieutenant Bulbous of the Tulip, who is discovered asleep on the watch by his captain. In reply to his reprimand, Bulbous laments, "Why, sir, I came on deckfound it blowing-raining -I can't do it for the money!" (p. 47) Or there are the adventures of one Hickory in the West Indies: "his going for a ride inland somewhere, in his clerk's uniform, passing himself off for a general officer, reviewing the Spanish troops, and expressing himself highly satisfied with their appearance and efficiency" and his trip "on shore without leave, but with a couple of bottles of brandy, from the Spigot schooner" which culminated in his being "found, two days afterwards, in a state of delirium tremens, in a family vault" (p. 162).

However, these aspects take up a much smaller proportion of the book than they had done in Biscuits and Grog, A Claret-Cup, or Hearts Are Trumps, and the autobiographical element, though undeniably present, is almost completely concealed. The Mediterranean episodes occur in settings which Hannay had visited and knew well, 


\section{JAMES HANNAY}

but there is no Plug-like alter ego among the major characters. Despite the title and an opening chapter devoted to an account of his parentage, Dobbs is not the protagonist of the novel: he is a fat, amiable, mildly comic nonentity whose main function is to inherit the money which three self-consciously world-weary young officers with whom he strikes up an acquaintance in Portsmouth use to purchase the yacht Baboon. This vessel carries them on a three years' cruise to the Mediterranean, the Pacific, and back to England during which they experience the adventures which make up most of the novel. Two of the three officers embody traits which remind one of the young Hannay: Chilton is full of rather windy and inconclusive theories about the nature of things, and Carisford is somewhat given to high-spirited pranks. But neither of them, and certainly not the nebulous Pereira, the third member of the trio, can justly be identified with Hannay.

The romantic plot deals primarily with Carisford's wooing of the unfortunate Flora Limsdale, whom of course he eventually wins, despite the machinations of her demented cousin, conveniently removed from the scene by his consumption just in time for a happy ending; there is also a rather ordinary love affair between Chilton and Dobbs's sister; and poor Dobbs himself is nearly trapped into a match with the plain daughter of a socially ambitious middle class English tourist couple. There is nothing new or unconventional here, but some of the characters and events on the fringes of the plot are worthy of mention.

Two of the leading figures in King Dobbs are endowed with remarkably eccentric fathers. Chilton's gregarious parent has earned the nickname "Toe" by his unique method of making friends: he begins conversations with attractive-looking strangers by stepping on their toes and begging their pardon, and in the course of the ensuing pleasantries invites them to dinner. Old Mr. Carisford carries his devotion to the letter of the law to ludicrous extremes. He insists on seeing strict justice done by having his son court-martialed for desertion, though everyone in the Navy is happy to be rid of him and say no more about it. His conversation with Captain Balder Dash, Carisford's commanding officer, deserves at least partial quotation:

"I am to understand that my son is a deserter, sir?" 
"Why, sir," replied the captain, with a quiet air, "strictly, perhaps, he may be so described; but in these times-"

"These times, sir! I apprehend that Her Majesty's navy is still under the articles of war, as confirmed, I believe, by an act, passed in the reign of George the Third?"

"Oh, most certainly, sir!" said Dash, with great promptness. He was a rigid disciplinarian ... and pricked up his ears at the words "articles of war," like a war-horse at the sound of the trumpet.

"Very good-very good," said Mr. Carisford, with the air of a man, who feels that he has a painful duty to perform, but has made up his mind to it. "May I ask what steps you have taken in the matter?"

"I wrote to the Admiralty, informing them of the circumstance; but have received nothing further in reply, than an acknowledgement of the receipt of the information."

"Just like the Whigs-just like that miserable faction," said the old gentleman, while the captain's face assumed an appearance of terror, and he looked round, to see if the blasphemy had reached the ears of anybody; for he was always a Whig-when the Whigs were in-was the highprincipled Captain Balder Dash.

"The punishment for desertion is hanging, I believe?" inquired the bereaved parent, with a business-like air.

"Yes, sir," answered Dash, opening his eyes.

"Just so-just so! Do they hang offenders at the starboard, or the larboard yard-arm?"

Dash opened his eyes still wider at this question; but Mr. Carisford looked perfectly serious; and as Dash's perception of the ludicrous-like that of all pompous men-was by no means keen, he did not consider the inquiry very ridiculous. $\mathrm{He}$, in fact, began to esteem Mr. Carisford more highly, as a man who had the most correct notions of discipline, and answered him-"The larboard generally, sir," with considerable respect.

"Thank you-very good!" said his companion; and he proceeded to pull out a pocket-book, in which he entered the words "hanging-larboard yard-arm-desertion-eight in the morning," with great minuteness, crossing the t's very formally, and ornamenting the page with a small Hourish at the bottom (pp. 153-54).

Such characters as the unprincipled attorney Limp and Tartan, a scheming divine, are further indications of the manner in which Hannay is extending his range in this novel.

$\mathrm{He}$ is also becoming more adept in his handling of scenes which have nothing nautical about them. Late in King Dobbs there is a 


\section{James HanNaY}

solemn discussion among a group of superstitious rustics in the taproom of a west country inn which reads almost like a passage out of Hardy (pp. 245-46), and Hannay's description of the splendid drawing room of a splendid house in Tavistock Square is reminiscent of the satiric thrusts against vulgar middle-class ostentation in Thackeray or Dickens:

Everything in the room was of the rich heavy description. The chandelier was so extensive, and such numbers of crystal drops sparkled in it, that the astonished gazer would readily admit the truth of what the lady was in the habit of telling all her friends with regard to it, viz:-that the united exertions of a man and a boy, for an entire day, were required to clean and put it in order. At one side of the room, on a table, stood a glass-case of stuffed humming-birds, all green, crimson, and gold, with nests as small as a girl's mouth; on the other, was a glass case covering two graceful figures, whom Mrs. Forrester knew (for the shopman had told her husband, when he paid for them) to be "Bacchus and Ariadne." The damask sofas were not degraded by covers, for the lady saw no use in taking particular care of them-"Had not Mr. Forrester got plenty of money?" (p. 4).

The social satire is centered in Chapters XII through XIV of the novel. These are devoted to an account of life on Somniata, a Pacific island which "King" Dobbs and his cronies come to rule as the result of a highly improbable series of events. Once the reader has adjusted to the violent contrast between the mood of the earlier chapters and the fantasy of this section (he is asked to make the leap, which involves changing the scene of the action from the west coast of Africa to the Pacific Ocean, in a few paragraphs of Chapter XII), he can settle down to a surprisingly effective and entertaining satiric view of English traits and institutions.

In several respects, Somniata anticipates another nineteenth century utopia, Butler's Erewhon. For example, the Somniatans' religion, like that of the Erewhonians, is full of paradoxes. They worship an idol called Foggum. "It was a noble image of wood, somewhat, however, decayed, for though the revenues of the Somniatan religious institutions are large, the priests are numerous and well paid, so that the Gods are somewhat neglected on their account. The Somniatans could never clearly explain to strangers, how this was; how, when religion was at a low ebb, the priests were so very well off, seeing, 
that one would think, the first object of the Foggum establishment, would be to provide for Foggum himself. It certainly appears an anomaly" (p. 216). Somniatan public school education, like that of Erewhon, is based on a "hypothetical language." "... the higher orders among the Somniatans were chiefly educated not in their own language, but in the language spoken by the Cockobees of the neighbouring island of Swango, two thousand years before. They were flogged at the shrines of the Cockobees in their infancy-they laboured at the books of the Cockobees in their youth, they neglected them in their manhood-and forgot them in their old age.... But woe to anybody who meddled with the system!" (p. 216)

The Somniatans have a "philosophical novelist" who is strongly reminiscent of Thackeray and a prophet named Tomasso, habitually garbed in a pall, who of course represents Carlyle. When Dobbs attempts to reform the natives in the spirit of Tomasso's teaching "that a radical change must begin in the inmost hearts" of men, he meets with resounding failure: the islanders revolt, and Dobbs and his friends are forced to flee.

He had thought to influence them through their religion; but what could be done by religion, where there was no faith? They were willing to pay for their religion, with a certain grumbling demur, without being influenced by it; just as the poorer among them paid taxes for windows, through which (owing to their impurity) they could get no light. The cases were precisely similar. What was the use of hero-worship, where there were no heroes? and where, too, there was such a total want of the insight necessary to spy out a hero through external environments, that, as Chilton remarked, had St. Paul come among them, he would have been excluded from "polite society;" had Peter the Hermit come, he would have been sent to Bedlam; while St. John (fresh from Patmos itself) would have been laughed at as a fanatic; and Moses (arrived from the Wilderness) would have been black-balled at their Travellers' Club (p. 223).

Just as the subject matter of King Dobbs is rather loosely joined, so the manner in which it is handled tends to be uneven. Hannay's prose, particularly in the naval episodes, is generally clear and vigorous, but it occasionally descends to bathos, notably in those sections of the romantic plot in which he takes himself too seriously. However, there is also an epigrammatic sharpness to the style which had not been so much in evidence in the earlier fiction. Some samples 


\section{JAMES HANNAY}

will indicate its quality. On a vapid young dandy: "He had an elegant way of saying smart drawing-room things; and when he spoke of high life, you would have fancied you were listening to a parrot, whose cage had hung for years in the boudoir of a countess" (p. 201). On Westminster Bridge: it "has become a ruin without becoming picturesque" (p. 230). On life afloat as against life ashore (the nod to Dr. Johnson is one of several in the novel): "If a ship be to a seaman a prison, with a chance of being drowned, what, after all, is his cot to the labourer, but a prison, with a chance of being starved? -a better chance too, as affairs go, and a worse prison" (p. 50). On Attorney Limp's intellect, small but active: "It was like a swivel-gun ... as young Percival Plug once remarked, not carrying heavy metal, but always capable of being brought to bear anywhere at a moment's notice" (p. 148).

In length as in quality, King Dobbs was a much more substantial novel than its predecessors, running to approximately 100,000 words. Singleton Fontenoy, its successor, was a standard "three-decker" novel, the most ambitious and the most nearly unified of Hannay's narratives to date: the culmination of the first phase of his career as a writer of fiction.

Again one notes a strong autobiographical element. Like Hannay, Fontenoy joins his line-of-battle ship as a midshipman at Sheerness. The Patagonian follows the same route to the Mediterranean as the Cambridge; like the Cambridge, too, she arrives on the "station" in the summer of 1840 and is immediately ordered to join the Syrian operations. Singleton Fontenoy sees a great deal of that part of the world during his tour of duty; he is eventually transferred to a Symondite brig, on which he spends his happiest days afloat; and ends his naval career after being unjustly court-martialed for a Maltese escapade.

As in King Dobbs, there is a romantic strand in the plot, but this one is much more significantly connected with the central line of action. Fontenoy himself is involved in all the love affairs in the novel, becoming infatuated successively with the sister of a boyhood friend, the daughter of his headmaster (her name is Lalage Helot!), and a half-Greek, half-English girl whom he meets on his Mediterranean travels. However, the real love of his life, for whose sake he 
is court-martialed and whom he eventually marries, is his cousin Ivy Welwyn.

These romantic attachments and Singleton's peregrinations, physical and spiritual, are all related to a theme-the first and really the only theme to figure prominently in Hannay's fiction: a sensitive young man's quest for faith in a faithless, materialistic age. What that faith will ultimately be one can easily guess on noting that the epigraph to Book I is taken from Sartor Resartus: "Often we would condole over the hard destiny of the young in this era: how after all our toil, we were to be turned out into the world **** no existing thing that we were trained to Act on, nothing that we could so much as Believe." When read in the sense that Hannay obviously intended, even the epigraph of the whole novel, which appears prominently on the title-page of each of the three volumes, takes on a special Carlylean significance, although its author is Rousseau:

Employons à nous rendre bons et heureux le temps qu'ils perdent à chercher comment on doit l'être, et proposons-nous de grands exemples à imiter plutôt que de vains systèmes à suivre.

J'ai toujours cru que le bon n'était que le beau mis en action.

And the concluding words of the first chapter not only sum up the spiritual problem of the young protagonist at the beginning of the action, but also point to its eventual solution: "Singleton was just then in an intellectual crisis. He had begun to doubt the infallibility of Paley, and had not yet met with the writings of Carlyle!" (I, 13)

Fontenoy rejects the complacent orthodoxy of his father, a stolid country gentleman and county magistrate. He is repelled by the pedantry of his tutor Trochee and his headmaster Helot. He can find no spiritual sustenance in the opportunistic radicalism of his friend Frederick Lepel, and considers the Puseyism of Lepel's acquaintance Mr. Bones of Oriel College fussy and ludicrous.

"This is the eve of St. Kilderkin," said Bones, of Oriel.

"Indeed," said Lepel, "what did he do?"

"He built an abbey."

"Did he pay for it?" asked Lepel.

"This is an age without faith," said Bones, opening a pie...

Fontenoy looked curiously up. Something of this sort had floated through his serious mind, at times. He had begun to feel the want of the 


\section{James Hannay}

age; - a sense of loneliness in life's journey had visited him occasionally. He turned to Mr. Bones.

"You express ideas, I have sometimes thought of," he said. "This absence of Faith-do you think it merely temporary, or the natural result of the exhaustion of traditions, and the prelude to a new organization of spirituality?"

"Exhaustion of traditions!" exclaimed Bones, pausing horrified, in the dissection of a partridge, and holding the entire bird on his fork, suspended in air.-"God bless me! Read St. Kilderkin, born A.D. 960, died A.D. 1019! We have published him in ten folio volumes."-Here Bones made a motion to cross himself, and the bird tumbled on his plate ( $I$, 27-28).

When Singleton strikes up a friendship with Welwyn, a mate aboard the brig Viper, his mal du siècle becomes more rather than less acute: though Welwyn's heart is in the right place, and young Fontenoy is strongly attracted to him, Welwyn does not offer any explicit practical guidance to his protégé, for he is "one of those melancholy idealists who, finding nothing in real life that satisfies their aspirations, reject what they can get, and live among their own fancies. They are discontented without being cynical, and though solitary, are not misanthropes. They are favourable to the movement of the age, but shrink from the participators in it; they love their friends, but go little near them. They read and meditate a great deal, and sometimes write, but will not publish.... If they have a weakness, it is quoting Carlyle and Emerson, and, poor fellows, they care for no luxury but a pipe!" (II, 33)

In Malta, Singleton Fontenoy becomes seriously interested in Roman Catholicism as a way out of his spiritual difficulties, stimulated by the fact that his current sweetheart, Welwyn's sister, is a devout Catholic, and prodded by the exertions of Father Adda, a sympathetic but wily priest. He nearly succumbs to Father Adda's enticements, which appeal to him for the same reasons the medieval Catholicism of St. Edmundsbury appealed to Carlyle:

An immortal being must have some immortal food, and cannot exist on the vulgar supplies of the world's day; and therefore it is, that a curse will rest, and does rest on the nation or state that has nothing to offer to the young, but mechanical work, meanly rewarded. A nation where the word "saint" is a nickname,-which believes in no enthusiasm-which holds the religious man to be the greatest infidel of all-such a nation 


\section{LONDON: THE EARLY YEARS, 1845-1850}

may enjoy the fatness of a snail, but can only expect the honour of one. If he who lives by the sword must die by the sword, so he who lives by the "till" shall die by the "till"-die to great ideas, and die to pure faith. Every human being above the class who seem born without souls, or born spiritually blind, finds the necessity of a divine belief. If none such be inspired by those about him, or inhaled from some noble example at hand, he grows up vague and discontented; perhaps takes to the nearest mumbo-jumbo, or gets whirled into an unhealthy cloud of mysticism, through which what natural light is in him beams dimly and unprofitably (III, 199-200).

However, there is still something missing: Singleton's assent to the blandishments of Rome remains, in Newman's terms, "notional" rather than "real." Providentially, he meets "a crack scholar and writer" who recognizes the young man's incipient Romanism for what it is and asks him "if he had seen any of the works of Carlyle." When Singleton replies that he has not, the scholar urges, "Read Carlyle, and see what you think of things in general, then" (III, 229). Fontenoy follows this suggestion and finds in the teachings of Carlyle the spiritual haven for which he has been seeking. Before long he writes Welwyn from his new berth on the Sybarite, a "hell afloat":

This life does me good: it is rugged as a path on the Alps; but in the silence and the solitude of the waters there is great healing. There is a noble beneficence in work. ...

I have not much time, on board here, for reading, but I have a few choice spirits in my cabin. ... I read C. Great in what he teaches, great in what he suggests, greater than all in what he inspires-that man has called from the depths of my being what good lay buried there, with a voice as 'twere the trump of a resurrection angel! ... Have you read Sartor Resartus? What glances of insight-what solemn music-what rays of true beauty and tenderness are there!...

But I must break off; we are going to bend new sails, and the foreyard wants looking at (III, 260-62).

On the last page of the novel, we see Singleton Fontenoy, now happily married to Ivy Welwyn, as a thoroughgoing convert to Carlyleism, absorbed in a newly published Latter-Day Pamphlet. This conversion, of course, is abundantly prepared for by the numerous Carlylean touches which occur throughout: the glorification of faith, the aristocracy, the Middle Ages, and real Heroes like Admiral 


\section{James Hannay}

Blake, Admiral Collingwood, and Mehemet Ali; the scornful ridicule of modern democracy, commercialism, and mock-Heroes like Sir Booby Booing, Captain Pannikin, and Captain Kraggles, M.P.

This theme of quest gives to Singleton Fontenoy a kind of unity, but one which is frequently strained almost to the breaking point. For example, Hannay relies heavily on coincidence to advance the action of the novel. Singleton's relationship with Ivy and Welwyn, who turn out to be his cousins, is replete with clumsily handled accidents, and other situations place great demands on the reader's credulity. By the end of the novel, Hannay himself seemed to have become aware of this difficulty, and uses the words of his protagonist to defend himself indirectly against those who would charge him with incompetent plotting. When Singleton is able to re-establish his legitimacy (which his father has rather inexplicably begun to question broadly) as a result of a happy coincidence, he writes to Welwyn: "This Cardinal Pira-this strange old man, whose acquaintance I made by an accident-was the priest who performed my father's marriage ceremony! ... People will say that this stroke of fortune was by an almost incredible incident. Well, it is natural for the common-place to believe in the common-place! Be it so" (III, 257-58).

There is in Singleton Fontenoy the same stylistic unevenness which mars the earlier books. The numerous love scenes make rather painful reading, and passages meant to convey the flavor of rapid action gallop along in a breathless, abrupt prose which eventually becomes disconcerting. Frequently, as in the chapter devoted to the plague aboard the Viper, the genuinely pathetic and the merely maudlin coexist at such close quarters that they are almost indistinguishable from each other. Much of his account of the affliction of a young midshipman, for instance, is affecting, but one cannot quite surrender to its pathos.

Simms woke up suddenly, and then recovering himself, shook the sleep from him as a bird shakes water from its wings. His face seemed somewhat changed. It had a pinched look, and was as pale as an unripe peach.

"Where have we been?" he asked, abruptly.

"Been?" asked Singleton, in surprise.

"I thought we had been somewhere together," said Simms. "-I must have been dreaming."

... He picked up the silk neck-handkerchief which had fallen off his 
neck while he was lying down, and flung it carelessly round. It got twisted in some way behind. He asked Singleton to tie it for him.

Singleton jumped up to do it, stepped behind his friend, and disengaged the flowing black silk. As he did so, he saw what made sickness creep from his heart to his cheek. On the white neck were two black spots, like drops of stale gore-the boils that mark the pestilence....

Singleton swallowed his first emotions as one does a nauseous drug, and stood silent and still. He mechanically went on tying the handkerchief, but his fingers trembled.

"What's the matter, Fon?" asked Simms.

His careless question-the soft, boyish tones in which he spoke, and which were associated in Singleton's mind with happy days and gay hopes-made him completely lose his self-possession. He burst into tears, and his eyes were pained with their hot stream. He threw himself on the cushioned lockers, and wept aloud.

"Good God, Fontenoy!" cried Simms, in astonishment.

Brunt entered the berth as he did so. But, though the aspect of Fontenoy was the most extraordinary, and apparently the most alarming of the two, Brunt's eyes rested on Simms' face. Fontenoy sat up, and contrived to convey by his eyes to the assistant-surgeon something of what he dreaded.

"You're looking palish, my boy," said Brunt, carelessly, to Simms. "What have you been eating? Here, let me tie that handkerchief of yours for you."...

"Poor Fon has been crying about something," said Simms, kindly and smiling. They were the last words Singleton ever heard him say. The pestilence had been working in his blood, and soon giddiness and nausea came on, and his soul began to choke in the ghastly vapours of death (II, 177-79).

However, Hannay still seems to be most comfortable in his accounts of naval customs and conversations. The following description of early morning in a gunroom, which culminates in one of the free and easy shipboard discussions which Hannay does so well, is typical:

the cockpit was just beginning to stir into life; gentlemen were stationing themselves before their toilette apparatus on the amputation-table; queer little looking-glasses were suspended here and there, in which flickered the reflection of the yellow light of lamps; shouts were heard of "pass the word for Tomkins-pass the word for Higgs," as each riser required his marine valet. There was a splashing of water,-an odour of 


\section{James Hannay}

bear's grease,-a rattling of chest lids. One youth, with nothing on but his trowsers, was standing under the hatchway, poking his head up the wind-sail to monopolize as much air as possible; a kick soon displaced him, we may be sure. Presently comes a thump; a cartouch-box, or perhaps even a bayonet, rattles down from the lower-deck, where the marines are cleaning their accoutrements; then a curse and a grumble; a light cloud of pipe-clay floats in the air. Anon comes a sharp pop,-it is sodawater,-the cork strikes Dalton, who is trying to shave at the risk of his life; there is a general laugh. In a short time, some dozen or so of the mids are assembled round the amputation-table; conversation begins (III, 168-70).

And his estimate of the guard ship wardroom mess shows the pithy, epigrammatic side of his prose at its best. The group includes "various respectable old fogies": "middle-aged Captains of Marines, Masters of old standing, Lieutenants who pretend to be somebodies, and young Marine officers who are nobodies. They talk of politics without knowledge, and of women without principle; they criticise clubs to which they don't belong, and talk of lords whom they don't know; they are great about second-rate hotels, and discuss old anecdotes over new wine!" (I, 228-29)

In reading Singleton Fontenoy, the literary historian is struck by the strong Carlylean tinge of the novel. The critic notes with interest Hannay's partially successful attempts to impose structure and unity on heterogeneous materials. But the reader of 1850 surely paid much more attention to the hero's naval and amorous adventures and left prolonged speculation about the book's theme and the author's technique to such pedants of the future as might care to concern themselves about these matters.

Hannay's first five books brought him modest financial returns and, more significantly, won him an audience for his work. As he later recalled in his diary, he was paid $£ 5$ for Biscuits and Grog, $£ 10$ for A Claret-Cup, $£ 15$ for Hearts Are Trumps, $£ 60$ for King Dobbs (a much longer work than any of its three predecessors), $£ 25$ for the first edition of Singleton Fontenoy, and $£ 30$ for the copyright of that novel. The monetary pressures which persistently bedeviled Hannay may have been responsible for his accepting the lower remuneration for Fontenoy; also, he was dealing with a major publisher for the first time, Henry Colburn, to whom he later referred 


\section{LONDON: THE EARLY YeARS, 1845-1850}

scornfully as that "galvanised toad... who swindled me in re Fontenoy." 27 In any case, he was making his way.

Critics, and presumably readers at large, were paying attention to these tales. Even the first of them, Biscuits and Grog, modest as it was, attracted a handful of appreciative reviews. The Literary Gazette held that it belonged "to the Thackeray school, and [was] not unworthy to take a high class in it." The reviewer praised Hannay's "spirit and talent" and compared some of his naval passages to "old Tobias Smollett" (6 May 1848, pp. 307-08). Although emphasizing that Hannay was working in a distinctly minor genre, the Athenaeum's critic approved of Biscuits and Grog's "piquancy and liveliness," its "dashing, pungent, vivacious style," and Hannay's "turn for satiric portraiture" (4 May 1848, p. 242). The first reviewer to compare Hannay to Captain Marryat, apparently, was the critic who noticed Biscuits and Grog in the Nautical Magazine. He also warned Hannay "to disguise his persons more completely than he has done in the little jeu d'esprit before us; or his work will be excluded" (January 1849, p. 53). The transparency with which Hannay cloaked the identities of many of his targets in his first volume does seem to have caused him some trouble; for he wrote, somewhat ambiguously, in the preface to his next book that "CIRCUMSTANCES make me think it right to take this opportunity of stating, that I have not availed myself of the privilege of writers of fiction, to use actual facts and persons as a basis of narrative and character, the least beyond the usual extent" (CC, p. 54).

Among the admirers of King Dobbs was Thackeray, to whom Hannay had dedicated the book (the novel originally appeared in parts), "with the respect and affection due to his genius and character." Thackeray wrote Hannay on 29 June 1849:

The publisher hasn't sent me the king, and I ordered it of my bookseller here who forgot me: so that I'm as yet without a knowledge of any but No. 1 part of $w^{\text {h }} I$ thought was excellent-I hope the rest is as good A naval captain told me of it the other day lauding it highly but saying the author was too savage. I suppose we all begin so-I know one who did: and who is sorry now for pelting at that poor old Bulwer \& others, but it was in the days of hot youth when I was scarcely older than you are now. ... I am very much pleased indeed to have your good opinion and that you like and appreciate what I do. I wonder whether I shall 


\section{James Hannay}

ever set up a flag as I often thought of doing-if so, and you were inclined to serve I have always thought I would like to have you for a lieutenant.2s

Though reviews of unpretentious books by little-known midVictorian novelists are difficult to come by, I have located ten of Singleton Fontenoy, at least one of which, that in the Critic, may fairly be called enthusiastic. "Singleton Fontenoy is emphatically a remarkable novel. It is one of that order which makes its author's name at once; after which the public expect with confidence new works from the same hand, and good works with certainty: such a book as grows ineradicably into the reader's idea of the writer, and becomes the distinctive idea of his individuality. Several instances of this kind might be specified, and will readily recur to the recollection,-as of Jane Eyre, Pickwick, Vanity Fair, and Contarini Fleming; few who have read Singleton Fontenoy will hesitate in adding one more to the list." After this rather breathtaking opening, the reviewer goes on to praise other features of Hannay's work, particularly his verbal brilliance; though Fontenoy's plot is weakly constructed, there is a "compensating charm" in its "uniform liveliness and polish, and in the delicate completeness with which each scene and character is successively presented" (IX, N.S. [15 November 1850], 544-45). According to a nineteenth century historian of the novel, John Cordy Jeaffreson, Fontenoy had "an immense sale"; "immediately on its appearance," it made a reputation for Hannay, "and placed him in public estimation in the front rank of "naval novelists. " 29 One of Hannay's readers was a man who ordinarily had little patience with fiction or any sort of "light literature": an unexpected consequence of the book's publication was a summons from the sage of Chelsea, Carlyle himself, to call on him in Cheyne Row. Obviously impressed by the philosophical and social implications of the novel, Carlyle startled his young visitor by launching, as soon as Hannay was seated, into a panegyric of the splendid and dangerous life of the sailor-a life of which Carlyle knew nothing. ${ }^{30}$

Later that year (1850), Hannay had another opportunity to express the Carlylean sympathies which had so strongly colored Singleton Fontenoy. Between February and August, Carlyle published his series of eight Latter-Day Pamphlets, in which he railed against the abuses of the "New Era" in England with a fiery eloquence that was unusual even for him. None of the ideas he expressed 
in these Pamphlets-his longing for a government by Heroes, his contempt for parliamentary democracy and laissez-faire industrialism, his scorn of "the deep-sunk condition of the English mind ... in all spiritual or moral provinces" 31 -was really new: what astonished Carlyle's readers and offended even some of his friends was the intemperate tone he adopted. Some of his specific suggestions, too, provoked consternation, such as the half-expressed hope that Peel might be the man, "Hercules-like," to clean out Downing Street, "that stable of King Augias, which appals human hearts, so rich is it, highpiled with the droppings of two-hundred years." 32

Among the harshest critics of the Latter-Day Pamphlets was the reviewer for Blackwood's Edinburgh Magazine. His critique, which (appearing in June) was confined to the first four Pamphlets, is a curious document. ${ }^{33}$ It begins and ends with the strongest abuse of Carlyle the man, his ideas, and the language in which he expresses them. "If Mr. Carlyle feels that his vocation is political ... he ought to endeavour in the first place to think clearly, and, in the second, to amend his style" (p. 657). "These pamphlets, take them altogether, are about the silliest productions of the day..." (p. 657). Their author, who furiously lashes out in every direction against shams and quacks, is himself a notorious "Phantasm of the species which he is pleased to denounce" (p. 642). Insofar as Carlyle's deranged notions make any sense, they are deeply subversive of hallowed institutions, calling into question as they do the basis on which the authority of "the Monarchy . . . the laws, the Church, and the Constitution" rests (p. 646). But embedded in all the hostility is some grudging praise-largely inspired, it is clear, by Blackwood's protectionist, Tory sympathies. For example, the reviewer (who claims to see an apostate Whig in Carlyle) gleefully uses some of Carlyle's evidence to show how Free Trade has brought pauperism to Great Britain, and quotes extensively, with amused condescension, from Carlyle's more heated attacks on Liberal policies.

The Blackwood's review evidently enraged Hannay, since he responded to it with a pamphlet, Blackwood v. Carlyle, in which he attempted not only a point-by-point refutation of the reviewer's arguments, but a general vindication of Carlyle's whole outlook.

He began his rejoinder by casting aspersions on the reviewer's capacity for his job of assessing Carlyle. 
A sturdy violent Tory Journal-grown old in bigotry-whose tone is habitually flippant and violent; how could it be supposed likely to weigh justly the claims of such a man? How could the writer go to work to study the writings of such an Innovator with any chance of understanding him? The primary condition of understanding anything is a certain willingness to do so, which the desire to prove the said thing, a lie, beforehand, must utterly defeat. Imagine a native of Epirus, in old times, having heard it generally reported that an oak in the forest of Dodona has uttered a sensible oracle. He sets off to the forest, and instead of listening commences slashing at the tree with an axe! Gods and men would pronounce the native of Epirus a blockhead, and just such a blockhead is the man who in similar fashion slashes at Carlyle, in the June Blackwood! (pp. 4-5)

This strain of violent argument runs through the whole pamphlet, in which Hannay repeatedly refers to the reviewer as an ignorant and corrupt ape who could not possibly understand a noble soul like Carlyle and who would distort his ideas for pay if he could understand them. ${ }^{34}$ "I grieve to use strong language," Hannay wrote, "but we have had no honest pamphleteering lately- (perhaps not since Swift's time, till lately)-and I mean to try to restore it" (p. 30).

Still, Blackwood $v$. Carlyle is far more than mere vituperation: Hannay neatly disposes of his adversary's case with all the cogency and eloquence of the polished debater. Carlyle is not "practical"? This is the old "stupid and prejudiced" notion "that that only is 'practical' which can be measured or eaten. Show us it's net result in a marketable form, the people say, and we will recognize it!" ( $p$. 6) The "Hebrew Prophets," the "Thinkers" and "Singers" of every age-all are impractical in this narrow sense, yet how much more profoundly their ideas have changed the world than the composite busy-ness of the billions of intensely "practical" men.

Carlyle's denunciations of shams are incomprehensible? We must be hypocritical indeed to ignore the trickery and deception that infest every corner of public life: "a King that does not govern, a Lord that is no Law-ward, a Bishop who is not an Overseer of the Church of God, how are these less 'Shams' than a kettle that will not boil, or money that will not feed the critic for lying and apish tirade!" (pp. 10-11)

The reviewer's implication that Carlyle is a renegade Liberal 
raises the question whether he ever read Carlyle's earlier works or simply "judged of them from the hearsay report of somebody as stupid as himself" (p. 15). For even in Sartor Resartus, a dozen years before, Carlyle had denied that the ballot box would ever yield a permanent solution for the ills of mankind and insisted that in government by Heroes rested the only hope of human achievement and progress. Moreover, conventional political labels do not fit an unorthodox seer like Carlyle who rises above mere party squabbling.

The Blackwood's critic similarly demonstrates his insensitivity when he denounces Carlyle's historical writing as "jargon." Hannay takes specific passages from The French Revolution, the particular target of this aspect of the reviewer's attack, and shows by comparing them with characteristic passages of Tacitus that Carlyle's style is singularly noble, penetrating, and passionate, the work of a true poet. "Man's life not being made for pedants, nor of pedants, can never be described by that class of men. Being on the whole wonderful, infinitely various, full of terror and beauty, it will require to be described by the like. Nor can the Universe be adequately 'reviewed' at any amount per sheet; and Histories founded on that process will in due time be thrown into Time's waste-paper basket" (p. 25).

To show that Carlyle's plea for government by the "Noblest" is not mere wild-eyed posturing, as the critic insinuates, Hannay appeals to history. "Who can govern but the Noblest?" (p. 28) What sort of men "set us fairly up in the world long ago, with a handsome capital of Industry, Order, Reasonable Justice and Toleration, to Work in peace with, and a Bible to help us to Worship" (p. 32)what sort of men but Heroes and the "high intellects" who served under them?

In closing, Hannay directs "a word to my friends and compeers, the youth of England, those who, like myself, are seeking everywhere for spiritual life and light, and who have this question to determine for themselves, what benefit they may derive from the study of Carlyle's writings?" (p. 35) Carlyle's teachings, he reminds them, are essentially religious: not in the sense we give the word when we speak of empty creeds, dogmas, and rituals, but in the way his books lead us to look at God, the world, and ourselves with new wonder. It is only when we have grasped the poetry, the religion in Carlyle's work-his "natural supernaturalism"-that we can properly under- 


\section{JAMES HANNAY}

stand it and soundly refute the arguments of those men of limited intellect, insight, and integrity, like the Blackwood's critic, who see nothing in Carlyle except what arouses their scorn and contempt. Carlyle, Hannay reminds his young contemporaries, is a great prophet and teacher whose words we ignore at our peril in the present age of spiritual exhaustion-a prophet and teacher, we note today, whose influence on Hannay's own work becomes ever more marked as his career continues into the 1850 's. 


\section{Chapter III: London: the Successful Decade, $1850-18 \dot{b} 0$}

In one of his "personal and auto-biographic" diary notes, Hannay recalls 1851 as the year in which he "first began to form and keep up a connexion as journalist with some periodicals of status and influence." Shortly after the success of Singleton Fontenoy and Hannay's public declaration of his Carlylean sympathies, his talents were being sought with increasing frequency by the editors of newspapers, magazines, and reviews, including some of the most colorful and eminent publications of the mid-nineteenth century. During the 1850's, Hannay's contributions appeared in roughly a score of these.

An interesting progression is discernible in the nature and the placing of these contributions. Early in the decade, when the memory of his polemical journalism and his naval novels was still fresh, most of his magazine work consisted of satire, fictional and non-fictional sketches (usually dealing with naval matters), lightweight essays, and miscellaneous reportage; by the end of the decade, however, he was not only a regular editorial writer for a highly successful London paper but a frequent contributor of substantial reviews to leading periodicals like the Athenaeum and the Quarterly Review.

Ironically, one of the first magazines to make use of Hannay's services as a satirist was Punch-the same Punch against which he had waged such relentless warfare not very many months earlier while writing for Pasquin and the Puppet-Show. But such drastic changes of allegiance were common in the world of mid-Victorian journalism, and the men in charge of Punch certainly recognized a clever satirist when they saw one. As Spielmann suggests, ${ }^{1}$ Thackeray may well have helped his young friend and admirer to gain entry to the Punch circle, as he was to aid him on several later occasions in obtaining literary employment.

At any rate, between April 1851 and April 1853 Hannay contributed nearly a hundred pieces of one sort or another to Punch. Some of these were mere paragraphs, punning reflections on current affairs; others ran as long as seven hundred and fifty or a thousand words, at that time the maximum length of Punch articles. Like other Punch writers, Hannay had his sharp-tongued say on such controversial political figures as Lord John Russell (an old target from 


\section{James Hannay}

Puppet-Show days) and Disraeli, and on such weighty public questions as free trade, Puseyism and the re-establishment of the Roman Catholic hierarchy in England, the Great Exhibition and the "beastly Crystal palace," sanitary reform, Kossuth's visit to England, and Louis Napoleon's coup d'état.

In much of Hannay's work for Punch, however, his own experiences and interests played a large role. His naval background still furnished him with considerable material, as, for example, in the series "Leaves from the Log of H.M.S. 'Prince of Wales," "Lectures on Yachting," "Our Admiral on Half-Pay," and "Hints to Young Yachtsmen." His interest in heraldry, which began at about this time, ${ }^{2}$ was reflected in a series of "Heraldic Fragments," facetious explanations of certain aspects of that science which Hannay made the vehicle for some pungent social satire.

When you marry an heiress, you quarter the arms of her house-when she has money, you quarter yourself in her house, likewise (XXI, 43).

There are a lot of imaginary animals borne in Heraldry; and perhaps the most imaginary of all are the warriors named as the founders of families in the "The Peerage." Too often, the griffin or the unicorn are as really historical as these persons (XXI, 56).

The griffin, the heralds tell us with a very amusing candour, is a "chimerical" creature. He is described "with large ears and no wings." But we are far from being sure that he is so very chimerical, after allif these be his proper distinctive characteristics. Poets and politicians of the description are still found in Europe. And perhaps it is some real modesty that induces people who have no right to arms, to assume griffins, as they not unfrequently do (XXI, 145).

... the charming feature about Heraldry now-a-days is just this inapplicability of everything about it to any use. All the beasts look as if they were cramped up by some Wombwellian arrangement; lions are drawn of imbecile appearance; and warlike birds appear to be stuffed. Some people, indeed, looking at these representations, fancy they are "all stuff" in a still more comprehensive sense; but perhaps they are just as like the real animals as their bearers are to the original people who adopted them! And so, perhaps, Heraldry may be said to be somewhat typical still (XXI, 67).

Much of Hannay's work for another popular weekly magazine 


\section{LONDON: THE SuCCESSFul DeCADE, 1850-1860}

during the early 1850's dealt with naval matters. About half of the twenty articles he wrote for Dickens' Household Words concerned sailors, ships, the Royal Navy, and the merchant marine. ${ }^{3}$ Some of them were mere reportage: accounts of Christmas at sea, of the London docks, or of a visit to Admiral Collingwood's old ship, which had been turned into a floating hospital for sailors. On other occasions, Hannay was moved by the crusading spirit which so often characterized the magazine. When a clumsy and mismanaged pension plan for merchant seamen had to be terminated by act of Parliament after running up a deficit of over $£ 370,000$, an article written by Hannay urged that a substitute scheme be put into effect promptly "and so help to efface the memory of the blundering and imbecile system just come to a close" (IV [13 December 1851], 276-77). In another essay, Hannay used the humorous memoirs of an imaginary disaffected naval officer, Captain Jeremiah Jiggs, to call attention to some of the grosser abuses then prevailing in the Royal Navy, primarily the short-sighted conservatism, the ignorance, injustice, and inefficiency of the civilian bureaucracy which controlled the service, and its refusal to tolerate criticism of naval operations by those in the best position to criticize (II [15 February 1851], 502-04).

Frequently, these naval articles written for Household Words gave Hannay an opportunity to express some of his pet views. For instance, the appearance of Hepworth Dixon's biography of Robert Blake in 1852 prompted Hannay to eulogize the admiral, one of his favorite Heroes, in a long essay. But he esteemed ordinary seamen, too. In an account of a sailors' home founded by private philanthropists to give mariners a decent place to live at reasonable rent between berths, Hannay lavished high praise, with strong Carlylean overtones, on the character of the seafaring man. "The fact is, that a sailor is generally in a true, real position-has certain work to docertain people to obey. There are no false struggles, no sham pretensions, afloat. Every thing is determined by book and order.... It is the continual value set on reality at sea, that gives him independence and self-possession. The ocean knocks him about till he is rounded like a pebble. Salt water keeps character wholesome, as it preserves beef" (II [22 March 1851], 613-14).

Hannay's work for Household Words was not, however, restricted to nautical subjects. One essay, "Lambs to be Fed," was an account 


\section{JAMES HANNAY}

of juvenile vagrancy and its possible remedies, inspired by a recent study by Mary Carpenter, Reformatory Schools. ${ }^{4}$ His sketch of the history of coffee-drinking turned into an exposé of the widespread adulteration of that beverage with chicory by English vendors. In other articles, Hannay enlightened Household Words readers about such diverse subjects as election abuses, Kew Gardens, Mormonism, an illustrious London eating-house, the history of English song, the engraving and printing of postage stamps, ${ }^{5}$ the arrangement of graves and the composition of epitaphs, the Scottish antiquary Joseph Train, and the Renaissance scholar Isaac Casaubon.

Dickens seems to have been satisfied with Hannay's writing, though there is an occasional acid comment about Hannay's style in Dickens' correspondence with his sub-editor W. H. Wills. "I wish Hannay would not imitate Carlyle," Dickens complained on one occasion-a complaint which the alleged offender would probably have taken as praise. "Pray take some of the innumerable dashes out of his article," he instructed Wills in the same letter. ${ }^{6}$ Despite such objections, Dickens could not have been very much disturbed by any infelicities in Hannay's work: Hannay wrote for Household Words until 1855, by which year he had plenty of other employment, and when Dickens founded All the Year Round four years later Hannay was one of the early contributors.

Unlike the miscellaneous pieces he wrote for Household Words, Hannay's half dozen All the Year Round essays dealt with a single theme: Great Britain's need to maintain her naval superiority in an age of steam, when France, and to a lesser extent Russia, were bending every effort to surpass her in maritime strength. Drawing heavily on his own naval experiences and on his personal investigation of the facilities at Portsmouth and Cherbourg, conducted while these articles were in preparation, Hannay presented in All the Year Round a judicious assessment of the country's naval position and a program for outstripping England's Continental rivals. The Admiralty, full of politically motivated amateurs, and woefully inefficient by contrast with its French counterpart, must be reformed. The problem of manning the Navy with a stable force of experienced and reliable sailors must be solved. The training of naval officers, already vastly improved since Hannay's time as a midshipman, must be stiffened still further, primarily by making the course of study longer and by includ- 
ing more non-professional subjects like history and international law in the curriculum. Finally, the authorities should make greater use of modern advances in the techniques of buildings ships and fortifications. The problem, after all, was crucial.

It is not enough that we should be safe from invasion; we must not be outstripped in political importance, we must not be liable to be pushed aside from our first-class position, in any part of the world where our flag flies or our language is known. We are apt to forget how much our national importance depends on our downright strength, and that if we are strong by dint of being rich, we are rich, and originally became so, by being strong. Losing our naval power we should lose our colonies; then, by degrees, our trade; and of a certainty, sooner or later, our safety at home. It is not a question that will bear trifling with, and he who pooh-poohs our naval preparations is really contributing to our ultimate weakness in every other department (II [24 December 1859], 198).

While Hannay's work was being published in Household Words in the early and middle 1850's, he was also supplying naval sketches to the United Service Magazine. Almost all of these were semi-autobiographical and went over ground which Hannay had already covered in the earlier naval novels, principally the adventures and misadventures of high-spirited young midshipmen on the Mediterranean station. The protagonists of many of these stories are strongly reminiscent of Hannay, especially Scrymgeour Forbessy and Maxwell Adair, both of whom are fiercely proud of the ancient families to which they belong, though these families are no longer what they were in better times. Like Hannay himself, Adair was descended from the Maxwells; his account of his court-martial, as we have already seen, ${ }^{7}$ parallels what is known of Hannay's Maltese experiences.

These United Service Magazine pieces (the best of which were collected in the volume Sand and Shells in 1854) again put before the reader such familiar characters as Singleton Fontenoy and Sir Booby Booing; they also re-emphasized and expanded Hannay's neoCarlylean notions about the alarming decline in quality of Britain's leaders. The ancient families of "blood and culture" had lost power, both absolutely and in relation to such prominent nonentities as the foppish Snigsbys and the parvenu Fitz-Gubins (who had been known in their not very distant and not very illustrious past by the less dis- 


\section{JAMES HANNAY}

tinctive appellation of Gubbins). It was not that Hannay was against the common man: rather he was disturbed about the consequences which were sure to ensue if these people of mean endowments masqueraded as something they were not and attempted to seize a position in society which they were totally unfit to occupy. Adair's closest associate on his voyage from Malta to Gibraltar after his court-martial was the ship's carpenter-a pleasant companion and a decent. straightforward human being.

The man who is what nature made him, and is a complete man in his own proper sphere, he is not the fellow with whom it is unpleasant to live. It is the confounded pretender-the uneasy being who is striving to be something-who is a bore.... We ought to distinguish between true cultivation-which, beginning in the mind, refines from inwards to outwards-and that sort of refinement which is produced on the outside of a man by contact with polite life, but which, while making him presentable in a drawing room, leaves him vulgar in heart, mind, and soul (June 1854, p. 210).

On only one occasion during the 1850's did Hannay take the sort of leading role in the conduct of a magazine which he had played on Pasquin and the Puppet-Show. Edward Wilberforce, a literary nephew of the Bishop of Oxford, had come of age in 1855 and used a portion of an inheritance to which he succeeded to found a shilling monthly, the Idler. Though Wilberforce served as editor of the periodical, which ran for a half dozen numbers, beginning in January 1856, Hannay was a powerful force behind the scenes, giving freely of his advice to his young friend as well as contributing work to the short-lived magazine. ${ }^{8}$

His connection with the Idler inadvertently involved Hannay in a brief mud-slinging exchange like those which had enlivened his early years in journalism. As Hannay's good friend T. E. Kebbel explained the affair years later, Hannay's Bohemian cronies resented his associating with Oxford men like Wilberforce, and "called him a turncoat, and a hypocrite."9 At any rate, while the Idler was being projected, one of these aggressive young professional London writers, Edmund Yates, was preparing to bring out the Train, a monthly magazine very similar to the Idler in format and content. In view of the pugnacity which was so marked in both Hannay and Yates, it was not surprising that a sharp rivalry quickly sprang up between the two 
magazines. It was Yates who took the initiative. In the first number of the Train, in a feature patterned after the famous Noctes Ambrosianae in Blackwood's Magazine, he included the following exchange:

Ap Shenkin.-Who are the people on the "Idler."

Quarll.-Hannay and Co. University-and-water (with a dash of-no, not gin, but a little cheap claret in it). Fellows, who, if you once get into their pillory, will pelt you with Greek roots, like so many cabbage stumps. All.-Shame!

Quarll.-I hope I've hurt nobody's feelings. Pardon a figure of speech. I have the greatest admiration for Mr. Hannay. I am told he only aspires to the appreciation of half-a-dozen literary men. I should say there must be at least five on the "Idler." I should like to make the other one.

Editor.-Hannay is one of your men, Ramesis [sic], who talk like a book.

Rameses.-Exactly; and the only time I ever met him the book he talked like was "Enfield's Speaker" (I [1856], 63).

Hannay correctly identified Ap Shenkin and Quarll as George Augustus Sala and Robert Brough, two prominent members of Yates's circle of contributors, and retorted with a withering and often quoted epigram in the next number of the Idler:

Easy to see why S. and B.

Must hate the University:

Easy to guess why $\mathbf{B}$. and $\mathbf{S}$.

Must hate cold water little less.

While by their works we know their creed

That men who write should never read,

Their faces show they think it bosh

That men who write should ever wash (I [1856], 93).

This was followed in the succeeding number by another attack on Sala:

S. steals from ev'ry modern author's page:

Yet in some circles S. is quite the rage.

"A man of talent, S," they all agree;

"A man of letters;" yes-a man of three (I [1856], 151).

Even Sala's biographer concedes that this sally left its victim incapable of response. ${ }^{10}$ 


\section{JAMES HANNAY}

Though the Idler resorted to considerable sharpness in thrusts like these, it was on the whole a good deal quieter in tone than the comic weeklies for which Hannay had written earlier. Most of the magazine was taken up with biographical, historical, and travel sketches, essays, fiction, verse, and book reviews; contributors included such estimable names in mid-Victorian letters as J. C. Jeaffreson, Shirley Brooks, William Allingham, W. B. Jerrold, E. F. Blanchard, G. W. Thornbury, Sutherland Edwards, Mortimer Collins, T. E. Kebbel, and W. S. Austin.

Hannay's chief tangible contribution to the Idler was a fragment of a novel, Bagot's Youth, which ran to four numbers and was mercifully discontinued after the seventh chapter. Possibly the weakest of Hannay's longer narratives, it is the story of Fulke Bagot, almost predictably by now the scion of an "ancient and gentle" family which finds itself in straitened circumstances at the time he appears on the scene. He grows up in Greece, the son of the British consul in one of the Ionian islands, and eventually makes his way to London, where he falls in with a set of Bohemians and writes for a satirical periodical. This fragment cannot really be called autobiographical, but Hannay was clearly drawing heavily on his own experiences in the Mediterranean and in London's literary Bohemia and did not assimilate this material successfully for fictional purposes. From the interminable genealogy at the beginning to the stiffly handled conversations in the later chapters, Bagot's Youth makes quite unrewarding reading.

In addition to a number of epigrams, Hannay's only other acknowledged contribution to the Idler was "A Letter to an Administrative Reformer," a characteristic attack on the recently founded Administrative Reform Association and one of its supposed stalwart members, Barnabas Blogg, a wholesale pickle merchant. Hannay agrees that there is much amiss with the government of Britain, but insists that her administrative troubles can be cured only by less rather than more middle class democracy. The essay is notable for its eloquent, if somewhat less than convincing, statement of Hannay's philosophy of "blood":

... if you assert that the ancient blood of the kingdom does not produce able men in every sphere of activity, you babble mendaciously. Our two 
greatest seamen are noble, Dundonald and Napier; our statesmen, Derby, Palmerston, the Greys (I take them from all sides), are usually able in exact proportion as they are gentle. Windham and Campbell in the Crimea are of the best stocks. The greatest philosopher living, Sir William Hamilton, is of a ducal family; the greatest poet, Tennyson, quarters Plantagenet; Bulwer, Landor, Thackeray, are of ancient descent. . . . Mr. Disraeli is of the aristocracy of the Jews-the Sephardim; so was Spinoza. We owe our Indian empire to two very well descended men, Clive and Hastings; we owe the best literature of the age to three very well-born men, Byron, Shelley, and Scott.

And here a word of caution. One really great man, such as Byron or Scott, outweighs a whole generation of little fellows; so don't come down on me with a host of every-day notabilities. Ten donkeys don't make a horse; ten geese don't equal an eagle. It is part of the cockney philosophy of the age to believe that everything is in numbers, as if men were like onions, of which two are better than one, and so forth. But the truth is, that the excellence of the world, and the work of the world, belong to a few, who in all the ages govern the many, and lead them and teach them; and the planet would not be habitable if this were not the case. Ask Mr. Carlyle, who, you may be sure, looks on your "Administrative Reform Association" as the greatest humbug of the age (I [1856], 138).

This is, of course, Hannay the polemicist writing; and the strident tone of the letter is determined by the occasion.

Much of Hannay's other work in the 1850's appeared in daily and weekly newspapers. Like his contributions to magazines, it took several forms and allowed him to range freely in the various fields of public affairs and the arts.

For example, in a series of fifteen "Sketches of Radicals" which Hannay contributed to Disraeli's weekly organ, the Press, in 185354, he engaged once again in political satire with strong Carlylean overtones. He anathematized as "Radicals" all those weak, foolish, misguided, hypocritical, or (sometimes) downright foolish people who sought to obliterate established values and institutions and recast British society in a spirit of muddleheaded egalitarianism. As Thackeray had done in The Book of Snobs, but with more venom, Hannay directed his attacks on a number of fictitious characters who personified some of the objectionable ways in which the movement he was opposing manifested itself: targets like Mawker the "Radical Philosopher," Ponto Sparks the "Radical Jester" (writing for a week- 


\section{James HANNAY}

ly magazine called the $\mathrm{Cad}$ ), Bugby the "Radical Historian," Professor Cockroach the "Radical Lecturer," and so on. Most often, as in his sally against the "Radical Female" ("an over-done woman, or an under-done man"), Hannay used ridicule as his primary weapon: "The fact simply is with regard to these high-flying damsels, that they see a great deal existing in the institutions of Europe which is by no means so pleasant to contemplate as moonlight or 'Locksley Hall.' They would like to abolish all evil out of the world, and sprinkle it with rosewater; and I would like to have strawberries for breakfast, only it is winter time, and I cannot get them" (II [7 January 1854], 13).

But a good deal of shrewd social analysis underlies these "Sketches," as, for example, in his demolition of Flambeau, the Continental refugee who now abets the cause of English radicalism:

Fellows who have been kicked out from every capital in Europe, who first plotted revolutions, then achieved them, and then, when they had done that, could make nothing of them, but stood staring at the work of their own hands till their countrymen turned them out in disgust, should be modest and quiet for a little, at all events. But not so. Flambeau and his friends must join here with the knot who are at the head of our agitation, and help them in their miserable parodies of the agitations of the Continent. Perhaps this is natural, but Flambeau should at least consider why we are able to give him an asylum; why we are still in a decent state of prosperity; and what relation the little English crew who affect to "fraternise" with him bear to the immense mass of the English public (I [3 December 1853], 733).

The influence of Carlyle, of course, is everywhere. Hannay repeatedly insists that the "Radical Rank and File" is a woefully small band of rabble: that the great mass of the people still gladly give their allegiance to "the hereditary and traditionary influences." And small wonder; for

what bond is there between the Radical and his leader? In periods of excitement the leader has an influence; but nothing dies so quick. Many a moneyed man, again, favours Radicalism to salve his wounded self-love. But where is his popular following? The labourer owes him nothing-nay, it is ostentatiously put forward that only "supply and demand" is to rule between them. Nothing about this relation appeals to the imagination or the heart of man. With all our "progress," we are a less brotherly and friendly people than we were centuries ago. Is a man a machine, then, 


\section{LONDON: THE SuCCESSFul DeCADE, 1850-1860}

to have oil only that he may work? Is there to be no affection, which, coming from the superior, is repaid with loyalty from below? Now, here is Radicalism's weak point. It exists only in negation, in denial. . . . How can it stand in competition with anything that appeals to the romantic element in mankind? (II [28 January 1854], 85)

Brilliantly as some of these "Sketches of Radicals" still read today, there is, nevertheless, something fundamentally irresponsible about this kind of political journalism. All that Hannay's Tory employers expected him to do was to drive home his satiric thrusts at the radicals and their many unconscious allies, confused Liberals who parroted radical doctrine without knowing it; since it allowed him to give free rein to a number of his prejudices and to work in a literary medium in which he felt thoroughly at home, Hannay performed this job to something like perfection. But it was no concern of his in these essays to point out specifically how political and social abuses might be corrected, to be constructive instead of merely devastating.

Another of Hannay's journalistic connections in the 1850's, however, his most lasting and most profitable one, gave him an opportunity to do just this: to put aside his Carlylean prophet's robe and his comic writer's rapier and engage in serious, temperate, and responsible discussion of public issues. In April 1855, Hannay's old friend and employer Henry Vizetelly asked him to write for a new weekly which Vizetelly and the publisher Bogue were then planning, ${ }^{11}$ an illustrated newspaper designed to undersell the popular Illustrated London News. Hannay consented, and his initial contribution to the Illustrated Times appeared on the front page of the first issue, on 9 June 1855-a leader hailing the impending abolition of the newspaper stamp tax as a vital development in the history of the freedom of the press, one which made possible the existence of cheap papers like the Illustrated Times.

For the next five years, until his translation to greater journalistic glories in Edinburgh, Hannay served as the Illustrated Times's chief political writer, usually turning out two leaders for each weekly number, as well as occasional book reviews and other articles. In these editorials, Hannay was required to comment on the whole broad spectrum of foreign and domestic questions confronting thoughtful Englishmen in the middle and late fifties. At the 


\section{JAMES HANNAY}

Illustrated Times's first appearance, the country was involved in a costly and mismanaged war in the Crimea. This had to be won; a sound peace had to be arranged; and above all the inefficiency and incompetence in the conduct of the war which papers like the Illustrated Times diligently brought to light had to be remedied. During the next five years, there were more military conflicts in India and China, and real danger of war with the adventuring Emperor across the Channel. At home, political institutions, while not exactly tottering, were not responding adequately to the challenge of the times; as Hannay complained in a leader he called "Political 'Struldbrugs," " too much of the responsibility for governing England was placed in the hands of backward-looking old men like Palmerston (I [15 December 1855], 441-42). The existing party system seemed to be disintegrating, and old party labels were becoming meaningless. A way must be found, Hannay insisted in a number of editorials, to get more able men into government. Competitive examinations were a part of the answer; the candidacy for Parliament of enlightened spirits like Thackeray was assuredly a step in the right direction; but ultimately the nation could be capably run only if the general level of culture and education were raised.

On such matters as these Hannay expressed himself with spirit and yet with temperate good sense week after week in hundreds of leaders. By contrast with much of his earlier work, his editorials were remarkably free of personal idiosyncrasy or partisan cant; as the "Preface to Volume First" of the Illustrated Times, which Hannay himself wrote, put it: "Our Politics may be described, in two words, as independent and as English. We have supported the good old constitutional principles against the conceitedness of the destructives on the one hand, and the selfishness of factions on the other." Hannay was no longer engaging in the sort of political satire in which he had indulged in his Pasquin and Puppet-Show days or as recently as in his writing for the Press: his work for the Illustrated Times was serious and responsible journalism at its best.

Of course, many of his old ideas found expression in this work, albeit in modified and softened form. For example, during the great uproar over the case of William Palmer, the celebrated Staffordshire poisoner, Hannay wrote an editorial on "Capital Punishments" in which he insisted that custom and instinct, as well as public 


\section{London: the Successful DeGade, 1850-1860}

opinion, upheld the view that "punishment by death [is] a sad and terrible necessity, with which we are by no means able to dispense" (II [14 June 1856], 426). In developing this argument, Hannay expressed his indebtedness to his old idol Carlyle for its basic premise. But the tone of the leader is reasonable and dignified; there is none of the ex cathedra thundering which the same subject might have elicited from Carlyle himself or a younger Hannay. A leader with the Carlylean title of "Sahibs and Niggers" turns out to be, not a sermon on the necessity of keeping inferior races in check, but a sharp attack on the "habitual brutality exercised by our countrymen towards the natives" in India; this sort of behavior, the leader holds, is not only indefensible on humane grounds, but it also helps to bring about disasters like the Sepoy mutiny and has ominous repercussions on public and private life in England (VII [23 October 1858], 282).

Although Hannay's duties as editorial writer occupied much of his time from 1855 on, his newspaper work during these years was by no means confined to this side of journalism. For one thing, as something of a sideline, he contributed "London letters" to the New York Tribune for three months in 1856 and to the Dumfries Courier irregularly between 1857 and 1860 . Thackeray had introduced him to the proprietors of the Tribune, ${ }^{12}$ and Hannay's long-standing connection with Dumfries, his birthplace, had been reinforced in the spring of 1857 by political events which we shall consider in their place.

The dispatches to New York provided the American reader with a running account of the topics which Londoners were thinking about and discussing in the spring and early summer of 1856: the end of the Crimean conflict, the disturbing revelations of the commission of inquiry into the conduct of that war, and (on a less exalted level, but probably of as much popular concern as the other topics) the sensational murder trial of William Palmer of Rugeley. For the benefit of his transatlantic public, Hannay devoted considerable space to Anglo-American relations in these columns, and with good reason: a serious crisis had developed between the two countries over their respective Central American policies, but, Hannay assured the New York readers, no one in London expected these difficulties to lead to war. In a somewhat lighter vein, he reported on another 


\section{JAMES HANNAY}

source of Anglo-American friction: the refusal of the Master of the Ceremonies to admit an American officer to the Queen's levee because, in that functionary's opinion, the visitor was not properly attired, wearing a black stock instead of a white and appearing without his sword.

A certain amount of literary gossip, too, found its way into these columns: the comings and goings of authors (including Hawthorne, who was then visiting England) and the publication and reception of new books. Some of this gossip was quite personal. For instance, Hannay made no secret of the fact that he was a friend and admirer of Carlyle's, and on two occasions reported the great man's opinions, as expressed in conversation. Carlyle's view of the Crimean War, expounded "to your humble servant as we walked away westward to his house at Chelsea on a fine cold February day," was extremely dim: "It had been rushed into entirely at the bidding of the people, and contrary to the opinions of private thinking men. He added that he had no wish to save the Turk from Russia; that the Turk was 'an ugly, black, sensual fanatic;' that 'he had performed his mission by destroying the dirty, attorneying Greek theology when the sun had become weary of it;' and that ever since, his disappearance from Europe had been the earnest wish 'of Christian men' "' (21 April 1856, p. 6). Nor was Carlyle's opinion of the prospects of European culture in general any more sanguine. "He has often told me that we are living now 'with hell under our feet,' and that all our civilization and prosperity are a thin rind or crust over it, on the security of which we cannot depend" (28 May 1856, p. 6). Hannay made no secret of his animosity toward Macaulay, who was then, he reported, suffering from asthma and smarting under the criticism which his unkind treatment of the Quakers in the History of England had called forth; he referred to Macaulay as "an arrogant, cold, tufthunting kind of man, who makes the common mistake here of fancying that to mix with the aristocracy makes one an aristocrat" (24 May 1856, p. 9). Dickens and his followers, especially Mark Lemon, came in for their share of abuse. When Dickens bought Gadshill Place, Hannay wrote, "his admirers" raised a chorus of "wonder and praise." He continued, depreciatingly: "It is a poor little place enough, I am told, but Dickens' claqueurs are the most faithful alive," particularly Lemon (9 June 1856, p. 3). Several 
letters later, he renewed the attack on Lemon, pointing out the irony of Punch's chiding the Morning Advertiser for being "the organ of the public-house interest"; "the taunt comes oddly from Punchwhich is edited by Mr. Mark Lemon, who used to keep a public-house himself. The said 'public' was called the Shakespeare's Head-though surely a Shakespeare's head ought never to have had so little brains in it" (24 June 1856, p. 6).

The Dumfries letters, which were headed "Gossip from London," dealt much more extensively with literary matters than the dispatches to New York had done; politics and current affairs played only a minor role in them. Rather oddly, it seems today, Hannay often complained in these letters about the dullness of the literature in the period he was chronicling, though at a century's remove it strikes us as exceedingly rich: as Hannay's reports make clear, Carlyle, Dickens, Tennyson, and Thackeray were all active and producing major works, and, in addition, the years 1857-60 saw the appearance of such important books (all referred to, more or less extensively, by Hannay) as Tom Brown's School Days, the first volume of Buckle's History of Civilization in England, On Liberty (which Hannay praised enthusiastically), and Adam Bede, not to mention numerous other titles which Hannay did not have occasion to cite. Leigh Hunt and Macaulay, as well as several other literary figures of less renown, died during these years and had their stature assessed in Hannay's Dumfries letters. Hunt, for example, "was the best belles-lettrist we had; the best 'light literature' man, in the good sense (for there is a good as well as a bad sense), of that phrase of description. His poetry was not strong, deep poetry, but delightfully fresh, sparkling, and playful; and, I think, more genuine, for instance, than Tom Moore's. In the great revival of our poetry which occurred during his youth Leigh Hunt's was like a garden fountain, while Wordsworth's was a deep, slow river, and Byron's played the part of lightning and rain, clearing the heavy air of English thought" (20 September 1859 , p. 4). Macaulay, a man of vast ability despite his dogmatism and his haughtiness, had made a striking impression on the reading public of his day, though not everyone (including Hannay) could agree with his philosophy. In Hannay's view, Macaulay had carried over into his historical writing "the essayist,the parliamentary,-the rhetorical mind"; it was both the strength 


\section{JAMES HANNAY}

and, ultimately, the great weakness of his History that "his style and tone are emphatically those of a reviewer."

The rattle,-the point,-the pungency of his pages are in the long run more wearisome than the rotund stateliness of Gibbon or Robertson, and have less judicial gravity and reliability. His earliest feeling on the subject evidently was that history had hitherto been $d u l l$, and that we must avoid that danger at all hazards. Scott's novels and "Tales of a Grandfather" had prepared the world for lively historical writing, and Macaulay determined to supply it,-and practiced it in the "Edinburgh"; the result is a brilliant history,-but not a final one,-not one accepted as "a possession for ever" by thinking men (3 January 1860, p. 4).

There was plenty of material for literary gossip in London in the late 1850's. For example, Dickens' marital difficulties came to a head in the spring of 1858 and on 12 June Household Words printed his rather mysterious denial of the rumors concerning his domestic "trouble" in a front page open letter to his public. Hannay, writing a Dumfries letter a few days later, found all this very strange and probably quite unwise.

For my own part, I think it was an error in judgment,-because the scandal could never have reached any but a small portion of his large audience,-because inveterate scandalmongers will now say that a mere declaration, which instances no special charges, amounts to nothing,-and because, by so communicating with the whole world, the writer gives the whole world a right to ask, What then is the matter? It was, otherwise, nobody's business to ask, or to know anything whatever of $\mathrm{Mr}$ Dickens's private domesticities; but now they have a claim to be informed that Mr Dickens has separated from his wife, after twenty-two years of matrimony and the birth of nine children. Such is the simple fact, upon which gossiping London accumulated certain false rumours; and until it is known, the manifesto of the novelist is unintelligible, and only serves to set people talking and wondering (22 June 1858, p. 4).

At about the same time, Dickens' young protégé (and Hannay's old rival) Edmund Yates became involved in a controversy with Thackeray, which ultimately drew in Dickens himself. Presumably basing his sketch on observations of Thackeray at the Garrick Club, to which both of them belonged, Yates had published an article on the novelist-Hannay called it a "coarse personal 'description' "-in Town Talk, a weekly which Yates edited. Thackeray was deeply offended, not only by the piece itself but by the circumstances under 


\section{London: THE Successful DeCADE, 1850-1860}

which it originated, and the ensuing conflict caused a great deal of excitement in the London literary world..$^{13}$ As might have been expected, and as his letters to Dumfries made clear, Hannay sided unequivocally with Thackeray against Yates. What Yates had done was "contemptible." "What would your subscribers say to me if I photographed any eminent man of my acquaintance? or (worse still-as in the present case) drew a gross sketch of him from having seen him in the smoking-room or coffee-room of a club? Public gossip-politely done-I hold to be quite fair; it is honestly come byit hurts nobody's feelings. But the other kind! It is the fear of being made the victims of $i t$ that has caused more than one club's members to 'blackpill' literary candidates" (3 August 1858, p. 4). Yates was one of

a miscellaneous crew of writers of tales and farces, buffoons, hangers-on of theatres, jokers of jokes, fellows who never open a book more learned than a French novel, and who write as a street fiddler fiddles-only for the pence-and because they are unfit for higher employment. ... It is from sources as dignified as this that modern literary wars arise: but Job himself would be angry if, while eating his dinner at a club, he caught young Noodles photographing his nose for a penny paper. It is all very fine to tell a man that he ought to despise petty assailants, "best leave him alone," \&sc., but would the preacher of such doctrine himself sleep tranquilly with a mosquito inside his curtains? Would he rest till the little creature had been cracked? Mr Thackeray is one of the kindest men living, as he has proved on scores of occasions; and is far above his assailants and their backers-up; but for the sake of literature itself this Paul Pryish way of scribbling malignant "sketches" must be stopped, and I flatter myself that the source of such things will be more intelligible to your readers from the above observations. The author,

"Renowned by all for writing well,

Although he never learned to spell,"

was a well-known phenomenon in Swift's times, and masses of the "light literature," which swarms at our railway stations is produced by such people now. They detest a writer whose fame, while equally wide, is ten times as high as their own; and their jackals rush eagerly to vex him with their howl (31 August 1858, p. 4).

It would be unfair to Hannay, however, to place undue stress on his role as a purveyor of literary gossip, because, even in his newspaper work, he frequently concerned himself in a serious and 
responsible way with literature per se. Throughout the 1850's he wrote book reviews and literary articles for daily and weekly papers, primarily the Daily News, the Illustrated Times, and the Press, developing talents which he was to exercise on a much larger scale in highly respected periodicals as the decade progressed.

Though all kinds of books came his way for reviewing, perhaps his most trenchant criticism was expended on novels, especially the work of Thackeray; indeed, on the basis of these newspaper articles and his other essays on his friend and benefactor, it seems safe to call Hannay one of the most perceptive contemporaneous commentators on Thackeray's work. ${ }^{14}$

As might be expected in view of Hannay's interest in genealogy, he laid great stress on ancestry in accounting for Thackeray's genius. "Mr. Thackeray is of Saxon descent, and of a landed family settled from the earliest period in the county of York. From that county's families came Swift, and Cleveland, and Dr. Garth, and Pope's mother, and Bentley, so that it has produced its share of the humourists and satirists of England." Whatever Thackeray might have owed to "blood," however, he supplemented by study and cultivation: Hannay constantly paid tribute to the breadth and depth of Thackeray's learning.

Thackeray's most distinctive feature and greatest asset as a novelist was his realism, especially his realistic treatment of men and women and their fortunes in the world. He refused to divide his characters into heroes and villains or to reward the good and punish the bad with unrelenting poetic justice. "The good characters have their share of the weak part of our nature, and vice versa. ... no man has said more severe and Rochefoucauld-like things about human nature-no man has exhibited the tenderer sides of it under simpler and more homely aspects." His "kindly, simple-hearted" people like Dobbin or Colonel Newcome are drawn with admirable fidelity, "from the everyday English life in which they are to be found"; because of his skill and accuracy in depicting them, their more unscrupulous contemporaries, and the social world which all of them inhabit together somewhat uncomfortably, Thackeray's "works will, generations hence, have an historic value, as pictures of what English life was in the reign of Queen Victoria." Though Thackeray is endowed with exceptionally keen insight into the 
general truths of human nature, it is his striking use of appropriate details that gives his people their solidity: "he always has the actual accessories ready, and puts in the points of daily life with copiousness and finish."

Admirable as his individual characters are, it is as a novelist of society that Thackeray excels. "Society, rather than the mere genus homo, is his true field. He has a heart for man anywhere, but, somehow, it is man educated, man living in a highly developed, artificial, social life, that attracts his chief observation." Regency and Victorian society, which he knew at first hand, is, of course, the world which Thackeray renders most successfully; but in Esmond, for which Hannay confesses a strong partiality, he has imparted to historical fiction a high degree of effectiveness which it has not displayed since the early Waverley novels. "His personages wear wigs, but-you do not come away from them, remembering that, as the chief fact.... They are characters, such as the world always has in every agemoving in this particular one, for the time." Thackeray's skill at capturing the flavor of Augustan society is no accident, because the period is one with which he shows a strong temperamental kinship: "He is like an eighteenth century man transplanted into a better age, and flowering in a richer soil." His marked affinity to the writers of Queen Anne's time and their immediate successors is most clearly discernible in his "lucid, conversational, pleasant style, [which] is a kind of new development of the favorite style of the last century."

Hannay's admiration of Thackeray was enthusiastic, but it was not idolatrous; and the reservations he expressed about Thackeray's work strike the twentieth century reader as reasonable. Thackeray's storytelling gift was severely limited. There were areas of life into which he seldom ventured: poetry, romance, sentiment, physical nature; others he never even approached, especially religious or mystical fervor. "In passionateness, in poetic humour, in a certain fairy-like waywardness of imaginative power, and the play of that intensely enjoyable fun which you feel with all your veins like a child-he cannot be compared (and no man knows it better than himself) with Charles Dickens. In quickness of sensibility, tremulous quickness in receiving beautiful, and humorous, and fantastic impressions; in describing the scenery of external nature, and making light and shadow, and the images of leaves, fly across his sunny page 


\section{James Hannay}

-Dickens of course excels him." The sheer bulk of a novel like The Newcomes was unfortunate. "For ourselves, we could go on reading Mr. Thackeray monthly, even if we were spared to ante-diluvian longevity. But in a century or two, what will our descendants do? Will they have the time? Will they-that is, any great number of them-have the resolution to read more than one story of such proportions about a race who will be as strange in their eyes as the Squire Westerns and Tom Joneses, Thwackum and Square, are in ours? ... Every great writer should produce some one brief work-a work that could be read at a sitting for example-and so acquire a chance of being read, as well as of being talked about."

Occasionally, a technical aspect of one of Thackeray's books is troublesome; in Esmond, for example, there is sometimes perceptible "an incongruity ... between the notion of Esmond, which we form, and the remarks which he makes: he having to tell his own story and to speak Mr. Thackeray's censures, too." And, finally (a point which really does not bear on his view of Thackeray's art), Hannay upbraids Thackeray for giving Sterne less than his due in The English Humourists, and for his unfairness, in that work and in Henry Esmond, to Swift.

Hannay's opinion of Dickens as a novelist was decidedly cooler than his view of Thackeray. Reviewing the first number of Little Dorrit in the Illustrated Times, Hannay represented Dickens as a fluent storyteller with a remarkable gift for conveying sensations to his readers who always wrote with a "purpose" in mind. Yet, clever as Dickens undeniably was, he did not develop as an artist: he merely accumulated and turned out more and more material. In his ability to generate thought and reproduce reality, he was as inferior to Thackeray as he was superior to him in "romance": "There is a common notion that Dickens's strong point is real life. This is quite a fallacy. His strong point is romantic and poetic talent-imagination and phantasy-as you will see if you meditate one of his characters, and try and conceive it apart from the halo of fancy, grotesque fun, \&c., which he has thrown round and round it" (I [8 December 1855], 435).

The numerous reviews which Hannay contributed to newspapers during the 1850's dealt with all sorts of books. In addition to fiction, he reviewed volumes of poetry and belles-lettres; in the category of biography, autobiography, and table-talk, he wrote on books by or 
about celebrities like Charles James Fox, Haydon, Sydney Smith, Samuel Rogers, and Leigh Hunt, and he frequently noticed new publications dealing with such favorite subjects of his as Scottish or naval history.

However, in order to arrive at a proper estimate of the state of Hannay's critical powers during this decade, it is necessary to go beyond these newspaper reviews, shrewd and penetrating as many of them are, and examine the more extended essays which Hannay wrote for some of the most substantial intellectual publications of the day, periodicals like the Leader, the Westminster Review, the Athenaeum, and the Quarterly Review. Almost uniformly, these critiques exhibit good sense and sound scholarship, tact and insight; they are written in a lively, sometimes a surprisingly colloquial, style, and they express cogently argued and copiously illustrated judgments with which one finds it difficult to quarrel a century later.

Book-reviewing in the 1850's for periodicals that had attained, or that were aspiring to, eminence involved much more than simply glancing superficially at the merits and defects of the volumes under consideration. Typically, the new book was regarded as a representative of a kind, an indication of a trend, and had to be discussed in terms of the conditions out of which it arose. The result, more often than not, was a comprehensive essay on a broad subject rather than a mere notice of a single title. Particularly in the quarterlies, where the critic had a good deal of elbow room, this tendency to range widely was often carried to extremes: it was not uncommon to dismiss in a very few words the book which was ostensibly being reviewed and concentrate on the larger questions which that book suggested. For example, Hannay's Westminster review of Lord John Russell's edition of Thomas Moore's Memoirs was primarily a history of the relations between men of letters and men of wealth and power from the earliest times to the nineteenth century. Moore himself was mentioned in this essay only as an example of the low state to which literary patronage had sunk in the modern era: "The minstrel came and sang and dined with the modern Baron, and was called 'Tommy;' and his very liking for the Baron's company was thought his weakness in the hall! The whole pretence on both sides rested, in most cases, on falsity. The Minstrel had an eye to the advertisement when he sat down to sing at the piano. The Baron was no Douglas 
or Percy, but the great-grandson of some contractor with a fortune and a title, both the product of jobs. Deduct the upholstery, and the Covent Garden bouquets, and what was left of the splendour of Tom Moore's favourite triumphs that was moral?" (LXVII [April 1857], 522). About this edition of the Memoirs itself, Hannay said only that it was bound to harm Moore's reputation.

Even in the serious weeklies, book reviews dealt not only with the intrinsic qualities of the books criticized but with all sorts of more or less relevant extrinsic considerations. Hannay's review of Lowell's Poems in the Leader, to take one instance, begins with a thorough examination of the state of American literature and the extent of its appreciation in England at mid-century. Sydney Smith's much-quoted gibe about an "American book," he remarks, is now even more absurd than when it was made, for "English editions of American authors crowd our booksellers' windows. Emerson has been reprinted, in whole or in part, in three forms. Hermann [sic] Melville, Edgar Poe, Hawthorne, Dana are well known; Holmes is beginning to be known..." Hannay chides Americans for their literary chauvinism; of course American literature bears strong traces of English influence: why should it not? "Rome imitated Greece. And yet the Yankees are our relations, and they seem, or they try to seem, disgusted that their intellectual faces should show a family likeness! Did they expect that a slip from the British oak would produce something better than acorns the very first season? ... Let it be fairly admitted that they have made their literature in our image, as they could not but do; and force us not to apply chemical tests to their authors, to reveal the quantity of Gibbonism in their Prescott-of Tennysonianism in their Longfellow-the traces of the use of Cockney perfumes in the millinery wares of Willis." American literature, at any rate, is nothing to be ashamed of. "A breath of genius, as steady as a trade wind, breathes through all the books of Melville-the spirit of Hawthorne is as fresh, healthy, and rich as the beautiful plant (call us not sentimental!), 'with its locks of siller gray,' his namesake. And in Lowell, of whom we have now something to say specially, we recognise a fine-minded, high spirited, original man-of-letters, deserving to be better known here" (3 July 1852, p. 636).

These reviews were not lightly tossed off; Hannay's diaries 


\section{London: THe Successful Decade, 1850-1860}

clearly show how much work went into them, especially the longer ones. His Quarterly Review article on "English Political Satires," for example, involved nineteen days' research in the British Museum; the actual writing took sixteen days more. Nevertheless, despite all this labor and the abundance of allusions which these reviews contain, they hardly ever smell of the lamp: they are written with genuine verve, especially when they deal with subjects for which Hannay had a particular relish: the classics, heraldry, genealogy, the Navy, and Scotland.

The first of the periodicals to which Hannay contributed reviews, the Leader, did not, except on one occasion, call on Hannay's special knowledge of any of these fields. Between July 1852 and September 1855, he wrote ten reviews for Lewes' organ of advanced liberalism, generally concerning volumes of belles lettres and travel; there are also reviews of a History of Political Literature and a book of Christian apologetics whose author, Peter Bayne, had taken issue with a number of Carlyle's theories. Hannay did not attach much importance to this disagreement: rather, it was "almost amusing," since Bayne "is steeped in the Carlylian influence; he has learned to paint in the Carlylian studio; he cannot shake off the magical effect any way. But he protests, he argues, he declaims against the Carlylian doctrines! In all this we see a generous spirit compelled to reverence where it cannot agree" (16 June 1855, p. 583). Hannay's review of Cooper's The Two Admirals is an essay on "Naval Novels," in which he gives a succinct history of that sub-genre-one which, he holds, has significantly moulded the attitudes of young people in the Englishspeaking countries; The Two Admirals itself is referred to only in the last sentence, as "one of Cooper's best novels" (16 December 1854, p. 1195).

Often in his reviews Hannay made use of apt figures of speech to illustrate a point or add strength to an argument; this tendency was already marked in these Leader essays. Writing, for instance, on the first part of The Angel in the House, Hannay found that the romantic bliss which the poem celebrated was of a curiously constricted kind: the "author makes love like a parson-not a sleek, comfortable parson of the Paley school-but a romantic pietistic parson, much given to Coleridge, high church, and Gothic architecture" (4 November 1854, p. 1048). Hannay admired "the manly earnestness, 


\section{James Hannay}

the glowing vivacity, the hearty humanity, the glorious bits of vivid painting" in Westward Ho!, though he felt that there was a lack of subtlety in Kingsley's approach to his characters. "It is as if a painter in colour were to write 'Oh, you villain!' under his Jesuits or murderers; or to have a strip flowing from a hero's mouth, with 'Imitate me, my man!' on it. No doubt the villain is to be hated, and the hero loved; but we ought to see that sufficiently in the figures of them. We don't want a man with a wand, going about the gallery and haranguing us. Art is art, and tells its own story." Kingsley's didacticism was excessive ("the preacher overcomes the painter often") and his powers as a historical novelist were inferior to Thackeray's in Henry Esmond, "where the illusion of living in a past age is so delightfully kept up" (19 May 1855, pp. 474-75).

Of Thackeray's work, Hannay reviewed The Newcomes in the Leader after Bradbury and Evans brought out the complete novel in the summer of 1855; he said little here about Thackeray that he had not said earlier, particularly in the two Daily News notices of monthly parts of The Newcomes, but he had the whole book before him now and more space in which to develop his ideas. He still regarded Thackeray as the novelist of philosophic realism, primarily anxious to depict his society with scrupulous fidelity; naturally, in view of this, the novel lacked excitement in the all-too-ordinary sense. Hannay analyzed, with much penetration, the chief characters of The Newcomes, and pointed out that these people and their interactions, rather than plot, form the core of the novel.

Mr. Thackeray is a great artist, and knows that the story should grow out of the characters, and that to fit your characters to a story is to imitate the art of a street Punch. A little artificial fellow tumbles his puppets through a score of gambols, and thinks that we shall be so dizzy with the movement as to forget that they are made of wood. We are interested in what Hamlet does, because he is Hamlet. Our modern life carries on its loves, and hates, and schemes-its tragedies and its destinies -in drawing-rooms and back parlours, in "chambers," and in broughams. Do you expect from its doings the kind of excitement which you have in the stories of the Cid, of the Crusaders, of the Scots ballads, of Burger's Leonora? Be it distinctly understood that PLOT is not required by the philosophical novel. What is the plot of Don Quixote? (8 September 1855, p. 870)

To the Westminster Review Hannay contributed four reviewarticles: "The Poetry of the Anti-Jacobin" (October 1852); "Pedi- 
gree and Heraldry" (July 1853); "The Beard" (July 1854); and "Literature and Society" (April 1857).15 Though much longer and more lavishly documented than his Leader essays, they were not really very different in kind; in each case, a new book or group of related new books afforded a point of departure for a thorough historical and critical treatment of the topic it suggested. The review of a new edition of the Poetry of the Anti-Jacobin, for instance, turned into a disquisition on satire, British satire in particular, in which Hannay held that the best sort of satirist, far from being a dyspeptic misanthrope, is generally a good-natured man performing an exalted mission: "He plants himself on the common instincts of mankind, and when he exposes the solemn impostures of the world, he is appealing to the genuine, healthy sense of the people, and his laughter wakes them from the enchanted sleep they have been bewitched into" (LVIII [October 1852], 462).

In his piece on "The Beard" Hannay attacked a less formidable subject. Though as conscientiously done as any of his periodical work, the essay was something of a parody of the typically rather ponderous review in the contemporary quarterlies. John Chapman, the Westminster's publisher, had asked Hannay for 'a 'light article' (just as the milliners are preparing for summer and the season)subject-the Beard! The beard as affecting health \&cc. \&cc. would of course be a bore and out of my way:-but the beard under its literary aspect as a good subject for a literate jeu d'esprit in the reviewing line and one which my miscellaneous and desultory reading would tell in: for which, as well as the usual sound commercial, reasons I undertook the article." 16 On the pretext of reviewing three books with the engaging titles of The Human Hair Popularly and Physiologically Considered, The Philosophy of Beards, and The Beard: Why Do We Cut It Off?, and in response to the contemporary "agitation for the restoration of Beards and Moustachios to their historic position on the English countenance," Hannay gave in the article a history of the beard, tracing in detail the stages by which this adornment, once a symbol of venerability and masculinity, had become associated by the mid-nineteenth century with revolutionary and otherwise disreputable elements in society.

If Hannay permitted himself to indulge in some straight-faced facetiousness in "The Beard," in the essay on "Pedigree and Herald- 


\section{JAMES HANNAY}

ry" he approached with great good sense, obviously born of deep conviction, a subject which was often considered his "favourite insanity" (to use the phrase which Trollope applied a few years later to the genealogical Miss Thorne's hobby). To be sure, Hannay defended his passion for genealogy: "To trace lineage,-to love and record the names and actions of those without whom we could never have been, who moulded us and made us what we are, and whom the very greatest genius of us must know to have propagated influences into his being, which must, subtly but certainly, act upon his whole conduct in the world,-all this is implied in ancestry and the love of it, and is natural and good" (LX [July 1853], 89). Of this historic concern for pedigree the art and science of heraldry was merely a colorful symbol. Nevertheless, though "this sentiment of birth is profoundly fixed in the human mind" (90), Hannay conceded that no one in modern Europe would seriously argue that descent is the sole indication of virtue or ability. We must "just accept Gentilesse ... as the state of life through which Europe necessarily had to pass, and as that which formed the foundation of the existing state of civilization" (96). In spite of the extravagant statements uttered by enthusiasts (like Hannay) in their rasher moments, the only interest in the subject now

is its symbolic interest. And all that we could ever see, to have been discovered about the earliest practice of heraldry convinces us that its origin was natural and beautiful; that it was a kind of homage to the beautiful on the part of the leaders of Europe in days when life, though violent, was noble. It was the distinctive mark of these leaders, too, and a not ungrateful assertion of the fact of their leadership. Fossil-like as it has become now, who knows whether it may not yet once more acquire a symbolic value, if only as a kind of disgraceful signal that a man assumes to belong to the leading class without doing anything but put an odd figure on his spoons by way of showing it! Pedigree and Heraldry exist as a reproach to this last-mentioned gentleman; who forgets that the word "Gentleman" was, for long centuries, a faith of its kind throughout Europe. While this is forgotten, and perhaps naturally forgotten in our progress to other forms of life, it is as well, now and then, to look at these older forms sometimes, and try to get clear notions out of them. For gentleman has gradually come to mean a person of some kind of polish and assumption; though it is the man which is the base of the word, which is also the life of it: and which will have to begin again in 
its native vigour, after this peculiar feudal modification of it shall have outlived its utility (111).

Hannay's association with the Athenaeum, the extremely influential "Journal of English and Foreign Literature, Science, and the Fine Arts," began in 1854 and lasted until his departure from London in the summer of 1860 . During this time he contributed sixty reviews of some length, as well as an indeterminable number of shorter notices, to its respected and feared literary columns. Most of these reviews dealt with volumes of naval lore, voyages, Scottish history, heraldry, and genealogy; there were also critical examinations of new editions and translations of Cicero, Juvenal, Persius, Horace, Virgil, and Plutach. All of them, of course, evinced Hannay's experience, learning, and interest in these special fields.

A few of his other Athenaeum reviews are of particular interest. In this weekly as elsewhere Hannay maintained his role as enthusiastic advocate for the work of Thackeray. He hailed the republication in 1857 of the Miscellanies and the Irish Sketch-Book because these early writings now gave Thackeray's large and devoted public an opportunity to see the gradual, orderly way in which his genius had developed. The pre-Vanity Fair Thackeray had been steadily perfecting his skill as a satirist, a stylist, and a delineator of human character. "Here was one who talked in the style of the every-day world,-who could stir humour and passion without disturbing that equilibrium which the Englishman of our century loves to maintain; -a satirist who lashed the age without for a moment thinking of retiring to the desert;-a story-teller who interested deeply without ever moving the stationary leg of the compass which described the magic circle of interest round you-from some definite familiar point in the West-End of London" (3 October 1857, p. 1230).

When a trivial or a foolish volume came Hannay's way he did not hesitate to condemn it for what it was. Unfortunately for Martin Tupper, that popular versifier's books were twice given to Hannay to review in the Athenaeum. ${ }^{17}$ Tupper's Proverbial Philosophy had attained its eighteenth edition by the time Hannay wrote on it in 1854, a fact which did not heighten Hannay's admiration for the work.

Those who are the glory of our age-who keep alive our great traditions 
-are beaten in point of "editions" by scribblers who-had they flourished in Pope's time-would certainly not have escaped the "Dunciad." No man of judgment seriously speaks of Mr. Tupper except as a curiosity: -or affects to treat his Proverbial Philosophy as a thing belonging to literature. Here, indeed, is his only value:-his sale gives us a kind of guide to the taste of certain classes of readers. There is a dog in the "Wasps" of Aristophanes whose bark helps scholars to the pronunciation of a diphthong. Mr. Tupper may, in the same way, be of utility as an example of what can be received with relish by sections of the reading English. No one is misled into supposing that eighteen editions ought to settle the question of merit. The ear of Dionysius at Syracuse reverberates so loudly only because it is so long (30 December 1854, p. 1583).

In this review, as in a review of Tupper's Three Hundred Sonnets five and a half years later, Hannay allowed Tupper to condemn himself out of his own mouth by quoting freely some of the choicer bits of Tupper's verse, interjecting brief observations of his own, like "A good proverb says what everybody is trying to say, precisely as everybody would like to say it:-Mr. Tupper says what nobody needs to hear, in a manner which nobody would use but Mr. Tupper" (30 December 1854, p. 1584).

Another kind of book that Hannay lashed when it came under his scrutiny was the raptly admiring official biography, especially when such a work was written about a man still living. For some reason, lives of two New York editors, Horace Greeley of the Tribune and James Gordon Bennett of the Herald, appeared in England within a few months of each other in 1855, and Hannay dismissed them both with scorn as offensive to literary taste. They were not only incredibly pious in tone but unbearably tedious in the detailed treatment which the reverent biographers lavished on their subjects. The Life of Horace Greeley, he pointed out, was twenty times as long as Tacitus' Agricola, twice the size of the Twelve Caesars of Suetonius, and half as large as Johnson's Lives of the Poets. "Mr. Greeley has no reason to complain; but we cannot say as much for the reading public, which ought to have been consulted in the matter as well as Mr. Greeley" (17 March 1855, p. 316).

Hannay contributed essays and reviews to a number of other magazines in the 1850's-the Atlantic Monthly (he wrote the first essay in the first number, on Douglas Jerrold), the Civil Service 
Gazette, the Illustrated London News, the National Magazine, the New Quarterly Review, the Universal Review, and the Welcome Guest; of all his periodical connections, however, he was proudest of his relationship with the Quarterly Review, still at this time the most esteemed of the critical journals. ${ }^{18}$ Hannay had asked Thackeray in 1855 to introduce him to Whitwell Elwin, the Quarterly's editor, and Thackeray obliged, referring to his young friend in a letter to Elwin as "a worthy and clever fellow ... who loves reading and letters and is trying his best in the world-struggle"; "his critical writing," Thackeray wrote, is "full, easy, bellelettristisch and eminently readable." 19 This endorsement had the intended effect on Elwin, who was just then coming to know and admire Thackeray; he accepted an article of Hannay's on "Table Talk" (a revision and expansion of a rejected Household Words essay) for the December 1855 number and printed nine more of Hannay's longest and most substantial reviews in the next six years.

These essays, all but the last of which were collected in 1861 as Essays from the Quarterly Review, represent Hannay at the height of his critical powers. He was writing on subjects with which he was thoroughly familiar; his youthful exuberance (he was not yet out of his twenties when he began contributing to the Quarterly) was tempered but by no means stifled by his several years' experience as a reviewer and the knowledge that he was addressing the most discriminating and appreciative audience for sound writing then to be found in England. Titles like "British Family Histories," "English Political Satires," "The Historic Peerage," "Horace and His Translators," and "The Minstrelsy of Scotland" give an adequate idea of the contents of some typical Quarterly essays of his; far more than mere book reviews, they contain solid critical histories of their subjects, and admirably reflect Hannay's wit and learning. To take one example, "English Political Satires" is ostensibly a collective review of five books, the earliest of which is Thomas Wright's edition of The Political Songs of England from the Reign of John to That of Edward the Second, published in 1839, and the latest the 1856 volume of Punch. Instead of confining himself to the contents of these volumes, however, Hannay went back to examine the origin of political satire in classical antiquity, and then traced the genre's development in England from the Middle Ages to the mid-nine- 


\section{James Hannay}

teenth century. He discussed political satire in Tudor and Stuart England and under the Commonwealth, which was not covered in any of the books under review, as thoroughly and in as abundant detail as he treated eighteenth and nineteenth century satire, which was the subject of four of them. His essay on "Plutarch," the last he contributed to the Quarterly Review, not only deals with Clough's "correction" of the so-called Dryden translation of the Lives, but traces the history of Plutarch's reputation, sketches the life of the great biographer, and subjects the Lives themselves to a thorough critical analysis. All Hannay's Quarterly reviews display this sort of wide learning and the critical acumen of which we have seen so many examples in this chapter.

By the end of the decade, then, Hannay was firmly established as a critic and journalist of demonstrated ability, whose services were widely in demand. No longer did he draw exclusively on his own experiences and prejudices for material; no longer was he largely limited to satire as a technique. Though barely in his thirties, he was capable of dealing with literary and political issues in a mature, thoughtful, and informed way, and seemed to be on the road to even greater distinction.

Not all of Hannay's criticism and scholarship during the 1850's was doomed to speedy neglect by being set down in the relatively evanescent form of periodical work. Some of his most valuable writing on literature appeared between hard covers and, though he occasionally played the relatively modest role of editor, annotator, and preface-writer, almost everything he wrote was well worth heeding.

Hannay became an admirer of the poetry of Edgar Allan Poe rather early in his career. "I owe his acquaintance," he wrote, "to the society of a few young friends devoted to art and poetry" ( $P$, pp. xii-xiii)-very likely the P. R. B.'s. ${ }^{20} \mathrm{He}$ had taken the epigrams of several chapters in Singleton Fontenoy from the work of the American poet, who had died the year before the novel was published, and he referred to Poe in one place in that book as "one of the divinest poets of modern times" (II, 198 n.). It was not unnatural, therefore, that in the autumn of 1852 he turned his talents to editing a collection of Poe's verse, the first to appear in England.

The Poetical Works of Edgar Allan Poe, with a Notice of His 
Life and Genius by James Hannay, Esq. (1853) was a remarkable little volume, on several counts. It contained forty-three of Poe's best poems, judiciously footnoted and handsomely illustrated, and was received with sufficient acclaim to warrant three further editions within a decade. Of primary interest to use, however, is the introduction which Hannay contributed, a piece of criticism which neatly demonstrates Hannay's acumen and the sympathy he felt for his subject.

Though Poe had his champions in the early 1850's, his personal if not his literary reputation was low, owing largely to the lurid accounts of his life and habits given by some of the earlier writers on him. Hannay, to be sure, drew on the most notorious of these, R. W. Griswold, for some of his evidence, but this was more than compensated for by what he found in the writings of such friendlier chroniclers as N. P. Willis and Mrs. Frances Osgood and what he culled from the conversation of his young American artist-poet friend Thomas Buchanan Read. One wonders, too, if Hannay did not feel a certain kinship with his subject when he describes him as a young romantic adventurer with a strong literary bent, given to dissipation and perpetually in want of money. "I like to think of Poe in the Mediterranean, with his passionate love of the Beautiful,-in 'the years of April Blood,'-in a climate which has the perpetual luxury of a bath-he must have had all his perceptions of the lovely intensified wonderfully" (p. xv).

At any rate, Hannay clearly felt that he was introducing Poe's poetry to British readers, and, if this claim was somewhat exaggerated (since, on Hannay's own showing, Poe had attracted at least a select circle of admirers in England before his work was published there), this edition undoubtedly gave substantially wider circulation to his work in England and afforded the public across the Atlantic a sympathetic view of Poe on which later biographers and critics were able to build.

The critical insights which the essay contains are sharp and pertinent. (Not all of them apply to Poe: for instance, the then new Moby-Dick is praised as "such a fresh, daring book-wild, and yet true" [p. xii].) Poe's unceasing and largely successful quest, in Hannay's view, was for the Beautiful, and he was aided in this by his sense of form, his feeling for the music of words, and even by the 


\section{JAMES HANNAY}

calculating, analytical faculty which he brought to the writing of poetry. He had his limitations, to be sure: a lack of "spiritual emotion," for one thing, and a total absence of humor. "If," however, "his circle was narrow, it was a magic one" (p. $\mathrm{xxx}$ ). Without going "into recondite inquiries about the "Nature of the Poet," it was clear to Hannay that in Poe there was "a true poet, first of all." "I mean simply, that his view of a piece of scenery, or an event, or a condition of human suffering or joy, will tell itself to you from his lips in a music inseparable from it, and, by dint of perception into the heart of the feelings which such scenery, or event, or condition, would naturally awaken in every human soul" (p. xxvii).

During a Scottish tour in October 1852, while his edition of Poe was in the press, Hannay received an urgent summons from Thackeray.

If you have a little spare time on your hands, \& would undertake a small literary job for me, \& for Messis Smith \& Elder, of Cornhill, you would very much oblige me.

My Lectures are to be printed for fear of American Pirates; the text alone would make but a meagre volume, \& the book might be made much more entertaining by Notes, personal, illustrative, \& tant soit peu antiquarian to accompany the text. A few such notes I have got together, but had not time to complete them before going away. 30 or $40 £$., I believe, would be all that we could spare, but half as many days pleasant reading in the British Museum would enable you to do the work. It must be done directly; \& I should be very glad indeed if you can help me.

Please write to me at:-

The Lrd Ashburton

The Grange

Alresford

\section{Hants./}

\& say if you can come to London. I shall be back here on Tuesday, till Friday, the $29^{\text {th }} \&$ sail for America the next day: if you have no lodging, I can put you up, \& you will find Esmond against your arrival. ${ }^{21}$

The letter reached Hannay in Dumfries on the 22nd; he immediately wrote to Thackeray accepting the assignment, took the London coach the following day, and arrived at the Euston Hotel early on the morning of the 24th, after an all-night drive. Hannay was unable to establish contact with Thackeray until the 28th, when he "Breakfasted, and spent the morning with Thackeray, and received from 


\section{LONDON: The Successful Decade, 1850-1860}

him instructions regarding the 'Lectures,' and also, the MS. of them" (Diary, 28 October 1852), and he did not begin his "reading in the British Museum" until 8 November, but he kept at it vigorously for more than a month, steeping himself in material by and about the twelve authors whom Thackeray treats in the six lectures of The English Humourists of the Eighteenth Century.

However "pleasant" this research may have been, it was also arduous: Hannay's diary during these weeks repeatedly records his fatigue, ill-health, and nervousness. In four half-days at the Museum, for example, Hannay read widely in Scott's edition of Swift's works and consulted such standard biographical sources as Dr. Wilde, Lord Orrery, Delany, Dr. Johnson, Thomas Sheridan, and Scott, to all of whom he refers in his copious annotation of Thackeray's first lecture. These notes also include material on Swift from Temple's Miscellanea, Boswell's Tour to the Hebrides and Life of Johnson, and Voltaire's Lettres sur les Anglais, and genealogical information which not even Hannay, with his vast knowledge of the subject, could have trusted himself to set down without recourse to appropriate authority.

Hannay's work on the other eleven writers was no less painstaking. His contribution to the printed text of The English Humourists consisted chiefly in documenting and amplifying in footnotes points which Thackeray had made in the lectures proper. When, for instance, Thackeray says of Goldsmith that "with that sweet story of the 'Vicar of Wakefield,' he has found entry into every castle and every hamlet," Hannay quotes long passages in praise of the novel and its author from an English translation of Dichtung und Wahrheit and from Washington Irving (pp. 294-95, 295-96 n.). Or when Thackeray somewhat primly insists that "I can't pretend to quote scenes from the splendid Congreve's plays-which are undeniably bright, witty, and daring,-any more than I could ask you to hear the dialogue of a witty bargeman and a brilliant fishwoman exchanging compliments at Billingsgate," Hannay obligingly provides in his footnote to the sentence long quotations from Love for Love and The Double Dealer illustrative of "Congreve's daring manner" (pp. 7072; 70-74 n.).

There is nothing perfunctory about Hannay's annotations: on many pages of The English Humourists the amount of material in 


\section{James Hannay}

the footnotes equals or exceeds that in the body of the text. This taxing labor made greater demands on Hannay's scholarly than his critical endowments, but it unquestionably broadened his knowledge of eighteenth century literary history and may well have suggested the idea for his next major venture, a course of lectures on men of letters which, like Thackeray's English Humourists, eventually appeared in book form.

On 30 April 1853, a few weeks before the publication of the English Humourists volume, Hannay's six lectures on satirical literature were first announced in the press. He did little about them, beyond making preliminary plans, during May, and did not actually settle down to work over his material in earnest until 6 June, only a few days before the first lecture was to be delivered. This was literature with which Hannay was thoroughly familiar, and he did not seem to find the task of preparation especially demanding.

There were six lectures altogether, ranging in their subjects from Horace and Juvenal to mid-Victorian satire, and they were given in the four weeks between 15 June and 13 July 1853 at the Edwards Street Literary Institution, Portman Square, where Carlyle had delivered three series of lectures between 1838 and $1840 .{ }^{22}$ Hannay's lectures were well received, both by the large audiences "of more than the average intelligence" who attended them and by reviewers, ${ }^{23}$ and he repeated the last two at the Wesminster Literary Institution in December and the whole course at the Marylebone Literary Institution in January. Although Smith, Elder, whom Hannay approached with the manuscript of the lectures in the spring of 1854 , declined to print them, another publisher, David Bogue, accepted the book on the most favorable terms which Hannay had yet received for any of his work: he was paid a total of $£ 100$ for the first edition and the copyright. After Hannay had subjected the text of the lectures to some revisions, Satire and Satirists appeared in June 1854, and was highly praised by critics in the periodicals, by Carlyle, and by Hannay's Pre-Raphaelite friends, especially D. G. Rossetti and Ford Madox Brown. ${ }^{24}$

In general, Hannay's lectures treat his subject chronologically. Lecture I deals with Roman satire: particularly with its two greatest practitioners, Horace and Juvenal. Satire of the Renaissance and Reformation is the subject of Lecture II, especially the work of 
Erasmus and of two Scotsmen, Sir David Lindsay and George Buchanan. Although the third lecture begins with a glance at "early European satire," most of it is devoted to satire of the period "when the study of the classic literature became the predominant feature; and we shall find the most famous satirists reflecting the Horatian and Juvenalian influence, not only in spirit, but in form" (p. 115). This is, of course, the seventeenth century, and Hannay quite properly stresses Boileau, Butler, and Dryden. Lecture IV concerns three great eighteenth century satirists, Swift, Pope, and Churchill, and Lecture V treats "political satire and squibs" from the Civil War to Burns. In the last lecture, Hannay discusses the work of Byron, Moore, and lesser satirists of his own century. Hannay nowhere claims that his book is anything more pretentious than "a collection of passages in the history of Satirical Literature" (p. v); nevertheless, Satire and Satirists is an excellent informal historical introduction to his subject.

In its earliest fully developed manifestations, Hannay argues, satire flourished in ages when stable old orders were decaying or breaking up. Horace, born near the end of the Roman republic, witnessed and to some extent participated in the turbulence attendant on the establishment of the empire. He found plenty of material for satire in "the new corrupt luxurious life," which he was able to contrast with "the old classic life, which was waning out" (p. 27). Somewhat later, Juvenal's lifetime spanned the notorious reigns of Nero and Domitian-a period that lent itself even more readily to the purposes of the satirist. "It was a monstrous and unnatural period ... of gigantic opulence and titanic sin; a time both of blood and luxury; when the world ate and drank more, and lied and blasphemed more, and was at once more knowing and more superstitious than it has ever been known to be" (p. 32). Similarly, the age of the Reformation was disfigured by various sorts of abuses of ancient and once venerated institutions. "The religious man found that the machinery of his element was become disorganised; and the intellectual man, born with those qualities of humour and moral insight which combine to form the great satirist, found that the world was in a condition when they must be employed honestly in the delineation and correction of innumerable base, dangerous, and ridiculous objects around him" (pp. 55-56). At all periods, however, 


\section{James HANNAY}

and certainly from the last half of the seventeenth century to the first half of the nineteenth, satire has not lacked for targets, either in the established systems or the persons and opinions of the fanatics who have attempted to overthrow them.

It is Hannay's contention throughout these lectures that "the great Satirists have been good and lovable men" (p. vi), "great men, who would never have known scorn if they had not known love" ( $\mathrm{p}$. 5). Hannay ascribes these admirable qualities even to writers with whose lives history and tradition have dealt most unkindly. One of the very few questions on which Hannay disagreed publicly with Thackeray was the matter of Swift's character. In the first of his lectures on The English Humourists, Thackeray had treated Swift with unwonted harshness. Hannay conceded that Swift's moral visage displayed its share of warts, that "Mr. Thackeray's picture of Swift is human and lifelike; and no man who wishes to know Swift henceforth can dispense with it" (p. 155). But these blemishes must be explained, not merely "crowed over and exulted in," as "anti-Swift" critics have done (p. 154). After an examination of Swift's life and some of the charges that have been leveled against him, Hannay goes beyond even his other great mentor Carlyle, who had spoken of Swift in the same hall fifteen years earlier as "by far the greatest man of that time": 25 Swift, in Hannay's view, "is the greatest of the English satirists ... in all ways" (p. 174).

Byron is another maligned satirist to whose defense Hannay comes. He insists that "the good predominated in every way in the natural feelings of this man"; that his weaknesses and his vices were "temporary and conditional" rather than essential; that at the time of his martyr's death "he was developing into the high and pure man, of whom what he had written was the prediction"; and that his controversial works, like Don Juan, far from being dangerous and corrupting, are in truth "most beneficial and healthy" (pp. 250-52).

Hannay deplores the fact that, in his view, mid-nineteenth century England has produced no true satirists. Of course, the spirit of satire is far from dead, but it dissipates itself in the work of novelists, essayists, and journalists, who either have not absorbed it fully or have other concerns to occupy them. He holds that "in its peculiar and genuine form of the Satire Proper there is still plenty for it to do. And, as an agency, fighting is highly useful still in this world; indeed, 
it would be far healthier for all of us, to fight out our beliefs (if needful in the satiric form), rather than to veil malignity under the pretense of decorum, and gratify evil passions in vulgar and secret ways" (p. 270).

The vividness and sharpness of Hannay's approach in Satire and Satirists is in keeping with the origin of this material in popular lectures. Hannay gives a brief, lucid account of the life and times of each of his subjects, and draws freely on the works of each man to illustrate the peculiar qualities of his satire. In order to render his subject as clearly as possible, he frequently indulges in comparisons and contrasts, both between earlier satirists and between older satirists and their modern counterparts, who will presumably be more familiar to his audience. For instance, the antitheses and yet fundamental similarities between Horace and Juvenal run through all of Hannay's first lecture; near the end, he relates them to eighteenth and nineteenth century authors whom they resemble: "Take, as a basis, Swift's keenness and his ferocity; add a strong dash of Hogarth's humour; and tinge the whole with an infusion of the funereal poetry of Gray,-you have a notion of Juvenal. Now for Horace. Take sense like Franklin's, only with an air of higher breeding; mild and thin-flowing humour, like Addison's, minus the Christianity; abundant quantities of Chesterfieldian shrewdness and wit, with gaiety like Lady Wortley Montagu's; add a fair dose of Campbell's poetic spirit, and Washington Irving's poetic taste,-and you perhaps have something that gives you a glimpse of Horace" (pp. 40-41).

A fanciful and generally effective streak of imagery runs through all these lectures, endowing Hannay's subject with more liveliness than it might display in other hands. His description of the nature and function of satire is especially vivid: "How many natural agencies does this multiform power resemble! The flashing lightning, terrifying the evil-doer, while purifying the air-such is Satire, when great and earnest. The white nettle-flower,-the sharp, prickly, torturing broom, all blazing with colour-these typify light and brilliant Satire. War-rockets, too, furnish a tolerable object of comparison; while many an epigrammatist, lively but harmless, scintillates only too often in sparks as evanescent as those struck out on the highways by the hoofs of an animal which has long supplied a favourite 
illustration to the satirical writer" (p. 4). Later in the lectures, to cite another example, Hannay makes use of the well-known fact that Pope was virtually a dwarf to explain, by analogy, his view of Pope's character and the effect of his work: "His whole nature was small, thin, and fine, rather than large and broad. Like a tongue of flame, however, thin and small as it was, it was high-aspiring. Its tendency was upward. He loved sublime objects; had a feeling for the sublime and high, and specially for the elegant, rather than for the sacred or the beautiful. This, as it was his artistic condition, so it was his moral one" (p. 175).

Although Satire and Satirists purports to be, and is, a piece of objective literary history, a number of Hannay's characteristic interests and preoccupations appear in it quite clearly. There is, first of all, his obvious affection for his subject. Satire was one of his favorite literary forms and Horace his favorite classical author. Also, though he does not exactly follow Carlyle in calling Burns a Hero, his Carlylean notions of Hero-Worship are evident in his remark that Burns, despite his notorious rebelliousness, was "born loyal": "the first, the indispensable condition of loyalty is, that you must have something to be loyal to! You can't be loyal to village despots and 'Holy Willie:' that is not loyalty; that is flunkeyism, the basest attitude that the human soul can assume" (pp. 233-34). And, finally, in his pen-portrait of the dissipated Charles Churchill, there is discernible the same sense of kinship and perhaps self-exculpation that one might notice in his treatment of Poe:

He adopted, in those years of triumph and excitement, that kind of moral opinion which has been exemplified in Fielding's Tom Jones, by Charles Surface, and partially by Robert Burns,-the doctrine, namely, that if you are a good-hearted fellow and hate humbug, you may set the respectable moralities at defiance. This school, which has had, in every age lately, some brilliant disciples, is rebellious and radical in opinion, high-flown in liberality and the generous qualities, and-does not go home till morning. Its 'porch' is the tavern porch, and its 'garden' is Vauxhall: and though it has a basis of truth as against an opposite school, it is a very unsatisfactory and unprofitable school, and is only tolerable as a stage towards higher theories of life (pp. 191-92).

Hannay, we may observe here, returned to the subject of satire twice in the half-dozen years following the publication of Satire 
and Satirists. "English Political Satires," a major review article in the Quarterly, to which I referred on pages 93-94, appeared in 1857; his essay on "Hogarth as a Satirist," written three years later, was published as the introduction to a collection of The Complete Works of William Hogarth in 1861. This spirited and persuasive essay echoes everything Hannay had said about the character and function of the satirist in his book, and clearly relates Hogarth's satiric work to what his friends and contemporaries, particularly Swift, were doing in literature. The influence of a social satirist like Hogarth, Hannay pointed out, though difficult to trace with precision, must have been immense:

Wherever there has been improvement, it has been improvement of a kind which he was labouring in his time to bring about. "Gin Lane" is a less horrible thoroughfare, and more under the control of the laws in these days of gas and police. We have acts of Parliament levelled against the abominable young rascal who is torturing the cat in "Progress of Cruelty-Part I." Bedlam is a paradise for the Rake compared with what it was when Hogarth sent him there. Apoplectic gentlemen, requiring bleeding at a public dinner, and dying with oysters on their forks, are unknown. Counsellor Silvertongue would be cut on circuit. All the amenities of life-in short, the decencies, decorums, humanities, and philanthropies generally-are infinitely advanced since the days of William Hogarth. With the other side of the question we are not now concerned; but so much is true; and the great satirical painter must surely be allowed his share in the change. What reformer or legislator of the period which has wrought the change has been ignorant of his works? What student of the past, or what thinker has not learned something from them? Their familiar figures, reproduced in many shapes, have fallen broadcast over the land; and while educating thousands by their thoughtfulness, charming them with their humour, and touching them with their pathos, have helped to prepare the mind and heart of England for a milder and purer social life (p. xiv).

Hannay's next large venture into literary history after Satire and Satirists was addressed to a very different sort of audience, and accordingly emerged in a very different form. In the spring of 1858 , Henry Vizetelly launched a penny weekly called the Welcome Guest, in which the work of a number of contributors to the Illustrated Times appeared. Vizetelly's aim was obvious: to take advantage of the popularity of Household Words by directing his new magazine 
to the same vast public to which Dickens' periodical appealed and by casting it in a form very similar to that of its famous predecessor. ${ }^{26}$ The preface to the first volume of the Welcome Guest seems to challenge Dickens' aim of reaching with his magazine as large a body of readers as possible in order to instruct as well as to entertain them: there would be no attempt "to curry favour with maudlin philanthropy, or demure canters on the intellectual superiority of the masses and the holiness of univeral fraternity" in the Welcome Guest, no "coalition with any professional trumpeters of literature for the million, or impertinent would-be improvers of the 'mental condition of the lower classes." "Though any intention of writing down to the masses was thus disclaimed, much of the writing in the new magazine, in common with the large and growing self-help literature of that day, was clearly of an "improving" nature.

Among this was a series of fifteen essays concerning the history of English literature on which Hannay began working in November 1858. A Course of English Literature was first published in the Welcome Guest between 9 April and 23 July 1859; seven years later Hannay assembled the articles and reprinted them, with only minor changes, as a book. The purpose and the tone of this Course are explained by a footnote to the first essay, as it appeared in the Welcome Guest: "From the time when the 'Welcome Guest' first made its appearance up to the present moment, the Editor has been continually appealed to by some of the more studious amongst his readers for advice as to the class of books they ought to peruse, in order to obtain a general acquaintance with the chief productions of English literature. With the view of assisting this particular section of readers of the 'Welcome Guest,' and, it is hoped, of contributing to the general interest of the publication, the present series of articles has been prepared" (II [9 April 1859], 213 n.). ${ }^{27}$ Throughout, Hannay addresses himself to the reader whose formal education has been more limited than his intelligence or his ambition to add to his store of learning. Hannay's chief concern is less to give a history of his subject than to suggest to his reader how to go about mastering it: the essays form a kind of syllabus, or, as one reviewer of the book suggested, it was "not so much a Course of English Literature as the Incitement to a Course of it."'28

The work, accordingly, is full of practical hints to young men 


\section{LONDON: THE SUCCESSFul DecADE, 1850-1860}

bent on improving themselves-hints which Hannay, who was himself largely self-taught, was singularly qualified to give. His advice on the benefits of regular, systematic reading sounds like the fruit of his own strict regime of study:

Reading is like any other part of the system of life; it will run in the groove to which you accustom it. Once get in the way of reading in a special train, and with a special object, and the mind accustoms itself accordingly. Hence the advantage also of managing to associate particular hours with particular kinds of reading. If you have only two hours a day, be sure to assign each hour its special subject, and it will come as natural to you (there is nothing like a homely illustration) as your dinner. The order of the most regular man will be sometimes broken: a headache, a casual visitor, or what not, may destroy one evening; but still the formed habit will tell on the whole twelvemonth (p. 95).

When he suggests how individual works ought to be approached, his recommendations are no less sound and specific, and probably more defensible by modern critical standards. There is, for example, a rather surprising insistence on the importance of form in his prescription for the proper reading of a play by Shakespeare: "Take a play of Shakespeare's by itself, and study it as a whole. See how the construction is suited to the nature of the characters, and how the characters seem at the same time to compel just such an order as that of the construction. Study, also, each character by itself, as well as in juxta-position with its likeness or its opposite; and observe the complications and (apparent) contradictions in each" (p. 191).

Another piece of advice, to which Hannay returns again and again, in large measure determines the organization of his Course: he urges his audience always to regard the writer and the work to be studied in their historical setting. History, indeed, he says, is "the back-bone of the whole course" (p. 9). In keeping with this idea, Hannay devotes his first four essays to history and historians. Not until Chapter V does he begin treating literature per se, but for the next three chapters he subordinates books and authors to the flow of history, which he divides into seven periods, from the time of the Saxons to the year of the first Reform Bill. In his discussion of each of these "Epochs," he begins by treating the most significant historical circumstances and then goes on to deal with the literature of the period and the men who wrote it. 
Although this method is rather rigid and no longer very fashionable, it is certainly defensible. What is less defensible, and clearly inconsistent with Hannay's announced intention to "treat simultaneously of different branches of English literature, but always with an eye to their grouping in epochs" (pp. 8-9), is his abandoning this pattern of organization after three hasty chapters, and spending the next seven on separate chronological treatments of the major "different branches": biography, poetic drama, poetry (two chapters), fiction "and Light Literature Generally," and philosophy (two chapters). This is not only inconsistent, but it involves much duplication: many authors are considered twice, once in the historical overview and once in the chapters on the literary genres. There is a final chapter on "Contemporary Writers."

$A$ Course of English Literature is short: there is room for very little discussion of particular works, and Hannay's remarks on individual authors and on literature in the abstract tend to be general and traditional. The book nevertheless is "full of sense and stimulus," as Saintsbury was to remark at the end of the century, ${ }^{29}$ and must have achieved its instructional purpose quite satisfactorily. The didactic tone of much of it may occasionally grate on the modern reader: in enumerating some important histories of philosophy, for example, Hannay asserts that "all these works should, as a matter of course, be found in all 'Institutes,' 'Athenaeums,' 'Institutions,' or what not, pretending to be places of literature throughout the kingdom. There is no excuse for their absence, and the supply of novels should be cut off, if need be, till they are procured" (p. 262). Such a dictum is worth quoting, if only to help correct the view of Hannay as a Bohemian ne'er-do-well to which some of his contemporaries gave currency, but this sort of stuffiness is more than compensated for by many lively passages, like Hannay's impatient dismissal of that "long-winded, refining sentimentalist," Richardson: "The son of a trader, and a trader himself, he had an exaggerated horror of everything belonging to common life; and meanly sneered at Fielding, who-sprung from princes and warriors-heartily relished even the humblest forms of human existence. Those may try his 'Pamela' or 'Clarissa' who have read everything else recommended in our volume" (p. 24l).

In Hannay's treatment of contemporaneous literature, his old 
loyalties and prejudices remain unshaken. Thus, Carlyle is the superior of Macaulay ("People don't buy stinking fish, for the sake of their shining" [p. 315]); Thackeray, with all his great virtues, is more estimable than Dickens, who is a victim of his middle class origins and his predominantly middle class audience: "his faults, such as they are, are the faults belonging to a too zealous and narrow worship of modern social ideas, and a too great neglect of established, classical, and ancient literature" (p. 321).

Quite properly in such a work, Hannay avoids ambitious theorizing. For instance, he does not concern himself with the nature or the proper definition of poetry; instead, he reminds his reader, the business of "our student ... is to seek in the best poetry that stimulating and elevating excitement, with its accompanying mental discipline, which poetry naturally produces;-our business is to tell him where such is to be found, and how it is best to be enjoyed and appreciated. All the practical good of the study and all the solid pleasure of it may be obtained without sounding the abysses of speculation..." (p. 176). That student, we may suppose, got from $A$ Course of English Literature exactly what he hoped for.

The modern critic, living in a great age of literary historiography, may smile at Hannay's presumption in taking on this task and shake his head at his lack of method in carrying it out, but it is impossible not to be impressed by Hannay's liveliness and good sense. And a number of his ideas, while not exactly startling, do still today furnish food for thought. There is, to cite but one more example, Hannay's hypothesis about the cause of the peculiar development which English verse drama has undergone: "The fact that Shakspeare fell upon Elizabeth's reign, and that the theatre was then flourishing, has had a peculiar effect on our literature. While Shakspeare himself is so great that he leaves his contemporaries behind him, and makes the general admirer of his plays altogether indifferent to the fact that they were first played at such and such a time; that same greatness has also kept the form and colour of his time permanently stamped on our dramatic literature.... A successful new tragic or semi-tragic play is always quasi-Elizabethan" (pp. 182-83). And the modern reader interested in the history of ideas is bound to feel a certain curious satisfaction when he sees a writer like Hannay, obviously bent on popularization, taking an evolutionary 


\section{James HaNnay}

view of literary history in the year of The Origin of Species: "We need scarcely say, not only that all the branches of our literature are related to each other, but that they all evolve themselves out of a previous stage of life, precisely like any other natural production" (p. 9).

Though Hannay wrote busily and effectively about literature throughout the 1850 's, the flow of original fiction from his pen, a gushing stream in the years of Biscuits and Grog, A Claret-Cup, Hearts Are Trumps, King Dobbs, and Singleton Fontenoy, dried up into a trickle after 1850. In the five years before the publication of Eustace Conyers in 1855, Hannay's production of imaginative literature was confined to rather thin naval sketches and stories printed in the United Service Magazine and elsewhere; the two collections of fiction by him which appeared between Fontenoy and Conyers consisted of previously published work. In the first, Sketches in UltraMarine (1853), Hannay assembled Biscuits and Grog and A ClaretCup (now retitled "Personal Reminiscences and Sketches of Percival Plug, R. N.; First Series" and "Second Series," respectively), a severely abridged version of King Dobbs, and two series of pieces from the United Service Magazine, "Mr. Snigsby's Yacht" and "Pipp's Cruise in the Violet." Except for the cuts in King Dobbs, the only changes Hannay made in this material were editorial, though he did tone down a few of the more intemperate passages in his earliest work. For example, a suggestion of gross immorality among high naval officers reads as follows in A Claret-Cup: "The Admiralty are not altogether unforgiving, at least, if we may judge from the fact that men now figure (and that pretty high) in the service, who have been at one period dismissed from it, for offenses to which, as we intend our book for respectable circles, we shall make not the most distant allusion" (pp. 101-02). The passage appears in the Sketches in this abbreviated and much milder form: "The Admiralty are not altogether unforgiving to sinners of rank!" (p. 166) The second such collection, Sand and Shells (1854), contained fiction which had appeared in the United Service Magazine during the previous two years: "The Family Ship," "The Court Martial," "Mr. Adair's Narrative," "Fitz-Gubin; or 'Swell' Life at Sea," and "Jack's Christmas Ashore." 
Eustace Conyers, however, was a full-scale work of original fiction-if "original" is the proper word to apply to a novel as full as this one of devices which the author has used time and again in his earlier writing. The protagonist of the novel is the by-now familiar young scion of an old and honorable family whose fortunes have sunk from their former feudal height in the materialistic, commercial nineteenth century. It is symbolic of the disease of the age that the ancient seat of the Conyers family is now in the grasping hands of a nouveau riche capitalist. "By a job of the Admiralty's, [the present owner's father] got wind of the fact that they were going to copper the navy; he bought all the copper in the market, and cleared an immense sum" (I, 130). The contrast between Hillslopes, the modern country house belonging to a member of "the pecuniary baronial order," and the old manor house, falling into decay on another part of the estate of Conyers-lea, reflects Hannay's profound dissatisfaction with modern society:

As the ancient houses of England and Scotland reflect the epochs when they were built, and symbolise the life of their early possessors, so do these too, in their generation. They need not turrets, for have we not a police? nor immense halls, for have not modes of life changed, and do we not, when we feast our retainers, pay the bill for their dinners at the Jowler Arms, and wash our hands of all trouble thereby? They are comfortable, spacious, splendid, convenient, far superior, no doubt, in the sanitary point of view, to the habitations of past times. Everything about them, park, gardens, lawns, trees, wears a sleek, yellow smirk, as of gold. . . . No dryad dare haunt the grounds, or she would be arrested for trespassing.

The advantage of a place like this is, that it suits one man as well as another; for it does not represent a man, but an income. If one proprietor dies of apoplexy from over eating, or is stoned to death by a mob, a martyr in the cause of a poor-law, no great harm is done; for another wealthy man fills the commodious mansion suited to a family of the first rank equally well. The population of the neighborhood look to the hall, not to the lord of it. The hall represents so much custom to tradesmen, so much employment, so much charity, so much soup, coal and blankets, or so many tracts, if that is a fancy of the proprietor; but the people scarcely mind who the agent is, on whom such an extent of property imposes these services. . . . Here it is, always spacious, convenient, \&c.; and unromantic, and little beautiful, as it is, it exactly symbolizes the money power, which, and nothing else, it represents (I, 156-58). 


\section{JAMES HANNAY}

The Carlylean tone of this sort of social criticism, which runs throughout the novel, is reinforced by many admiring references to Carlyle, his work, and his ideas. And when Eustace gives his friend Don Emanuel in Brazil an ironical account of English life and institutions, the spirit of Carlyle is unmistakably and prominently heard in everything he says:

"We have reformed our constitution; so that it is our boast that the meanest individual may rise to be Prime Minister; a fact, indeed which comes about sometimes!...

"Should anything go wrong, our remedy is at hand; more electors who are sure to be wiser than the existing body; more middle-class potentates, because already the Leathers and Bobinses are far beyond the pre-reform men, in parts. Indeed, I for one, see no bounds to our gradual development. Take the mere pulling down the aristocratic and territorial interest, and see what glorious results we shall have! No tie between the proprietor, the tenant, and the labourer, except the perfectly satisfactory one of the average rate of wages. A gradual disappearance of superstitious traditions and stupid sentiment. Everything open to everybody who has money, and money gradually amalgamating with the newer aristocracy: and when it stumbles on accidents and errors, justly throwing the blame on the old noble families, who did, indeed, turn out mediocrities like Bolingbroke and Chesterfield, Mansfield and Erskine, and Byron, but who are effete. But here is our greatest and noblest feature. Our progress is all in the purest spirit, and when our reformers change anything, it is from motives as holy as the inspirations of the early Christians. They have none of the weaknesses of the men whom they assail, and no sordidness, no envy, no love of power. The manufacturers who had [sic: head?] the movement, are beloved by those whom they employ,-their factory towns are models of happy comfort, and their operatives shower roses on their path as they go by; a handsome race of men, full of high sentiment and elegant culture" (II, 227-30).

While the Hilderstones reign ostentatiously over Conyers-lea, the Conyers family itself lives in the modest vicarage of Swillington, where the Reverend James Freville Conyers looks after his spiritual, his scholarly, and especially his genealogical and antiquarian interests. Like Hannay's previous protagonists, Conyers' son Eustace joins the Navy to find adventure and learn about Life. He is endowed with a "sound, good brain, and a sound, good heart; with a nature passionately demanding active employment, and finding the sea 
afford it, somehow, by instinct-a dash of humour, and a love of ita leaning to old family traditions, and a sturdy 'prejudice' or two, relieved by common sense, and every day experience" (III, 274-75). In his manly, clear-eyed straightforwardness and idealism he is contrasted with the shifty opportunist Mildew, who remains ashore to make his fortune (just as Fontenoy had been contrasted with Lepel); afloat, he finds a Carlylean counselor in Walter Lindsay (just as Fontenoy had depended on Welwyn for guidance). And, like Hannay's other ardent young heroes, Eustace Conyers discovers in shipboard life a miniature world in which brave, dedicated, able, high-spirited men contend successfully with scoundrels, misanthropes, incompetents, and fools. Though a ship is this sort of microcosm, there is also the suggestion that it is somehow better than the great world, that the sea is a refuge from the evils that beset the landsman. When Eustace's ship, the Lotus, encounters tropical fever on the coast of Africa, she puts "farther out to sea; the grand old sea being in all ways your true friend, saving you from ill-health, relieving you from ennui-and even keeping your duns off you ..." (III, 39). Later, when Eustace is temporarily disappointed in love he tells his sister that " 'I must go to sea!' . . In all trouble and perplexity, this was Eustace's great idea of consolation" (III, 107-08).

Like the two long works of fiction which preceded it, Eustace Conyers contains more strands than Hannay is able to weave into a satisfying whole. In addition to the naval plot, which eventually propels Eustace, quite unjustifiably, to a brief sojourn on a Brazilian jungle plantation (just as King Dobbs and his friends had been transported to Somniata), there is the usurpation theme (will the Conyers family ever have its ancient lands restored to it?); a mystery, never fully developed or explained, surrounds the Lotus' clerk Poot, who turns out to have an interest in the slave trade which his ship is supposed to be helping to suppress, and who has some sort of sinister connection with Eustace's native county of Huntingland; and, of course, there is a good deal of theorizing about politics and genealogy, "blood and culture," which frequently slows down or interrupts the narrative, despite Hannay's insistence that Eustace Conyers "is a novel, and not a pamphlet, or treatise" (III, 26). Some of the philosophical conversations in which Hannay's characters engage have a Peacockian sparkle about them; more often, they 


\section{James Hannay}

verge on windy pretentiousness. It must be said, however, for the sake of accuracy and in fairness to Hannay, that he does not always take the lofty notions propounded in the novel too seriously. Some good-natured fun is poked at the Reverend Mr. Conyers' mania for pedigree, and when Eustace, at one point, declares loftily that "I have blood-race; I connect myself with the heroic ages of Europe. I spring like a ray of light from the stars of the middle ages!" (III, 101), Hannay immediately dismisses that as "passionate rant""such alone can it appear to a well-regulated mind" (III,102).

There is, of course, a love plot, the issue of which is never for a moment in doubt: Eustace woos and finally wins the beautiful Elizabeth Hilderstone, though the sudden death of her father, who opposes the match, is necessary before they can marry. Again indulging in his weakness for the improbable coincidence, Hannay has Hilderstone die as a result of the shock he receives when Poot, turning up out of nowhere, informs him that his long-lost son is not dead, as he had presumed, but alive and well and prosperous: that this son is, in fact, no other than Eustace's Brazilian friend Don Emanuel, who inherits his father's estate at his death. As Lindsay's cousin says to Eustace, "you ought to have Conyers-lea, yet it would be a little too like the end of a fairy tale, if you got a lovely girl, and your first love, and your family estate back, all at once" (III, 293-94). Though Hannay stops short of this "fairy tale" conclusion, there is every indication that the childless widower Don Emanuel will leave no heir and that the Conyers family, in the person of Eustace's son by Don Emanuel's sister, will soon again possess its ancestral properties.

Eustace Conyers, in short, displays all the virtues and all the defects of its predecessors: lively writing about naval life and manners and sharp satire of a Carlylean sort; an excess of theorizing and a cumbersome, ill-constructed, and improbable plot. The novel was very well received: the Athenaeum, for example, called it "fresh, genuine, healthy" (26 May 1855, p. 613); the Literary Gazette referred to it as "a capital naval story, with stirring adventures, and well drawn characters" (30 June 1855, p. 404); and the Critic regarded Eustace Conyers as "certainly the cleverest novel the season has produced, and Mr. Hannay's best and most matured work" (15 June 1855 , p. 281): The 1856 edition of a standard mid-Victorian 
reference work, The Men of the Time, praised Eustace Conyers highly in its entry on Hannay: it "is," one reads, "generally regarded as one of the cleverest and most charming works of fiction that has appeared in recent years, and exhibits a singular power in the delineation of character, a fine sympathy with ages of chivalry and romance, a knowledge of heraldry and genealogy, rare, indeed, in our degenerate days, and views of political affairs that could only have been conceived by a man of genius and an original thinker" (p. 356). The novel was translated into German in 1856, and brought out in a cheap edition by Chapman and Hall the following year.

In spite of all this acclaim, Hannay produced no more fiction in the eighteen years of life that remained to him, and the reason for this is not hard to discover. Hannay had one novel in him, and he wrote this several times over. After Eustace Conyers, even he must have realized that there was nothing more to be got out of the story of the young midshipman who discovers the world and his own identity in the course of his naval service; that there were other branches of literature which would give him greater freedom than prose fiction could to express his philosophical convictions and exercise his critical intelligence.

The same decade during which Hannay became established as a man of letters of some renown also marked his transformation from a young Bohemian to a respectable family man.

In the early years, he continued to move about frequently, exchanging one set of London bachelor lodgings for another seven times between 1850 and 1852. For a few months in 1850-51 he again stayed with his father at Ridge (very likely when his funds had run particularly low), and while in Hertfordshire he became involved in an affair with one Georgiana Lock, who bore him a son on 7 December 1851. "Don't think me blind to the proper view of the matter," he wrote William Allingham (who was then living at Ballyshannon, in Ireland) three months before the child's birth. "I am sorry for my absurd conduct and I do what is my duty to do regarding the temporal consequences of the affair. For the spiritual do.-the Sin wandereth against me in the Infinite, and we shall one day meet face to face." 30 Though he says little about the matter in the diaries, 


\section{James Hannay}

which do not begin until the following year, it seems clear that Hannay behaved as honorably as possible under the circumstances; he regularly saw his "natural son," who was called James Maxwell Lock and nicknamed Jimbo, until his own departure from London in $\mathbf{1 8 6 0 .}$.

It is in Hannay's letters to Allingham, too, that one finds the earliest references to his courtship of Margaret Thompson, the young lady who was to become his first wife. In the autumn of 1851 (the exact date of the letter cannot be determined), he mentions taking a new volume of Allingham's poems to the house of the artist Kenny Meadows.

Have you not heard me speak of a niece of his, Margaret? She was there-a sweet grave girl-

\section{"Love walks the pleasant mazes of her hair"}

as Cowley says.-But not to bore you with all $I$ think of her (shall we have the Honeymoon at Ballyshannon?)-let me narrate that I did assemble the girls in the absurd little garden arbour-did take your volume in hand there-did effectively read from it-and luminously dissert on it-to your honour and mine own! ${ }^{31}$

Obviously, lack of money made a long courtship necessary. "You speak of wishing for Somebody to Love," Hannay wrote Allingham on 2 October 1851 ,

(bless me-

surgit amare aliquid,

as Lucretius says. What an odd chance that the same word means bitterness and to be loved?)-but what can I do? I could not even raise the wind to blow Hymen's torch! ... Better be with one's heart free than have a love you cannot gratify. ${ }^{32}$

The marriage did not take place until 24 February 1853, at the Scotch Church, River Terrace, Islington, and on 7 March the couple moved into the house which was to be their home for the next seven and a half years, 10 Pleasant Row, Canonbury (Islington).

According to all available accounts, Margaret Thompson Hannay was endowed with "uncommon beauty and goodness". (as John Cordy Jeaffreson put it). "A sweeter or more conscientious woman ... never ruled a fond husband." 33 She was Dante Gabriel Rossetti's model for Beatrice in the water color "Dante's Dream," ${ }_{34}$ and 


\section{LONDON: THE SUCGESSFUl DeCADE, 1850-1860}

William Rossetti remembered her as "a beautiful and most estimable lady." ${ }^{35}$ As far as one can judge from her few surviving letters, Margaret was indeed a lively and attractive woman, a loyal wife, and an affectionate mother.

Pleasant Row is gone now, but Jeaffreson described No. 10 as "a small house that overlooked the New River. Unless my memory is at fault, the little house stood within a stone's throw of the Lower Road [now Essex Road], and was one of a lot of similar houses, that bore the pleasant name of Pleasant Row." 36 There was a garden, and within easy reach lay the open country of Highbury, Highgate, and Hampstead, in which Hannay and Margaret enjoyed taking long walks.

During the years at Pleasant Row, Margaret gave birth to five children: David, named for Hannay's father (born on Christmas Day, 1853); Elizabeth (1 March 1855); Margaret (14 September 1856); Patrick (6 October 1859); and another boy, born in February 1858 while Hannay was on a lecture tour in Scotland, who lived only a few days and was buried before Hannay could return to London.

Hannay's routine through most of this period was a busy one. Mornings and evenings he generally wrote and read at home, devoting a good deal of time to studying the Latin classics and teaching himself Greek. He spent several hours of most afternoons in the Reading Room of the British Museum, thirty minutes' walk from Islington, working up subjects on which he was writing or merely reading in areas that interested him.

It would be a mistake, however, to suppose that Hannay turned into a bookish recluse after marriage. His gift of friendship and his fondness for conviviality continued undiminished, and there were still the spirited (and often spirituous) evenings at the clubs, the debating societies, and the rooms of friends, many of whom visited him also in Pleasant Row. He continued to associate with D. G. Rossetti and his circle, though he saw less of them as the decade wore on and he became more involved in regular journalistic commitments, particularly to the Illustrated Times.

A number of his colleagues on that paper were also very close to him personally, especially the two sub-editors, Frederick Greenwood and John George Edgar, whom Espinasse called "the literary Bohemian most loved by Hannay, the Jonathan of this 


\section{JAMES HANNAY}

David." 37 Hannay was strongly drawn to this eccentric young man, an author of boys' books and political articles, whose views on the importance of "blood" in the sound government of the nation were remarkably similar to Hannay's; like Hannay, too, Edgar was a Scotsman, a native of Berwickshire. Other literary men and journalists who are frequently (and most often laconically) mentioned in Hannay's diaries as visitors and boon companions include William Allingham, Coventry Patmore, Joseph Archer Crowe, the Broughs, the Blanchards, G. W. Thornbury, William Stigant (or Stigand), Wiltshire Stanton Austin, Edward Wilberforce, and T. E. Kebbel. Throughout the 1850's too, he still met Carlyle and Thackeray with some regularity, though he was never really among their intimates.

Even though his professional and family obligations, and his ambitious programs of study and reading, made ever greater claims on his time, there were still evenings when, as he wrote in his diary periodically, he stayed "out too late." Jeaffreson describes Hannay's behavior on one of these occasions, at a Kensington dinner party, when he attempted to ingratiate himself with a man named Bruce by insisting "that he must be related to the Scottish royal family of the same name... much to the embarrassment of Bruce, who kept denying it, and who was very sensitive about the fact that his father had been a tailor." After the party, the

other guests had all departed, and were in bed at their respective homes, when Hannay and I went forth from No. 4, Pembroke Terrace, and began to walk towards London in the small hours of the morning. As there were no empty cabs on the way till we neared Piccadilly Circus, it was fortunate for us that it did not rain. Though cold, the night was fine, and Hannay was a delightful companion as we moved along the main road. Twice or thrice he stopped in the brisk walk to give money and wholesome counsel to indigent pedestrians, whom he exhorted to withdraw their confidence from plebeian demagogues, and to compass an improvement in their worldly fortunes by consulting the wishes and winning the favour of the ancient gentry of "these realms." At a coffee and bakedpotato stall he entertained so large a company of destitute wretches, that I insisted on contributing to the charges of the meal; and, whilst his guests were consuming their food and drink, he talked to them in a kindly way that pleased them not a little. ... On coming to a quarter where night-cabs abounded, we found ourselves so refreshed by exercise in the frosty air that we decided to walk onwards for another mile. Life 
is worth living to young men, who can enjoy a march from Holland Park to Holborn Hill in the middle of a cold night. ${ }^{38}$

On 1 January 1857 , to cite one of several examples, Hannay recorded in his diary that he "spent New Year's Day at home,-not altogether free of reminiscences of Lennox Hannay's champagne and sherry." (He and Margaret had visited his cousin in Bayswater on New Year's Eve.) There are not many entries like this, and it would be rash to mistake even immoderate social drinking for anything worse, particularly in view of the fact that these were such extremely busy and productive years for Hannay. No really dissipated man could have achieved all that he achieved. Nevertheless, there are danger signals of trouble ahead even during the 1850's, and one wonders exactly what Hannay was thinking on 1 January 1856 when he added to a rather conventional list of New Year's resolutions ("hard reading," "attention to work," "increase of seriousness") one that called for a "moderate use of banquets."

Occasional long periods away from London served to vary Hannay's routine. Several times in the 1850's the family left the city for summer holidays lasting from a few weeks to a few months: at Ridge in 1854 and at the seaside resorts of Southend and Worthing in 1856, 1857, and 1860. Getting back to the ocean, even as a landsman on holiday, proved exhilarating to Hannay, who found great enjoyment in sailing and salt-water bathing. During his first stay at Southend, he took Margaret and later his father by boat to Sheerness, where he showed them over the port in which his naval service had begun sixteen years earlier and the Formidable, the vessel on which his court-martial had taken place.

Business of one sort or another also called Hannay away from London occasionally. More and more often, he was asked to lecture in various parts of the country, and he made one extensive speaking tour in Scotland, interrupted by the death of his infant son, in the late winter and early spring of 1858. In October of the following year, his assignment to write on the state of French naval preparedness took him on his first trip across the Channel. He spent most of his time in Cherbourg, but also visited Paris and traveled in Normandy.

By all odds the most exciting of these excursions came in the spring of 1857, when Hannay traveled to his native city to contest 
the seat for the Dumfries District of Burghs in the General Election of that year. As we have seen, Hannay had long been interested both in politics and oratory; this seat was of particular interest to him, having been twice contested by his father in the 1830's; and the incumbent M.P. for this constituency, William Ewart, was a man of whom Hannay did not have a high opinion. In June 1856 Hannay had referred to Ewart, in one of his "London letters" to the New York Tribune, as "a little, common-looking weak creature, of Radical politics, but of no brains to make his politics of any importance. Capital punishment is his great subject, and he harangues so heavily against it that he defeats his own subject, by making people wish him hanged himself!" (24 June 1856, p. 6) A few days later, in connection with the agitation surrounding "Saintly Billy" Palmer, Hannay dismissed Ewart as an "abjectly feeble ... bore" on the subject of the death penalty (28 June 1856, p. 6). (In point of fact, Ewart had served a long, moderately distinguished career in Parliament, which began a year after Hannay was born, and had been responsible, among other things, not only for an act of 1837 which restricted capital punishment, but also for a far-reaching bill passed in 1850 establishing free public libraries.)

At any rate, after Palmerston's government was brought down on the China question on 3 March 1857, Hannay saw his chance to enter public life. Accordingly, he sent the following Address, dated 14 March 1857, to the rather startled electors of Dumfries, who had not seen their constituency contested in sixteen years:

ACCORDING to the forms of the Constitution under which we live, you will soon be called on to exercise your elective franchise. I have the honour to announce my intention of becoming a candidate for your suffrages. Of my personal pretensions, it becomes me to speak with great modesty. As a native of Dumfries, I am especially interested in your district; and my occupations have naturally led me to bestow much attention on those social and political questions which affect the interests of great communities. If you are pleased to elect me, I can promise, at least, a faithful devotion to public subjects, and that I will never sacrifice my independence to my ambition.

Had it been my lot to represent you during the recent Chinese Debate, I should certainly not have evaded the momentous division which closed it. At the same time, I am bound to say that I do not think the offence given by the Chinese on the 8th of October justified the terrible chastise- 
ment which followed. With every respect for Lord Palmerston, and especially for his great services in the Russian War, I am not prepared to follow his guidance, blindly, in any matter.

It is difficult to use Party appellations in these days, without exposing oneself to being misunderstood. I am firmly attached to the great institutions of the kingdom. Nevertheless, there are anomalies in the representative system which I should be glad to see abolished; and I will never join that numerous class who refuse to remove what they themselves admit to be abuses, from an abstract dislike to all reform.

I will assist to the best of my power in keeping the pressure of taxation off the industry of the kingdom; and in checking the growing increase of expenditure which so strongly marks the present day.

I am earnestly bent on taking an active part in the various Social Reforms which now wisely occupy so many minds. I am strongly zealous for Education-for Emigration-for Army Reform-and for employing the principle of Competition as a check on patronage in the Public Service. Such social questions seem to me the most important ones of the time, and they ought to be urged constantly on our statesmen.

To carry out such a policy as I have indicated, we require peaceful relations with foreign countries. Let us be prepared to fight on vital questions, and let us refrain from irritation about ordinary ones.

As a Scotsman-fond of the history of his country and proud of its renown-I shall ever be ready to bestow my best attention on Scottish subjects. There is a tendency to undue centralization-a neglect of Scottish nationality and interests-which I decidedly think demands our constant watchfulness.

I am, Gentlemen,

Your faithful, humble Servant, JAMES HANNAY.

Canonbury, London, 14 March. ${ }^{39}$

On 19 March, Hannay left London by train for Dumfries, where he spent the next ten days giving speeches and canvassing voters, enjoying himself hugely and making a great impression on all who heard him-most of whom, unfortunately, did not qualify as electors. Perhaps his greatest triumphs were a speech at a public meeting in the courthouse on 27 March (according to the diary, delivered "to an immense audience-the most successful of all my speeches during the contest") and his appearance the next afternoon at the formal nomination on the evergreen-bedecked hustings which had been erected in Queensberry Square. On the latter occasion, he was greet- 


\section{JAMES HANNAY}

ed "with deafening cheers, again and again renewed," and captivated his audience with his remarks, of which the following, as reported in the Dumfries Courier of 31 March 1857, is a fair sample:

They were asked to give the preference to his honourable opponent because he was a tried man. That was a claim that would accumulate from year to year, and at the end of 50 years of course Mr. Ewart would be 50 times fitter to represent the constituency than now. (Great laughter.) It was a claim that could be made if he lived to the age of Methuselah, and he would certainly be very well worthy of being the representative of their grand-children and great-grand-children if that principle were admitted. But there was an end to that sort of thing, and Mr. Ewart having been 29 years in the House of Commons, during 16 of which he sat for these burghs, had had his fair share, and ought to make way for a younger man. (Cheers and laughter.) (A voice on the hustings, near Mr. Ewart, "That's certainly a new argument.") He admitted it was a new argument, perhaps a personal one, but his honourable opponent had had too much experience on the hustings not to know that a man in his position was entitled to do the best he could. (Cheers and laughter, and "Hear, hear," from Mr. Ewart.) How could they know what sort of man he was till they tried him; they did not know whether gold was gold or not till they put it into the crucible-(cheers)-and he was sure that his honourable opponent, if, when he first stood as a candidate for Parliamentary honours, he had been told by his opponent that he was an untried man, would have said, "You don't know what is in me, and I want you to try." (Cheers.) Well, he (Mr. Hannay) was now 30 years of age-(cheers)and if there was anything at all in him-except, as the Scotch people said, "what the spoon put in him"-(laughter)-any capacity to take a part in public affairs-it was surely now; if not he would never be fit for anything at all. (Cheers.) A member of Parliament was eligible at 21, and Charles James Fox and Earl Chesterfield, as Lord Stanhope, had entered Parliament even earlier. If a man were to sow his wild oats at all-supposing him to have that agricultural process to go through-(laughter)they ought to be sown by the age to which he had arrived. (Cheers.) If they compelled him to return to London "beaten but not dismayed," they would deprive him of the best five years of his life- (great laughter)for he was not going to run about from constituency to constituency, but would wait till the Dumfries burghs should choose him. (Cheers.) All the great things that had ever been done in the world had been done by young men, and nothing, he believed, had done so much harm to the cause of progress as elderly gentlemen. (Roars of laughter, in which $\mathrm{Mr}$ Ewart joined.) 
At the show of hands which the Sheriff called for after both candidates had made their speeches, the admirers of Hannay in the crowd (largely composed of non-electors) clearly outnumbered Ewart's followers.

Throughout his brief but vigorous campaign, Hannay repeatedly made the same main points: he was not a Conservative who had come to oppose the Liberalism of the incumbent, but rather an independent who might very well vote with the Liberals on any issue if led to do so by principle and conviction; he represented the interest of culture and letters-an interest which ought to be heard in the councils of a great nation; England must look to her own problems instead of stirring up trouble in foreign countries; and, above all, the future of the nation and the well-being of all classes in society rested, not in any short-sighted scheme of reform, but in "the great institutions of the kingdom"- "the monarchy, the aristocracy, and the national churches." These phrases occurred in the first public address Hannay gave in Dumfries, on 20 March 1857; in this speech, reiterating beliefs which he had held for many years, he said he had two reasons for regarding the established institutions as he did:

First-because where three men of average ability hold any opinion against a fourth, the probability is that the three are in the right, and the fourth is wrong; so ten or twenty generations might be said to be wiser than one, and as they had approved of our national institutions, and appeared to have the best of the reasoning, we should adhere to them as long as possible. Then, again, he respected the aristocracy, not because they were "Lord" and "Sir," and rode in carriages, but because the order of our nobility had been founded on account of personal superiority and heroism, and because by their position and advantages in life they were the valuable and noble instruments of bringing about much real and practical good for society at large. He believed in the virtues of the aristocracy, but was attached to them from historical as much-if not more-as from modern or personal associations. The nobility might be said to be in the social system what the bones were in the human bodythey protected the interior life, the stomachic functions and lungs of the system. Had it not been for the feudal barons, the commerce of this country could never have grown up into what it now is, and the feudal system itself was a necessary state through which Europe had to pass. He respected such men as the Duke of Hamilton and the Earl of Galloway, not because of their titles, but because the one was the male de- 


\section{JAMES HANNAY}

scendant in a direct line from Archibald Douglas "Bell-the-Cat," and the other was the head of the house of Stewart since the death of the Cardinal of York. ... He did not come before the electors of these burghs with a few cheap sentences about the ballot and the suffrage, and expect them to believe that by means of such influences as these they would secure a better state of society. No, he believed rather in the efficacy of spiritual means-in the influence of our clergymen and our schoolmasters-good writers-honourable and benevolent noblemen-and the efforts of every earnest man who endeavours to do good as God has called upon him and given him the power-he believed in the efficacy of these means rather than in any mere transference of power from one set of men to another. ${ }^{40}$

In an article on "Electioneering" which he wrote for the Quarterly Review several weeks after his return from Dumfries, Hannay described the pleasures and especially the rigors of personal canvassing as it was practiced in his day:

The mental eye wearies of the kaleidoscope that has been turning before it for hours. The hand aches with incessant shaking. The head aches with incessant observation. You fling yourself wearied, at nightfall, into an easy-chair in your committee-room, and plunge eagerly into sherry and soda-water. You could lie down and sleep, like a general after a battle. But your Committee is about to meet, as a staring blue bill on the hotel wall informs the public; and a score of people have news for you. Tomkins the hatter is wavering-a man who can influence four or five; the enemy have set going a story that you beat your wife, and you must have a placard out showing that you are a bachelor; a gang are drinking champagne at the Blue Boar (one of the enemy's houses), fellows whose politics ordinarily are of the poorest kind; your opinion is wanted on a new squib; the manager of the theatre is below, waiting to see if you will patronise his theatre, one night early, and whether you will have "Black-eyed Susan" or "Douglas"; a deputation of proprietors of donkeys want to hear your views on the taxation of French asses' milk. Who, under such circumstances, can retain in his memory all the details of the canvass of the day?

And yet canvassing-if a man have a dash of Lord Wharton in himis a real pleasure, too. In no way can a man with an eye for character see so much character in a short time. The varieties of the genus voter are so infinite! There is the common dubious voter, a little shy as you enter, and who fumbles with something on the counter while you are talking. He has not made up his mind. He "pledges himself to no man." $\mathrm{He}$ "will see on Monday." You come away, doubtful, but feeling that you 
have a chance. The next voter is the bluff Briton, who "disapproves of your principles," and "tells you so frankly." ... These men have a sympathy with a ready stroke of wit which may get you their votes after all; especially if the opposite party should boast of their vote, in which case our friend is as likely as not to change his mind, only to show his independence. The worst kind of eccentric voter is the fellow who affects a rude familiarity first, and then votes against you after all; and an equally disagreeable specimen is your small politician who draws you into a discussion on politics that he may show off to his wife and the apprentice, duly intending, all the while, to plump for your opponent. These are the phenomena which make canvassing so admirable a test of the tact and temper of candidates. Again, a humorous constituent will sometimes hear you in inscrutable silence, and all of a sudden burst out with the fact that he has been pledged to you for a week. ${ }^{41}$

When the vote was held, on 30 March 1857, Hannay was decisively defeated, polling 185 votes against 506 for Ewart, but he had scored a kind of moral victory. He had fought a valiant battle against tremendous odds; he had won a great many admirers; and, of course, he had had a marvelous time (all this on money borrowed on his life insurance policy). Also, despite his protestations of independence, he had attracted the attention of influential Conservatives, primarily Lord Stanley, who were instrumental on two later occasions in securing important appointments for him. ${ }^{42}$ 


\section{Chapter IV: Edinburgh: THE Courant EDITORSHIP, 1860-1865}

During the summer of 1860 , Hannay was presented with an opportunity to exercise his peculiar combination of talents in a new sphere-an opportunity which he could not afford to turn down. The Edinburgh Courant, an old and renowned journal which had been politically neutral through most of its long history, had undergone a change in ownership and policy earlier in the year, and the new proprietors were seeking an editor to carry out its new role as an avowedly Conservative organ. Liberalism was all-powerful in Scotland at mid-century, and the most influential newspaper in Edinburgh in 1860 was the Liberal Scotsman, ably and energetically edited by Alexander Russel. The Conservative owners of the Courant hoped not only to restore the drooping fortunes of their venerable paper but also to make the voice of their party more clearly heard in Edinburgh and throughout Scotland. Lord Stanley suggested that Hannay might be their man; ${ }^{1}$ after an interview between Hannay and one of their agents on 20 July, they agreed, and Hannay was offered the post, virtually on the spot; and he accepted the editorship the next day. ${ }^{2}$

In many ways, Hannay was the ideal man for the job. For one so young (he was then thirty-three), he had had a great deal of experience in journalism: some of it as editor; much of it, more recently, in the workaday side of putting out, week after week, a paper devoted to balanced news coverage, responsible editorial comment, and perceptive attention to literature and the other arts. $\mathrm{He}$ had the youth and vigor necessary for the kind of battles which a militantly Conservative editor would have to fight in a Liberal city against all sorts of solidly entrenched foes. He was not only a Conservative (in his private, more than in the party, sense of the term), but a singularly articulate one, well able "to make my new editorship felt" 3 by the pungency with which he expressed his ideas. Though not every convivial young man with those qualifications would have been willing to forsake the pleasures of London for the comparative rigors of life in Edinburgh, Hannay, whose bank balance did not grow as his family did, must have been tempted by the salary; 4 and the prospect of exile-if exile it seemed-probably looked almost attractive to one with as many Scottish associations as Hannay. ${ }^{5}$ 
Accordingly, Hannay bade his London literary friends farewell at a dinner held in his honor at the Freemasons' Tavern on 9 Augusta successful affair, despite the offensive manner of Hepworth Dixon, editor of the Athenaeum, who was in the chair ${ }^{6}$-and, after a few more days' holiday at Worthing and some last-minute business in London, the family sailed for Edinburgh on the 22nd. There they moved into a furnished house at 28 Buccleuch Place, and Hannay assumed the duties of the editorship on 31 August 1860.

His diary trails off and finally stops in the autumn of that year, for reasons which are not difficult to fathom. Hannay was now responsible for supervising the publication of eight papers a week-a daily number each weekday and semi-weekly editions on Tuesdays and Fridays. He also wrote most of the long leading articles, at least a fair number of the major book reviews, and no one knows how much of the rest of the material in the paper during nearly four and a half years, ${ }^{7}$ and he continued to engage, though on a much reduced scale, in the sort of literary work he had done before coming to Scotland. ${ }^{8}$ In a sense, the Edinburgh Courant during the period September 1860-February 1865 is Hannay's diary: though it tells us little of his movements and nothing of his personal life (beyond the periodic announcements in the "Births" column of additions to his family), it shows very clearly in the leaders and elsewhere what he was thinking about issues of the day and how he brought his political and philosophical convictions to bear on the events chronicled in its news columns.

These were exciting years to be an editor. In Europe, Italy and Germany were painfully and often violently straining to become modern nation-states. The Russian and Austrian empires were swaying before the winds of change. Napoleon III was an inscrutable, probably malevolent force, and at the beginning of the decade huge armies of Volunteers were training all over the British Isles in anticipation of an invasion from across the Channel. The thought of a general war was never far from men's minds, and something very close to the real thing erupted in the German-Danish conflict over Schleswig-Holstein in 1864.

Overseas, the American Union broke up and the Civil War broke out and dragged on, to the fascination and usually the horror of European observers. The work of building and maintaining the 


\section{JAMES HANNAY}

British Empire proceeded apace, with all sorts of reports of triumphs and troubles coming in after many weeks from such remote regions as India, China, and Australasia. In Egypt, the Suez Canal was slowly being dug, despite British opposition.

At home, the Liberals under the aged Palmerston kept a weakening grip on the reins of government. Social unrest was not what it had been earlier in the century, but still there was much talk about electoral reform. Industry, commerce, communications, and of course the cities with all their physical and human problems went on growing. The Church of England, having survived the Oxford Movement, was beginning to face the more serious threats posed by modern science, the Essays and Reviews, and the writings of Bishop Colenso. In Scotland, Presbyterian factionalism continued undimished, with the Established and Free Churches vying for dominance. Despite republican murmurings, the strength of the monarchy seemed unshaken; and the British people grieved at the death of Albert and rejoiced at the coming of age of the Prince of Wales and his marriage to Princess Alexandra of Denmark.

It is difficult to see how any provincial newspaper of that time could have done more to keep its readers abreast of these and other matters than did the Courant under Hannay. In dealing with events that occurred in or near Edinburgh, such as disastrous accidents or meetings of General Assemblies, presbyteries, and the Edinburgh Town Council (which often struck Hannay as disastrous too), the Courant was able to produce truly massive coverage. For its longer reports on foreign affairs it frequently had to rely on material from the Times (whose politics Hannay regularly abused in his editorial columns) and other London papers. Whatever its sources, however, the Courant consistently reflected with reasonable accuracy and in some detail what was happening in the world. It paid due attention to literature, music, and art, and carried the usual news of business, agriculture, and sport in respectable quantities. Finally, it is impossible to forget in going through the files of the Courant for these years that one is reading a Scottish newspaper. Quite properly, there is a great deal of Scottish news, and much stress is placed on the Scottish bearing of events occurring south of the Tweed. Hannay did much in his leaders to foster what he considered the desirable aspects of Scottish national and Edinburgh local feeling, reminding 
his readers repeatedly of the great traditions which they should regard as their trust. Nevertheless, he always protested against narrow-minded provincialism or chauvinism, which he was careful to distinguish from true Scottish nationalism. "We yield to none in a sincere affection for Scottish traditions, nor in a readiness to rebuke anything that could be construed as an insult to the country. We wish, however, to learn from the nation's faults, as well as to profit by its virtues, and therefore we pay attentive regard to whatever criticism those faults provoke" (20 May 1862, p. 2). ${ }^{9}$

By such standards, then, Hannay seems to have been a conscientious and successful editor, one who bore in mind the needs and interests of his readers without truckling to them. He was equally aware of his obligation to represent the Conservative cause in Edinburgh. Predictably, his editorials attacked the speeches and policies of Palmerston, Russell, and Gladstone and praised those of Derby, Disraeli, and his special patron Lord Stanley; every Liberal blunder was hooted, every Conservative victory hailed-and, of course, the Liberals scored no victories and the Conservatives committed no blunders. But many of Hannay's editorials rise above mere party-line journalism, and here lies their interest for us: they show him to be a man with well-formed intellectual convictions, which, however unreasonable they may seem today, are certainly consistent, grow clearly out of his earlier beliefs, and can be made to give a plausible shape to the events which he attempts to interpret with their aid.

It was typical of Hannay that he chose to set forth the principles of Conservatism as he understood them in the very first leader he wrote for the Courant. The basic credo of Conservatives, in his view, was that the historic "institutions of the kingdom constitute a suffcient machinery for effecting whatever is needed by the kingdom. We begin by accepting the past as good-and the Constitution as an inheritance which it is our first duty to preserve, even if we think we can improve it." In this, the Conservative is opposed not so much to the Whig as to the sort of radical or democrat whose thinking (if it can be called that) is more and more coming to dominate the Liberal party. For such a man is a theorist, an abstractionist, and the British Constitution, which Conservatives want to uphold above all, has evolved in defiance of theories and abstractions. "He believes in 


\section{JAMES HANNAY}

numbers, and a Conservative in interests. He thinks that the many are right, simply as the many. A Conservative knows that truths originate with the few, and spread downwards. The Democrat fancies that the popular part of the Constitution has done everything for it; but he forgets that it would have been ruined had the popular part ever got the upper hand." The old Whigs, like Palmerston, who are still at the head of the Liberal party are acutely uncomfortable in the company of their radical colleagues; they are really semi-Tories rather than semi-democrats. "A Whig treats the aristocracy with respect-we will fight for them. A Whig is civil to the Church-we honour it. A Whig is not opposed to the landed interest-we think that it ought to retain the leadership (we do not say the unbounded control) of the State." If they have moved more and more toward the ideas of men like Bright, Cobden, and Roebuck in recent years, this is not so much from conviction as from the fear that only by making such concessions can they stay in control of their party and the government.

No one should assume, however, that Conservatism is so enamored of the past as to resist all change. "With the results of all natural and spontaneous changes-those which society makes for itself-Conservatism has as much right to deal as Liberalism. But there is another kind of change-which ignores traditions, and deals with existing society as so much carte blanche-which measures Great Britain by the standard of countries in quite different circumstances, or tries to reform it on abstract and ideal principles. With this, Conservatism has nothing to do but to resist it, wherever it may be met in literature, society, or politics" (1 September 1860, p. 2).

None of this, of course, is really new. It is Burke brought up to date, Coleridge and Carlyle made intelligible to readers of a daily newspaper-in itself no mean achievement. Moreover, as a political philosophy it fits in, not only with Hannay's cherished beliefs about "blood and culture," but also with the trend of much of the news on which he was called to comment in his editorials.

For example, there were the dozens of leaders which Hannay devoted to American affairs in the years 1860-65. Not surprisingly, Hannay, like many British editors during the Civil War, supported the cause of the South. But there was more in his opposition to the Union than anger at Yankee highhandedness at sea or distress at the plight of the 


\section{EDINBURGH: THE COURANT EDITORSHIP, 1860-1865}

Lancashire cotton industry (though these were factors). Much more fundamental was Hannay's view of the struggle as a conflict between the forces of conservatism-aristocracy, manners, tradition-in the South and those of democracy-coarseness, cruelty, lack of distinction of any sort-in the North.

Occasionally, however, one does sense that Hannay's strictures on the Civil War grow largely out of his disgust with its aesthetic defects. Passages like the following occur a number of times in his editorials:

You might as well try to get the funeral oration of Pericles out of Mr. Lincoln,-or to find a General with a face like the Strafford of Vandyke,as to kindle in the European imagination any such feeling about the contest as is kindled by the page of Thucydides or Clarendon. The whole spectacle has a bourgeois and prosaic character;-is horrible without being tragical,-and vast without being grand. We doubt whether it will produce any literary result as good as those ballads which the little border skirmishes of our ancestors with the English used to give birth to. A series of struggles between negro-owning Cavaliers and shopkeeping Roundheads has something vulgar about it,-which cannot be laughed at, because bloodshed is part of it, but which lays no hold on the imagination or the subtler sensibilities of mankind. Not a single great man has yet appeared on either side; -not a noble saying ever has found its way to Europe amidst the mass of inflated and immoral newspaper stuff to which the war has given rise (13 June 1862, p. 2).

On the whole, however, he left no doubt that he regarded the Civil War as a horrible cautionary tale, showing Great Britain what it might expect if it proceeded on the path of "Americanisation." This process involved a number of dangerous steps. It meant, first of all, regarding the national constitution as something that could be tinkered with as the whims of various interested and powerful factions dictated. In its origin as a deliberately drafted document, the American Constitution was, to be sure, different from and inferior to the British, but as a work "to the formation and perfection of which some of the wisest and best men of past times have devoted their lives and labours" it was certainly the next best thing. Hannay did not do much to support his case with detailed evidence from pre-Civil War American history, but it is clear that he meant to show his countrymen the dangers of indiscriminate and successful radical 


\section{JAMES HANNAY}

assaults on time-tested institutions. "A rabid rage for reform, and for giving political power to those unfit to use it; a mingling up and confounding the legislative, executive, and judicial departments in the State, which it is so essential to keep distinct; and a foolish weakening of the executive and judicial powers; have gradually prepared the way for the breaking up of that Union, which once held together, as in a bond of brotherhood, the various States of the American confederation" (30 January 1861, p. 2).

Democracy, which Hannay always equated with putting the control of the affairs of government into the hands of ignorant and venal men, gave a great nation like the United States a leader like Lincoln in its hour of crisis-and Lincoln at best was ineffectual. After his inauguration, Hannay viewed the new President as "a mere second-rate lawyer, who in England could hardly aspire to be Recorder of a country town"; Lincoln's first inaugural address was "a speech the wisdom of which consisted in professing nothing, and the eloquence of which would have been hissed at Sadlers' Wells" (20 March 1861, p. 2); and his character was described at the time of his re-election as that of "a ruler who has already proved himself a hopeless mediocrity-a man without the commonest education, lowminded, vulgar, and a buffoon" (23 November 1864, p. 2).

The moral fervor of the American abolitionists and their British sympathizers struck Hannay as dangerous in the extreme-not because moral fervor per se was a curse or slavery a blessing, but because it seemed to Hannay to show how passionate zeal in a sound cause might be put to damaging uses. The Civil War, he insisted, was not primarily a war about slavery, though it might appear to be that to starry-eyed and simple-minded people: it was a war between two opposed social, economic, and philosophical systems in which slavery was but one of several factors. And, ironically, the war would do more harm than good to those whom the abolitionists professed to be trying to help, the Negroes themselves. "The supreme interest of the negro is that he shall live under a settled, peaceful government, with masters able and likely to be kind to him, till the freedom of his race is gradually worked out by moral and economical changes, in the persons of his descendants. But the first step towards such a future is that the South shall be delivered from the necessity of struggling for a political existence. And every man retards the cause 


\section{EDINBURGH: THE COURANT EDITORSHIP, 1860-1865}

who does anything to aid Mr Lincoln in his present cruel, ambitious, ill-conducted, and hopeless war of conquest" (20 February 1863, p. 2). Like most democratic sloganeering, then, the ideas of the abolitionists were either hypocritical or self-defeating or both.

Everywhere in world affairs that Hannay looked he saw the dangers of creeping or galloping democracy and the benefits of more traditional systems of government. Neither the individual citizen's exercise of the franchise nor self-determination on the part of peoples subjected to foreign rule, which together comprised the menacing "Spectre of Revolution" (22 March 1861, p. 2), held out anything but danger to all involved. The initial successes of the French adventure in Mexico, for example, led Hannay to indict "that democratic republicanism" under which what had been Spanish America had alternately seethed and stagnated since achieving indeplendence. "Scarcely a year passes without a political explosion in one or other of these republics; and if anything could avenge the Spanish Crown for the loss of its former possessions, it would be the national disgrace into which the rebel colonies have since been plunged. In the opinion of all dispassionate and competent observers, nothing but European intervention will raise these republics from their social and political abasement. Nothing but the re-establishment of monarchical institutions will restore the Creole race to that prosperous tranquillity from which it has been so long estranged" (20 May 1863 , p. 2). Even the Ionian islands, which Hannay had come to know first-hand as a youngster, had been infected by the virus and were growing restless under benevolent British rule. "Few creatures are more contemptible than an Ionian Greek. In blood a mongrel,-in habits a fribble,-a babbler from the cradle,- he has just brains enough to pick up the watchwords of revolution and to give them out in the declamatory style of the South. He, too, has been bitten by the 'Nationality' mania, and as he absurdly supposes himself sprung from the old Greek heroes, he esteems his nationality the most noble of all... . We may laugh at the falsehoods against our administration of a people whom Nature seems to have intended for billiard-markers and keepers of cafés. But when we consider that Europe at this moment is at once agitated by visions, and undermined by intrigues, -we can afford to despise nothing" (22 March 1861, p. 2).

As to universal suffrage, this could only grow out of a foolish 
and dangerous misreading of human nature and human experience. At the news that the people of Naples were going to vote on their political future in November 1860, Hannay made his feelings on this point quite clear. "The notion that all men are politically equal -equally wise for State purposes; proper to be told off by the head as units of similar value-or weighed in masses like inanimate things -is unknown to the Scripture, the ancients, or our own ancestors alike. If based on the notion of there being any real equality between human beings, it is contradicted by the experience of every family-of every street-of every occasion on which men are thrown on their own resources to form a society, together, for any purpose. If tried by the test of experience, all experience is against it" (23 October 1860, p. 2).

Ever the disciple of Carlyle, Hannay insisted in the same leader that great movements benefiting the many invariably originate in the minds and works of "a few wise men," and he always held that there was more likelihood of tyranny under democracy than in an aristocratic or an oligarchic system of government. In May 1864, for instance, he could hardly conceal his satisfaction at the ironical fact that the Corps Législatif, with the blessing of Napoleon III, had acted to relax the restraints under which French trade unions had long chafed. Nor was this a unique instance. "Our combination laws were repealed by an 'unreformed' Parliament; those of France were imposed by the Revolutionary Assembly of 1791. Even that latest form of them, considered by the Imperial Government itself oppressive to the French working classes, was fixed by the Republican Assembly of 1849 , which owed its existence to universal suffrage" (10 May 1864, p. 2).

Edinburgh itself furnished Hannay with an edifying example of the baneful effects of democracy. At the beginning of his Courant editorship, the Edinburgh Town Council was controlled by advanced Liberals and Hannay took great delight in ridiculing that body in his leaders. Edinburgh, which had once proudly and deservedly borne the designation "Athens of the North," was now comparable to the ancient Greek city only in having rulers as inept as those whom Aristophanes satirized (10 November 1860, p. 2). Fortunately, they were "feeble and obscure" as well, so that Punch had not found them of sufficient interest to expose them and their city-"once 
governed by Forresters of Corstorphine and Douglases of Kilspindie, -the ancient seat of a court and a Parliament"-to national ridicule and contempt (20 December 1860, p. 2).

Why, then, devote so much attention in the Courant's news columns to the proceedings of a group consisting largely of "obscure and illiterate bores"?

To this kind of remonstrance, we generally reply, that fun is often to be derived from the strange intellectual gambols of the crew in question; and that our subscribers ought to be glad to get, for next to nothing, an amusement which cost their ancestors in old times the whole keep of a Fool. Besides,-we say,-consider the service that is done by this queer body of men to the cause of good government! If Democracy palpably results in exhibitions of this kind, how much does the fact strengthen those who consider it an impracticable form of government! Just think how often shrewd working men as well as observing middle-class men must be deterred from extreme views by seeing the figure cut by Councillor MacSumph or Bailie Littlebrain! (21 March 1861, p. 2)

"We firmly believe," he wrote, "that the municipalities,-the great metropolitan vestries at their head,-have done more to sicken the British people with democracy than any other influence whatever" (27 September 1861, p. 2).

It is not surprising, then, that Hannay's leading articles showed no sympathy toward suggestions for further electoral reform: this was not what the country wanted, he insisted; and he anticipated his modern successors by seizing on every by-election result as indicative of the trend he most wanted to spot. Nor could he see any virtue in the ballot, which would only add to the dangers of a procedure already sufficiently hazardous: "every vote dropped into the ballot-box will be a nail in the coffin of our greatness" (5 July 1862, p. 2).

Nevertheless, we must not make the error, however backwardlooking many of Hannay's views strike us today, of painting him as a black reactionary. As he had insisted in his initial editorial, enlightened Conservatism did not blindly oppose all social and political change, and one should not be surprised to find in this follower of Carlyle and admirer of Disraeli a concern for the well-being of the lower classes and for the unity and integrity of the whole social order, co-existing with his admiration of aristocracy and his profound mistrust of radicalism. ${ }^{10}$ In writing on such issues of the day as 


\section{JAMES HANnAY}

sanitary reform and adequate housing, Hannay was invariably on the side of progress. He also joined the Quarterly Review in applauding the growth of the co-operative movement, pointing out that Conservatives like Southey had long ago championed such societies, despite "liberal" opposition and ridicule. "Anything that makes the working man an owner of property, an employer of labour, instead of a mere worker for wages, assimilates him to the classes above him, and imbues him with their attachment to constitutional order" (30 October 1863, p. 2). In another leader, calling attention to the many instances of mismanagement and corruption to be found in the rapidly multiplying "friendly societies" which were established to provide some small measure of financial security for poor people, Hannay seemed to be anticipating the welfare state by suggesting that the government step in, "to develop further the principle of the Post Office Savings Banks, and to afford the working classes of the country, in return for contributions equitably adjusted, a guaranteed provision for sickness, old age, and the payment of a sum after death" (18 November 1863, p. 2).

Hannay's most pungent editorials were generally devoted to local issues, but he lost no opportunity to point out the wider bearings of these apparently parochial matters. For one thing, he made no secret of his support of the Established Churches of Scotland and England, and every time a prominent Free Church divine uttered an important pronouncement in Edinburgh he could be reasonably sure of seeing not only a detailed report but also a leader critical of his speech in the Courant the next morning. Hannay could never forgive the Free Church for breaking away from the Establishment and repeatedly condemned its clergy for what he took to be their fanaticism, narrow-mindedness, hypocrisy, demagoguery, and (not least important to Hannay) lack of learning.

None of the Free Church clergy, not even the revered Dr. Thomas Guthrie, was immune from Hannay's assaults, but his favorite target was Dr. James Begg, minister of Newington Free Church. Like Guthrie, Begg had been a chief agent in the Disruption of 1843, and his theological views were if anything even more inflexible than those of his colleagues. Politically, however, he held some advanced notions which he took every occasion to put forward in uncompromising terms. It was this "radicalism" of Begg's, no doubt, 


\section{EDINBURGH: THE COURANT EdITORSHIP, 1860-1865}

which particularly drew Hannay's ire. For Begg, even more than other Free Church leaders, tended to blame the upper classes for the misery of the poor, and this to Hannay was sheer "ecclesiastical demagogy." In November 1861, for example, when a tenement collapsed on the Edinburgh High Street, killing and injuring many people, Begg (surely with some justification) attacked the negligence of landlords which made such disasters possible. Though Hannay, of course, deplored the tragedy and the conditions which brought it about, he was scornful of Begg's attempt to capitalize on the situation. "Among the minor calamities which follow in the wake of such accidents ... are the harangues of clerical demagogues and of popular preachers. [After the initial shock and pity for the victims] it occurs to Dr Begg that it might be as well to pour a little oil-of vitriol,into the wounds which divide the lower orders from the upper; and forthwith the occasion is improved by a harangue in which the 'landlord classes' are denounced as the chief authors of the tragedy" (3 December 1861, p. 2).

"The Doctor," Hannay had written on an earlier occasion, "is a sort of ecclesiastical demagogue-a Free Church Mr Bright-distinguished for his loudness of assertion, coarseness of language, virulence of tone, and carelessness of facts." $\mathrm{He}$ indulges in "ecclesiastical Billingsgate, which flows from his mouth as naturally as mud from a sewer" (21 August 1861, p. 2). Perhaps worst of all, Begg's diatribes do more to stir up antagonism between class and class than to help those in whom he professes to be interested; and, in Hannay's view, if there is anything which must at all costs be avoided it is class warfare.

Though Hannay sympathized with Begg's strict sabbatarian views and some of the conservatism of his theology, almost any other opinion which Begg expressed was likely to receive rough treatment in the Courant's editorial columns. On one occasion, for instance, Begg, disturbed by the dearth of qualified candidates for the Free Church ministry, publicly suggested that the universities provide early morning and evening classes for "aspirants to Free Church pulpits" who were unable to take the normal theological course of study and who worked during the day. Hannay greeted this proposal with derision. Admit shop boys to the ministry? Begg's scheme amounted to a confession of the Free Church's inability to attract a learned 


\section{James Hannay}

clergy, and, if adopted, would depress scholarly standards among ministers still further (31 March 1862, p. 2). These standards were already alarmingly low, particularly in the Free Church, whose clergymen were notably indifferent or hostile to learning. "They are always talking of the Bible,-by which they mean the Authorised Version. But they never produce anything in theology or scholarship. They never edit the Septuagint or the Greek Testament. They never make a contribution to ecclesiastical history or sacred philology. They never defend the faith against the sceptics of England, or France, or Germany. The result is that they have abundant leisure to employ in teaching the lairds their social duties, and in criticising the conduct of those Churches for which the lairds show such a perverse preference" (24 November 1864, p. 2). ${ }^{11}$ Again, Begg was a case in point. In one of his leaders on the "Sunday question," Hannay used Begg to help him establish a pair of key definitions. "By general consent, works of Necessity and works of Mercy are allowed upon the Lord's-day. For instance, were Dr Begg to read a Greek Father on that day, it would be a work of Necessity for him to use a Dictionary, and it would be a work of Mercy to lend him one!" (30 September 1863, p. 2)

To be sure, Hannay recognized that this problem of an unscholarly clergy, though especially acute in the Free Church, was not peculiar to Dr. Begg's denomination, and affected even the Established churches. ${ }^{12}$ At a time when Christian orthodoxy was being subjected to assaults from all sides, no church could afford the luxury of spokesmen who were unable to refute its learned antagonists point by abstruse point, and one of Hannay's rare attacks on an eminent member of the Church of Scotland grew out of this conviction.

In 1864, Principal John Tulloch of St. Mary's College, St. Andrews University, published The Christ of the Gospels and the Christ of Modern Criticism, a series of lectures purporting to reply to Ernest Renan's Life of Jesus. The Courant review of the book, undoubtedly the work of Hannay, ${ }^{13}$ began, rather gently, by arguing that Tulloch did not consider Renan's work in the proper light-as "Renan's portrait of Christ, just as there are portraits of Him by Rembrandt and Rubens," "the natural,-we may add the essentially democratic,-result of a union of the sentimentalism of Rousseau 
with the criticism of Germany." It was far more serious that Tulloch's learning was not sufficient for the task he had undertaken, and this was deplorable not only because it weakened his case but because it showed how low the state of scholarship had sunk even in the Established Church of Scotland. "In the 220 pages of his little volume, not above a dozen or sixteen are devoted to criticism proper, and it is difficult to find anything poorer than the criticism is. On the oriental ground, he never meets Renan at all, and even when Greek is in question, he is in a melancholy plight." By his own confession, Tulloch had only recently studied for the first time as important a writer as Philo. "The exquisite naïveté of this, from a man who has for years been a Doctor of Divinity, and held a Divinity Chair, is truly delightful" (30 July 1864, pp. 2-3).

Quite naturally, an editor holding Hannay's views about the value of the classics might be expected to defend their intrinsic worth as well as their merely practical function in the education of a churchman, especially in an age when many held that the extension of knowledge in the physical sciences rendered the traditional classical curriculum obsolete. Hannay's answer to such arguments was much like that which Arnold was to give Huxley: "It is only certain individuals who can be engineers, or astronomers, or chemists; but it behoves every man, as far as in him lies, to learn the laws of taste, of ethics, and of politics. Of these three catholic branches of human culture the dead languages contain the models; and therefore it is that the wisdom of all ages has selected them for the part they now play in education" (4 October 1862, p. 2).

In view of this, Hannay regarded it as particularly deplorable that the teaching of the classics at the University of Edinburgh should be entrusted to two men whom he considered quite unfit for their positions. Latin was the responsibility of Dr. James Pillans, an octogenarian who had held the Chair of Humanity since 1820, and was visibly and embarrassingly declining by the early 1860 's. Because of the crucial importance of the subject, Hannay in several editorials suggested pointedly that the time had come for Pillans to retire, and retracted nothing he had said about him when the old man died in 1864, the year after he finally gave up his chair. "As years rolled on, the Professor's scholarship grew no better, while his capacity to impart it grew worse... His decay, in fact, became painfully 


\section{James Hannay}

apparent to everybody but himself, yet he still stuck to his chair with a pertinacity distinctly injurious to the interests of the University" (5 April 1864, p. 2).

But Hannay's treatment of Pillans was gentle compared to his assaults against John Stuart Blackie, the Edinburgh Professor of Greek. In Blackie, Hannay took on a formidable foe indeed, a man who was known throughout Scotland as a "character" and a witty popular lecturer on all imaginable subjects. As his fame grew, so did his eccentricity and conceit, and his scholarship, always erratic, was pushed into the background of his crowded life.

Hannay seized every opportunity to pour scorn on Blackie's deportment and his learning. When, for example, Blackie delivered what Hannay considered a flippant speech in Glasgow on "The Advantages of a University Education to a Mercantile Community," Hannay took a grave view of the performance. "Every man has his business, and it is the business of Professor Blackie to teach Greek. Every profession has its character, and we expect from the scholar a certain severity, not necessarily ungenial, but quite different from the gaiety of a magazinist" (5 December 1861, p. 2).

Many other leaders attacking Blackie appeared in the Courant, and Blackie was almost unique among Hannay's victims in attempting to reply in kind-in letters to the editor, on the lecture platform (Blackie once referred to Hannay in public as an "Anglified puppy"14), and even in his classroom. Naturally, this did not increase Hannay's admiration for the man, and at the conclusion of an especially violent (and entertaining) exchange, on the subject of Scottish nationalism, Hannay had this to say about his antagonist:

He is forcing people to see in the Thistle not-what we are proud to see in it,-a beautiful old symbol,-but an article of refreshment giving certain creatures strength and spirit for a bray! . . Mr Blackie-if he had any real influence in England, would undo all that Sir Walter Scott did for us, there. But, luckily, such as his celebrity is, it is quite local,-and fast becoming ridiculous. Nobody would complain of his making a merryandrew of himself, if his doing so did not throw a kind of discredit on the Greek Chair. We all know, of course, that he got that Chair as the result of a sectarian compromise under a bad and effete system of patronage. But by solidly applying himself to its duties and studies, he might have caused this to be forgotten. Unfortunately for the Scotland which 
he professes to love so much, he has frittered away his time on agitation, and Greek Literature and Greek Scholarship owe nothing to his tenure of an honourable and profitable post (7 January 1862, p. 2).

One subject which brought Hannay and Blackie into particularly sharp conflict was the question of the length of the university session. The academic year at the University of Edinburgh at that time was only six months long. Hannay believed it ought to be extended to nine months, as part of a comprehensive scheme to improve higher education in Scotland. Blackie, on the other hand, was opposed to prolonging the academic year, for a number of reasons. Among other things, he said that professors needed their summers (six months!) for recreation and research, and that much of the additional teaching which reformers wanted to see the universities undertake was really "schoolmasters' work," which it would be better to attend to before students began their higher education. Hannay replied to these arguments in a withering editorial which might have been rather less violent if some months before he had not met Professor Carel Gabriel Cobet of Leyden, whom he ever afterward considered the ideal university classical scholar:

Mr Blackie has a way of talking in public as if he were too good for what he calls "schoolmasters" " work, but this is just what he has never condescended to prove. He has edited nothing, -he has written nothing,-in the departments of the higher scholarship; and that, in spite of a salary which would be thought respectable, and a leisure which would be thought extraordinary, either in Holland or Germany. Our deduction from this would be that such a man might legitimately be called upon to do more than he does at present, of the only classical work that he world gets out of him. All his declamation on the indifference of the Scotch public to learning - (though a good deal borne out by his own appointment to the Greek Chair)-is away from the point. The point is, whether he ought to grumble at the prospect of having to do more work than he performs just now. And the answer to this must be got by comparing its quantity, quality, and remuneration, with those of the work of Greek professors in other universities. Take Leyden, for instance ... (3 November 1863, p. 2).

Not only local politicians, preachers, and professors were the victims of Hannay's editorial pen. Naturally enough, he had much fault to find with Edinburgh's predominantly Liberal press, especial- 


\section{JAMES HANNAY}

ly at election time. "English that would not get admission into the halfpenny papers of the London parishes, the organs of Finsbury and Marylebone;-slander as stale as the poisons dug up at Pompeii; -low jocularity like that of the Commercial Room of a country inn after midnight;-invective brandished as recklessly as the writer's knife when peas are in season,-these are everyday phenomena at such times in the 'Liberal' press of Edinburgh"' (14 April 1864, p. 2). Chief among these adversaries was the Scotsman, then as now the most influential Edinburgh daily. While Hannay was editor of the Courant, the two papers engaged in innumerable squabbles. Hannay repeatedly accused his Liberal contemporary not only of holding indefensible political ideas, but also of distorting its opponents' statements to suit its own ends and (this gave Hannay particular pleasure) of showing a deplorable ignorance of the classics, good English usage, and polite knowledge in general. Alexander Russel, the editor of the Scotsman, was no less forthright than Hannay, and he hurled the same sort of charges back at the Courant. Even the readers of each paper joined in the fun with numerous letters to the editor of their favorite condemning the sins of its rival; one enthusiastic subscriber to the Courant, who signed himself "A Reading Man," wrote long weekly letters to his paper for a time in 1863-64, each one pointing out in detail the grammatical, stylistic, and factual errors which the Scotsman had committed during the previous week.

Almost always this running battle between the Courant and the Scotsman (which probably did the circulation of neither any harm) was waged quite amiably, and Hannay and Russel personally were reputed to be on good terms with each other. ${ }^{15}$ But occasionally a note of acrimony made itself hcard. In November 1862, for example, the two papers (and their loyal letter-writing readers) quarreled for days about the precise location of Athens, after the Scotsman had employed the phrase "Athens on Egina" in one of its leaders, each accusing the other of gross ignorance of geography and literature. At this same time, there was a contest for the rectorship of the University of Edinburgh in which the Scotsman supported Gladstone and the Courant Stirling. (Hannay argued that Gladstone's scholarship, which the Scotsman and his other backers praised so highly, "exhibited much of the same specious unsoundness which the country has had cause to regret in his financial legislation" [15 November 1862 , 
p. 2].) Feelings ran high, and finally the Scotsman indicated that it was finding it difficult to keep its temper. If it were to adopt its adversary's mode of debate, the Scotsman said, it would have "to say (alas! with the added element of truth) that his accomplishments are those of a puppyish schoolboy, and his demeanour that of a London tavern-brawler. Let us rather, however, give him a morsel of parting advice. His ambition is to be regarded as in a peculiar degree a scholar and a gentleman; but the means he uses to that unattainable end are such as leads everybody to regard him only as in a peculiar degree a pedant and a snob" (14 November 1862, p. 2). Hannay took it all very well; this controversy with the Courant, he wrote, had introduced an unwonted vigor-"not of thought (of course), but of epithet"-into the Scotsman, and for this Edinburgh Liberals ought to thank the Courant, though references to the Scotsman's opponent's being "no gentleman" and "a London tavernbrawler" were uncalled for, and further signs of the weakness rather than the strength of the Scotsman's position. "We hope we may live to meet the Scotsman himself in a respectable London tavern before we die" (15 November 1862, p. 2).

On an earlier occasion, Russel had set down an amusing and revealing appraisal of Hannay and what he took to be Hannay's view of the Courant's rôle:

One of his missions is to take full charge of the statesmen of "the Conservative" party, and inflict condign punishment on any person who either dispraises them, or praises them amiss-the other is incessantly to inculcate, by precept and example, the power, pre-eminence, and necessity of "blood and culture." In the discharge of the first-named mission, our neighbour has constituted himself a cherub that sits up aloft in the High Street of Edinburgh, taking care of the lives and characters of Mr Disraeli, Lord Stanley, Sir John Pakington, and other great people. He appears to have information that those clients of his are always waiting anxiously to know what the Courant says; and that when anybody ventures the slightest dissent or complaint regarding them, they are miserable till he descends from his perch and spreads his wings around them. Especially our humble selves cannot utter a word of comment regarding anything they say or do, but he is down upon us in his capacity of guardian angel. We have, however, nothing to complain of him in that way, as to beak and claws-only we would suggest that his voice is un. pleasant, in so far as it sometimes utters misrepresentations of the plain 


\section{JAMES HANNAY}

words of his neighbours. But what we would beg chiefly to bring under his notice, is the fact that he is giving himself much unnecessary trouble. We are very much afraid that those great men whose praise and defence are so constantly in his mouth are not powerfully affected either by our attacks or by his vindications....

As to the "blood and culture" business, it is less any business of oursfor that mission our contemporary exercises less upon us than upon mankind at large. But, though far from grudging him his innocent if peculiar diversion, let us, in the spirit of brotherly kindness, drop the hint that that sort of thing may be carried even beyond the point called ridiculous. ... He will understand that we have no objection to "blood," and have a proper admiration of "culture"-but have also an opinion that there may be more than enough of talk, and especially of boasting talk, about such matters. It is quite possible for people to talk so long and so loud about "scholar" and "gentleman" as rather to suggest the idea of schoolboy and gentleman's gentleman (27 November 1861, p. 2).

Behind Hannay's crusades against all sorts of specific offenders, there lay, it seems clear, a deeper feeling of dissatisfaction with the whole milieu of mid-nineteenth century Edinburgh. Attached as he was to the glories of Scotland's past, but accustomed to the much more exciting tempo of life in London, he must have sensed a certain thinness in the spiritual atmosphere of the modern provincial city that Edinburgh had become. Occasionally this made itself felt in his leaders. When, for example, he stated his opposition to the movement to open the Botanic Gardens on Sundays, his editorial was no more eloquent in its plea for the retention of "the national Sunday" "in this age of materialism and Mammon-worship" as "one of the last securities left for the maintenance of a national recognition of the spiritual existence and immortal hopes of man" than in its indictment of the exceedingly narrow framework within which the discussion of such matters was carried on in Scotland. What can we say of a city in which the two sides of a great debate are upheld, respectively, by Dr. Begg and the Scotsman?

Probably it never occurs to the ordinary "Liberal," that Dr Begg is precisely the counterpart,-like in unlike-of his antagonist. He holds just the same position in Theology that the Scotsman does in Literature; and unfortunately the two represent,-in an exact equality of taste, acquirements, and ability,-the two main antagonisms of the period. Readers of the Courant are aware that we often differ seriously with Dr Begg. But 
it would be unjust to him not to point out, that,-as against his chief enemy,-his case is by no means so bad as some people may suppose. For, in the first place, Dr Begg has principles at his back better than himself; whereas the Scotsman (at all events in his more genial mood) is better than his merely negative principles. If Dr Begg's influence was pushed to its utmost, the worst that could happen would be that a too great austerity and narrowness would tinge the religion of the masses,whereas the Scotsman's jokes about clergymen's Sunday dinners and harvest thanksgivings only diminish the popular respect for existing institutions, and supply nothing in its place. Pushed to its utmost, that kind of agitation issues simply in the illiterate scepticism of the atelier, which is closely connected with Jacobinism and revolution. The real antidote to the mischievous element in Dr Begg is to be sought in erudition and politeness; and what we most value in Established Churches, is that they preserve a golden mean between fanaticism, and a spurious "Liberalism" which opposes it by something worse (24 March 1863, p. 2).

Certainly this feeling of dissatisfaction had a great deal to do with his decision to resign the Courant editorship-a decision which he announced on 5 December 1864. ${ }^{16}$ Before he left Edinburgh, a great public dinner was held in his honor at the Douglas Hotel on 24 February 1865 with Bishop Charles Wordsworth of St. Andrews in the chair, and there was great-though almost certainly unintentional -irony in the words of praise which the Bishop spoke on that occasion: "He has done his best to revive among us the old literary days of George Buchanan and Arthur Johnson, without the bitterness of the ecclesiastical spirit of those days; and, moreover, to combine with the solid erudition of that age the more elegant culture of the last century-the century of Hume and of Robertson, of Smollett and of Beattie-without its licentiousness and without its scepticism."17 For all his efforts, the "erudition" and "politeness" whose absence Hannay had lamented in his editorial on the Botanic Gardens and the Sunday question were no more of a force in Edinburgh at the end of his editorship than they had been at its inception. There was, after all, nothing any one man could do to restore the ancient luster of the Athens of the North or to retard what Hannay later called "the gradual decomposition of Scottish nationality, the steady, continuous transmutation of that nationality into provincialism,"18 and quite possibly Hannay's recognition of this inevitable failure had something to do with his giving up the fight at Edinburgh. 


\section{James Hannay}

The best evidence we have suggests strongly, too, that the financial position of the Courant became increasingly precarious as Hannay's editorship went on, and doubtless this also helped to bring about his departure. ${ }^{19}$ Though he afterward spoke of the years in Edinburgh, where he had gathered a convivial circle about him as he had done in London, ${ }^{20}$ as "the happiest and brightest" of his life, ${ }^{21}$ his desire to return to the capital must have grown through those years, and when the opportunity arose to tackle a new job in London Hannay did not hesitate to seize it. 


\section{Chapter $V$ : London: Decline, 1865-1868}

On 7 February 1865, after much preparation and a good deal of advance publicity in the press, there appeared in London the first number of a new evening newspaper, the Pall Mall Gazette. It was obviously different from its competitors in a number of ways. Physically, it did not present the appearance of hideous clutter which makes mid-nineteenth century newspapers such an eye-straining agony to read. It was printed in large type on a double-columned, wide-margined page somewhat smaller than that of the modern tabloid. Even the heavy, slightly tinted paper on which it was printed was unusual. As to the contents of the Pall Mall Gazette, these too did not conform to what the Londoner of 1865 expected to find in his daily newspaper. There was the evening's news, to be sure, though in condensed form, as well as excerpts from the morning papers. But the emphasis was on commentary and reflection. Each number contained, in addition to a thoughtful and felicitously written leading article, several brief essays on aspects of the contemporary scene such as one would expect to find in a monthly or quarterly review. Hence the Pall Mall Gazettc's subtitle, the Evening Review.

The Pall Mall had been conceived by an old friend of Hannay's from Illustrated Times days, Frederick Greenwood, and the venture was financed by George Smith, of Smith, Elder \& Co., who enthusiastically supported Greenwood's vision of a paper written in flawless English, not inflated journalese, by the best available men (and women) which would "bring into Daily Journalism that full measure of thought and culture which is now found only in a few Reviews."1 Writing in 1897, Greenwood recalled the dual inspiration of his project: he had hoped to capture in the Pall Mall the wit and "all that was quaintly graceful in the old-fashioned form" of the AntiJacobin; "get a copy of that famous sheet, with another of the 1864 or 1865 Saturday Review, put them together, turn their pages over, and you will recapture the idea for the original Pall Mall."'2 George Smith, who had been Thackeray's publisher and friend, and the late novelist's daughter Anne were responsible for the name of the new journal (in Pendennis, the Pall Mall Gazette is a paper "written by gentlemen for gentlemen"): it was Smith also who persuaded the reluctant Greenwood to serve as editor. 
Disillusioned as he was with Edinburgh, Hannay must have responded with alacrity to Greenwood's invitation to join his staff. ${ }^{3}$ On the Pall Mall Gazette, instead of waging single combat against Blackies, Beggs, and Russels, he would be joining forces with some of the most remarkable talents of the day: Greenwood's list of his early contributors includes, among others, Anthony Trollope, Fitzjames and Leslie Stephen, G. H. Lewes, R. H. Hutton, Charles Lever, J. A. Symonds, E. S. Dallas, George Eliot, Anne Thackeray, and Theodore Martin. And no writer could have wished for a better editor than Greenwood: while respecting the peculiar virtues of all his contributors and retaining their confidence and affection, he knew how to get out of each the best that was in him. ${ }^{4}$ Though his high-minded approach to newspaper editing did not bring about quick commercial success, the Pall Mall soon achieved a reputation and influence commensurate with the intelligence and skill displayed in its columns. In the Babel of mid-Victorian journalism, it spoke with a clear, distinctive voice. ${ }^{5}$

Nevertheless, the reality of working on the Pall Mall Gazette. even under these conditions, must have fallen short of Hannay's expectations. He was no longer the editor-in-chief, the man who determines the policy and the very tone of a paper. His personality, which had made itself felt so strongly in the Edinburgh Courant, was now subordinated, not so much to Greenwood's as to the peculiar collective personality which, like many significant newspapers and magazines, the Pall Mall Gazette assumed. Almost everything in the Pall Mall was unsigned; very little in it can be identified on the basis of internal evidence as definitely Hannay's. ${ }^{6}$

Leader-writing, Hannay's great strength and joy in the Courant days, was very largely in the hands of Greenwood and Fitzjames Stephen on the Pall Mall, and their leaders were quite different from the sort Hannay had turned out with such zest in Edinburgh. Cautious and independent where the Courant had been positive and partisan, the organ of no political persuasion, the Pall Mall Gazette was able to view men and movements in the round, with objectivity and detachment. It could see both the good and the bad in Palmerston and Derby, Gladstone and Disraeli. The last-named, though he was ultimately to become as much of a hero to Greenwood as he was to Hannay, was subjected to some particularly rough 
handling during the Pall Mall's early years; Hannay must have winced to see a speech by Disraeli dismissed in a Pall Mall Gazette editorial as "entertaining, but insincere; amusing, but impudent; clever, but with the unfortunate cleverness of a farceur who uses his talents for malign purposes" (30 October 1867, p. 1).

On the outstanding political question of the mid-1860's, parliamentary reform, the Pall Mall's position also differed painfully from that of the Edinburgh Courant. Whereas Hannay had firmly opposed democracy and any further extension of the franchise as a matter of principle, the Pall Mall was much calmer and more pragmatic in its leaders. Reform was inevitable. Democracy was bad only if it resulted in an overturn of the country's cherished institutions, which was most unlikely to come about under any conceivable scheme of reform.

The Pall Mall's approach to Gladstone's abortive 1866 reform bill was particularly characteristic. Instead of arguing its position with rhetorical flourishes, it tock time to make up its mind and ultimately showed with the aid of numerous statistical tables that the measure would give the working class control of the constituencies of large towns and cities. This would be unfortunate, according to the Pall Mall, not because the working class ought not to wield this kind of power, but rather because the framers of the bill had clearly not expected such a result to follow its adoption; moreover, they had not taken the trouble to distinguish between constituencies in which the working class could be trusted to exercise power responsibly and those in which it could not. There are subtleties and nuances in its leaders on this complicated question which are nowhere approached in the much more doctrinaire Courant. ${ }^{7}$

Though Hannay was a contributor to the Pall Mall Gazette until his death, there can be little doubt that he felt uneasy in a subordinate position on a newspaper whose editorial policy he did not support. ${ }^{8}$

A much greater cause for unhappiness overwhelmed Hannay the year he returned to London from Edinburgh. On 29 December 1865 his wife Margaret died after a short illness at the age of thirtytwo-"one of the saddest things I ever heard," as D. G. Rossetti wrote his sister Christina. ${ }^{9}$ Hannay himself a few months later referred to "the untimely loss of a beloved wife" as "the most 


\section{James Hannay}

dreadful pain inflicted on mortals by any weapon in the armoury of doom"; ${ }^{10}$ in his case, it was a pain from which he never fully recovered.

Its immediate result seems to have been a profound depression, accompanied by bouts of heavy drinking and an inability to work, of which he was able to cure himself only by fleeing London and its temptations for a time and taking lodgings at Southend, leaving his children in the care of an old family friend, Charlotte Cole, at his house at 31 Tavistock Place. In the peace and quiet of Southend in the winter, he managed to recover a good deal of his composure. Almost a year after Margaret's death, he wrote Miss Cole that he was working hard and, though lonely, considered himself much better off at the seaside than he would have been in London.

How should you like to Xmas it here? I confess, if I could avoid passing the anniversary-you understand-at 31-it would be a great blessing.-Of course, I am always thinking of her, here; but here, she was never anything but well and happy.

When I find how much work I get through in this place, I curse my folly in not having come long ago; and in having wasted money and time in such miserable ways this twelvemonth.

In a P.S., he added: "If you hear any suggestions of visits to me here, except from my own household,-please discourage them.-I want to be alone for every reason." 11

Even before this melancholy event and its consequences, something else must have preyed on Hannay's mind: the realization that, though he was writing energetically much of the time, he was turning out virtually nothing that lived up to the promise of his earlier work or went significantly beyond the books and essays he had written before going to Edinburgh. ${ }^{12}$

With the exception of the Studies on Thackeray (1869), Hannay published no book consisting entirely of new work after the mid1850's. The Essays from the "Quarterly Review" (1861), dedicated to Carlyle, collected his first nine contributions to that periodical. A Brief Memoir of the Late Mr. Thackeray (1864) was a sixpenny reprint in paper covers of his Edinburgh Courant obituary notice of his great friend-an essay which Trollope called "the only good attempt of its kind that I have seen." 13 Characters and Criticisms 
(1865) consisted largely of leaders, reviews, and obituaries (including, again, the one of Thackeray, which now appeared for the third time in two years) which Hannay had written for the Courant, but was filled out with his last Quarterly Review article (on Plutarch), numerous epigrams, and other pieces dating back as far as 1848 . $A$ Course of English Literature (1866) gathered up in one slim volume the series Hannay had written for the Welcome Guest in 1858-59. And Three Hundred Years of a Norman House (1866) was a long essay in Hannay's pet subject of genealogy with numerous digressions concerning his views on pedigree: a history of the origins of the Gurney family of Norfolk which he had begun and almost completed seven years earlier; perhaps because the whole manuscript came to less than 40,000 words, Hannay also included in that volume his Quarterly Review essay on "British Family Histories" and an 1865 Cornhill article on the Temple family.

Even in the Studies on Thackeray, published just after the appearance of the Library Edition of Thackeray's collected writings, Hannay returned to a subject with which he had often dealt before. Nevertheless, this modest book has a genuine interest and value. Undertaken when Thackeray's life work in its entirety lay open to scrutiny, long after the discretion to be used in writing of a living author or the reverence due to one recently dead had ceased to be obligatory, it is a significant assessment of a major literary figure by a critic who had enjoyed an intimate knowledge of both the man and his works for two decades. There is nothing else quite like it in the small library of Thackeray criticism which has accumulated over the past century: it remains a highly useful volume.

Much of the Studies, as one might expect, went over ground that Hannay had covered in his earlier commentaries on Thackeray. He once again paid tribute to the excellence of Thackeray's prose style, which had been largely formed, in Hannay's view, by Thackeray's affinities with Latin, French, and eighteenth century English writers. There was, too, the same insistence on the rare quality of Thackeray's realism, which was all the more faithful to "the great and permanent features of human nature" (p. 7) for his refusal to stoop to mere photography of surfaces. This realism was perhaps best illustrated in "the probable, reasonable, and entirely natural and sensible way" Thackeray managed the career of Becky 


\section{JAMES HANNAY}

Sharp. "Nobody can lay his finger on an incident in it not likely enough under the conditions, and in perfect keeping with Becky's own character, and that of the people among whom she is thrown" (pp. 20-21).

As he had done before, Hannay defended Thackeray against the charge that his view of mankind was hard and cynical. On the contrary, "it was the natural tendency of Thackeray to be more tender and sentimental than he shows himself," and "it was his intellectual honesty which kept this tendency in check, and made him lay bare all his severest thoughts about the ugly, and paltry, and ridiculous side of things" (p. 18). This most generous of men did not expose the follies and vices of his fellows in a spirit of malice. In his searching chapter on "Thackeray as a Humourist and Satirist," Hannay argues convincingly that Thackeray's largely unflattering representation of human nature grew out of a combination of causes: his "watchful and critical good sense," his "ludicrous perception," and "a certain softness and playffulness which in a weak man would have become sentimentalism" (p. 40). Above all, far from being unjust or cruel, his humor "was always moral and intellectual in the objects on which it employed itself-was always the humour of a thinker-and always suggests a tacit reference to the serious and sorrowful side of life, which gives an acid to its flavour piquant as that of the Attic olive" (p. 39). In this respect, his late friend was linked, in Hannay's view, with his other great Victorian idol. "One of the duties of a thinker in this age is to oppose a shallow optimism, which strikes at the root of all serious thought, and of Christianity itself; and with the exception of Carlyle, no man has perhaps been more useful in this direction than Thackeray" (p. 18).

Thackeray's social criticism, Hannay believed, had lost none of its relevance. In attacking snobs, Thackeray was not attempting to tear down class distinctions, which he regarded as essential, but rather the cruelty, insolence, and pretension to which class distinctions were likely to give rise. Snobbery is really nothing else than "social servility,-with the consequent insolence to 'inferiors' by which servility recoups itself, and endeavors to save its amour propre" (p. 51). It is to be found at all social levels, and it is a mark of Thackeray's great honesty that he was particularly unsparing in his attacks on his own middle class, which he regarded as "the 
stronghold of snobbism" (p. 53). Unlike the work of the ordinary casual or spiteful wag, Thackeray's satire was intended to be corrective rather than destructive: he wanted to improve the existing social system, not overthrow it.

As we have seen, Hannay never indulged in empty adulation of Thackeray, and his view of the older writer's shortcomings is no more clouded in the Studies than it had been in his earlier published assessments. Indeed, it is often more penetrating and, on one occasion, more pungently expressed. Thackeray's unjust treatment of Sterne, as a man and as a writer, in the English Humourists Hannay called "positively silly" and "almost vulgar" (p. 7l). Thackeray's distorted estimates both of Sterne and of Swift grew out of his inability to let the novelist in him remain subordinate to the critic: some, at least, of his remarks on both men can only be called fiction. And not necessarily good fiction: even in art, Hannay insisted, no character as full of violent and irreconcilable contrasts as Thackeray's Swift would be admissible. Hannay accounted for Thackeray's unwontedly harsh view of the Dean of St. Patrick's by his wish to atone for what he regarded as the excessive sarcasm of his own early satire. ${ }^{14}$

The Studies on Thackeray put forward no absurd claims for their subject. Hannay, as always, was willing to admit that Thackeray had his superiors-as Scott was his superior, for example, "in romance and historical feeling," in "imagination," in the richness of his "vein of poetry" (p. 11). Thackeray himself was too honest to attempt work which he knew he was not equipped to do: he "has not left us a Sancho Panza, Andrew Fairservice, Caleb Balderstone, or Jacob Faithful" because he was well aware that he could not "draw fancy pictures of classes with whom he had never lived" (p. 6). (It was also a mark of "the veracity which was his crowning merit" that Thackeray "saw that the old type of feudal servant had disappeared ... and that there was little poetry or humour to be got out of relations based upon mere money" [p. 6].)

Thackeray's great interest lay in his remarkable combination of powers-his completeness: what Hannay called his "unity of genius" (p. 3); always, in everything he wrote, the whole uniquely endowed man could be seen working. He was (as Hannay put it in his last published words on Thackeray) "a genius whose head 


\section{JAMES HANNAY}

and heart worked together; a wit whose wit did not spoil his reason; a novelist of solid reflection, as of imaginative power; a satirist whose earnestness was tempered by kindly feeling; a critic who looked at other men's work with the peculiar insight and power of judgment which belongs to those who can themselves create. For convenience' sake he has been looked upon under different aspects, but always with a recollection of his great and comprehensive unity. Having walked round the stately figure, and looked at it from various points of view, the critic takes off his hat to it reverently, and moves slowly, and somewhat mournfully, away" (pp. 106-07).

Hannay's periodical writing during the 1860's was cast in familiar molds. There were numerous contributions to some of the better serious magazines like the Cornhill, Temple Bar, and the North British Review, mostly dealing with naval matters, genealogy, and literary history, and all written in the lively, graceful, and (in the best sense of the word) popular style which came so easily to Hannay. Some of these essays were more personal and "familiar" than anything Hannay had yet done; though he was still generally in the habit of dressing up autobiographical materials in semi-fictional form, there is no mistaking the extent to which he drew on his own experiences: for example, in the Cornhill pieces on "A Scotchman in Holland," "Bohemians and Bohemianism," "Provincialism," and "The Scot at Home," or in the "Recollections of a Provincial Editor" ("Uchtred McGuffog" of the "Reekyborough Courier") in Temple Bar.

This periodical work is still readable and often quite entertaining, and it certainly teaches us a good deal about Hannay, but it represents no advance whatever over the sort of thing he had done as well ten years earlier, and much of it simply reworks ideas which he had already put before the public. More and more he was repeating himself: a Cornhill reader who came across Hannay's "Naval Men" in October 1866 might have dimly remembered his "Inner Life of a Man-of-War" from February 1863, which had made many of the same points; in this "Naval Men" we meet yet once more such stock Hannay characters, by now nearly two decades old, as Adair, Booing, Gunne, and Kraggles; Erasmus, the subject of a July 1865 Cornhill article, appears again to take a prominent role 
in "The Satirists of the Reformation" in that periodical in November 1867; and so on.

As for Hannay's political and philosophical views, though the Pall Mall Gazette furnished him no adequate outlet, he was certainly able to express them in a new short-lived Conservative weekly, the Imperial Review, to which he contributed a series of fifteen papers on "Cads" in 1868.15 Like the "Sketches of Radicals" in the Press fifteen years earlier, these owed something of their flavor to Thackeray's Book of Snobs but really resembled more closely Hannay's own characteristic kind of slashing political satire.

A Cad, quite simply, was a man who-from ambition, ignorance, boorishness, spite, or some other unworthy motive-wished to subvert existing values and institutions. This did not necessarily mean that he was a professing Radical, though almost all Radicals were Cads; for reasons of his own, he might choose to ally himself with the Whigs or even the Conservatives. It was a deplorable fact that Cads were increasingly coming to be found in the hitherto honorable and learned professions, for whose traditions, however, they cared nothing. The Literary Cad, for example, was devoid of the classical learning which used to be a necessary part of the equipment of the man of letters; he had nothing of "the old love of knowledge for its own sake, the old care for writing as an art" (IV [17 October 1868], 365). Cads were coming to the fore in medicine, law, the army and navy-even in the clergy: "the pure typical old English parson, a well-born gentleman, and sound classical scholar is unquestionably becoming comparatively rare" and the Clerical Cad "is glad of this, and fires many a shot at him in his retreat. He reviles him as a fogy, and as a Tory; describes his honorable affection for good port as 'wine-bibbing;' and derides his Greek as pedantry" (III [16 May 1868], 456).

The alarming ascendancy of Caddism was both a cause and a result (one wishes Hannay had been more explicit) of the onrush of democracy and the general leveling and obliteration of values in nineteenth century England. But this was a complex process, socially as well as politically. The lower class itself was not a hotbed of Caddism: that was a slander originated by the Cads themselves. In truth, "the peasant, the fisherman, the soldier, the porter, and so forth, far from being Cads, are much more like gentlemen than 


\section{James Hannay}

the Cad proper. Their manners are natural; their instincts loyal; and they are friendly to the social system, and institutions generally, of the country. The true Cad is a man who has risen far above these good people, and aspires to an equality with gentlemen, but who carries into his new sphere the characteristic faults of the meaner souls of humble life" (III [21 March 1868], 272). Nor was even the aristocracy free of this undesirable type: Cads were continually invading its ranks by marriage, by the purchase of old estates, by assuming historic names and forging long pedigrees. The Cad made a good deal of noise about his contempt for the nobility, but at bottom he was generally as much of a toady and a tuft-hunter as the keenest snob; indeed, there was much in common between the Cad and the snob. Though it was possible for a snob to be a gentleman, however, a gentleman was the one thing a Cad could never be: "a Cad has the kind of faults which a man is liable to as the consequence of not being a gentleman, and that is the essence of him" (III [21 March 1868], 272). There were, to be sure, Genteel Cads, but theirs was a superficial sort of polish and not the genuine, deep-seated gentility of tradition and breeding.

All this, of course, was doctrine which Hannay had expounded often before in print. It was no less effective in the Imperial Review than it had been earlier, and he used the device of the character with telling results in limning the various species and subspecies of Cads. It might repay the prolonged study that would be required to assess the extensiveness of the personal allusions in these papers: for example, a frequently mentioned Literary Cad, Aniseed Potts of the Mausoleum, is obviously Hepworth Dixon of the Athenaeum, ${ }^{16}$ and one cannot escape the conclusion that Hannay was once again attacking Dickens in the character of Pooter, another Cad of this class. "Pooter's novels-infinitely clever, but not one of them a work of pure art, the comedy being always grotesque, and the pathos maudlin-have spoiled the popular every-day style of our whole generation." He is a "Radical philanthropist" who, most unphilanthropically, "turned his wife out of doors" (IV [17 October 1868], 365). ${ }^{17}$

Though the years after Hannay's return from Edinburgh and Margaret's death can hardly be called barren, his work during this 
period was disappointing. He wrote less than during any previous comparable length of time, and, as I have tried to show, he tended increasingly to plagiarize from himself. An author who does not perpetually move on to fresh material, fresh points of view, fresh techniques does not merely stand still: he grows stale and, really, retrogresses, and this was Hannay's case in the years 1865-68.

Hannay's friends-men like Espinasse and Jeaffreson-noticed a concomitant change in his behavior and appearance: frustration in Edinburgh, the death of his wife, financial insecurity, drink, family obligations-these and other sources of worry and disappointment weighed heavily on him, and visibly shook and aged him. ${ }^{18}$ Nevertheless, his innate wit and sociability, and above all his love of good talk, did not desert him: the novelist Annie Thomas, who had not known him before, was greatly impressed by the charity and good humor which he displayed even in his time of affliction.

His cordial sympathy was as cheering and invigorating as sunshine, and the way he came out from his own stronghold of trouble to try and clear away the trouble of another, spoke eloquently for his heart... He talked admirably, because it was not in him to talk in any other way, and not because he desired to dazzle by a display of erudition and facility of utterance. He always talked well-to a child, who could only respond to the flow of words with a gaze of baby-wonderment-to a woman whom he half admired and half loved for being as he said "so jolly ignorant." He did it because it was not in him to express himself in any other way. It was natural that the rich harmonious ideas with which he was fraught should put on the garment of rich harmonious language. And so his conversation pleased everyone, even those whom it extinguished. ${ }^{19}$ 


\section{Chapter VI: Barcelona: Exile, 1868-1873}

It seems to us now-and it may well have seemed to Hannay in the mid-1860's-that his life had to take some sort of new direction if the talent and energy that remained to him were not to be utterly dissipated. Such a change did, in fact, occur in the summer of 1868 when, through the good offices of his old benefactor Lord Stanley, then Foreign Secretary, Hannay secured an appointment as British consul in Barcelona. ${ }^{1}$ Whatever the drawbacks of a foreign station might have been, the post carried with it an assured annual income of $£ 600$, as well as an expense allowance of $£ 200$ a year, and to Hannay, plagued by debt and faced with the responsibility of raising a large family, this must have been an irresistible inducement.

Before moving his household to Spain, Hannay took another important step: he married again. His second wife was Jean Hannay, the daughter of a kinsman whom he had known and respected for years, George Hannay of Kingsmuir (near Pittenweem, on the Firth of Forth). As he wrote to his daughter Elizabeth in announcing his intention: "She is an old friend of mine; and was a dear friend of your mother's: she is, moreover, of the chief or main branch of our family,-a thorough gentlewoman, as well as one of the kindest, most amiable, and most sensible ladies I ever knew.-I trust that you will all be prepared to receive her with the highest respect \& affection; and will so help me to regain the happiness which I once knew during your dear mamma's life-time."2

From what little it is possible to discover of the second Mrs. Hannay, she seems to have been a perspicacious as well as an estimable lady. A letter written to a relation in London thirteen years before her marriage survives and indicates something of her turn of mind and her family's attitude toward her future husband.

We are all engaged with "Eustace Conyers". I have as yet read only the first and second volumes and I fear I must acknowledge them too clever for me. I do not think our friend Mr. James is sufficiently impressed with the importance of securing the good opinions of young lady readers, who can enjoy a genuine love story without being able to philosophise on the subject. And then what he himself designs as his harmless and dilettante taste for genealogical enquiries shines so conspicuous throughout that one never loses sight of the author of this book. Politicians, genealogists and sailors he appears to me to hold in especial rever- 


\section{BARGelona: Exile, 1868-1873}

ence, and I should fancy that these parties will read with a keen relish "Eustace Conyers."

Of one thing, however, I am sure; that the author cannot retain more friendly or warmer recollections of Kingsmuir than the family there entertain for him. And his kindness in dedicating the book to my Father while it pleased and flattered him, was greatly appreciated by us all. ${ }^{3}$

Almost immediately after the marriage, which took place at Crail, the Hannays left Scotland on 12 August and made their leisurely way south, via London, Calais, Paris, Bordeaux, Bayonne, Irun, Pamplona, and Saragossa. ${ }^{4}$ They arrived in Barcelona on the 27th, and Hannay took charge of the consulate the next day. ${ }^{5}$

No sooner had he settled into his new post than Spain was shaken by the September revolution of 1868 , which resulted in the exile of Isabella II and the regency of General Francisco Serrano. During Hannay's four and a half years in Barcelona, the country never experienced anything like stable government, even after Prince Amadeo of Italy was induced to accept the crown in 1870, with intrigue, repression, inefficiency, and venality to be seen on all sides.

It was one of Hannay's duties as consul to report to the Foreign Office and to the British minister in Madrid on the events of the revolution and its aftermath as they looked from Barcelona, but he was not supposed to be exclusively, or even primarily, a political observer. Writing (anonymously, of course) about "The Consular Service" in the Cornhill in November 1870, he gave some indication of the arduousness of his office and the versatility he was required to display as consul.

It soon dawns upon the new H. B. M. C. that he is a political, commercial, and even literary agent of his government; and a magistrate, notary, registrar, post-master, and shipping-master, into the bargain. For, while the principal object of his appointment, says the Foreign Office, is "for the protection and for the promotion of the commercial interests of her Majesty's subjects," he "must perform any service, and be prepared to furnish any information that may be required." Again, "consular officers must keep the Secretary of State and her Majesty's Minister at the Court of the Country in which they reside, regularly and fully informed of all occurrences of interest, whether political or commercial."B

Though most of his routine work had to do with the comings and goings of British vessels in Barcelona harbor, he was also called on 
to deal with all sorts of delicate situations involving British subjects.

The relations of a British consul to his countrymen at large are indefinite and extensive. At his port he is expected to give advice and assistance about everything that may arise, even a quarrel between a Briton and his wife, one of many subjects where he has no "instructions" to guide him. If there is a chaplaincy assisted by government, it is under his direction; if the church be a voluntary one [as was the case in Barcelona in Hannay's time], he must be still a churchwarden, or a committeeman, or something in it. . . He grants passports. He marries happy couples, under a warrant from the Secretary of State . . . and gallantly "stands" wine and cake on the festal occasion. Should a tourist of his country die at a hotel, he takes care of his property, conducts his funeral, and hunts out his next of kin. ... A youthful female with a baby requests a private interview. She wears a pork-pie hat, and is in tears. She has been brought from England by Monsieur, or Don somebody, who has abandoned her,-and, of course, she is in need of money and does not speak the language. H. B. M. C. interests himself in the case of the penitent female. He finds out the whereabouts of the villain, and writes a private line to his colleague in that part of the country, who, discovering that the villain has a wife of whom he is afraid, judiciously uses the knowledge to make him do something for the poor little idiot. A subscription is also raised, which the consul heads, and she is sent back to her own land,-let us hope, to sin no more. The next visitor is a T. G., a traveling Irish gentleman, one of the O'Brallaghans of O'Brallaghan Castle. Oddly enough, his remittances have not arrived, though his brother Jack, whose letter he produces, promises to send by next post. Oddly enough, also, the landlord of the hotel-whose knowledge of Irish genealogies is limited-has never heard of the O'Brallaghans and is pursuing this scion of his race about his bill. But if the consul . . would just write a line intimating that after seeing his visitor and his papers, he believes him to be what he declares himself-the landlord will be patient for the present.... As for the correspondence addressed by people to the consulates on their own private business, it is endless. One of the most deeply-rooted convictions of many British traders is, that consuls are appointed to do for them what they ought to pay an agent for doing. They send out prospectuses of guttapercha furniture, and machines for docking horses' tails; inquire after the solvency of local firms; and consult the consul as to whether the population of his district prefer dolls with blue eyes or with black. To his half-a-dozen other functions is thus added the function of a bagman; and it being the fashion to toady these kind of people just now, the consul who commits their letters to the waste- 
paper basket is liable to be snubbed, in a style in which few gentlemen would snub their footman. ${ }^{7}$

The consulship, at least in Hannay's view, was no sinecure; and the compensations afforded by life in the south were few: the abundance of Roman remains to study, the climate (when it was not unbearably hot), and the excellent, cheap local wines were the only ones which Hannay mentioned with any frequency in his published writings, and of course there was also Mediterranean bathing and boating with his boys and an occasional trip to the theater or the shops with his daughters.

Certainly in most respects he did not find life in Spain enjoyable, though it did exert a certain fascination. In his view, the Spanish were, to put it mildly, "a backward people": 8 after a series of revolts and successive new constitutions, the country was still "scarcely more fit for self-government, in our British sense, than the Zoological Gardens."9 Despite an educational system that looked impressive on paper, the level of general culture and even of mere literacy was appallingly low; despite the Spaniard's boasting of the national hidalguia and caballerosidad, "the more prosaic virtues of common honesty, industry, punctuality and cleanliness attract but little laudation,"10 and behind the public façade of courtly behavior people dealt crudely and even cruelly with each other. The country had too long been dominated by a singularly narrow-minded clergy and, particularly in recent years, by generals with political ambitions; the aristocracy was numerically large but lacking in public spirit and intellectual distinction. "What is wanted by Spain is a purer civil government; a higher standard of education; and a development of industrial and commercial life." 11

The Spanish took great delight in blaming all their troubles on the government, but in fact-with no class able to govern honestly and capably-the country had exactly the sort of corrupt, inefficient government it deserved, one that mirrored all the characteristic shortcomings of private citizens. For an Englishman, it was always vexing to do business with a Spanish official.

Questions are hung up for weeks, or never answered at all. Documents submitted in support of applications are lost-a fate, by the way, which often happens to passports deposited with the authorities pursuant to 
orders. Invitations to public ceremonies reach the invited person an hour before the ceremony begins. You are never sure of finding a functionary at his post. Sometimes he is out, or, está comiendo, he is eating; or you get a glimpse of him in his shirt-sleeves smoking a cigarette. Probably there will be a towel hanging out to dry from one of the front windows of a captain-general's palace; and the quarters of such a potentate, with their cracked roof, tawdry gilding gone to decay, dirty floors, and loafers in uniform spitting about, are less respectable than those of a minor pasha in Syria or the Levant. This queer, shiftless fashion of living and working, a sort of official "hugger-mugger," which a man must be in practical contact with to appreciate it, contrasts strikingly with the pompous, high-flying tone of the correspondence which emerges from amidst the dingy finery of such abodes of power. Our own official style is ludicrous enough, and would seem to suggest that the younger clerks are set to practice upon her Majesty's officers abroad. But the Spanish red-tape style rolls out like ribbons from the mouth of a conjuror. The adjectives walk three abreast. When a Consul finds himself addressed as Vuestra Señoria, your Lordship, and his "elevated penetration" is appealed to, in the matter of the theft of a couple of buckets from the brig Sally, he may be excused for grinning at the flattering despatch.12

But all this was really more frustrating than amusing. Near the beginning of his first Cornhill article on Spain, Hannay confessed "that, though living in Spain all the year round, I find it exceedingly difficult to understand her and her life at all."13 Though he undoubtedly came to know Spain better in the next few years, there is little evidence that he ever felt more comfortable there.

Barcelona itself was a hybrid and rather repellent puzzle: undeniably Spanish, but strongly marked by French influence and an ineradicable Catalan character. Its people struck Hannay as unattractive physically and socially: clannish and inhospitable, commercially minded, fond of empty and brucal amusements. Intellectual life languished, "and education is an affair of empty pretence. In this former Roman colony, this former seat of a court, with its bishopric and university, I should not know where to go if I wanted to buy a Horace, or the very commonest English book."14 In comparison with Barcelona, even nineteenth century Edinburgh seemed an Athens; in comparison with even the humblest English town, Barcelona was in many respects incredibly primitive. "The barber-surgeon still bleeds; the patient, dissatisfied with his doctor, 


\section{BARCELONA: EXILE, 1868-1873}

sends for a witch; the dead poor are buried like dogs. The beautiful blue water of the port is poisoned from execrable drainage." 15

In his letters home, Hannay often wrote of his tour of duty as an "exile,"16 and he was clearly speaking personally when, in the Cornhill article mentioned earlier, he referred to the consular service as

hardly more than exile, plus bread-and-butter. And exile is exile. It is not holiday rambling from city to city, where the tourist sees nothing but the poetry and the surface-picturesque of strange lands. Let such a one try living and working, with his eyes necessarily on the seamy side of the life which seems so refreshing to him (as, indeed, it is so seen) after London and the cloudy North. He will soon find that you may be bored as much among palm-trees and orange-trees as anywhere else; that grapes at a penny a pound don't make up for the want of all intellectual sympathy and jolly conversation; and that our old friend, Atra Cura, sits behind the rider as punctually on a camel or a barb as on a British livery-stable hack. The consul at a good port in Europe certainly does come across agreeable and cultivated people at intervals. The navy, with which the consulates have close relations, is a great resource,-though men-of-war differ in type, like human beings. But the agreeable people move off somewhere else just as H. B. M. C. is getting intimate with them. H. M. S. Lotus sails away to the admiral,--her hearty captain being succeeded by a feeble prig. And though one yacht may bring a pleasant swell, with a sound taste in the matter of burgundy, another may be the home of some rich old noodle who has eaten himself into a state of idiotcy [sic], who is under the charge of a doctor, and who snorts and makes strange noises at meals. ${ }^{17}$

Hannay can scarcely have derived much satisfaction from the job he had gone into exile to do. As his published writing about Spain indicates very clearly, he was as alert to the nuances of life in that troubled country as any Foreign Secretary could have wished a consul to be, and he was capable of extraordinary devotion to duty, as he showed during a violent outbreak of yellow fever in Barcelona in 1870 , when he remained at his post, performing the many services which that crisis rendered more important than ever, in spite of all sorts of urgent advice to keep clear of the infested city. By and large, however, he seems to have done his job erratically; and the Foreign Office and consular records for that period show that more than once he came close to losing his position. ${ }^{18}$ 


\section{JAMES HANNAY}

As early as October 1868 he was being mildly rebuked for not following regulation procedure in numbering his dispatches and drawing his bills. But these were minor infractions. More serious trouble came in 1870 when he first incurred official displeasure for ignoring letters from London and, even worse, for failing to keep the minister in Madrid, Austen Henry Layard, informed of developments in Catalonia. To these reprimands Hannay responded as best he could: mail often miscarried in a primitive country in upheaval; he reported to Madrid whenever, in his judgment, there was anything to report; at all events, he would endeavor to do better in future. But the complaints from Whitehall continued to come, and after some particularly painful exchanges in the spring of 1872 , Hannay was warned that in case of any further neglect of his duties the Foreign Secretary (now Earl Granville) would be obliged to recommend to the Queen that Hannay's commission be canceled. When Granville sounded out Layard on the matter, the minister replied that, in his view, the case against Hannay ought to be dropped: according to "accounts which I have received privately concerning him" he had "got into habits which rarely admit amendment" and he had not, indeed, been very useful to Layard, but he had improved noticeably since the latest reprimand. (There was, in fact, a sharp increase in the number and length of Hannay's dispatches to London and Madrid during the summer of 1872.)

It did not help matters that Hannay's superiors were in a position to make life difficult for him. In June 1870, for example, his urgent request for a two months' leave of absence at a time of acute domestic affliction was summarily denied on the grounds that his conduct had not rendered him deserving of any such privilege. Nearly two years later, after Hannay's vice-consul had been promoted to a consulship in Corunna, Hannay wrote Earl Granville to ask that, in view of the volume of work transacted by his office, the Barcelona vice-consulship not be permitted to lapse, and suggested his eldest son David as the person best qualified to assist him in that post. On Wylde's recommendation, the Foreign Secretary denied this request too: Hannay had been remiss in carrying out his duties, and therefore no favors should be extended to him.

As the previous paragraphs will have suggested, domestic and financial cares weighed on Hannay at least as heavily in Barcelona 
as they had during the last years in London. On 7 May 1870 Jean died after an illness of several months, leaving him once again a widower with a large family (including now another daughter, born in Barcelona the previous year). The children had to be cared for and educated; indeed, David and Patrick had already been sent back to Scotland at considerable cost for a part of their schooling. Hannay complained of these and other heavy expenses in a letter of 3 May 1872 to Earl Granville in which he attempted, rather lamely, to explain his failure to pay his vice-consul all of the salary that was due him. Another, particularly pathetic, indication of Hannay's financial state appears even earlier in his correspondence with the Foreign Secretary. On 8 October 1870 he wrote Earl Granville that he had ordered a shield of the royal arms painted and hung over his office door to identify the British consulate in the same prominent and dignified manner as every other consulate in Barcelona. Could he be repaid the $£ 5$ he was out of pocket for having this work done? He would not make such an application, he said, were it not that the demands on his office allowance were so heavy and that the cost of living in Barcelona, and his other obligations, more than exhausted his salary. His diary, which he began keeping again in July 1872, shows clearly how hopelessly he had got himself into debt by that time: each sum, however small, which he earned by his writing was immediately used to make a payment on one of the loans he had taken out, and he kept borrowing more money all the time. Finally, though there were periods of abstinence, Hannay's alcoholism got no better and, of course, only complicated his other problems.

Whatever Hannay's writing may have done to keep him and his family from financial ruin, it certainly constituted one of his few remaining links with the English literary life which he had left behind him in 1868. He continued to contribute to the Cornhill, as we have seen; all but two of the ten articles he sent to this periodical from Barcelona dealt, most revealingly, with Spain, past and present. Encouraged by the kindness and understanding of Frederick Greenwood, ${ }^{21}$ he also carried on his association with the Pall Mall Gazette, submitting occasional reviews, but again drawing heavily on his Spanish experience for his most important articles, the letters from "An Englishman in Spain," more than three dozen 


\section{James Hannay}

of which were published between October 1868 and November 1872. Written with all his old vigor, they provide much the same sort of indictment of Spanish institutions, manners, and morals as the Cornhill essays, but they have the additional attraction of furnishing a running account of the many vicissitudes of the Spanish revolution, the elaborate and confused political maneuvering following the flight of Isabella, the complicated wrangling about the choice of her successor, and the violent threats against the new regime from republicans on the left and Carlists on the right. These letters once more reveal Hannay not only as a shrewd and perceptive observer but also as a writer with a real sense of history; they are admirable journalism, and even after the lapse of almost a century they convey something of the suspense and excitement which they must have aroused in his contemporaries.

As reportage, they are equally effective when Hannay attempts a set piece of description or when he narrates some characteristically turbulent bit of action. For example, a Christmas turkey fair is described as follows:

Fancy a promenade lined with trees for the best part of a mile, the trees still covered with brown leaves, in the dead of winter, a sun shining which would do for an English June, and shining on stalls where flower-girls are selling fresh roses and violets and camellias, an orange tree glittering with its lamp-like fruit standing here and there in a flower-pot, beside them. A long way down this promenade, and close together, are the country folk in coloured handkerchiefs, with their turkeys for sale, varied by geese, and other poultry; pavo, however, being still predominant. The chaffering, the cries, the gabble of men, women, and poultry; the rustic dandies in purple caps and velvet breeches, the town snobs in imitation Parisian splendour and shiny boots; the eternal tobacco smoke, pierced occasionally by deadly whiffs of garlic; the portly priests in big black hats, and the dark-eyed lasses in light veils-all together make one forget everything but the present moment and scene, with its Southern mixture of gaiety, greediness, colour, barbarism, beauty, and dirt (5 January 1869 , p. 9).

His account of the inept, week-long attempt of the authorities to smash some crude barricades erected in the Barcelona suburb of Gracia by a band of radicals protesting conscription clearly renders the comic opera flavor of this episode: 
If the French had been coming there could not have been more showy preparations. ... On Tuesday, at daylight, the cannonade opened, and the boom awakened the whole city. One battery was planted in front of the barricade which guarded the main street of Gracia; another, to the right of it, in front of some open ground to the eastward, to command another barricade at the end of another street. Both were at the comfortable distance of six hundred yards. They fired all day; they fired a thousand shot; they cut in two trees which had not been used by the insurgents for their barricades; they knocked the head off a lamp-post; they hit private and innocent houses lying out of the range of fire; they knocked the poor village about in many parts; but they did not destroy the barricades, nor kill a single fighting man, nor lose a single man of their own (14 April 1870, p. 7)..22

Though the concepts and terms which Hannay had always applied to British institutions were usually not relevant to Spain (a country which, he felt, was not yet a genuine part of European civilization), his aralysis of that nation's troubles in the Pall Mall Gazette was consistent with his earlier political thinking-and no less sensible for that. Spain existed in a political vacuum. There was no effective monarchy or aristocracy; the middle class, which held most of the real power, was incompetent and corrupt; the working class, just stirring into political consciousness, was even less reliable. The clergy offered little constructive political guidance; the priests were "the laziest sons of the village boors ... who prefer the tonsure to the plough-tail because it is an easier life; who get a smattering of bad Latin and stale theology at the seminarios, knowing Greek not even by sight, and French itself not at all; whose ignorant spite against the Reformed Churches is venomous in the last degree, and whose morals a foreigner may well be excused for distrusting, since they are disturbed by their own countrymen" (20 August 1869, p. 11). Society was fragmented.

The noble is utterly out of sympathy with all other divisions of life. To him the canalla is on a level with the lower animals. The priest cares more for his Church than for his country. The merchant says the politicians are a gang of robbers, who interfere with the natural progress of the country to wealth and peace. The employer of labour denounces the labouring classes as revolutionary, and asks you, as I was asked by a rich man the other day, why England does not put down the trade unions? 


\section{JaMes Hannay}

The working man-and his natural brains are good-declares that his employer is a tyrant who has no kindness for him and who despises him. It will take generations of order and education and influence from higher races to knead these discordant masses into a compact whole (24 May 1872, p. 10).

Most disappointing to Hannay was the aristocracy, which behaved contemptibly during the Carlist uprising of 1872, letting their hired ruffians do all their dirty work for them. "When the Scotch lords rose against the House of Hanover in 1745 they did not send their vassals forward and stay at home themselves. They were always in the front. They behaved like gentlemen in the field, and they behaved like gentlemen on the scaffold. But the Dons (about the antiquity of whose pedigrees, by the way, there is ludicrous exaggeration prevalent in England) adopt an opposite course. They think campaigning ugly work, and prefer smoking puros, gambling, and making love to their neighbours' wives" (24 May 1872, p. 10).

Putting an irreproachable Italian prince like Amadeo on the throne, Hannay predicted accurately, would solve nothing: this "is only a prolongation of the Interinidad in a new form and under a polite disguise. It is the Interinidad with a nice new crown on, and with its shaky pins gracefully covered with royal robes" (30 November 1870, p. 11). It meant no relief for the chronic afflictions of post-revolutionary Spain: the "factious fighting... inspired by nothing nobler than spite, vanity, or greed;" "a favouritism as thorough as any in the Queen's time; a total indifference to public works; and a general angry shaking of empty heads over an empty exchequer" (29 November 1871, p. 10).

As the election of 1872 clearly showed, democracy was as great a danger to Spain as to every other society which Hannay had studied. The best men either did not run for office at all or were defeated, and flagrant dishonesty everywhere marked the campaigning and the voting. "Spain is of the same utility to the student of politics that a hospital is to the student of medicine, and at present the nature and action of universal suffrage may be observed here to good purpose" (6 September 1872, p. 9). And if the working class turned ever uglier in its mood and more dangerous in its aspirations, the men who made the revolution of 1868 had no one to blame but themselves. "The Spanish Internacional is a Frankenstein created 
by the Spanish revolution. Do revolutionists suppose that they may destroy just as much as suits themselves? that the smell of their flesh-pots, when they drink confusion to bishops and Bourbons, will not sharpen the appetite of the poor devil who strolls home hungry, as he passes their gates?" (28 October 1871, p. 4)

In view of the sad circumstances of the last years of Hannay's life, it would be uncharitable to find fault with him for producing nothing more memorable than these articles during his time in Spain. Indeed, it is to be wondered that this disappointed and careworn man was able to write with such insight and skill literally to the end, that even in extreme adversity he retained the intellectual vigor which had marked his work from the first.

Several days after he was found dead at the desk on which lay the corrected proofs of his article on Captain Marryat, the obituary writers had their say about James Hannay, as we have seen. But perhaps none of them wrote what needed to be written as aptly as a younger James Hannay had described the fate of a brother author twenty years earlier. Though the subject of these lines is Edgar Allan Poe, they might have served, without much alteration, as an epitaph for James Hannay himself:

The conditions of a man's life, complex as they are, make the real understanding of his life very difficult. Too often-particularly in artificial ages like ours-a man's whole career has to be run-like a race at a fair-in a sack! Many a man never gets fair play-sometimes is born with a constitution that won't permit it-sometimes is born into circumstances that will not. Let us be charitable. Southey's "Doctor," when he heard of a "toper," was wont to say compassionately, "Bibulous clay, sir-bibulous clay!" I would not put forward this compendious excuse for Poe, but we must allow for infirmity in the man. He was indulged early,-he was seduced by example. Because he left traces of something high and beautiful in him in spite of this, don't let us make that a reason for being harsher on him than on the frail mortals of his race. ... I learn from those who knew him ... that his friends loved him, and that those who understood him pardoned his infirmities ( $P, \mathrm{pp}$. xxiv-xxv). 


\section{Notes}

I

1. Sir Bernard Burke, a friend of James Hannay (who undoubtedly furnished the genealogist with much information about his ancestry), implied that they might have come to Galloway as early as the ninth century. A Genealogical and Heraldic Dictionary of the Landed Gentry of Great Britain and Ireland, fourth edition (London, 1863), p. 646 .

2. Dumfries and Galloway Courier (22 November 1864), p. 4; cf. William McDowall, History of Dumfries (Edinburgh, 1867), pp. 793-95 and 866.

3. "Sheerness Revisited," National Magazine, I (1857), 150.

4. "Aboard the Training Ship," All the Year Round, I (8 October 1859), 558.

5. "Sheerness Revisited," p. 150.

6. This is one of many passages in Hannay which are ignored by those who accuse him of a blind and snobbish worship of pedigree and disdain for the baseborn.

7. Something which continued to worry Hannay in later life. See his "Ships and Crews," All the Year Round, I (20 August 1859), 389-94.

8. See the reports of ship movements in the United Service Journal: May 1840, pp. 113 and 116; June 1840, p. 260; July 1840, pp. 407-08; August 1840, p. 552.

9. United Service Journal, May 1840, p. 116, and August 1840, p. 552.

10. United Service Journal, August 1840, p. 552, and September 1840, p. 113.

11. "Portsmouth," All the Year Round, I (24 September 1859), 518.

12. Both Percival Plug and Eustace Conyers participate in the suppression of the slave trade off the African coast. Since I can find no mention of such duty in Hannay's diary or other writings about his years in the Navy, I am assuming that these passages in $A$ Claret-Cup and Eustace Conyers have no autobiographical basis.

13. "Ships and Crews," p. 391.

14. "Mr. Adair's Narrative," United Service Magazine, June 1854, p. 209.

15. "Mr. Snigsby's Yacht," United Service Magazine, September 1851, p. 89. Cf. Singleton Fontenoy, II, 246 ff., for an excellent account of a rowdy night "on the town" in Valletta.

16. MS letter of 23 July 1844.

17. “Mr. Snigsby's Yacht," United Service Magazine, November 1851, p. 408.

18. Ibid., p. 408.

19. Public Record Office: Ships' Muster Books, Adm. 38/374-78.

20. On 24 November he wrote to his father: "I parted on the best of terms with Capt. Barnard and everybody-and am very happy where I am" (MS letter).

21. See especially Singleton Fontenoy, I, 315, and his review of Symonds' Mernoirs in the Athenaeum, 23 January 1858, pp. 105-07.

22. "The Court-Martial," United Service Magazine, September 1853, p. 45.

23. "Military and Naval Cads," Imperial Review, III (13 June 1862), 552.

24. Public Record Office: Ships' Muster Books, Adm. 38/8641.

25. Public Record Office: Captains' Logs, Adm. 51/3731/5. Unpublished Crown copyright material in the Public Record Office, London, has been reproduced by permission of the Controller of H. M. Stationery Office. p. 589 .

26. See, e.g., "Pipp's Cruise in the 'Violet," United Service Magazine, April 1851,

27. “Mr. Snigsby's Yacht," United Service Magazine, May 1852, p. 117.

28. The name is surely significant: Hannay prided himself on his descent from the Maxwells.

29. "The Court-Martial," pp. 46-47.

30. Public Record Office: Admiralty In-Letters (Adm. 1/5548).

31. "The Court-Martial," pp. 48-49. 
32. Public Record Office: Admiralty In-Letters (Adm. 1/5548). These charges are paraphrased in "The Court-Martial."

33. "The Court-Martial," p. 49.

34. Public Record Office: Admiralty In-Letters (Adm. 1/5548).

35. "The Court-Martial," p. 49.

36. Ibid., p. 48.

37. Ibid., p. 50.

38. Public Record Office: Admiralty In-Letters (Adm. 1/5548).

39. “The Court-Martial," p. 51.

40. Public Record Office: Admiralty Digest (Ind. 12250).

41. "Mr. Adair's Narrative," United Service Magazine, June 1854, pp. 213-14.

42. Ibid., p. 208.

43. United Service Magazine, September 1845, p. 125; Public Record Office: Ships' Muster Books, Adm. 38/8990. Writing in his diary seven years later, Hannay erroneously placed his return from the Mediterranean aboard the Scout in the autumn of 1845 .

44. "The Family Ship," United Service Magazine, October 1852, p. 250. The Cambridge may well have furnished at least part of the inspiration for "The Family Ship." According to the Naval Biographical Dictionary (London, 1849), p. 48, Capt. Barnard was married to a Miss Parkin, and Parkin, it will be remembered, was the name of his second-in-command.

45. Ibid., p. 254. I have been unable to discover any naval captain of Hannay's day who corresponds exactly to his description of "Kraggles," but his repeated references to him lead me to believe that this fictional character must have had some basis in fact.

46. See "The Sailors' Home," Household Words, II (22 March 1851), 612-15.

47. "Mr. Snigsby's Yacht," United Service Magazine, November 1851, p. 409.

48. Ibid., February 1852, p. 264.

49. According to family tradition, Hannay learned Latin from a priest on Malta. In one version of this story, that priest was "Father Prout" (Francis Sylvester Mahony), of whom Hannay was very fond in later life; $I$ have not been able to verify this.

50. “Aboard the Training Ship," p. 561.

\section{II}

1. James Grant, The Newspaper Press (London, 1871), 1, 310. Hannay's friend and sponsor-to-be Thackeray was contributing articles on literature and painting to the Morning Chronicle while Hannay was employed by that paper, but according to Hannay's diary the two men did not meet until April 1848, after both had left the Chronicle.

2. Glances Back Through Seventy Years (London, 1893), I, 323-24.

3. Idler, I (1856), 169.

4. Sutherland Edwards averred that, although he and Hannay "considered ourselves jointly responsible for what appeared in its columns," the attacks against Jerrold in Pasquin were all written by Hannay. See M. H. Spielmann, The History of "Punch" (London, 1895), pp. 348-49.

5. Vizetelly, I, 323.

6. Reminiscences of Thirty-Five Years of My Life (London, 1895), p. 45.

7. Spielmann refers to Hannay as the founder of the Puppet-Show (p. 354) and suggests that the magazine was in competition with Pasquin, edited by Edwards ( $\mathrm{p}$. 240 ). In view of the fact that more than five months elapsed between the last issue of Pasquin and the first issue of the Puppet-Show, and the fact that both men were associated with both magazines, the notion of a rivalry between either the writers or the magazines is erroneous. Just who did edit the Puppet-Show is in doubt. Vizetelly rather ambiguously refers to one John Bridgeman who "at the time... acted as editor," but it does seem clear, from internal as well as external evidence, that Hannay 
and Edwards had a powerful hand in running the magazine, at least during its earliest and best months, whether they actually served as editors or not.

8. Vizetelly, I, 330. This prospectus also appeared, in a slightly different version, as an advertisement in the rival Man in the Moon in August 1848.

9. Vizetelly, I, 323; Spielmann, p. 348.

10. Vizetelly, I, 330-31.

11. Ibid., I, 323 .

12. A number of the Puppet-Show's most spirited attacks are referred to in Spielmann, pp. 239-40.

13. See, e.g., 13 May 1848, p. 68, and 1 July 1848, p. 121.

14. See, e.g., 10 June 1848 , p. 104.

15. See, e.g., 18 November 1848, p. 105.

16. For other examples of this sort of thing see 28 October 1848 , p. $80 ; 9$ December 1848, p. 139; 30 December 1848, p. 155; III, 15.

17. Lancet, 12 August 1848, p. 192.

18. W. M. Rossetti, Ruskin: Rossetti: Preraphaelitism (London, 1899), p. 33.

19. Literary Recollections and Sketches (London, 1893), p. 302.

20. Reminiscences of Thirty-Five Years of My Life (London, 1895), pp. 43-44.

21. "The Newspaper Press: Half a Century's Survey," Blackwood's Edinburgh Magazine, CLXI (May 1897), 706.

22. Ialer, I (1856), 256-57.

23. MS letter to David Hannay, 26 February 1878.

24. Diary for 15 June 1853 .

25. Some Reminiscences of William Michael Rossetti (London, 1906), I, 163-64.

26. Pre-Raphaelitism and the Pre-Raphaelite Brotherhood (New York, 1905), I, 231.

27. Diary, Vol. II; a note opposite entries for 8 March-12 March 1854.

28. The Letters and Private Papers of William Makepeace Thackeray (Cambridge, Mass., 1945), II, 553-54.

29. Novels and Novelists from Elizabeth to Victoria (London, 1858), II, 358.

30. Espinasse, p. 305. The fact that Hannay's father had been Carlyle's schoolmate at the Annan grammar school probably helped to account for his interest in the young author.

31. Latter-Day Pamphlets (London, 1898), p. 255.

32. Ibid., p. 91.

33. Blackwood's Edinburgh Magazine, LXVII (June 1850), 64I-58.

34. In Blackwood $v$. Carlyle Hannay speculates that the reviewer must have been Alison (p. 18), but, as Hannay discovered later (MS letter to Allingham, 10 May 1852), the actual offender was Aytoun.

\section{III}

1. Spielmann, p. 354.

2. Diary: retrospective note, opposite entry for 5 April 1853.

3. He collaborated on three additional articles with W. H. Wills. See Bibliography.

4. III (30 August 1851), 544-49. See also my "The Genesis of Jo the Crossing. Sweeper," JEGP, LX (January 1961), 44-47.

5. "The Queen's Head," by Hannay and Wills, originally published in Household Words on 21 February 1851, pp. 510-13, has been called "the first literary article attaching a popular interest to the adhesive postage stamp and the method of its manufacture" (F. J. Melville, Introduction to The Queen's Head, published separately by "The Melville Stamp Books" [London: 1910], p. 6).

6. R. C. Lehmann, Charles Dickens as Editor (New York, 1912), p. 58. Cf. pp. 65, 69 , and 85 .

7. See above, pp. 18-21. 


\section{Notes on Pages 70-104}

8. The diaries for December 1855 and the early months of 1856 show how frequent were the meetings between Hannay and Wilberforce during this period.

9. Lord Beaconsfield and Other Tory Memories (London, 1907), p. 172.

10. Ralph Straus, Sala (London, 1942), p. 113.

11. Diary, 16 April 1855.

12. Diary, 1 April 1856.

13. This conflict has been discussed at length by the biographers of Thackeray and Dickens. See Gordon N. Ray, "Dickens versus Thackeray: The Garrick Club Affair," $P M L A$, LXIX (September 1954), 815-32; Edgar Johnson's rejoinder, PMLA, XXI (March 1956), 256-59; and Mr. Ray's reply to Mr. Johnson, PMLA, LXXI (March 1956), 259-63.

14. The following five paragraphs draw on Daily News reviews of Henry Esmond, 2 November 1852; The English Humourists, 4 July 1853; The Newcomes, No. 1, 1 October 1853; and The Newcomes, Nos. 1-19, 7 April 1855; as well as a general article, "William Makepeace Thackeray," Illustrated Times, I (20 October 1855), 325-26.

15. Hannay's dealings with the eccentric proprietor of the Westminster were somewhat uneasy. Though the article on "The Beard" was finished in March 1854 it was not published until July, after Chapman had induced Hannay to make substantial revisions in it. Chapman himself rather gratuitously added the four final paragraphs, as Hannay wryly wrote in his diary, "for ornament, I suppose, and about as ornamental, as a tail appended to a gentleman's figure would bel" Hannay's estimate of John Chapman is worth quoting: "Poor Chapman! The most spiritualistic-romantic of publishers! A melancholy, dark-eyed, turned down-collared man something like an Inspired Bagman; an Emersonian policeman in plain clothes. He once read me part of an essay on God, but I kept first my temper and then my countenance. Yet is there a kind heart in the man. When $I$ was ill, and unable to write my Pedigree and Heraldry by reason of rheumatism, he called on me" (Diary: retrospective note opposite entries for 8 March-12 March 1854).

16. Diary, 9 February 1854.

17. He also reviewed Tupper's Rides and Reveries of the Late Mr. Aesop Smith in the New Quarterly Review, VII (February 1858), 48-51.

18. See, e.g., Espinasse, pp. 310-11.

19. Gordon N. Ray (ed.), The Letters and Private Papers of William Makepeace Thackeray (Cambridge, Mass., 1945), III, 465-66.

20. Young Dante Gabriel Rossetti was very much attracted by Poe's work: see, e.g., W. M. Rossetti, Dante Gabriel Rossetti: His Family Letters (London, 1895) and G. B. Hill, Letters of Dante Gabriel Rossetti to William Allingham (London, 1897), passim.

21. MS letter.

22. A subscription to Hannay's course cost fifteen shillings; Carlyle's managers, when his earlier fame was at its height thirteen years before, had charged a guinea for the six lectures on "Heroes, Hero-Worship, and the Heroic in History" (Spectator, XIII [2 May 1840], 429).

23. Espinasse, p. 306; cf., e.g., Examiner, 18 June 1853, pp. 390-91, and Spectator, XXVI (18 June 1853), 585.

24. Spectator, XXVIII (15 July 1854), 758; Athenaeum, 29 July 1854, pp. 934-35; Critic, XIII (I September 1854), 472-73; Literary Gazette, 23 September 1854, p. 819; Diary, 11 July 1854; William Bell Scott, Autobiographical Notes (New York, 1892), II, 32; W. M. Rossetti, Ruskin: Rossetti: Preraphaelitism (London, 1899), p. 34; G. B. Hill, Letters of Dante Gabriel Rossetti to William Allingham (London, 1897), pp. 56-57.

25. D. A. Wilson, Carlyle on Cromwell and Others (London, 1925), p. 40.

26. The resemblance, which can be clearly seen in the magazine's contents, extended even to the Shakesperian motto that was printed above the title on the front page of each number (beginning with the third): "A guest that best becomes the table." 
(Compare "Familiar in their Mouths as HOUSEHOLD WORDS" in the same place in each number of Dickens' "weekly journal.")

27. The editor of the Welcome Guest was Hannay's old adversary G. A. Sala: unless Vizetelly, the publisher of the magazine, had more to do with commissioning these articles than the note suggests, Sala and Hannay seem to have settled their feud by this time.

28. Examiner, 8 September 1866, p. 570.

29. A History of Nineteenth Century Literature (New York, 1902), p. 384.

30. MS letter (University of Illinois).

31. MS letter (University of Illinois). Meadows had married Margaret's mother's sister, a daughter of John Henning, the sculptor. Margaret's father, Joseph Thompson, was a cashier in the Oriental Bank Corporation and emigrated to Australia with the rest of his family a few days after his daughter's marriage.

32. MS letter (University of Illinois).

33. John Cordy Jeaffreson, A Book of Recollections (London, 1894), I, 145. $222 \mathrm{n}$.

34. W. M. Rossetti, Dante Gabriel Rossetti: His Family-Letters (London, 1895), I,

35. Some Reminiscences of William Michael Rossetti, I, I65.

36. Jeaffreson, I, 144.

37. Espinasse, p. 325.

38. Jeaffreson, I, 159-60.

39. Dumfries Courier, 24 March 1857. He purposely dated the address from Canonbury rather than Islington. He told Jeaffreson: "Everybody at Dumfries knows that Islington is a third-rate suburb of London; but in their ignorance of this overgrown capital the voters of my native borough will think that Canonbury is my country-seat. Canonbury rings upon the ear with historic significance. It sounds as well as Gunnersbury" (Jeaffreson, I, 153-54).

40. Dumfries Courier, 24 March 1857.

41. Quarterly Review, CII (July 1857), 40-41.

42. Hannay told Espinasse that Lord Stanley "styled him 'the Douglas Jerrold of Conservatism'" (Espinasse, p. 311). Lord Stanley seems to have taken Hannay into his confidence regarding matters of state and politics: two very explicit letters from him to Hannay, marked "Private," have survived, dated 12 December 1859 and 27 February 1861, respectively.

\section{IV}

1. Espinasse, p. 311.

2. Diary entries for 20 and 21 July 1860.

3. Cumulative Diary entry for 21-30 September 1860 .

4. Espinasse, p. 312.

5. See Carlyle's letter of 13 January 1861 to Hannay, in which he praises Hannay's decision to accept the Edinburgh job and refers understandingly to the loss of the real or fancied "charms" of London and the "necessity of a solid income" for one in Hannay's position. The letter was published in PMLA, LXXI (June 1956), 544.

6. MS letter from F. Conington to Margaret Hannay, 10 August 1860; T. E. Kebbel, Lord Beaconsfield and Other Tory Memories (London, 1907), p. 181.

7. Some of Hannay's best Courant writing was collected in Characters and Criticisms (Edinburgh, 1865).

8. His long and important association with the Cornhill Magazine began while he was in Edinburgh, in February 1863. See Bibliography and below, pp. 152-53, 157-61.

9. Cf. Hannay's article on "Provincialism," which was obviously inspired by his Edinburgh experience, in the Cornhill, XI (June 1865), 673-81.

10. Very early in his editorship, he wrote: "For our own part, we see nothing but palliatives as the product of most modern philanthropy; and we fear that 'baling out' 


\section{Notes on Pages 134-143}

evil (to use a nautical metaphor) is all that private effort will do-unless the whole 'masters' of the country take up the responsibility of the condition of their men with the same spirit, energy, and ability that was shown in the government of the early state of society by the feudal monarchs, and baronage, and the mediaeval church" (29 September 1860 , p. 2).

11. Begg's biographer surely had some justice on his side when he protested that "it is quite true that Dr. Begg never 'edited the Septuagint or the Greek Testament,' a crime in which, so far as I know, he shares with all the Scottish, and certainly with 999 out of every 1000 English, Episcopal ministers of the present and preceding generations" (Thomas Smith, Memoirs of James Begg, D.D. [Edinburgh, 1888], II, $381)$.

12. In one celebrated case, to which Hannay paid a great deal of editorial attention, a divinity student named John Anderson qualified for the Church of Scotland ministry by passing an examination administered by the Presbytery of Weem. One member of the examining committee dissented from its verdict and carried his protest first to the Synod of Perth and Stirling, which upheld the Presbytery's finding, and then all the way to the General Assembly, where the examination questions and Anderson's responses were made public. Many of the questions were shown to be ludicrously easy (e.g., How many tribes of Israel were there?), and Anderson's responses were generally mediocre or worse. In defense of Anderson, it was stated in the General Assembly that his performance was probably at least as good as the average of other successful candidates, "even of the metropolitan Presbytery" (see, e.g., 26 May 1863 , p. 2).

13. I find the internal evidence (style, content) quite convincing, though this is not a review that Hannay ever reprinted under his own name or otherwise acknowledged as his. There are two pieces of external evidence that strengthen my case. One is an epigram, "On an Answerer of Renan," which Hannay reprinted in Characters and Criticisms, a collection consisting almost entirely of work done in Edinburgh. The epigram reads:

You answered Renan? That is strange, if true.

Men only answer when they're spoken to,

And Renan speaks to scholars, not to you (p. 132).

It may be that he reread this review while selecting material from the Courant for inclusion in the volume, dashed off this little verse, and chose to insert it as a filler instead of the longer essay. The second bit of external evidence is the belief of Mrs. Oliphant, Tulloch's biographer, that Hannay's attacks in the Courant on Tulloch's classical scholarship helped to drive the Principal "to the verge of madness" ( $A$ Memoir of the Life of John Tulloch [Edinburgh, 1888], p. 166). In the files of the Courant during the years of Hannay's editorship, I have found many favorable references to Tulloch, and only two unfavorable ones: this review and a criticism (in a leader of 31 May 1861) of some remarks, having nothing to do with classical scholarship, made by Tulloch before the General Assembly. In point of fact, Tulloch's illness (which was sympathetically reported in the Courant) occurred the year before this review was printed, and one doubts whether his malady could have been produced by the sort of cause which Mrs. Oliphant adduces. Though her account is muddled in its details, I see no reason to doubt that Tulloch was upset by the review of The Christ of the Gospels, as well he might have been.

14. Edinburgh Courant, 6 January 1862, p. 2.

15. T. H. S. Escott, Masters of English Journalism (London, 1911), p. 285.

16. In a letter which appeared in the Edinburgh morning papers that day. See, e.g., the Scotsman, 5 December 1864, p. 4. Commenting on this announcement, the Edinburgh correspondent of the Liberal Morning Star conceded that Hannay had furthered the cause of Conservatism in that city with "rare ability and skill. The Courant during its present editorship has contained better writing by far than any of 
the other Edinburgh morning journals.... I would willingly take odds on Mr. Hannay against any man in Scotland for the neat turn of a sentence or the point of an epigram. ... Mr. Hannay's epigrams ... not only stab, but they glitter while they stab. And this prevailing neatness of expression and statement, the sudden intrusion at times of splendour and rich colour amongst the dry details of a subject-this coruscation of fancy and glitter of wit in the columns of a morning Edinburgh paper is somewhat unusual.... It is this power of giving you by implication, or suggestion, or remote allusion, something more than you expect or bargain for which really constitutes good writing; and this power the editor of the Courant possesses in a remarkable degree" (10 December 1864, p. 5).

17. Edinburgh Courant, 25 February 1865, p. 3.

18. "The Scot at Home," Cornhill Magazine, XIV (August 1866), 252.

19. Espinasse, p. 390.

20. Espinasse, pp. 312-13. 92.

21. [Annie Thomas Cudlip], "James Hannay," Temple Bar, XXXVIII (April 1873),

1. From the Pall Mall Gazette's Prospectus, which was reprinted in the special ten thousandth number of the paper, 14 April 1897, p. 2.

2. Ibid., p. 1. Greenwood's essay, "Birth and Infancy of the 'Pall Mall Gazette," is the best available account of its subject; cf. J. W. Robertson Scott, The Story of the Pall Mall Gazette (London, 1950).

3. According to Hannay's friend Kebbel, Hannay "was enticed from Edinburgh to London by the promise of $£ 600$ a year" on the Pall Mall Gazette (Kebbel, p. 222).

4. See, e.g., the kind words about him written by one of his contributors, whose political views diverged sharply from Greenwood's: John Morley, Recollections (London, 1917), I, 168-69.

5. A contemporary observer remarked: "Its tone has from the first been aristocratic -the tone of the club window, of the smoking room of the House of Commons, and of the drawing-room. You read your column or column and a half of vigorous polished matter-read it with relish. It is keen, scholarly, and trenchant. You feel that you are reading the work of a man who has cleared his mind of all cant before he took up his pen at all, and that possessing strong common sense he possesses it with a calm and perhaps cynical temper which sees and hears everything and sees through everything" (Charles Pebody, English Journalism and the Men Who Have Made It [London, 1882], p. 171).

6. Some early reviews and articles which may well be by Hannay: review of Sanford and Townsend's The Great Governing Families of England, 23 March 1865, pp. 10-11; review of two volumes of Scottish family histories, 1 May 1865, p. 11; three articles on "The Scotch General Assemblies" (27 May 1865, pp. 10-11; 29 May 1865, pp. 9-10; 31 May 1865, p. 10); "French Naval Officers," 23 June 1865, pp. 10-11; "Electioneering," 12 July 1865, p. 2; review of G. de Landelle's Les Marins, 5 August 1865, p. 11; review of "Mr. Veitch's Greek Verbs," 11 April 1866, p. 13; review of an edition of Horace by J. E. Yonge, 16 October 1867, p. 12. In view of what Robertson Scott, Espinasse, and others have written about Hannay's association with the Pall Mall Gazette, his contribution to it was clearly much greater than this brief, tentative list would suggest. Some letters (now in the Ewart Public Library, Dumfries) which Hannay wrote in 1866-67 to the Scottish publisher David Douglas make it clear that he contributed frequent articles and reviews during those years: in one letter, he says that "I have pretty well the pick of the reviewing" in the Pall Mall, but "Leaders I rarely write" (17 January 1867). One of Hannay's old adversaries, Edmund Yates, writing as "The Flâneur" in the Morning Star, referred to him as the "sub-editor" (13 February 1865, p. 5); Yates's numerous attacks on the fledgling Pall Mall Gazette and on Hannay in particular (cf. 
Morning Star, 2 January 1865, p. 5; 9 January 1865, p. 5; and 20 February 1865, p. 5) drew a sharp rebuttal ("A New Type of Journalist," Pall Mall Gazette, 18 February 1865 , p. 6), which is very much in Hannay's vein. Yates's hurt response to this was published in the Morning Star on 27 February 1865, p. 5. On Hannay's contributions to the Pall Mall Gazette after 1868, see pp. 163-67.

7. See, e.g., the leader of 14 March 1866, p. 1.

8. For confirmation, see Espinasse, p. 315; also Escott, Masters of English Journalism, p. 253.

9. W. M. Rossetti, Dante Gabriel Rossetti: His Family Letters, II, 184.

10. "Recent British Humourists: Aytoun, Peacock, Prout," North British Review, XLV (September 1866), 85.

11. MS letter, undated but obviously written December 1866 .

12. An 1865 review in the Reader asked about Hannay: "How is it that, having done thus much, he has not done more? ... Epigrammatic without any straining, versatile without being verbose, original without being affected, he has somehow failed to make the impression which might have been expected on the age. The truth is, he has frittered away, almost wasted we would say, his really great powers. There is nothing of his to which we can point, and say it will live. All is promise. No doubt the kind of writing which he has adopted is very lucrative, but though it produces aes, is not aere perennius. The misfortune is doubly aggravated, because men of Mr. Hannay's stamp are so scarce" (V [24 June 1865], 701).

13. Fortnightly Review, II (1 September 1865), 265.

14. Hannay had made the same point at greater length in a Temple Bar essay of 1867, "Thackeray on Swift," XXI (October 1867), 322-30.

15. Espinasse indicates (p. 316) that Hannay contributed other work to the Imperial Review, but again it is impossible to identify it positively. Some Imperial Review essays which bear the Hannay stamp include "The Scottish Lesson of the Edinburgh Banquet," II (2 November 1867), 387-88; "Bohemianism," II (7 December 1867), 511-12; "Light Literature in Parliament," II (23 November 1867), 462-63; and "Too Little Latin and Greek," II (30 November 1867), 485-87. A review of Earl Russell's Life of Charles James Fox, I (12 January 1867), 53-54, is very much in Hannay's style, and repeats an epigram about the author which had appeared in an Edinburgh Courant leader on 19 February 1864, p. 2. (Like Euclid's "point," Russell had "position without magnitude.") Hannay's work was frequently praised in the Imperial Review: Three Hundred Years of a Norman House was given a highly favorable notice (I [19 January 1867], 87-89); he was ranked with Thackeray, Lytton, and Lever in an article on "Fiction Not Literature" (II [28 September 1867], 274-75); and an essay on "Bores (III [25 January 1868], 80-81) drew support from a quotation from Eustace Conyers. The "Cad" papers seem to have scored a popular success: the numbers of the Imperial Review containing the first nine articles had to be reprinted. (See the advertisement in III [27 June 1868], 611, which was repeated each week for the next five months.)

16. Espinasse, p. 323.

17. The antithesis of the Literary Cad, as might be expected, is Thackeray, who wrote "the language of a gentleman" (IV [17 October 1868], 365). In the first article of the series, Hannay said that "Thackeray, the great Snobographer, hated a Cad much more than he hated a Snob" (III [21 March 1868], 272), and cited an anecdote to support his point.

18. Another source of disappointment is recorded by Espinasse. "It was understood that if a vacancy in the Chair of English Literature in Edinburgh University occurred when the Conservatives were in office it would be given to Hannay. But when W. E. Aytoun died, Lord Palmerston was Prime Minister and Sir George Grey having, as Home Secretary, the selection of a successor to Aytoun, he appointed the able and accomplished biographer of Milton, Professor Masson, to the chair vacant through 


\section{Notes on Pages $155-165$}

Aytoun's death. Had Aytoun lived for another year, with the return of the Conservatives to office, Hannay would very probably have been his successor" (pp. 317-18).

19. "James Hannay," Temple Bar, XXXVIII (ApriI 1873), 92-93. Annie Thomas (Mrs. Cudlip) identifies herself as the author of this anonymous obituary notice in a MS letter of 2 April 1873 to Hannay's daughter Elizabeth.

\section{VI}

1. Hannay was first offered the consulate at Brest, but, because his predecessor at Barcelona, R. Levinge Swift, wanted to be transferred to Brest for personal reasons, and Hannay was willing to effect an exchange, he was ultimately appointed to the Spanish post (Public Record Office: F.O. 27/1720).

2. MS letter of 21 July 1868.

3. MS letter of 17 July 1855.

4. Hannay's article "From Pittenweem to Barcelona," Temple Bar, XXV (December 1868), 27-39, furnishes a detailed account of the journey.

5. Public Record Office: F. O. 72/1190.

6. XXII, 556 .

7. Ibid., pp. 561-62.

8. "Spain, and Her Revolution," Cornhill Magazine, XXIII (February 1871), 188.

9. "Spain: Her Manners and Amusements," Cornhill Magazine, XXV (January 1872), 75.

10. "Spain, and Her Revolution," p. 176.

11. "Spain: Her Social Condition," Cornhill Magazine, XXIV (October 1871), 460.

12. Ibid., pp. 467-68. 182.

13. "The Lions of Catalonia-Barcelona," Cornhill Magazine, XX (August 1869),

14. Ibid., p. 195.

15. Ibid.

16. “James Hannay," Temple Bar, XXXVIII (April 1873), 91.

17. "The Consular Service," p. 564.

18. See Public Record Office: F. O. 72/1190, 1218, 1247, 1281, 1321, and 1350; F. O. $185 / 495,496,505,514,525,526,538,550,551,552$, and 553; F. O. $637 / 10$ and 11; F. O. $638 / 9,10,11,14$, and 16. These official dispatches should be supplemented by British Museum Additional Manuscripts 39000. f. 115, and 39001, ff. 35, 251, 281, 312, and 317, private letters from Hannay to A. H. Layard about conditions in Catalonia in 1872.

19. British Museum Add. MS 39001 , f. 338.

20. British Museum Add. MS 39001, f. 370.

21. An extremely cordial letter from Greenwood, dated 30 September 1868, inviting Hannay to contribute to the Pall Mall from Spain has survived, and the first part of another, dated 20 December 1870, has also been preserved.

22. As the same article makes clear, the aftermath of this episode revealed another, less comic, side of Spanish life: once the revolt was put down, a number of villagers were butchered on the flimsiest evidence of complicity. 


\section{BIBLIOGRAPHY}

I. Books by James Hannay (first editions).

Biscuits and Grog (London: Darling, 1848).

A Claret-Cup (London: Darling, 1848).

Hearts are Trumps (London: Kent [1848]).

King Dobbs (London: Darling, 1849).

Singleton Fontenoy, 3 volumes (London: Colburn, 1850).

Blackwood v. Carlyle (London: Effingham Wilson, 1850).

Sketches in Ultra-Marine, 2 volumes (London: Addey, 1853).

Satire and Satirists (London: Bogue, 1854).

Sand and Shells (London: Routledge, 1854).

Eustace Conyers, 3 volumes (London: Hurst and Blackett, 1855).

Essays from "The Quarterly Review" (London: Hurst and Blackett, 1861).

A Brief Memoir of the Late Mr. Thackeray (Edinburgh: Oliver and Boyd, 1864).

Characters and Criticisms (Edinburgh: Nimmo, 1865).

A Course of English Literature (London: Tinsley, 1866).

Three Hundred Years of a Norman House (London: Tinsley, 1867 [1866]).

Studies on Thackeray (London: Routledge [1869]).

II. Articles and major reviews by James Hannay. (This list does not include the numerous paragraphs, poems, epigrams, or other short pieces by Hannay which appeared in periodicals, or any of the huge body of newspaper work definitely identifiable as his. References to some of this material are made, where appropriate, in footnotes in the text; some of the more important newspaper work is separately listed below, under III. I have refrained from listing anything which cannot be ascribed to Hannay on the basis of evidence in his diary or other unimpeachable testimony.)

\section{All the Year Round}

"Ships and Crews," I (20 August 1859), 389-94.

"Portsmouth," I (24 September 1859), 517-23.

"Aboard the Training Ship," I (8 October 1859), 557-62.

"Cherbourg. I. The Way There," II (10 December 1859), 147.51.

"Cherbourg. II. In the Town," II (17 December 1859), 180-84.

"Cherbourg. III. Among the Sailors," II (24 December 1859), 195-98.

Athenaeum (unless otherwise indicated, all these are reviews)

Henry Bliss, Robespierre: a Tragedy, 7 October 1854, pp. 1194-95.

Revelations of a Slave Trader; or, Twenty Years' Adventures of Captain Canot, 14 October 1854, pp. 1230-31.

John Oldmixon, Gleanings from Piccadilly to Peru, 21 October 1854, pp. 1260-61.

Earl of Carlisle, Diary in Greek and Turkish Waters, 28 October 1854, pp. 1295-96.

Edward T. Perkins, Na Motu; or, Reef-Rovings in the South Seas, 11 November 1854, pp. 1360-61.

The Table-Talk of John Selden. With Notes by David Irving, 2 December 1854, p. 1458.

Martin Tupper, Proverbial Philosophy, 18th Edition, 30 December 1854, pp. 1583-85.

Detached Thoughts and Apophthegms, Extracted from Some of the Writings of Archbishop Whately, 6 January 1855, pp. 9-10.

$A$ Handbook of Proverbs. Collected by Henry G. Bohn, 20 January 1855, pp. 73-74.

Frank Marryat, Mountains and Molehills, 3 March 1855, p. 259.

J. Parton, The Life of Horace Greeley, 17 March 1855, pp. 316-18. 


\section{JAMES HANNAY}

Bayard Taylor, Pictures of Palestine, Asia Minor, Sicily, and Spain, 28 April 1855, pp. 481-82.

Minute Book Kept by the War Committee of the Covenanters in the Stewartry of Kirkcudbright, 5 May 1855, p. 516.

Richard F. Burton, Personal Narrative of a Pilgrimage to El-Medinah and Meccah (Vols. I and II), 28 July 1855, pp. 865-66.

"A Journalist," Memoirs of James Gordon Bennett and His Times, 15 September 1855, pp. 1049-50.

M. Tullii Ciceronis Orationes. With a Commentary by George Long (Vol. II), 17 November 1855, pp. 1330-31.

Robert Edgar Hughes, Two Summer Cruises with the Baltic Fleet, 15 December 1855 , p. 1463.

Richard F. Burton, Personal Narrative of a Pilgrimage to El-Medinah and Meccah (Vol. III), 2 February 1856, pp. 135-36.

Selections from the Writings of Dr. Whately, Archbishop of Dublin, 12 April 1856, pp. 456-57.

John Anderson, $\boldsymbol{A}$ History of Edinburgh, from the Earliest Period to the Completion of the Half-Century, 1850, 10 May 1856, pp. 580-81.

Charles John Andersson, Lake Ngami, 31 May 1856, pp. 677-78.

George Coggeshall, $A$ History of American Privateers and Letters-of-Marque, 28 June 1856, pp. 801-02.

Richard F. Burton, First Footsteps in East Africa, 19 July 1856, pp. 895-96.

William Balfour Baikie, Narrative of an Exploring Voyage up the Rivers Kwora and Binue in 1854, 9 August 1856, pp. 985-86.

M. Tullii Ciceronis Orationes. With a Commentary by George Long (Vol. III), 27 September 1856, pp. 1184-86.

Sir Harris Nicolas, The Historic Peerage of England. Revised by William Courthope, 31 January 1857, pp. 145-46.

Peter Lorimer, Patrick Hamilton, the First Preacher and Martyr of the Scottish Reformation, 21 February 1857, pp. 241-42.

Joseph Irving, The History of Dumbartonshire, from the Earliest Period to the Present Time, 15 August 1857, pp. 1030-31.

Donald MacLeod, Life of Mary, Queen of Scots, 5 September 1857, pp. 1108 09.

Charles Daubeny, Lectures on Roman Husbandry, 19 September 1857, pp. 1172-73.

W. M. Thackeray, Miscellanies: Prose and Verse; and "M. A. Titmarsh," The Irish Sketchbook (New Edition), 3 October 1857, pp. 1229-31.

Decii Junii Juvenalis et $A$. Persii Flacci Satirae. With a Commentary by Arthur John Macleane, 21 November 1857, pp. 1447-48.

James A. Sharp (ed.), Memoirs of the Life and Services of Rear-Admiral Sir William Symonds, 23 January 1858, pp. 105-07.

James Grant, Memoirs of James, Marquis of Montrose, 20 March 1858, pp. 363-64.

Robert Chambers, Domestic Annals of Scotland from the Reformation to the Revolution, 22 May 1858, pp. 651-53.

Marquis of Kildare, The Earls of Kildare, and Their Ancestors. Second edition, 5 June 1858, pp. 711-12.

Rear-Admiral Hercules Robinson, Sea Drift, 12 June 1858, p. 746.

Lord Ravensworth, The Odes of Horace, 3 July 1858, pp. 10-12.

M. Tullii Ciceronis Orationes. With a Commentary by George Long (Vol. IV), 21 August 1858, pp. 225-26.

P. Vergili Maronis Opera. The Works of Virgil. With a Commentary by John Conington, M. A. (Vol. I), 4 September 1858, pp. 291-92.

[Article, signed "H.'], "Literary Parallels," 4 September 1858, pp. 298-300. 


\section{BIBLIOGRAPHY}

Daniel Gurney, Supplement to the Record of the House of Gournay, 18 September 1858, pp. 359-60.

A Handbook of the Principal Families in Russia, Originally Written in French, by Prince Paul Dolgorouky. Translated into English, with Annotations and an Introduction. By F. Z., 16 October 1858, pp. 484-85.

Ellen J. Millington, Heraldry in History, Poetry, and Romance, 20 November 1858, pp. 644-45.

General Sir Howard Douglas, On Naval Warfare with Steam, 4 December 1858, pp. 716-17.

Thomas, Earl of Dundonald, Narrative of Services in the Liberation of Chili, Peru, and Brazil, from Spanish and Portuguese Domination, 1 January 1859, pp. 11-13.

John W. Burgon, The Portrait of a Christian Gentleman. A Memoir of Patrick Fraser Tytler, 9 April 1859, pp. 481-82.

Evelyn Philip Shirley, The Noble and Gentle Men of England, 21 May 1859, pp. 673-74.

Hans Busk, The Navies of the World, 30 July 1859, pp. 141-43.

Sir Bernard Burke, Vicissitudes of Families, and Other Essays, 3 September 1859, pp. 298-99.

Henry George Robinson, The Odes of Horace Literally Translated into English Verse, with Notes (Vol. II, Part II), 17 September 1859, Pp. 362-63.

A. H. Clough, Plutarch's Lives. The Translation Called Dryden's Corrected from the Greek and Revised, 24 September 1859, pp. 391-92.

Theodore Martin, The Odes of Horace: Translated into English Verse, with a Life and Notes; Richard W. O'Brien, The Odes of Horace: Translated into English Verse, with the Original Measures Preserved Throughout; Rev. Robert Corbet Singleton, The Works of Virgil Closely Rendered into English Rhythm; Juvenal, Persius, Sulpicia. A New Version, 3 March 1860, pp. 298-99.

Martin F. Tupper, Three Hundred Sonnets, 5 May 1860, p. 611.

Alexander Leighton, Curious Storied Traditions of Scottish Life, 12 May 1860, p. 648.

Lieut. A. H. Alston, Seamanship, and its Associated Duties in the Royal Navy; Commander James H. Ward, U. S. N., A Manual of Naval Tactics, 9 June 1860, pp. 784-85.

Sir Bernard Burke, A Second Series of Vicissitudes of Families, 18 August 1860, pp. 220-21.

William Whewell, The Platonic Dialogues for English Readers, 6 October 1860.

Atlantic Monthly

"Douglas Jerrold," I (November 1857), 1-12.

Cornhill Magazine

"The Inner Life of a Man-of-War," VII (February 1863), 172-88.

"Sea Fights, Ancient and Modern," VIII (October 1863), 410-28.

"A Scotchman in Holland," VIII (November 1863), 539-55.

"Bohemians and Bohemianism," XI (February 1865), 241-55.

"Provincialism," XI (June 1865), 673-81.

"Erasmus," XII (July 1865), 116-28.

"The Social History of the Navy," XII (September 1865), 374-84.

"Greenwich Hospital," XII (November 1865), 631-40.

"The Family of Temple," XII (December 1865), 749-60.

"The National Portrait Exhibition," XIII (June 1866), 743-60.

"The Scot at Home," XIV (August 1866), 238-56.

"Naval Men," XIV (October 1866), 462-79. 


\section{JAMES HANNAY}

"The Old English Chroniclers," XV (February 1867), 154-73.

"British Admirals and Their Biographers," XV (May 1867), 538-54.

"The Classics in Translations," XVI (July 1867), 109-28.

"The Satirists of the Reformation," XVI (November 1867), 609-28.

"The Three Lyrists: Horace, Burns, and Béranger," XVII (February 1868), 150-67.

"Charles Dibdin and His Songs," XVII (May 1868), 578-91.

"Martial," XIX (April 1869), 446-58.

"The Lions of Catalonia-Barcelona," XX (August 1869), 182-95.

"The Lions of Catalonia-Tarragona," XX (September 1869), 363-75.

"The Lions of Catalonia-Monserrat," XXI (June 1870), 663-76.

"The Consular Service," XXII (November 1870), 546-65.

"Spain, and Her Revolution," XXIII (February 1871), 170-91.

"Spain: Her Social Condition," XXIV (October 1871), 452-70.

"Spain: Her Manners and Amusements," XXV (January 1872), 60-76.

"The Lions of Catalonia-a Dead Lion," XXVI (July 1872), 70-89.

"The Duc de Saint Simon," XXVI (November 1872), 534-55.

"Sea Novels-Captain Marryat," XXVII (February 1873), 170-90.

Household Words

"Christmas in the Navy," II (21 December 1850), 298-300.

“A Metaphysical Mystery," II (4 January 1851), 359-60.

"Pleb-Biddlecumb Education," II (8 February 1851), 479-80.

"A Salt Growl," II (15 February 1851), 502-04.

"The Sailors' Home," II (22 March 1851), 612-15.

"The Blue-Jacket Agitation," III (5 April 1851), 36-41.

"The Great Coffee Question," III (12 April 1851), 49-53.

"The Palace of Flowers," III (26 April 1851), 117-20.

"Our Phantom Ship in Dock," III (14 June 1851), 277-80.

"In the Name of the Prophet-Smith!," III (19 July 1851), pp. 385-89 (with W. H. Wills).

"Edward Baines," III (26 July 1851), pp. 414-19 (with W. H. Wills).

"The 'Dreadnought" " III (23 August 1851), 516-19.

"Lambs to be Fed," III (30 August 1851), 544-49.

"The London Tavern," IV (18 October 1851), 73-77.

"English Songs," IV (15 November 1851), 173-78.

"The 'Merchant Seaman's Fund," IV (13 December 1851), 274-77.

"The Queen's Head," IV (2l February 1852), 510-13 (with W. H. Wills).

"The Sister-Ship," V (24 April 1852), 138-40.

"Bold Admiral Blake," V (19 June 1852), 326-31.

"London Bridge in the Afternoon," V (28 August 1852), 570-72.

"Graves and Epitaphs," VI (16 October 1852), 105-09.

"Joseph Train," VII (16 July 1853), 475-77.

Idler

"The Old Scholar," XI (24 February 1855), 76-82.

“Bagot's Youth," I (1856), 1-11, 65-76, 162-72, 256-65.

"Letter to an Administrative Reformer," I (1856), 135-41.

Illustrated London News

“On Oriental Travellers," XIX (29 November 1851), 649-50.

"A Chapter on Biography," XX (31 January 1852), 111-12.

"My Cruise with the 'Eccentric Gentleman,", XXV (30 September 1854), 311, 314-15.

Imperial Review (Series on "Cads")

I, "Introductory-Growing Powers and Influence of the Cad-His Nature and Tendencies-How Distinguished from the Snob-Cads in History," 21 March 1868, pp. 272-73. 


\section{BIBLIOGRAPHY}

II, "Cads and the Aristocracy," 28 March 1868, pp. 295-96.

IfI, "Cads and Education," 4 April 1868, pp. 319-20.

IV, "Moneyed Cads," 11 April 1868, pp. 338-39.

V, "Moneyed Cads," 18 April 1868, pp. 361-62.

VI, "Political Cads," 25 April 1868, pp. 384-85.

VII, "Political Cads," 9 May 1868, 433-34.

VIII, "Clerical Cads," 16 May 1868, 456-57.

IX, "Military and Naval Cads," 13 June 1868, p. 552.

X, "Legal Cads," 3 October 1868, pp. 313-14.

XI, "Medical Cads," 10 October 1868, p. 340.

XII, "Literary Cads," 17 October 1868, pp. 365-66.

XIII, "Newspaper Cads," 31 October 1868, pp. 411-12.

XIV, "Artistic Cads," 14 November 1868, pp. 460-61.

Leader

XV, "The Cad in Private and Domestic Life," 21 November 1868, pp. 482-84.

“James Russell Lowell," 3 July 1852, pp. 636-38.

"The Angel in the House. The Betrothal," 4 November 1854, p. 1048.

"Naval Novels," 16 December 1854, pp. 1194-95.

"History of Political Literature," 13 January 1855, pp. 43-44.

"The Chinese Empire," 10 February 1855, pp. 136-38.

"Mountains and Molehills," 7 April 1855, pp. 331-32.

"Westward Hol," 19 May 1855, pp. 474-75.

"Christian Life," 16 June 1855, pp. 583-84.

"Noctes Ambrosianae," 25 August 1855, pp. 821-22.

"The Newcomes," 8 September 1855, pp. 870-71.

National Magazine

"Sheerness Revisited," I (1857), 148-52.

"Lord Chesterfield,' II (1857), 179-82.

New Quarterly Review

"The Letters of Horace Walpole, Earl of Orford," VI (August 1857), 284-90.

"The Life of Alexander Pope," VI (November 1857), 383-89.

"Essays on the Early Period of the French Revolution," VII (February 1858), 3-8.

"The Boscobel Tracts," VII (February 1858), 13-18.

"Rides and Reveries of the Late Mr. Aesop Smith," VII (February 1858), 48-51.

“Aytoun's Ballads of Scotland," VII (August 1858), 224-29.

\section{North British Review}

"Recent Humourists: Aytoun, Peacock, Prout," XLV (September 1866), 39-55.

"George Buchanan," XLVI (March 1867), 47-76.

Quarterly Review

“Table Talk," XCVIII (December 1855), 1-31.

"British Family Histories," XCVIII (March 1856), 289-321.

“English Political Satires,” CI (April 1857), 394-441.

"Electioneering," CII (July 1857), 32-59.

"The Historic Peerage," CIII (January 1858), 28-65.

"Admiral Blake," CIV (July 1858), 1-38.

"Horace and His Translators," CIV (October 1858), 325-61.

"The Minstrelsy of Scotland," CV (April 1859), 305-41.

"Burgon's 'Life of Tytler,' CVI (July 1859), 109-37.

"Plutarch," CX (October 1861), 459-84.

Temple Bar

“Thackeray on Swift," XXI (October 1867), 322-30.

“The Literature of Satire," XXII (January 1868), 190-201.

"Recollections of a Provincial Editor," XXIII (May 1868), 175-85. 


\section{JAMES HANNAY}

"From Pittenweem to Barcelona," XXV (December 1868), 27-39.

United Service Magazine

"Pipp's Cruise in the 'Violet," " April 1851, pp. 586-97.

"Close of Pipp's Naval Career," May 1851, pp. 24-31.

"Fred. Errol's Adventure," June 1851, pp. 248-57.

“Mr. Snigsby's Yacht," August 1851, pp. 561-73; September 1851, pp. 87-99; October 1851, pp. 246-59; November 1851, pp. 402-13; February 1852, pp. 263-70; May 1852, pp. 109-20.

"Sand and Shells," October 1852, pp. 245-59; January 1853, pp. 78-87.

“The Court Martial," September 1853, pp. 37-51.

"Fitz-Gubin," November 1853, pp. 335-52; December 1853, pp. 549-64; February 1854, pp. 185-99; March 1854, pp. 380-95.

“Jack's Christmas Ashore," January 1854, pp. 43-48.

“Mr. Adair's Narrative,' June 1854, pp. 203-14.

“The Middle Watch," February 1855, pp. 220-31.

Universal Review

"Lord Dundonald's Autobiography," II (January 1860), 99-120.

"Father Prout," II (February 1860), 244-60.

Welcome Guest

"A Course of English Literature." All in II (1859): 9 April, 213-15; 16 April, 228-30; 23 April, 245-47; 30 April, 266-68; 7 May, 282-83; 14 May, 293-95; 21 May, 317-19; 4 June, 347-48; 11 June, 363-64; 18 June, 374-75; 25 June, 389-90; 2 July, 410-12; 9 July, 426-28; 16 July, 442-43; 23 July, 462-64.

“Lord Macaulay," Series 2, I (1860), 323-27.

Westminster Review

"The Poetry of the Anti-Jacobin," LVIII (October 1852), 459-79.

"Pedigree and Heraldry," LX (July 1853), 85-111.

"The Beard," LXII (July 1854), 48-67.

"Literature and Society," LXVII (April 1857), 504-25.

III. Major series of newspaper articles by James Hannay.

"Gossip from London" in the Dumfries and Galloway Courier

7 July 1857, p. 4.

18 August 1857, p. 4.

20 October 1857 , p. 4.

24 November 1857 , p. 4.

22 December 1857, p. 4.

2 March 1858, p. 4.

11 May 1858, p. 4.

22 June 1858, p. 4.

3 August 1858, p. 4.

31 August 1858, p. 4.

28 September 1858, p. 4.

16 November 1858, p. 3.

21 December 1858, p. 4.

1 February 1859, p. 4.

8 March 1859, p. 4.

5 July 1859, p. 4.

23 August 1859, p. 4.

20 September 1859, p. 4.

8 November 1859 , p. 3.

3 January 1860 , p. 4.

21 February 1860 , p. 4.

27 March 1860, p. 4.

5 June 1860 , p. 4. 


\section{BIBLIOGRAPHY}

London letters "From Our Own Correspondent" in the New York Tribune 19 April 1856, pp. 8-9.

21 April 1856, pp. 5-6.

26 April 1856, p. 7.

1 May 1856, p. 7.

3 May 1856, p. 10.

12 May 1856, p. 6.

13 May 1856, p. 6.

17 May 1856, pp. 2-3.

24 May 1856, pp. 8-9.

28 May 1856 , p. 6.

31 May 1856, pp. 8-9.

9 June 1856, p. 3.

16 June 1856, p. 6.

18 June 1856, p. 6.

21 June 1856, p. 6.

24 June 1856, p. 6.

28 June 1856, p. 6.

8 July 1856, p. 3 (two dispatches).

12 July 1856 , p. 6.

19 July 1856, p. 6.

24 July 1856, p. 6.

Letters "From an Englishman in Spain" in the Pall Mall Gazette 3 October 1868 , p. 10.

12 October 1868, p. 3.

3 November 1868 , p. 3.

5 January 1869, pp. 9-10.

2 February 1869, p. 9.

3 March 1869, pp. 8-9.

15 March 1869, p. 3.

7 April 1869, p. 10.

29 April 1869, p. 10.

7 June 1869, pp. 9-10.

30 June 1869, pp. 10-11.

26 July 1869 , p. 10.

20 August 1869, pp. 10-11.

1 October 1869, pp. 10-11.

12 October 1869, pp. 11-12.

22 October 1869, p. 10.

24 November 1869, pp. 10-11.

I February 1870, p. 6.

14 April 1870, p. 7.

9 June 1870, pp. 10-11.

19 September 1870, p. 10.

30 November 1870, pp. 11-12.

1 December 1870, p. 5.

31 December 1870, pp. 10-11.

1 February 1871, p. 5.

22 March 1871, pp. 10-11.

28 March 1871, pp. 10-11.

26 April 1871, pp. 10-11.

27 April 1871, p. 10.

28 September 1871, p. 10.

28 October 1871, pp. 4-5.

29 November 1871, p. 10. 


\section{JAMES HANNAY}

21 March 187.2, pp. 10-11.

24 May 1872 , p. 10.

28 June 1872, pp. 10-11.

27 July 1872, p. 10.

6 September 1872, pp. 9-10.

27 November 1872, p. 10.

"Sketches of Radicals" in the Press

"The Radical Platform," I (10 September 1853), 445.

"The Radical Platform Continued," I (1 October 1853), 517.

"The Radical Philosopher," I (8 October 1853), 541.

"The Radical Historian," I (22 October 1853), 589.

"The Radical Jester," I (5 November 1853), 637.

"The Radical Poet," I (12 November 1853), 661.

"The Radical Novelist," I (19 November 1853), 685.

“The Radical Lecturer," I (26 November 1853), 709.

“The Fraternal Radical," I (3 December 1853), 733.

“The Radical Mystic," I (10 December 1853), 757.

“The Radical Man of Letters," I (17 December 1853), 780-81.

"The Radical Female," II (7 January 1854); 13.

"The Radical Gentleman," II (14 January 1854), 37.

"The Unconscious Radical," II (21 January 1854), 61.

"The Radical Rank and File," II (28 January 1854), 85.

IV. Uncollected essays and sketches by James Hannay in books.

"Thieves," in Gavarni in London, edited by Albert Smith (London: Bogue, 1849), pp. 55-60.

"Edgar Allan Poe," in The Poetical Works of Edgar Allan Poe (London: Addey, 1853), pp. xi-xxx.

"A Brush with the Riff Pirates," in The Dumfries Album (Dumfries and Maxwelltown Mechanics' Institution, 1857), pp. 9-15.

"A Leaf from the Log of H. M. Brig 'Sprout,"” in The Savage Club Papers (London: Tinsley, 1857), pp. 23-36.

"Hogarth as a Satirist," in The Complete Works of William Hogarth, edited by J. Trusler and E. F. Roberts (London: London Printing and Publishing Company [1861]), pp. i-xiv.

"Memoir of Churchill," in The Poetical Works of Charles Churchill (London: Bell and Daldy, 1866), I, xi-xxxii.

V. Secondary works.

Allingham, H., and Radford, D., William Allingham: a Diary (London, 1907).

Allingham, H., and Williams, E. Baumer, Letters to William Allingham (London, 1911).

Bourne, H. R. Fox, English Newspapers (London, 1887).

Collins, Frances, Mortimer Collins: His Letters and Friendships (London, 1877).

Collins, Mortimer, Thoughts in My Garden (London, 1880).

Couper, W. J., The Edinburgh Periodical Press (Stirling, 1908).

Cowan, R. M. W., The Newspaper in Scotland (Glasgow, 1946).

Crowe, Sir Joseph, Reminiscences of Thirty-Five Years of My Life (London, 1895).

Dodds, James, The Eminent Men of Dumfriesshire (Edinburgh, 1873).

Duffy, Sir Charles Gavan, My life in Two Hemispheres (London, 1903).

Edwards, H. Sutherland, Personal Recollections (London, 1900).

Ellis, S. M., Wilkie Collins, Le Fanu and. Others (London, 1931).

Escott, T. H. S., Masters of English Journalism (London, 1911).

Escott, T. H. S., Platform, Press, Politics, and Play (Bristol [1895]).

[Espinasse, Francis], "James Hannay," Bookman, III (February 1893), 149-51; III (March 1893), 181-83.

Espinasse, Francis, Literary Recollections and Sketches (London, 1893). 


\section{BibLIOGRAPHY}

Grant, James, The Metropolitan Weekly and Provincial Press (London [1872]).

Grant, James, The Newspaper Press (London, 1871).

Greenwood, Frederick, "Birth and Infancy of the 'Pall Mall Gazette,'" Pall Mall Gazette, 14 April 1897, pp. 1-2.

Greenwood, Frederick, "The Newspaper Press: Half a Century's Survey," Blackwood's Edinburgh Magazine, CLXI (May 1897), 704-20.

Hay, Cecil, The Club and the Drawing-Room (London, 1870).

Hill, George Birkbeck, Letters of Dante Gabriel Rossetti to William Allingham (London, 1897).

Hodder, George, Memories of My Time (London, 1870).

Honouring Frederick Greenwood, Being Speeches Delivered in Praise of Him at a Dinner Held on April 8, 1905 (London, 1905).

Hunt, W. Holman, Pre-Raphaelitism and the Pre-Raphaelite Brotherhood (New York, 1905).

Huxley, Leonard, The House of Smith Elder (London, 1923).

Jeaffreson, John Cordy, $A$ Book of Recollections (London, 1894).

Jeaffreson, John Cordy, Novels and Novelists from Elizabeth to Victoria (London, 1858).

Jerrold, Blanchard, The Final Reliques of Father Prout (London, 1876).

Jerrold, Blanchard, The Life and Remains of Douglas Jerrold (Boston, 1859).

Kebbel, T. E., Lord Beaconsfield and Other Tory Memories (London, 1907).

Layard, George Somes, A Great "Punch" Editor (London, 1907).

Lehmann, R. C., Charles Dickens as Editor (New York, 1912).

Marchand, Leslie A., The Athenaeum (Chapel Hill, 1941).

Masson, David, Memories of London in the 'Forties (Edinburgh, 1908).

McDowall, William, History of Dumfries (Edinburgh, 1867).

Morley, John, Recollections (London, 1917).

Norrie, William, Edinburgh Newspapers (Earlston, 1891).

O’Byrne, William R., A Naval Biographical Dictionary (London, 1849).

Oliphant, Margaret Wilson, A Memoir of the Life of John Tulloch (Edinburgh, 1888).

Pebody, Charles, English Journalism and the Men Who Have Made It (London, 1882).

Raikes, Henry St. John, The Life and Letters of Henry Cecil Raikes (London, 1898).

Ray, Gordon N., The Letters and Private Papers of William Makepeace Thackeray (Cambridge, Mass., 1945-46).

Rossetti, William Michael, Dante Gabriel Rossetti: His Family Letters (London, 1895).

Rossetti, William Michael, Praeraphaelite Diaries and Letters (London, 1900).

Rossetti, William Michael, Rossetti Papers: 1862 to 1870 (London, 1903).

Rossetti, William Michael, Ruskin: Rossetti: Preraphaelitism (London, 1899).

Rossetti, William Michael, Some Reminiscences of William Michael Rossetti (London, 1906).

Sala, George Augustus, The Life and Adventures of George Augustus Sala (New York, 1895).

Scott, J. W. Robertson, The Story of the Pall Mall Gazette (London, 1950).

Scott, William Bell, Autobiographical Notes (New York, 1892).

Shepherd, Richard Herne, Memoirs of the Life and Writings of Thomas Carlyle (London, 1881).

Smith, Alexander, Last Leaves (Edinburgh, 1869).

Spielmann, M. H., The History of "Punch" (London, 1895).

[Stead, W. T.], "The 'Pall Mall Gazette," Review of Reviews, VII (February 1893), 139-56.

Straus, Ralph, Sala: The Portrait of an Eminent Victorian (London, 1942). 


\section{James Hannay}

Smeaton, Oliphant, The Story of Edinburgh (London, 1905).

Tinsley, William, Random Recollections of an Old Publisher (London, 1900). Vizetelly, Henry, Glances Back Through Seventy Years (London, 1893).

Watson, Aaron, The Savage Club (London, 1907).

Whyte, Frederic, The Life of W. T. Stead (London, 1925).

[Witty, Eleanor], Elizabeth Affleck Wyatt (London [1938]).

Yates, Edmund, His Recollections and Experiences (London, 1884). 


\section{INDEX}

Acre, Palestine, 9, 10

Adam Bede, 79

Administrative Reform Association, 72

Albert, Prince, 35, 126

Albert Edward, Prince of Wales, 126

Alexandra, Princess, 126

Alexandria, Egypt, 9

Allingham, William, 72, 113, 114, 116

All the Year Round: Hannay's contributions to, 68-69

Amadeo, King of Spain, 157, 166

American literature: Hannay's estimate of, 86

Anti-Jacobin, 145

Aristophanes, 132

Arnold, Matthew, 137

Athenaeum, 125, 154; Hannay's contributions to, 65, 85, 91-92; Biscuits and Grog reviewed in, 59; Eustace Conyers reviewed in, 112

Athens, Greece, 13-14

Atlantic Monthly, 92

Austin, W. S., 72, 116

Bagot's Youth, 39, 72

Barcelona, Spain: Hannay's consulship in, 1, 14, 156, 157-63; Hannay's opinion of, $9,160-61$

Barnard, Captain Edward, 7-8

Begg, James, 134, 135, 136, 142-43, 146

Beirut, Lebanon, 9, 11

Benbow, Admiral John, 5

"Benbow school," the, 8, 22

Berkeley, George Charles Grantley Fitzhardinge and Thomas Moreton Fitzhardinge, 29, 35

Biscuits and Grog, 5, 6, 8, 9, 10, 12, 14, 15, $22,23,24,42-46,47,58,59,108$

Blackie, John Stuart, 138-39, 146

Blackwood's Edinburgh Magazine, 71; harsh review of Carlyle's Latter-Day Pamphlets in, 61

Blackwood v. Carlyle, 61-64

Blake, Admiral Robert, 5, 6, 25, 55-56, 67

Blanchard, Edward F., 31, 72, 116

Blanchard, Sidney L., 116

"Blood and culture," 69, 72-73, 111, 128

Bogue, David, 75, 98

Bohemia: Hannay's sojourn in, $39-40$

Book of Snobs, The, 73, 153

Brief Memoir of the Late Mr. Thackeray, A, 148

Bright, John, 128

British Museum Reading Room, 38, 41, $87,97,115$

Brooks, Shirley, 31, 72

Brough, Robert, 31, 71, 116

Brough, William, 116

Brown, Ford Madox, 38; praises Satire and Satirists, 98
Buccleuch Place, Edinburgh, 125

Buckle, Henry Thomas, 79

Burke, Edmund, 128

Burns, Robert: Hannay's estimate of, 102

Byron, George Noel Grordon, Baron: Hannay's defense of, 100

Cannon, Captain Edward St. Leger, 16

Canonbury. See Islington

Carlinwark House, 3

Carlinwark Loch, 3

Carlists, 164, 166

Carlyle, Thomas, $51,79,98,116,128,133$, 150; interest in Hannay, 2, 27; influence on Hannay, 10, 15, 47, 53-56 (Singleton Fontenoy), 64, 67, 69-70, 73 ("Sketches of Radicals"), 74-75 ("Sketches of Radicals"), 77, 102 (Satire and Satirists), 10910 (Eustace Conyers), 112 (Eustace Conyers), 132; Hannay's admiration of, 46, 107; praise of Singleton Fontenoy, 60; praise of Satire and Satirists, 98; conversation reported by Hannay in New York Tribune, 78; praise of Swift as a satirist, 100; Essays from the "Quarterly Review" dedicated to, 148

Carpenter, Mary, 68

Casaubon, Isaac, 68

Chapman, John, 89

Chapman and Hall, 113

Characters and Criticisms, 148-49

Chartists, 29, 32, 35

Cherbourg, France, 69, 117

Churchill, Charles: Hannay's estimate of, 102

Civil Service Gazette, 92-93

Civil War, American: Hannay on, 125, 128-31

Claret-Cup, A, 14, 16, 42-46, 47, 58, 108

Classical scholarship: Hannay's interest in, 37

Cobden, Richard, 128

Cobet, Carel Gabriel, 139

Colburn, Henry, 58-59

Cole, Charlotte, 148

Coleridge, Samuel Taylor, 128

Collingwood, Admiral Cuthbert, 5, 22, 25, 56,67

Collins, Mortimer, 72

Conservatism: Hannay's definition of, 127-28, 133

Cornhill Magazine: Hannay's contributions to, 1, 149, 152, 157, 163

Corunna, Spain, 162

Count of Monte Cristo, The, 33

Course of English Literature, A, 104-08, 149

"Court Martial, The," 18

Covent Garden, 38

Cowell, Samuel Houghton, 33-34 


\section{INDEX}

Crail, Scotland, 157

Crimean War, 76, 77, 78

Critic: Singleton Fontenoy reviewed in, 60; Eustace Conyers reviewed in, 112

Crowe, Joseph Archer, 30, 39, 116

Crystal Palace, 66

Curtis, Rear Admiral Sir Lucius, 18

Curtis, Lieutenant Roger, 18, 19

Daily News, 27; Hannay's contributions to, $82-85$, passim

Dallas, Eneas Sweetland, 146.

"Dante's Dream," 114

Daughter of the Regiment, The, 33-34

David Copperfield, 35

Debating societies: Hannay's interest and participation in, 40

Derby, 14th Earl of (Edward George Geoffrey Smith), 127, 146

Devereux, Captain Walter, 15

Dichtung und Wahrheit, 97

Dickens, Charles, 50, 79, 104, 154; Hannay's estimate of, $29,35,78,84,107$; editorship of Household Words, 67, 68; marital difficulties, 80

Disraeli, Benjamin, 66, 73, 127, 133, 146-47

Dixon, William Hepworth, 67, 125, 154

Dombey and Son, 29

Drury Lane Theatre, 33

Dumfries, Scotland, 3, 96; Hannay a candidate for a parliamentary constituency in, 117-23

Dumfries and Galloway Courier, 3, 4, 120; Hannay's contributions to, 77, 79-81

Edgar; John George, 115-16

Edinburgh, University of, 137, 138, 139, 140

Edinburgh Courant: Hannay's editorship of, 124-44, 146; Hannay's contributions to, 148,149

Edinburgh Town Council, 126, 132-33

Edwards, Henry Sutherland, 27, 28, 30, $31,37-38,72$

Edwards Street Literary Institution, 98

Eliot, George, 146

Elwin, Whitwell, 93

English Humourists of the Eighteenth Century, The: Hannay's work on the notes for, 97-98

"Englishman in Spain, An," 163-67

Erasmus, Desiderius, 152

Erewhon, 50-51

Espinasse, Francis, 39, 155

Essays from the "Quarterly Review," 148

Eustace Conyers, 15, 25, 26, 108, 109-13

Evening Standard: Hannay's obituary in, 2

Ewart, William, M.P., 118, 120, 121, 123

Fleet Street, 31, 38

Fox, Charles James, 85
Free Trade, 66

Gadshill Place, 78

Galloway, Scotland, 3

Garrick Club, 80

Gavarni, Paul, 31

Genealogy: Hannay's interest in, 89-91; his ability to recognize the excesses of its devotees, 112. See also Heraldry

Gibraltar, 9, 11

Gladstone, William Ewart, 127, 140, 146

Gracia (Barcelona), Spain, 164-65

Granville, 2nd Earl (Granville George Leveson-Gower), 162, 163

Great Exhibition of 1851,66

Greece: government of modern, 12, 24

Greenwood, Frederick, 39, 115, 163; as editor of Pall Mall Gazette, 145-46

Griswold, R. W., 95

Gurney family of Norfolk: Hannay's history of, 149

Guthrie, Thomas, 134

\section{Hampstead, 115}

Hannay, David (father of James), 3, 4-5, $38,117,118$

Hannay, David (son of James), 115, 162 , 163

Hannay, Elizabeth (daughter of James), 115,156

Hannay, Elizabeth Affleck (mother of James), 3, 4

Hannay, George (father of Jean), 156

HANNAY, JAMES

Biographical Summary

Introduction. Death, 1; obituary notices, 1-2; retrospect of career, 2

Chap. I (1827-1845). Birth, 3; family background, 3; life at Carlinwark House, 3-4; death of mother, 4; remarriage of father, 4; father's financial ruin, 4; James's education, 5; enters Royal Navy, 5; serves aboard the Cambridge, 7-14; -the Snake, 1416; -the Orestes, 16; -the Formidable, 16-18; discharged to the Ceylon, 18; court-martialed, 18-21; sent back to England, 21

Chap. II (1845-1850). Works on Morning Chronicle, 27; -on Pasquin, 27. 30 ; -on Puppet-Show, 30-38; Bohemian life, 38-40; delight in public speaking, 40; friendship with Pre-Raphaelite circle, 40-41; meets Thackeray, 41; begins reading at British Museum, 41; publication of Biscuits and Grog and A Claret-Cup, 40-41; meets Thackeray, 41; begins reading at British Museum, 41; publication of Hearts Are Trumps, 46; publication of King Dobbs and Singleton Fontenoy, 47; financial returns on first five books, 58-59; critical 
reaction, 59-60; meets Carlyle, 60; defends him against Blackwood's, 61-64

Chap. III (1850-1860). Contributes to Punch, 65-66; - to Household Words, 66-68; - to All the Year Round, 68-69; -to United Service Magazine, 69-70; -to Idler, 70-73; - "Sketches of Radicals" to Press, 73-75; -to Illustrated Times, 75-77; - "London Letters" to New York Tribune, 77-79; and to Dumfries Courier, 79-81; reviews books for daily and weekly papers, 81-85; contributes reviews to Leader, 87-88; - to Westminster Review, 8891; - to Athenaeum, 91-92; -to Quarterly Review, 93-94; edits Poe, 94-96; annotates The English Humourists, 96-98; lectures on satire and satirists, 98-103; writes on English literature for Welcome Guest, 104-08; publishes and republishes various naval sketches, 108; publication of Eustace Conyers, 108; lives in various London bachelor lodgings, 113; birth of natural son, 113-14; courtship of Margaret Thompson, 114; marriage, 11415; life at Pleasant Row, Islington, 115; daily routine, 115; friendships, 115-16; conviviality, 116-17; travels in Scotland and France, 117; Dumfries election campaign, 117-23

Chap. IV (1860-1865). Accepts Edinburgh Courant editorship, 124; sets forth the Conservative position, 12728; writes on American Civil War, 128-31; -on dangers of democracy, 131-33; recognizes need for social and political reform, 133-34; attacks the Free Church, 134-36; - Principal Tulloch, 136-37; -classical teaching at University of Edinburgh, 137-39; Edinburgh Liberal Press, 139-42; general dissatisfaction with Edinburgh, 142-43; resigns Courant editorship

Chap. V (1865-1868). Joins staff of Pall Mall Gazette, 146; bereaved by death of Margaret, 147-48; publication of Essays from the "Quarterly Review," 148; - of $A$ Brief Memoir of the Late Mr. Thackeray, 148; -of Characters and Criticisms, 148-49; -of A Course of English Literature, 149; -of Three Hundred Years of a Norman House, 149; -of Studies on Thackeray, 149; contributes to the Cornhill, Temple Bar, and the North British Review, 152; - papers on "Cads" to Imperial Review, 153-54

Chap. VI (1868-1873). Appointed British consul at Barcelona, 156; marries Jean Hannay, 156; arrival in Barcelona, 157; arduousness of his duties,
157-59; dislike of Spanish life, 159-61; difficulties with Foreign Office superiors, 161-63; bereaved by death of Jean Hannay, 163; contributes to the Cornhill, 163; -letters from "An Englishman in Spain" to Pall Mall Gazette, 163-67; death, 167

Characteristics, Attitudes, and Opinions: See entries under American literature, Barcelona, "Blood and culture," Burns, Byron, Carlyle, Churchill, Civil War, Classical scholarship, Conservatism, Debating societies, Genealogy, Heraldry, Hogarth, Hunt, Macaulay, Marryat, Poe, Richardson, Satire, Shakespeare, Spain, Swift, Thackeray, Tupper

Hannay, James, of Blairinnie (grandfather of James), 3

Hannay, Jean (second wife of James), 15657,163

Hannay, Margaret (daughter of James), 115

Hannay, Margaret Thompson (first wife of James), 114-15, 117; death of, 147-48 Hannay, Patrick (son of James), 115, 163 Hannay, William (brother of James), 4

Hardy, Thomas, 50

Haunted Man, The, 35

Hawthorne, Nathaniel, 78

Haydon, Benjamin, 85

Hearts Are Trumps, 46-47, 58, 108

Heraldry: Hannay's interest in, 37, 66

Highbury, 115

Highgate, 115

High Street, Edinburgh, 135

Hire, Lieutenant Henry, 15-16

History of Civilization in England, 79

H. M. S. Cambridge, 5, 6, 7, 8, 9

H. M. S. Ceylon, 18, 20

H. M. S. Fantome, 21

H. M. S. Formidable, 16, 18, 117

H. M. S. Orestes, 16

H. H. S. Scout, 21

H. M. S. Snake, 14, 15

Hogarth, William: as a satirist, Hannay on, 103

Horace (Quintus Horatius Flaccus), 98, 99, 101, 102

Household Words: Hannay's contributions to, 66-68; imitated in Welcome Guest, 103-04

Howitt, William, 29, 35

Howitt's Journal, 29

Hunt, Leigh, 28, 31, 85; Hannay's estimate of, 79

Hunt, William Holman, 41

Hutton, Richard Holt, 146

Huxley, Thomas Henry, 137

Idler: Hannay's contributions to, 70-73

Illustrated London News, 75, 93 


\section{INDEX}

Illustrated Times, 115; Hannay's contributions to, 75-77, 82-85 passim, 103

Imperial Review: Hannay's contributions to, $153-54$

Irving, Washington, 97

Isabella II, Queen, of Spain, 157

Isle of Wight, 35

Islington, 114

Jeaffreson, John Cordy, 60, 72, 114, 115, 116,155

Jerrold, Douglas, 28, 29, 34, 36

Jerrold, W. B., 72

Juvenal (Decimus Junius Juvenalis), 98, 99,101

Kebbel, T. E., 70, 72, 116

Kew Gardens, 68

King Dobbs, 47-52, 58, 59-60, 108

Kossuth, Lajos, 66

Latter-Day Pamphlets, 60-61

Layard, Austen Henry, 162

Leader: Hannay's contributions to, 85 , $86,87-88$

Lemon, Mark, 34, 36, 78-79

Lever, Charles, 146

Lewes, G. H., 87, 146

Lincoln, Abraham, 129, 130, 131

Lisbon, Portugal, 9

Literary Gazette: Biscuits and Grog reviewed in, 59; Eustace Conyers reviewed in, 112

Lock, Georgiana, 113

Lock, James Maxwell, 113-14

Louis-Philippe, King, 31-32

Macaulay, Thomas Babington: Hannay's animosity toward, 78, 79-80, 107

McCulloch, John Ramsay, 27

Mackay, Charles, 31

Madrid, Spain, 162

Man in the Moon, 28, 34

Marryat, Captain Frederick, 167; Hannay's estimation of, 1

Martin, Theodore, 146

Marylebone Literary Institution, 98

Meadows, Kenny, 114

Mehemet Ali, 9, 10, 56

Men of the Time, The, 113

Minto, 2nd Earl of (Gilbert Elliot), 5

Mormonism, 68

Morning Chronicle, 27

"Mr. Adair's Narrative," 21

Munro, Alexander, 40

Napier, Admiral Sir Charles, 9

Napoleon III, 76, 125, 132. See also Napoleon, Louis

Napoleon, Louis, 32, 66. See also Napoleon III

National Magazine, 93
Nautical Magazine: Biscuits and Grog reviewed in, 59

Ned Allan, 3

Nelson, Admiral Horatio, 5, 25

New York Tribune: Hannay's contributions to, 77-79, 118

Noctes Ambrosianae, 71

North, William, 31

North British Review: Hannay's contributions to, 152

On Liberty, 79

Osgood, Frances, 95

Owen, Admiral Sir Edward, 6, 16, 17, 21

Pall Mall Gazette, 39; Hannay's contributions to, 1, 145-47, 153, 163-67; Hannay's obituary in, 2; founding of, 145; on parliamentary reform, 147

Palmer, William, 76, 77, 118

Palmerston, Henry John Temple, Viscount, $76,118,126,127,128,146$

Pasquin, 27-30, 31, 34, 65, 70, 76

Patmore, Coventry, 116

Patras, Greece, 12, 25

Pendennis, 145

Pillans, James, 137-38

Pleasant Row, Islington, 114, 115

Plug, Percival, 42, 44, 47

Plymouth, Devonshire, 8

Poe, Edgar Allan, 167; Hannay's admiration of and his edition of P.'s Poetical Works, 94-96

Portsmouth, Hampshire, 8, 21, 68

Pre-Raphaelite Brotherhood, 40, 41

Presbyterianism in Scotland, 126, 134-37

Press: Hannay's contributions to, 73-75, 76, 82-85 passim, 153

Punch, 28, 30, 34, 79, 132-33; Hannay's contributions to, 65-66

Puppet-Show: Hannay's contributions to, $31-38,65,70,76$

Puseyism, 53, 66

Quarterly Review, 134; Hannay's contributions to, $65,85,87,93-94,122-23,149$

Reach, Angus B., 28, 36

Read, Thomas Buchanan, 95

Renan, Ernest, 136-37

Rich, Captain George Frederick, 16, 17

Richardson, Samuel: Hannay's low opinion of, 106

Ridge, Hertfordshire, 4, 113, 117

Roebuck, John Arthur, 128

Rogers, Samuel, 85

Rossetti, Christina, 147

Rossetti, Dante Gabriel, 38, 40, 114, 115, 147; praises Satire and Satirists, 98

Rossetti, William Michael, 38, 40, 115

Rousseau, Jean-Jacques, 53

Russel, Alexander, 124, 140, 141, 146 
Russell, Lord John, 32, 65-66, 127

Saintsbury, George, 106

Sala, George Augustus, 71

Sand and Shells, 69, 108

Sanitary reform, 66

Satire: Hannay on, 89, 98-103

Satire and Satirists, 98-102

Scotsman, 124, 140-43

Scott, Sir Walter, 151

Sepoy mutiny, 77

Serrano, General Francisco, 157

Shakespeare, William: Hannay on the proper study of, 105

Sharp, Becky, 149-50

Sheerness, Kent, 5, 8, 52, 117

Singleton Fontenoy, 6, 7, 10, 11, 14, 15, 17, $18,23,41,47,52-58,60,65,108$

Sketches in Ultra-Marine, 108

"Sketches of Radicals," 73-75, 153

Smith, Albert, 28, 34

Smith, George, 145

Smith, Sydney, 85

Smith, Elder \& Co., 98, 145

Southend, Essex, 117, 148

Southey, Robert, 134

Spain: Hannay's assessment of life in, 159-60; Hannay's assessment of her political institutions, 165-67

Spielmann, M. H., 65

Stanley, Edward Henry (later 15th Earl of Derby), 123, 124, 127, 156

Stephen, James Fitzjames, 146

Stephen, Leslie, 146

Stephenson, Harriet, 4

Sterne, Laurence, 151

Stigant, William, 116

Stirling, Robert, 140

Strand, the, 38

Studies on Thackeray, 148, 149-52

Swift, Jonathan: Hannay's admiration of, 100; Hannay challenges Thackeray's view of, 151

Symonds, John Addington, 146

Symonds, Sir William, 15

Tavistock Place, 148

Temple Bar: Hannay's contributions to, 152

Tennyson, Alfred, Baron, 79

Thackeray, Anne, 145, 146

Thackeray, William Makepeace, 50, 51, $73,76,79,116,145$; interest in Hannay, 2, 27, 41, 65; Hannay's estimate of, 29, $35,36,46,82-85,88,91,107,149-52$ (in Studies on Thackeray); admiration of
King Dobbs, 59-60; introduces Hannay to the proprietors of the New York Tribune, 77; subject of an article by Edmund Yates, 80-81; introduces Hannay to the editor of the Quarterly $R e$ view, 93; asks Hannay to supply the notes for The English Humourists, 9697; Hannay disagrees with T.'s view of Swift, 100, 151

Théâtre Historique, 83

Thomas, Annie, 155

Thomas, William Moy, 40

Thompson, Margaret, 114. See also Hannay, Margaret Thompson

Thornbury, G. W., 72, 116

Three Hundred Years of a Norman House, 149

Times, 27, 126

Tom Brown's School Days, 79

Town Talk, 80

Train, $70-71$

Train, Joseph, 68

Trollope, Anthony, 146, 148

Trunnion, Admiral Hawser, 5

Tulloch, John, 136-37

Tupper, Martin: Hannay's scornful reviews of, 91-92

United Service Magazine: Hannay's contributions to, 69-70, 108

Valletta, Malta, 6, 11-12, 45

Vanity Fair, 29, 41

Victoria, Queen, 35

Vizetelly, Henry, 27, 30, 31; founds Illustrated Times, 75; founds Welcome Guest, 103

Welcome Guest, 93, 103-04; Hannay contributes "A Course of English Literature" to, 104-08, 149

Westminster Literary Institution, 98

Westminster Review: Hannay's contributions to, 85-86, 88-91

Whigs, 32

Whittington Club, 29, 35

Wilberforce, Edward, 70, 116

Willis, N. P., 95

Wills, W. H., 68

Wordsworth, Bishop Charles, 143

Worthing, Sussex, 117, 125

Wylde, W. H., 1, 162

Yates, Edmund, 70-71; his role in the Garrick Club controversy, 80-81

Yorkshire Post: Hannay's obituary in, 1-2 